UNIVERSIDADE DE SÃO PAULO

FACULDADE DE FILOSOFIA, LETRAS E CIÊNCIAS HUMANAS

DEPARTAMENTO DE LÍNGUÍSTICA

PROGRAMA DE PÓS-GRADUAÇÃO EM SEMIÓTICA E

LINGUÍSTICA GERAL

EDELSVITHA PARTEL MURILLO

Estudo Toponímico do Parque Estadual Turístico do Alto Ribeira, Petar:

historicidade e etnicidade nos aspectos conceituais dos nomes de lugar

São Paulo

2013 
EDELSVITHA PARTEL MURILLO

\title{
Estudo Toponímico do Parque Estadual Turístico do Alto Ribeira, Petar: \\ historicidade e etnicidade nos aspectos conceituais dos nomes de lugar
}

\begin{abstract}
Tese apresentada ao Programa de Pós-Graduação em Semiótica e Linguística Geral do Departamento de Linguística da Faculdade de Filosofia, Letras e Ciências Humanas da Universidade de São Paulo, para obtenção do título de Doutor em Letras.
\end{abstract}

Orientadora: Prof $^{\mathrm{a}}$. $\mathrm{Dr}^{\mathrm{a}}$. Maria Vicentina de Paula do Amaral Dick

São Paulo

2013 
Murillo, E. P. Estudo Toponímico do Parque Estadual Turístico do Alto Ribeira, Petar: historicidade e etnicidade nos aspectos conceituais dos nomes de lugar.Tese apresentada ao Programa de Pós-Graduação em Semiótica e Linguística Geral do Departamento de Linguística da Faculdade de Filosofia, Letras e Ciências Humanas da Universidade de São Paulo, para obtenção do título de Doutor em Semiótica e Linguística Geral.

Aprovado em:

\section{Banca Examinadora}

Prof. Dr.

Instituição: Assinatura:

Prof. Dr. Instituição: Assinatura:

Prof. Dr. Instituição: Assinatura:

Prof. Dr. Instituição: Assinatura:

Prof. Dr. Instituição: Assinatura: 
Ao Riva, Fabio, Cassio e Marco 


\section{AGRADECIMENTOS}

Agradeço especialmente a minha amiga e orientadora, Professora Dra. Maria Vicentina, pela confiança e pelos ensinamentos preciosos que possibilitaram a realização deste trabalho.

A minha família, em particular meu marido, Rivaldo, e meus filhos, Fabio, Cassio e Marco pelo apoio e incentivo.

A todos os amigos de Iporanga, em especial às Professoras Soraia, Eunice e Milena, ao Seu Arabelo, Seu Joaquim Justino, Jurandir e Alberto, pelas informações preciosas que compartilharam em minhas visitas ao Petar.

À Professora Dra Sandra Keppler pelas sugestões e conversas produtivas que auxiliaram a feitura do trabalho.

Ao Professor Dr. Clayton Lino, que disponibilizou seu tempo precioso em conversas importantes que ajudaram a fundamentação desta pesquisa.

À Universidade de São Paulo e seus professores pela oportunidade em dar continuidade a meus estudos.

Ao ITESP, Fundação Instituto de Terras do Estado de São Paulo, por disponibilizar material valioso que muito contribuiu para a realização deste projeto.

À Banca de Qualificação, formada pelos Profs. Drs. Maria Aparecida Barbosa e José Alcides Ribeiro. Pela leitura atenta e sugestões. 


\section{RESUMO}

MURILLO, E. P. Estudo Toponímico do Parque Estadual Turístico do Alto Ribeira, Petar: historicidade e etnicidade nos aspectos conceituais dos nomes de lugar. Tese (Doutorado) - Faculdade de Filosofia Letras e Ciências Humanas, Universidade de São Paulo, São Paulo, 2013.

A região do Vale do Ribeira, ao sul do Estado de São Paulo, abriga a maior concentração de remanescentes de Mata Atlântica do Brasil. O Parque Estadual Turístico do Alto Ribeira, Petar, entre os municípios de Iporanga e Apiaí, representa parte significativa desse bioma. Inserida nesse ambiente de mata preservada existe uma população que luta pelo resgate de sua história e identidade étnico-cultural. A nomenclatura toponímica, objeto desta pesquisa, determina significações atribuídas pelos grupos humanos que ocupam ou ocuparam a região configurando territorialidades específicas marcadas, principalmente, pelas comunidades rurais: grupos quilombolas que vivem na região desde os primórdios da colonização e pequenos agricultores que trabalham a terra para garantir a subsistência de sua família e da comunidade. Há, ainda, uma pequena comunidade urbana constituída, principalmente, por antigos moradores bastante identificados com as especificidades do lugar assim como grupos mais recentes ligados às atividades de pesquisa, turismo e espeleologia, grupos estes constituídos em função do Petar. Optou-se pela análise dos nomes de lugar levando-se em consideração as camadas toponímicas fundamentadas na historiografia da região, posto que as camadas explicariam as relações que, em diferentes épocas, o homem manteve com o lugar, pontuando interações importantes da população local com o ambiente: a primeira camada é marcada pela comunidade indígena que ocupava a região antes da chegada dos colonizadores europeus; a segunda está relacionado à chegada dos colonizadores, está implícita, nesse contexto, a comunidade negra que é decisiva na conquista dos territórios do Alto Ribeira, e a terceira relacionase à nova configuração da região como área de preservação ambiental e a constituição das Unidades de Conservação. As alterações ocorridas no espaço espelham as modificações que aconteceram na estrutura socioeconômica da comunidade e, consequentemente, estão refletidas na relação significante/significado do signo toponímico. Nesse sentido, o topônimo seria um elemento importante na constituição do conceptus do lugar. Seguiu-se a metodologia do Projeto ATESP, coordenado por Dick (1999), que tem por objetivo definir as origens dialetais e motivadoras das ocorrências toponomásticas do Estado de São Paulo. O Plano de Manejo do Parque Estadual Turístico do Alto Ribeira-Petar foi a base para 0 levantamento dos topônimos. Os dados históricos foram coletados em livros de vários autores, na prefeitura de Iporanga e, principalmente, em trabalhos acadêmicos desenvolvidos em universidades. Além disso, para que se pudesse compreender a complexidade do entorno do Petar, várias visitas ao local foram realizadas.

Palavras-chave: Petar; Vale do Ribeira; Toponímia; Metáfora; Metonímia. 


\begin{abstract}
MURILLO, E. P. Toponymic Study of Tourist State Park of Alto Ribeira, Petar: Historicity and Ethnicity on Conceptual aspects of Place Names. Dissertation (Ph.D.) - Faculdade de Filosofia Letras e Ciências Humanas, Universidade de São Paulo, São Paulo, 2013.

Vale do Ribeira region, southern São Paulo, has the largest concentration of remaining Atlantic Forest of Brazil. Alto Ribeira Tourist State Park, Petar, between the municipalities of Iporanga and Apiaí represents a significant part of this biome. Inserted in this preserved forest environment there is a population who fights for the recovery of its history and ethnocultural identity. Toponymic nomenclature, object of this research, determines meanings assigned by groups of people who occupy or occupied the region, setting specific territorialities marked mainly by rural communities: Maroons groups living in the region since the early days of colonization and small farmers who work the land for ensure the survival of their family and community. There is also a small urban community mainly consisting of ancient residents heavily identified with place specifics as well as newer groups linked to research activities, tourism and speleology, such groups constituted because of Petar. We decided for the analysis of place names taking into account toponymic layers grounded in the historiography of the region, since these layers explain the relations at different times man had with the place, drawing attention to important interactions of local population with the environment. The first layer is marked by the indigenous community who occupied the region before the arrival of European settlers; the second is related to the arrival of settlers, and has implicit the African community, decisive in the conquest of Alto Ribeira territories; the third is about the new configuration of the region as an area of environmental preservation and the establishment of Protected Areas. Changes in the space reflect the changes that happened in the socioeconomic structure of the community, consequently appearing in the signifier/signified relation inside the toponymic sign. In this regard, Toponym would be an important element in the constitution of the conception of the place. It was followed ATESP Project methodology, coordinated by Dick (1999), which aims to define dialectal origins and motivating occurrences in Toponomastics in São Paulo State. The Management Plan for Alto Ribeira Tourist State Park - Petar - was the basis for toponymic survey. Historical data were collected in various authors' books, in Iporanga City Hall, and especially in academic papers developed at universities. Furthermore, so that one could understand the complexity surrounding the Petar, it was done several visits to Petar.
\end{abstract}

Keywords: Petar; Vale do Ribeira; Toponymy; Metaphor; Metonymy. 


\section{SUMÁRIO}

1. INTRODUÇÃO

2. UNIVERSO DA PESQUISA ................................... 18

3 FUNDAMENTOS TEÓRICOS ............................... 94

4. ESTABELECIMENTO DO CORPUS DE ANÁLISE. METODOLOGIA .......................................................136

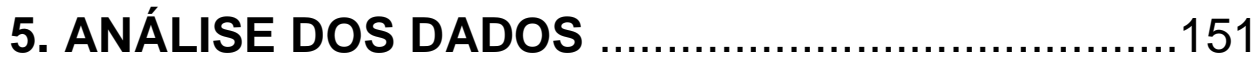

6. CONSIDERAÇÕES FINAIS .................................. 229

7. REFERÊNCIAS BIBLIOGRÁFICAS ..................... 236

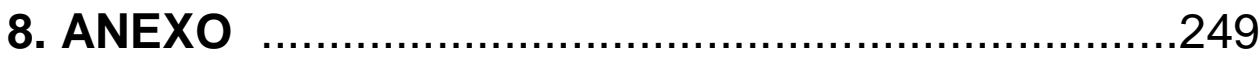




\section{ÍNDICE}

1. INTRODUÇÃO

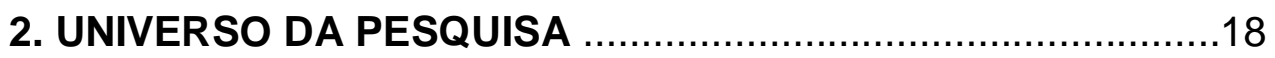

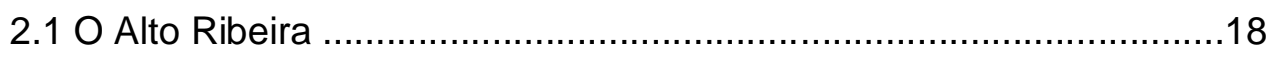

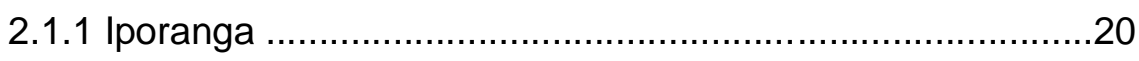

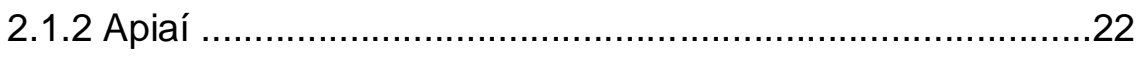

2.2 Retrospectiva histórica do recorte observacional: Petar como foco da

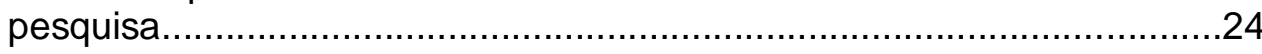

2.3 Comunidades quilombolas do entorno do Petar ................................4

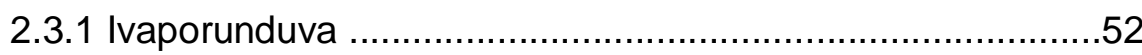

2.3.2 Maria Rosa e Pilões ............................................................56

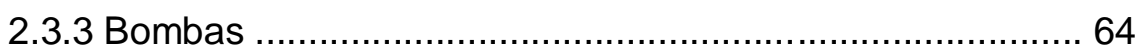

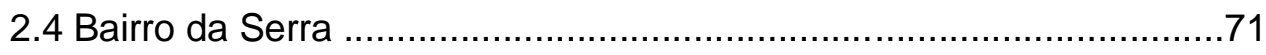

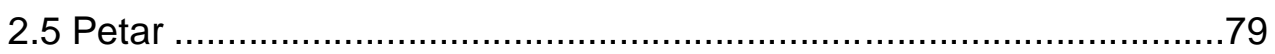

2.5.1 Análise da estrutura denominativa do Petar ........................86

3 FUNDAMENTOS TEÓRICOS ……………………...................

3.1 A base do Triângulo de Ogden \& Richards ........................................94

3.2 Aspectos denotativos do signo toponímico, o modelo Dick ...............99

3.3 Aspectos conotativos do signo toponímico …………………….......106

3.4 O conceptus do nome próprio de lugar em uma abordagem metafórica e metonímica ........................................................................114

4 ESTABELECIMENTO DO CORPUS DE ANÁLISE.

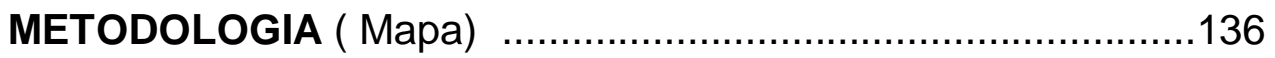

4.1 Metodologia do Projeto ATESP ………………………………........137

4.1.2 O Projeto ATESP ………………………………….....140

4.1.2.1 Taxionomias Toponímicas .................................143

4.2 Delimitação do espaço .................................................................147

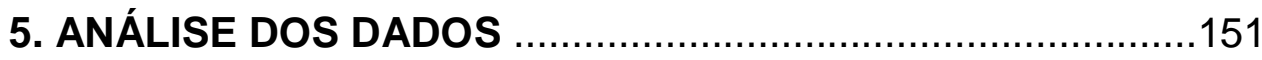




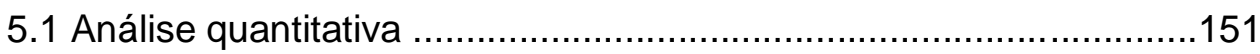

5.1.1 Apresentação do corpus de análise ...............................152

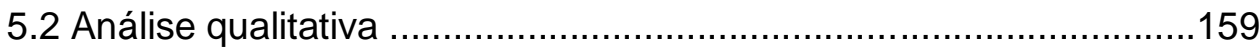

5.2.1 Percurso de análise do corpus .......................................159

5.2.2 Denominativos de origem tupi .........................................160

5.2.3 Miscigenação étnica do Alto Ribeira ................................182

5.2.4 A implantação do Petar, nova configuração do espaço ....200

5.3 A preservação como o paradigma do entorno do Petar ...................222

6. CONSIDERAÇÕES FINAIS ..............................................229

7. REFERÊNCIAS BIBLIOGRÁFICAS ..............................236

8. ANEXO A Plano de Manejo do Petar...................................249 


\section{Introdução}

A região do Alto Ribeira, ao sul do Estado de São Paulo, caracteriza-se por abrigar os maiores remanescentes de Mata Atlântica preservada do Estado. O Parque Estadual Turístico do Alto Ribeira, Petar, é parte desse bioma e constitui-se em uma das mais antigas Unidades de Conservação do Estado de São Paulo. A principal atração do Petar, além da vegetação exuberante, é seu rico patrimônio espeleológico, considerado um dos maiores do Brasil.

No sentido de colaborar com o Atlas Toponímico do Estado de São Paulo, ATESP, conduzido pela Professora Doutora Maria Vicentina de Paula do Amaral Dick, foi escolhida a região do Alto Ribeira entre os municípios de Iporanga e Apiaí onde está localizado o Petar, em razão das singularidades que caracterizam a ocupação daquele território. Estabelecer as relações entre os traços étnico-culturais das comunidades locais e a nomenclatura toponímica configura um dos objetivos desta tese, tendo por base a análise linguística e histórico-semântica dos denominativos de lugar.

A implantação do Petar trouxe mudanças expressivas nas relações do homem com o lugar. A região conta com uma historiografia antiga, antes mesmo da chegada dos europeus à região, por volta do século XVI. Cada ciclo de ocupação deixou marcas significativas na estrutura denominativa do lugar. Analisar a nomenclatura sob a perspectiva diacrônica, em camadas linguísticas, sustenta a hipótese levantada nesta tese de que as novas configurações determinadas por grupos que se sobrepõem no tempo, significam mudanças na relação significante/significado do signo toponímico, o que implica em novas conceitualizações do 
espaço ocupado. Tais transformações refletem não só a estrutura da sociedade constituída, mas, também, a visão de mundo do grupo, suas ideologias, religiosidade, avanços tecnológicos etc.

Our everyday life consists of concrete "phenomena". It consists of people, of animals, of flowers, trees and forests, of stone, earth, wood and water, of towns, streets and houses, doors, windows and furniture. And it consists of sun, moon and stars, of drifting clouds, of night and day and changing seasons. But it also comprises more intangible phenomena such as feelings. This is what is "given", this is the "content" of our existence (NORBERG-SCHULZ, 1980, p. 6).

A abordagem conceitual do nome de lugar baseou-se, inicialmente, na proposta de Norberg-Schulz de que o espaço só se torna lugar quando o homem consegue se orientar e se identificar nele, isto é, quando o lugar torna-se significativo. Entende-se que a identidade humana está, em larga medida, em função do lugar e das coisas.

O ato de dar nome é a mais simbólica das apropriações do espaço, tornando-o lugar. A intersecção entre a abordagem conceitual do lugar e a abordagem conceitual do topônimo se deu baseado nas propostas de Lakoff e Johnson (1980) que afirmam que a maneira como se pensa e atua é fundamentalmente de natureza metafórica. O espaço é concebido metaforicamente como um recipiente, um continente, que abarca um conteúdo, uma substancia, ou, então, é concebido como uma entidade, podendo, ainda, ser especificado como uma pessoa. Entende-se a metonímia como parte desse processo também, ou seja, conceitualizar uma coisa em virtude de sua relação com outra, buscando a compreensão. Os autores apresentam três tipos de conceptus metafóricos: metáforas de orientação ( acima/abaixo), metáforas 
ontológicas ( entidade, substancia e recipiente) e metáforas estruturais ( discussão é uma guerra).

A ocupação humana do Vale do Ribeira remonta ao período pré-colombiano, consta que a área era rota de passagem para os índios do planalto que desciam, no inverno, para o litoral em busca de pesca (PETRONE, 1966). As condições geográficas do Alto Ribeira foram favoráveis como zona de refúgio para os índios perseguidos pelo bandeirantismo escravagistas. Essa população deixou marcas na formação dos contingentes populacionais da região tais como técnicas de pesca, agricultura itinerante e a toponímia regional.

A partir do século XVI, com a descoberta de ouro, dá-se início a criação dos primeiros núcleos populacionais. Iporanga, Ivaporunduva, Xiririca e Apiaí são os primeiros povoados criados Ribeira acima. No início do século XVII, chegam os primeiros negros escravos para trabalhar nas frentes de mineração que se expandiam para o interior.

A decadência da mineração favoreceu certo incremento da agricultura, a região passou a produzir cana, mandioca, café, feijão, milho, fumo, ocupando a mão de obra escrava na lavoura. A partir de 1808, com a chegada da Família Real, a região do Vale do Ribeira desenvolve a agricultura do arroz, tornando-se sua grande produtora.

Iporanga e Xiririca se beneficiaram de sua localização às margens do Ribeira de Iguape que permitia a via fluvial como transporte de mercadorias e passageiros. Em Iporanga, até meados dos anos de 1960, o rio ainda era uma via importante de locomoção para os moradores.

A formação dos bairros rurais, característico da configuração da estrutura espacial da região, confunde-se com a história de 
ocupação do Vale do Ribeira. Começam como capuavas de domínio familiar que se expandem em razão do aumento da família, dos laços de amizade e compadrio.

A região caracteriza-se por concentrar o maior número de comunidades quilombolas do Estado de São Paulo, conhecidas por bairros negros rurais, compartilhando das mesma gênese de ocupação da região. Tem-se que, até a promulgação da Constituição Federal de 1988, a origem étnica dessa população não era relevante. A Carta Magna, em seu artigo 68, garantiu aos remanescentes das comunidades quilombolas a propriedade definitiva de suas terras, desde então, lutam pela propriedade da terra e pelo reconhecimento de sua identidade cultural.

A implantação do Petar na década de 1980 transformou a estrutura espacial da região. O lugar que antes era roça, ou bairro rural, passou a ser área de preservação ambiental, impedindo as atividades ligadas à agricultura, criação de animais ou 0 extrativismo vegetal e mineral, práticas comuns na região. $O$ morador tradicional, o caipira, o ribeirinho, o quilombola, deixa de ser a figura central, aquele que tem a posse do território e, portanto, dá nome ao lugar; novas personagens surgem: o pesquisador, o espeleólogo e o turista. A ação denominadora passa, então, a ser deles. Portanto, ao mudarem as relações do homem com 0 território, os focos referenciais também mudam.

O contexto histórico delineou a análise dos denominativos de lugar em três camadas que refletem as diferentes concepções do espaço. A primeira camada refere-se à ocupação pré-cabralina do espaço, ou quando a população indígena e a língua indígena ainda exerciam papel protagonista no ato de nomear. A segunda camada refere-se à chegada do europeu e do negro africano à região. É um período longo que vai do início do século $\mathrm{XVI}$ até o final do século 
XIX. Essa fase é marcada especialmente pela formação dos bairros rurais. A terceira camada comporta a criação das Unidades de Conservação no Alto Ribeira, especialmente a criação e implantação do Petar.

As transformações do território refletem-se na estrutura denominativa. Além das cartas geográficas e do levantamento historiográfico, as relações da população com o lugar são importantes na descrição do objeto topônimo.

Sendo assim, a tese está dividida em sete capítulos:

Esta introdução onde se apresentam os fundamentos que norteiam a pesquisa e a estrutura do trabalho.

O segundo capítulo explicita o universo físico da pesquisa em uma abordagem sincrônica e diacrônica. Sob a perspectiva sincrônica descreve-se o espaço geográfico da região do Alto Ribeira, objetivando contextualizar e justificar a área delimitada. Nesse sentido, justifica-se a importância do rio Ribeira de Iguape na configuração do território como principal caminho de penetração serra acima onde estão localizados os municípios de Iporanga e Apiaí, cidades que compõem a área do Petar.

Sob o ponto de vista diacrônico, acompanha-se o percurso de ocupação da região desde antes da chegada dos europeus até a implantação do Parque. O Vale do Ribeira comporta os mais importantes extratos da formação étnica da sociedade brasileira: o índio, o português e o negro africano. Pelo isolamento e baixo desenvolvimento econômico que se apresentou por muito tempo, a região manteve preservada, além da Mata Atlântica, um modo de vida em suas comunidades representativo de um passado histórico importante para a formação e que deve ser resgatado para que não se perca. Os topônimos são objetos culturais importantes nesse 
resgate, pois, como fósseis linguísticos, possibilitam a reconstrução de aspectos significativos desse passado histórico.

O terceiro capítulo descreve o signo toponímico como objeto de estudo da linguística em uma abordagem semântica. São quatro subtítulos os quais descrevem o percurso de geração se sentido do topônimo contextualizado no tempo e no espaço: 1. A base do triângulo de Ogden \& Richards, onde se justifica o toponímico no universo lexical como palavra-ocorrência que, no ato de nomear, sofre restrição semântico-sintática e passa a ter valor monossemêmico, fazendo que a linha antes pontilhada, ligando nome ao referente, passe a se uma linha contínua. 2. Os aspectos denotativos do signo toponímico, o modelo Dick. Descreve-se o topônimo como objeto de análise do Projeto Atesp inserido no modelo descrito por Dick. 3. Os aspectos conotativos do signo toponímico que analisam o topônimo do ponto de vista do sentido, isto é, contextualizado no tempo e no espaço e, portanto, reflexo da visão de mundo do grupo ao qual se refere. 4. O conceptus do nome próprio de lugar em uma abordagem metafórico-metonímica, além do sentido, que pressupõe a visão de mundo do grupo, o topônimo significa, ou dá significado às relações do homem com o espaço definido como lugar. O topônimo seria um aspecto importante da conceitualização do homem ao lugar.

O quarto capítulo descreve o corpus de análise e explicita a metodologia do Projeto Atesp, organizado por Dick. A motivação toponímica delimitada por meio das taxionomias toponímicas definem o objetivo do Projeto que é o de buscar as tendência motivadoras da toponímia paulista.

O levantamento do corpus teve como base duas cartas geográficas fornecidas pelo Petar: (1) Plano de Manejo do Parque Estadual Turístico do Alto Ribeira - Petar, Ocupação Humana do 
Interior do Entorno, em escala numérica de 1:250.000. (2) Plano de Manejo do Parque Estadual Turístico do Alto Ribeira - Petar, Zona de Amortecimento, em escala numérica de 1:100.000.

O mapa do IBGE do município de Iporanga serviu como base de apoio por englobar a toponímia de toda a região - Mapa Municipal Estatístico, Iporanga-SP, em escala numérica de 1:50.000.

A pesquisa de campo complementou a nomenclatura coletada nos mapas, justificando a abordagem conceitual do nome próprio de lugar que pressupõe a interação do homem com o lugar, interação física e/ou simbólica.

O quinto capítulo apresenta a análise dos dados; do ponto de vista quantitativo levou-se em consideração as taxionomias toponímicas e o Projeto Atesp. Do ponto de vista qualitativo, optouse pela descrição dos denominativos em camadas, levando-se em conta a historiografia e a motivação toponímica. Tem-se que a concepção do espaço tornado lugar reflete a visão de mundo de cada ciclo de ocupação. Os aspectos conceituais do nome de lugar espelham essa visão de mundo.

A inserção do Petar no Projeto Atesp trouxe para o campo dos estudos dos denominativos de lugar questões atuais sobre as relações que o homem mantém com o ambiente. A preservação ambiental e o uso sustentável do solo são temas importantes que refletem as mudanças de comportamento na interação do homem com o espaço. Paralelo à preservação ambiental, há a valorização de práticas tradicionais que, além de preservarem valores étnicos /culturais de sua população, resgata uma parte da história que não deve ser perdida. 


\section{O universo da pesquisa}

\subsection{O Alto Ribeira}

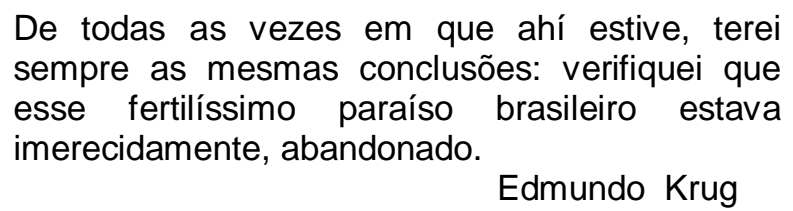

Definiu-se a área de pesquisa na região do Alto Ribeira, especificamente no Petar, Parque Estadual Turístico do Alto Ribeira. A escolha se deu após uma visita ao Parque e à importância que o contato direto com a Mata Atlântica em seu estado quase virgem despertou. Entrar em uma caverna é uma experiência única, o Petar é conhecido pelo grande número de cavernas em seu entorno, todas devidamente denominadas.

Como pesquisa de nomes de lugar, os topônimos, não se poderia descartar as possibilidades que a região oferecia ao grupo de pesquisa, o Projeto ATESP, conduzido por Dick. A dicotomia natureza e cultura, um dos focos da presente pesquisa, está explicitada na região do Petar, particularmente nas relações das comunidades tradicionais, pequenos agricultores e quilombolas, e a implantação do Parque como Área de Proteção Ambiental (APA). Essa situação, por vezes conflituosa, marcará parte desta trajetória, visto que o homem, aquele que denomina e, por isso, detém o domínio do território, é o principal protagonista desta pesquisa.

A região do Alto Ribeira, parte da região do Vale do Ribeira, uma das mais pobres economicamente do Estado de São Paulo, é constituída principalmente por comunidades tradicionais, especialmente comunidades quilombolas, que ocupam a região desde os primórdios de sua colonização. Há quem afirme que a 
essas comunidades deve-se a preservação ambiental da região. Carril (1995) afirma que a prática de uma agricultura de subsistência e o isolamento geográfico representado pela Serra do Mar teria impedido o desenvolvimento de grandes atividades agrícolas e, com isso, mantido a natureza quase em seu estado natural.

Localizado ao sul do Estado de São Paulo, o Vale do Ribeira, banhado pelo rio Ribeira do Iguape, é uma área de grande extensão que comporta a Bacia Hidrográfica do rio Ribeira do Iguape e o Complexo Estuarino Lagunar de Iguape, Cananeia e Paranaguá. O Ribeira do Iguape nasce pela confluência dos rios Ribeirinha e Açungui, no Paraná, a noroeste da região metropolitana de Curitiba a uma altitude de aproximadamente 1.000 metros. Seu curso é de $520 \mathrm{~km}$ em direção ao sul de Estado de São Paulo, desaguando no mar na cidade de Iguape; sua largura varia de 100 a 120 metros, estreitando-se em gargantas de 40 a 50 metros, onde são formadas as corredeiras pedregosas ${ }^{1}$.

A área paulista margeada pelo rio ocupa $10 \%$ do território do Estado e conta com a maior extensão de floresta Atlântica de São Paulo, cerca de $60 \%$ de sua área.

O Vale do Ribeira pode ser subdividido em três sub-regiões de acordo com suas características econômicas e geográficas:

- Alto Vale, mais montanhoso e isolado. Abriga os municípios de Apiaí, Ribeira e Iporanga.

- Médio Vale, configura o trajeto da Rodovia Régis Bittencourt (BR 116), que liga São Paulo a Curitiba. É nele que se encontra a maior cidade do Vale,

\footnotetext{
1 Pereira de Queiros apud Negros do Ribeira: Reconhecimento étnico e conquista do território. Cadernos do Itesp 3, p 59, 2000.
} 
Registro; compreende também os municípios de Eldorado, Jacupiranga, Pariquera-Açú e Sete Barras.

- Baixo Vale, é a região litorânea do vale; compreende os municípios de Cananéia e Iguape.

Natureza exuberante e riquezas naturais contrastam com o título de região que detém um dos menores índices de IDH do Estado de São Paulo. Mais da metade do território do Vale do Ribeira é protegido legalmente por meio de Unidades de Conservação marinhas e terrestres, tais como parques, estações ecológicas, áreas de proteção ambiental (APAs). É essa barreira natural que contribui para que se preservasse, quase intacta, a natureza, o patrimônio socioambiental, a cultura, a arqueologia, as cavernas e aspectos relevantes da etnografia da população local.

Em 1999, o título de Patrimônio Natural da Humanidade foi conferido pela UNESCO ao Vale do Ribeira, em razão de seus 2,1 milhões de hectares de florestas, $21 \%$ dos remanescentes de Mata Atlântica de todo o País, 150 mil hectares de restingas e 17 mil de manguezais.

\subsubsection{Iporanga}

Concentrou-se a base de estudos na cidade de Iporanga, onde está localizada a maior porção do Petar. É ali, também, que foi contatada a população que vive ou interage diretamente com o Parque.

Iporanga é topônimo de origem indígena tupi $(y>$ rio, poranga > bonito), nome dado ao rio afluente do Ribeira, atualmente ribeirão Iporanga, onde surgiu o primeiro núcleo 
habitacional, o Garimpo de Santo Antonio, que deu origem, mais tarde, à cidade de Iporanga.

Iporanga está localizada ao sul do Estado de São Paulo, a uma distância de aproximadamente $360 \mathrm{~km}$ da capital, nas latitudes S.24 35'04" e longitude W GR 48 . Situa-se na subzona geomorfológica da Serra de Paranapiacaba, no complexo que forma a Serra do Mar, no coração da Mata Atlântica, junto às margens do rio Ribeira de Iguape, e na foz do Ribeirão Iporanga, abrangendo uma área de $1.152 \mathrm{~km}^{2}$. Predomina na região o clima subtropical úmido com média de temperaturas em torno de $18^{\circ} \mathrm{e}$ precipitação anual podendo atingir até $4.000 \mathrm{~mm}$.

Em 2010, contava com uma população de aproximadamente 4.210 habitantes. Interessante notar que em 2007 dados do IBGE ${ }^{2}$ mostram que a população de Iporanga era de 4507; e, em 1996, 4715; verificou-se, portanto, uma tendência de decréscimo populacional, invertendo uma tendência de aumento que acompanhava as do Estado de São Paulo; uma das razões talvez seja a falta de perspectiva dos mais jovens em relação à sua formação profissional e às possibilidades de trabalho na região, que não são muitas, prevalecendo o trabalho na área rural, ou os serviços ligados ao turismo do Petar.

A cidade é conhecida por Capital das Cavernas, devido ao grande número de cavernas calcarias em seu entorno, em especial no Petar. Estão cadastradas aproximadamente 360 cavernas, número que a coloca como município com o maior número de cavernas do Brasil e, talvez, do mundo.

Atualmente, sua economia é dependente do turismo gerado pelo Petar. O valioso patrimônio natural, composto por sítios espeleológicos, paleontológicos, arqueológicos e históricos, além

${ }^{2}$ IBEGE Cidades, 2010 http://www.ibge.gov.br/cidadesat/topwindow.htm? 
da grande diversidade biológica característica da Mata Atlântica preservada em toda sua extensão, é, nos tempos atuais, o maior valor econômico da cidade. Cinquenta por cento do território de Iporanga está ocupado por Parques Estaduais.

\subsubsection{Apiaí}

Apiaí está localizada no Alto Ribeira, a oeste de Iporanga,

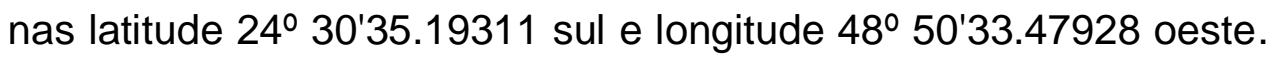
Sua área territorial é de 974,322 km² $^{2}$ contado com uma população de aproximadamente 25.191 habitantes $^{3}$. O clima predominante é o subtropical, temperado/super-úmido.

Esta cidade insere-se no contexto espacial por incorporar parte do Petar. Além da riqueza ambiental configurada principalmente pelo entorno do Parque, a cerâmica do município é tida como uma das mais representativas do país. Apiaí, cujo nome decorre do tupi, "Piá-Y", que significa "rio menino", acepção oficial adotada pela prefeitura, abrangia por ocasião de sua formação um extenso território dos atuais municípios de Ribeira e Iporanga.

O povoamento da região de Apiaí iniciou-se com as incursões mineradoras dos bandeirantes que deixaram vestígios até hoje nos topônimos locais, rios e elevações. Relatos históricos sugerem que Brás Cubas, o fundador de Santos, com Luiz Martins, ainda no século XVI, teriam descoberto o ouro de lavagem em Apiaí.

Segundo Mancebo $(2001)^{4}$, pesquisador da história de Apiaí, aventureiros subiram as correntezas do rio Ribeira e seus afluentes, já no século XVI, até um local denominado Porto de Apiahy, naquela região o metal era encontrado em abundância. $O$

\footnotetext{
${ }_{4}^{3}$ Dados do IBGE referentes ao ano de 2010.

4 Mancebo, O. Apiaí; do sertão à civilização: história regional, Apiaí no Alto Ribeira e arredores. São Paulo, 2001.
} 
volume de garimpeiros aumentou muito, formando um primeiro povoado em Vila Velha do Peão, ao norte do Morro do Ouro, onde havia igreja, cemitério e construções de taipa e terra batida. Com o esgotamento do ouro nessa região houve o deslocamento para a região do Morro do Ouro, por volta de 1770. Formou-se, então, um segundo povoado cuja população constava de negros, índios e brancos.

O fundador oficial do município foi o Capitão Mor, Francisco Xavier da Rocha; obrigado a fugir de Minas Gerais por ter praticado crime, chegou à região com 150 escravos em sua comitiva, fixou-se entre os ribeirões Palmital e Água Grande, na Serra de Paranapiacaba, local onde se originou o povoado de Vila de Santo Antonio das Minas de Apiahy.

Em 25 de agosto de 1892, passa a comarca e em 19 de dezembro de 1906 obteve o foro de cidade, cujo nome reduziu-se à Apiahy.

Apiaí conta com uma economia bastante dinâmica, muito diferente do município de Iporanga; não depende do turismo apesar de fazer parte da maior reserva de Mata Atlântica do país e estar na região declarada pela UNESCO como "Reserva da Biosfera do Patrimônio Mundial".

Por Apiaí passa o trecho sul do gasoduto Brasil/Bolívia e as linhas de energia da Furnas Centrais Elétricas S.A. Também está instalada na cidade, desde 1975, a Camargo Corrêa Cimentos, responsável pela demanda de cimento da região sul do país. Conta com os seguintes recursos minerais: galena, calcário, quartzo, cobre, manganês, granito e cal. 


\subsection{Retrospectiva histórica do recorte observacional: Petar como foco da pesquisa}

Quem controla o passado controla o futuro.

George Orwell

Com vistas a situar na presente tese, será feita uma retrospectiva histórica do Vale do Ribeira, local onde se localiza o Petar, a fim de melhor caracterizá-lo e mostrar sua importância e relevância.

Tem-se registro de sua historiografia desde o período précolombiano, sendo a região do Ribeira uma área de passagem para os povos indígenas que desciam do planalto para o litoral no inverno em busca de pesca. No entanto, estima-se que ela era habitada por contingentes pouco numerosos. Embora os dados variem significativamente, é certo que a faixa sublitorânea não era um vazio demográfico, em especial antes da chegada dos primeiros colonizadores. Era uma população de canoeiros que pescavam e coletavam mariscos, com o rio, como não poderia deixar de ser, como a principal ligação entre o litoral e o planalto. O litoral sul até Ubatuba e o planalto representavam uma grande faixa de terra habitada pelos Guaianás e, ao sul de Cananéia, viviam os Carijós (PETRONE, 1966, p.69).

Em seu livro, Prezia ${ }^{5}$ problematiza a questão dos Guaianás do sudeste. A polêmica se deu em torno de duas teses. A tese da tradição histórica, liderada por Capistrano Abreu e, posteriormente, apoiada por Teodoro Sampaio e Washington Luis, que afirmava serem os Guaianás do Planalto do tronco macro-gê. Já o grupo

${ }^{5}$ PREZIA, Benedito A. Os indígenas do Planalto Paulista, capítulo IV, p. 179, 2010. 
liderado por Afonso de Freitas e Plínio Ayrosa apoiava a tese da tradição paulista a qual afirmava serem os Guaianás moradores de Piratininga e da cultura tupi.

Pesquisadores modernos, entre eles Dick $^{6}$, abandonaram a polêmica e continuam afirmando a tese paulista de que o grupo pertenceu à cultura tupi. Essa discussão é bastante pertinente no universo dessa pesquisa, pois se trabalhou com topônimos que datam do período pré-colonial e, portanto, com etimologias, muitas vezes complexas, que apresentam certa dificuldade de serem interpretadas. A esse respeito, outras possibilidades podem ser úteis para decifrar etimologias que apenas com o tupi não seriam plenamente compreendidos seus significados.

De acordo com Petrone (1995, p. 31), seria possível inferir que havia três grupos vivendo em terras paulistas: (1) os Tupinambás, que viveriam na porção ao norte de São Sebastião; (2) os Tupiniquins, vivendo na zona entre São Sebastião e Cananéia; (3) os Carijós que se disporiam na área sul de Cananéia.

Plínio Ayrosa (apud PETRONE, 1995, p. 31) afirma que o grupo Tupiniquim, sob a tradicional denominação de Guaianá, estaria dividido em três frações:

(...) a dos Guaianás propriamente ditos, que ocupariam a porção central da área de nosso interesse, o Alto Ribeira, desde o litoral até o sertão, passando pela zona onde surgiram Santo André e São Paulo; a dos Guaianá-Tupinaqui, disposta ao sul, até a zona de Cananéia e, finalmente, a dos Guaianá-Muiramoni, pelo vale do Paraíba e faixa litorânea até a zona de Ubatuba.

Segundo o mesmo autor, essas três frações formariam um grande grupo amigo que, juntando suas forças, teriam condições de enfrentar os Carijós ao sul e os Tamoios (Tupinambás) ao norte.

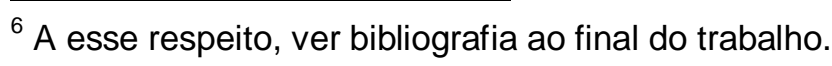


A fronteira entre os Tupis e os Carijós, segundo Schaden (apud PREZIA, 2010, p.166), muito provavelmente se daria no Salto Grande, no Paranapanema, devido ao topônimo Paranitu (Salto Grande) nome de aldeia.

Gonzalez, jesuíta da Província do Paraguai que vivera na redução de San Ignacio de Paraná, às margens do Paranapanema, fala da existência de grupos tupis, chamados Paraná, posteriormente denominados de Temiminó (PREZIA, 2010, p. 167).

No corpus deste trabalho, foi encontrado o denominativo Temimina, como nome de rio, sendo este o denominativo mais antigo, depois, como nome de uma base e duas cavernas do Petar, Temimina 1 e Temimina 2, localizadas no Núcleo Caboclos, próximas à serra de Paranapiacaba, quase na extremidade norte do Petar. Pode-se sugerir que esse denominativo seja autóctone, remanescente da memória de uma ocupação que remonta ao século XVI ou, talvez, antes da chegada dos europeus. A hipótese mais factível remete a um deslocamento de parte do grupo indígena Temiminós de sua área de origem, a Baia de Guanabara, na época em que lutavam com os tupinambás e os franceses. Deslocaram-se, com a ajuda dos portugueses, para a região onde é, hoje, o estado do Espírito Santo, mas nada sugere que não houvera, também, um deslocamento mais ao sul. Ou, mesmo, que esse grupo possa ser o grupo de origem que se deslocara mais ao norte em virtude de lutas com povos inimigos, os carijós ou os guaranis. A história é antiga e não foi descoberto nada que possa comprovar qualquer uma dessas hipóteses além do topônimo apresentado que confirma a passagem do grupo pela região.

A ocupação pré-histórica do Vale do Ribeira pode ser atestada pela grande quantidade de sítios arqueológicos encontrados na região, pesquisados desde o início do século passado (KRONE, 
1914). Para Petrone (1966), a região devia ser pouco povoada e os agrupamentos deviam localizar-se de preferência no litoral e nas margens do rio Ribeira, sendo assim, acredita-se que a região do Ribeira poderia ter conservado suas paisagens naturais quase intactas até a chegada dos europeus.

Nascimento e Sciofoni (2010: 36) ${ }^{7}$ tem uma visão mais complexa em relação à ocupação do vale no período pré-colonial:

A complexidade dos sítios arqueológicos encontrados revelam situações ainda não totalmente desvendadas do ponto de vista cronológico: sambaquis costeiros com uma grande quantidade de sepultamentos sugerem uma densidade demográfica considerável e uma complexidade social muito superior ao anteriormente imaginado. Sambaquis fluviais mais antigos que os costeiros e com semelhante indústria lítica, predominantemente polida e que problematizam questões sobre a relação entre os povos da costa e do interior; sítios arqueológicos da Tradição Umbú, relativo aos grupos caçadores coletores com práticas incipientes de agricultura e com material lítico de grande apuro técnico com a "ponta de flecha"; sítios cerâmicos da Tradição Itararé, grupo que já praticava a agricultura.

As heranças deixadas por essas populações resultaram em um potencial arqueológico extremamente elevado, mas que sofreu grandes perdas desde o início da colonização por serem fontes de exploração de cal para as construções. São evidências de uma ocupação pré-histórica que deixou traços tênues na paisagem que o europeu conheceu ao chegar.

No município de Iporanga foram cadastrados três desses sítios: sítio de Apiaí, localizado na margem esquerda do rio Ribeira do Iguape, no bairro Porto Apiaí; as conchas não são visíveis em

\footnotetext{
${ }^{7}$ NASCIMENTO, F.B.; ET SCIFONI, S. "A paisagem cultural como paradigma para a proteção: a experiência do Vale do Ribeira-SP". In: Revista CPC, São Paulo, n.10, Maio/out., 2010, p.29-28.
} 
superfície e, além disso, foram encontrados poucos materiais líticos lascados e cerâmicas; sítio Inveja, localizado à margem do córrego Inveja, no bairro de mesmo nome, encontra-se mal conservado, em superfície foram encontrados poucos materiais líticos lascados e fragmentos de cerâmica; sítio Anta Gorda, localizado na confluência do ribeirão Anta Gorda com o Ribeira, embora os registros de artefatos cerâmicos cadastrado sejam escassos, pressupõe-se que a continuidade das pesquisas arqueológicas revelem mais detalhes da ocupação de grupos indígenas dos grupos Jê e Tupi-Guarani (DE MARTINI, 2003) ${ }^{8}$.

Já, o entorno de Iporanga possui um rico acervo composto de ruínas históricas originárias dos antigos assentamentos quinhentistas, tanques de lavagem de ouro e construções rurais, algumas das quais resistem até hoje, como os armazéns, casas de farinha, alambiques, senzalas e moendas.

A complexidade da ocupação pré-histórica do Vale do Ribeira pode ser confirmada tendo como base os dados da Comissão Geográfica e Geológica do Estado de São Paulo que afirma que foram localizados vestígios da presença indígena ao longo das margens dos rios Jacupiranga e Batatal, detectados por expedições científicas, assim como no planalto, onde foram encontradas numerosas sepulturas (STUCCHI, 2005).

Pasquale Petrone (1995) refere-se à contribuição dos povos indígenas com respeito à construção da paisagem cultural do Vale do Ribeira como essencial na formação de falares regionais, dos nomes geográficos, os topônimos, de denominativos da fauna, da flora, de instrumentos usados para a caça e para a pesca e dos

\footnotetext{
${ }^{8}$ Tese de Doutoramento apresentada junto ao Programa Interdepartamental de Pós-graduação em Arqueologia-FFLCH/MAE-USP, em dezembro de 2003. O Mito do Paraíso Tropical: caracterização cultural e gerenciamento do patrimônio arqueológico do Parque Estadual da llha do Cardoso.
} 
instrumentos para a produção de farinha de mandioca. Uma maior marca da passagem do indígena ficou, segundo o autor, na população capuava sublitorânea e, especialmente nos caiçaras do litoral; na forma de encarar a natureza, que, de acordo com o ponto de vista do autor, seria uma atitude predatória. Esta pesquisa busca identificar as contribuições deixadas pelas populações por meio dos traços toponímicos, em especial os de origem indígena, e analisar as sucessivas ocupações através dos mesmos topônimos que irá sendo alterado conforme um novo grupo ocupa a área e altera pelo novo nome dado a paisagem local.

A dificuldade de acesso por sua longa cadeia de serras fez da região localizada ao longo do rio Pardo, afluente do rio Ribeira uma importante zona de refúgio para os indígenas. Devido aos obstáculos naturais, a presença dos colonizadores e aventureiros que se estabeleceram como mineradores no rio Ribeira era rara. Também o leito do rio Pardo até a foz do Ribeira era uma região de difícil acesso em razão do grande número de corredeiras e cachoeiras, tornando a subida árdua e demorada. A região do rio Turvo, afluente da margem direita do rio Pardo, parece ter sido intensamente povoada durante o período pré-colombiano e nos primeiros tempos da colonização, recebendo índios fugitivos de Cananéia e da llha do Cardoso, que penetravam pelo rio das Minas, atravessando o sertão do faxinal ${ }^{9}$.

A costa sul do Estado de São Paulo foi uma das primeiras regiões do Brasil a ser povoada logo em sua primeira ocupação. Consta que entre 1502 e 1510 portugueses e espanhóis, degredados ou náufragos, já apresentavam um esboço de povoamento que ia de São Vicente até sítios das futuras povoações

9 Comissão Geográfica e Geológica do Estado de São Paulo, 1914 apud STUCCHI, 2005. 
de Iguape e Cananéia. Já aculturados com os índios nativos, esses europeus foram encontrados por Martim Afonso de Sousa, chefe da grande expedição colonizadora que $\circ$ Reino de Portugal mandou em 1531 ao Brasil.

Ahí, na terra cannanéense, este nobre lusitano, Martim Afonso, encontrou alguns homens civilizados, talvez criminosos deportados em anno de 1501 ou 1502, entre os quais figuravam o não menos celebre bacharel Chaves, denominado na nossa historia pátria o becherel de Cananéa, julgando alguns historiadores nacionaes ser elle o conhecido João Ramalho, o sogro do nosso primeiro cidadão paulista Tibiriçá. Esses desterrados foram, incontestavelmente, de enorme utilidade para Martim Affonso de Sousa, pois, sendo conhecedores da língua dos índios, que habitavam as proximidades do futuro e futuroso porto de Cananéia, serviram de interpretes a esses arrojados viajantes (KRUG, 1939, p.9).

Não se sabe ao certo o nome da personagem citada. Sendo chamado por uns e por outros de João Ramalho, Antonio Rodrigues, Duarte Peres, Gonçalo da Costa, Francisco de Chaves, Mestre Cosme ou Cosme Fernandes, seu verdadeiro nome ainda permanece uma incógnita. O Bacharel era um homem letrado, falava bem, pois teria sido formado em Coimbra e gozara de grande prestígio na Corte de Dom Manuel, antes de cair em desgraça e ser degredado para o Brasil. Todos os autores relatam seu desterro e de como se tornou tão importante para a história deste país, prestando relevantes serviços aos navegantes europeus, fornecendo-lhes os mantimentos necessários e facultando-Ihes os meios de manter relações amigáveis com os habitantes nativos.

O Bacharel de Cananéia, por questões políticas e econômicas, foi desterrado de Portugal e deixado em Cananéia. 
Era cristão novo (judeu converso). Acredita-se que chegou ao Brasil pela expedição comandada por Gonçalo Coelho (Santos, 2010) ${ }^{10}$.

Gonçalo Coelho saíra de Portugal em 1501, chegando ao Brasil em 24 de janeiro de 1502, para reivindicar e demarcar as terras para a coroa portuguesa. No Brasil, o Bacharel casou-se com a filha de um cacique carijó (e outras índias) e teve muitos filhos, sendo chamado rei branco. Eduardo Bueno considera-o como o "primeiro senhor de escravos do Brasil". Ainda teve participação no primeiro conflito armado brasileiro conhecido como Guerra de Iguape. Provavelmente fora morto pelos índios carijós, em 1537.

Hans Staden chegou à região de Cananéia, após uma grande tempestade no ano de 1547, e encontrara a região habitada por indígenas e europeus que ali viviam e mantinham relações de aliança e troca:

Deviam ser duas horas da tarde quando baixamos âncora. No início da noite aproximou-se do navio um grande barco repleto de selvagens. Queriam falar conosco, mas nenhum de nós podia entender a língua que falavam. À noite, de novo veio um barco cheio de gente, e entre eles estavam dois portugueses que nos perguntaram de onde éramos [...] Perguntamos então a que distancia ficava a ilha de Santa Catarina, para onde queríamos ir. Eles responderam que poderia ser a trinta milhas ao sul. Lá vivia uma tribo de selvagens chamados carijós, com os quais deveríamos ter muito cuidado. Os nativos da região de Superagüi, os Tupiniquins, no entanto, eram amigos, e deles nada tínhamos a temer (STADEN, 2009, p. 45).

De acordo com Young (1902, vol. VI) ${ }^{11}$, foi da frota de Martim Afonso de Sousa, ancorada na llha do Abrigo, em frente à

10 SANTOS, M. Walburga. Saberes da Terra: o lúdico em Bombas, uma comunidade quilombola (estudo de caso etnográfico), 2010.

${ }^{11}$ Ernesto Guilherme Young - vida e obra. Disponível em: 
Cananéia, que saiu a primeira expedição organizada com o objetivo de procurar ouro no Brasil, no dia $1^{\circ}$ de setembro de 1531. Consta que essa expedição, comandada por Pedro Lobo e mais oitenta homens, nunca voltou, fora destruída pelos índios carijós nas cabeceiras do rio Iguaçu, campos de Curitiba (Azevedo Marques apud PETRONE, 1966).

Em artigo publicado na revista SESC ${ }^{12}$, Cecília Prado discorre sobre essa expedição como tendo uma missão tríplice: combater os traficantes franceses, incrementar o povoamento do Brasil e procurar tesouros andinos, justamente usando os conhecidos caminhos da mata (na época). Tal expedição ocorrera antes da fundação de São Vicente, a primeira vila portuguesa da América. Em seu artigo, a autora observa que havia um caminho conhecido dos exploradores chamado Peabiru, uma rota transcontinental précabralina, muito usada pelos indígenas brasileiros e os primitivos povos andinos. Designada como caminho ou sistema do Peabiru, ela ligava o oceano Atlântico ao Pacífico de uma maneira surpreendente: fazia a ligação com os Andes; cortava o solo do Paraguai, entrava no Brasil na altura do rio Piqueri e, depois, atravessava os rios Ivaí e Tibagi; bifurcava-se na altura do Vale do Ribeira, na região de Apiaí. O tronco principal seguia até São Vicente, enquanto outras ramificações continuavam para Cananéia e Iguape. Tal dado é de extrema importância, pois se pressupõe que a região do Petar, objeto deste trabalho, tenha sido rota de circulação não só dos indígenas brasileiros, mas também dos andinos que podem ter deixado algum traço em topônimos da região. Cecília Prado afirma que, embora alguns estudiosos digam

$<$ http://my.opera.com/perfeito/albums/showpic. $d m \mid$ ?album=904595\&picture=99124042 , acessado em abril 2012.

${ }_{12}$ Peabiru a Trilha Misteriosa. Disponível em: http://www.sescsp.org.br/online/artigo/5670 PEABIRU+A+TRILHA+MISTERIOSA\# tagcloud=lista Acessado em abril de 2013. 
que o termo Peabiru tenha origem tupi-guarani (pe: caminho; abiru: gramado amassado ou, ainda, caminho da montanha do sol), para outros, como Sérgio Buarque de Holanda e Luiz Galdino, essa é uma designação que somente passou a ser utilizada no século XVII, quando os paulistas descobriram que biru era o nome dado ao Peru por seus habitantes. De acordo com estes historiadores, o primeiro a utilizar um simulacro dessa palavra não teria sido, como em geral se afirma, o jesuíta Pedro Lozano, mas, sim, Díaz de Guzmán, autor de Historia da Argentina, que se referiu ao peabuyu. Nesse sentido, faz-se necessário observar que Peabiru pode ter sido uma rota intercontinental usada pelos incas, sendo tal afirmação justificada por meio do topônimo.

Reinhard Maack (apud PETRONE, 1995, p.35) argumenta que o Peabiru teria sido "o caminho transcontinental mais importante da época anterior ao descobrimento da América". Denominado Peabiru pelos indígenas, dirigia-se do atual litoral paulista, em São Vicente, para o sul, rumo ao rio Paranapanema e, de lá, para uma das principais nascentes do rio Ribeira acima até os campos de Castro (rio Tibagi, no Paraná). De acordo com Washington Luis, teria sido um caminho "muito batido, com uma largura de 8 palmos, estendendo-se por mais de 200 léguas desde a capitania de S. Vicente, da costa do Brasil, até as margens do rio Paraná, passando pelos rios Tibagy, Ivaí e Pequeri” (PETRONE, 1995, p.35).

Há a versão descrita pelos jesuítas que se apropriaram de um mito indígena. Contam que esse seria o Caminho de São Tomé e que tal sistema teria sido construído, segundo a tradição indígena, pré-cabralina, por uma figura de super-homem/semideus chamado Sumé, nome que seria uma corruptela de São Tomé, um dos apóstolos de Cristo. Sumé é descrito como um homem branco de 
porte gigantesco e barbudo que teria percorrido o território da América do Sul ensinando aos índios técnicas agrícolas, como o cultivo da mandioca e da banana são tomé e os assim chamados hábitos civilizados. Repudiando a poligamia e a antropofagia, consta que o santo teria provocado a ira dos nativos, sendo obrigado a fugir, para sempre, de suas aldeias. Outra e nova versão conta que Sumé, ao ser perseguido pelos tupinambás, foi para o Paraguai e, então, para o Peru. Para esta travessia, teria aberto uma estrada que ficou conhecida como Peabiru ou Caminho das Montanhas do Sol. Igor Chmyz, arqueólogo e pesquisador paranaense, refez, em 1970, parte do caminho encontrando marcos e inscrições em rochas. Essa descoberta parece confirmar a relação entre os indígenas do Brasil e os do Peru.

Foi pelo Peabiru que a civilização europeia entrou a oeste e subiu até os Andes. Um fato que expressa a velocidade da penetração é a existência do galo, que entrou em 1502 em Cananéia e que, já em 1513, era encontrado na Corte Incaica que ficara visivelmente impressionada por tal animal de tal modo que o futuro reinante tomara seu nome: Atahualpa, que, em quéchua significa ave da fortuna. "Esta rapidez na dissimilação dum elemento cultural prova quanto eram rápidas $e$ ativas as comunicações através do continente (...)", admite Cortesão.

O mais conhecido é o Caminho do Peabiru ou Caminho de São Tomé que ia dos atuais litorais (paulista e paranaense) até Cuzco, passando pelas regiões hoje conhecidas como Paraná, Mato Grosso do Sul e Paraguai. Entre vários viajantes, Álvar Núñez Cabeza de Vaca foi um dos que utilizaram o caminho em suas viagens. Como já foi dito, há várias informações sobre a origem desse caminho, acrescentando-se que alguns pesquisadores acreditam que era uma rota indígena construída em épocas pré- 
colombianas, outros defendem sua origem entre os incas. Essa é uma discussão que está longe de ser encerrada, muito ainda está sendo considerado.

Petrone argumenta que "a longa estrada" (como ele chama o Peabiru) teria sido o instrumento de construção do sentido continental do povoamento indígena naquela parte do país, estabelecido pelas relações entre os campos de Piratininga e a mesopotâmia paraguaia. Tal situação ligava as tribos da nação guarani, da bacia do Paraguai, com a tribo dos Patos, em Santa Catarina, com os Carijós de Iguape e Cananéia assim como com as tribos de Piratininga e do litoral próximo.

Parece que esse longo caminho ligando todo o sul do continente americano ou, mesmo, podendo chegar até o pacífico passando pelos Andes existiu de fato e que o percurso descrito esteja correto. Assim sendo, a região de Iporanga/Apiaí e do Petar fariam parte dessa rota. Como afirmado anteriormente, essa população transcontinental pode ter deixado traços de sua presença em denominativos de lugar, de plantas, animais.

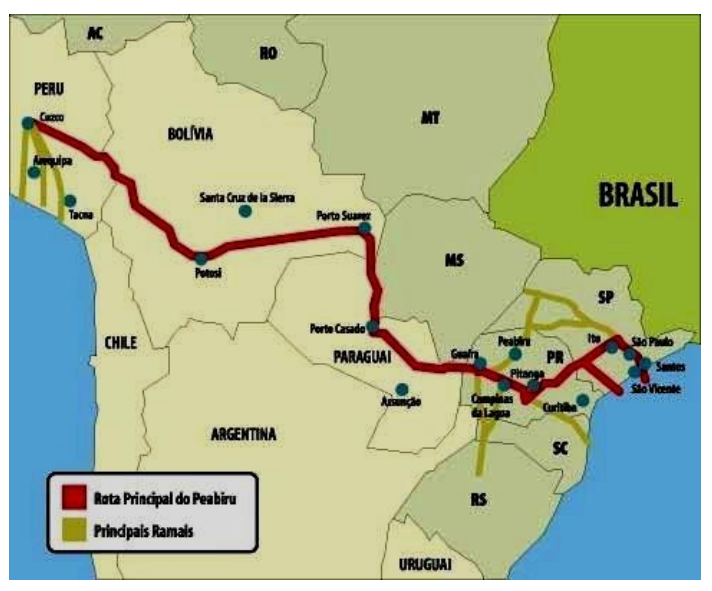

Rotas do Peabiru/ Arte PB 
Houve certo isolamento que possivelmente marcou a região até as primeiras décadas do século XVII.

Embora algumas bandeiras de apresamento tenham atravessado o interior do Vale, a região deveria ser sertão bruto, praticamente desconhecido do europeu e apenas habitado por poucos indígenas, a exemplo do aldeamento que deveria existir onde surgiu o núcleo de Xiririca, atual Eldorado (Bruno \& Ernani apud Petrone, 1966:73)

A região do Vale do Ribeira, em especial a vizinhança de Iguape, foi uma das primeiras áreas de onde se extraiu ouro no Brasil como consta de excerto de carta citada por Young:

Por uma carta escripta no dia 26 de Outubro de 1635 vê-se que naquelle tempo o povo de lguape usava de ouro em pó em suas transacções commerciaes. Pelo menos, assim se infere da leitura da dita carta.

Foi só na segunda metade do século XVI que as comunidades de Iguape e Cananéia se configuraram como núcleos urbanos expressivos, Iguape, de início na Barra de Icapara e Cananéia, na Ilha Comprida, com o nome de Maratayama. Essas duas povoações se beneficiaram do interesse que a região começou a despertar entre os moradores de outras áreas do Brasil devido à descoberta de jazidas de ouro nas imediações de lguape e em outras regiões da costa sul.

De acordo com Petrone (1966), a procura de jazimentos auríferos levou os exploradores Ribeira acima, infiltrando-se em muito de seus afluentes e subafluentes. Chegaram à região de Xiririca, onde o metal parece ter sido encontrado em quantidade apreciável. Dali, eles disseminaram-se, criando, pouco a pouco, condições para que se definisse o povoado de Xiririca, provavelmente o primeiro núcleo de povoamento com base na presença de primitivo aldeamento indígena. 
O período de exploração do ouro é tido como o primeiro ciclo de desenvolvimento da região do Vale do Ribeira. A descoberta de ouro nas Serra de Paranapiacaba e do Cadeado (Cananéia) determinou um processo de ocupação do interior, em especial nas regiões de Iporanga e Apiaí, marcando a paisagem econômica da região, da qual sobretudo o núcleo de Iguape se beneficiou. $\mathrm{O}$ ciclo do ouro começou por volta de 1550, quando foi encontrado ouro de aluvião no interior do Vale do Ribeira: no Alto Ribeira, na região de Apiaí e Iporanga, no Médio Ribeira, em Eldorado (antiga Xiririca), também foi encontrado ouro em Cananéia (antiga(Maratayama) e no litoral do Paraná.

No Alto Ribeira, a exploração de ouro foi mais intensa ocupando grande número de escravos, primeiro os índios e posteriormente os negros. Com o aumento das incursões rumo ao interior, a partir do século XVII, formaram-se mais de 12 localidades, tendo como principal atividade a extração de ouro, nas quais a agricultura de subsistência também foi desenvolvida $\left(\right.$ KRUG, 1939) ${ }^{13}$.

Como primeiro núcleo de exploração de ouro do Brasil, admite-se que houve muito mais ouro retirado da região do que os dos dados oficiais. Para Young, a quantidade de ouro que passava pela fiscalização colonial nunca representou o verdadeiro valor da extração, pois, se tem registro de que a atividade era realizada por aventureiros que atuavam frequentemente à margem do controle oficial.

Houve uma época em que o extravio era tão grande que o governo para evital-o, mandou edificar uma casa na margem do rio Ribeira, para logar onde os mineiros, descendo em canoas eram obrigados a passa, sendo ahí estabelecido um guarda fiscal para revistar os

13 KRUG, 1939, 563 apud Cadernos do ITESP n.3. Negros do Ribeira: Reconhecimento Étnico e Conquista do Território, 2000, p.62. 
mineiros e registrar a quantidade de ouro que traziam para a Villa. O logar onde foi estabelecido essa guarda é conhecido até hoje pelo nome de "Registro" (YOUNG, 1902, p. 410).

A exploração do ouro de lavagem se fez apenas ao longo do Ribeira e seus afluentes. Foi essa atividade que justificou a penetração do povoamento para o interior, caracterizada pela instabilidade de fixação decorrente da mobilidade do explorador. A atividade de bateação ${ }^{14}$ foi acompanhada do plantio de roças apenas para a subsistência e sempre marginalmente aos rios. Como consequência, de acordo com Petrone (1966), apenas ranhuras da presença dos povoadores, como anteriormente o fora a dos indígenas, deviam ter sido feitas nas paisagens naturais do interior. A natureza, quase intacta é ainda hoje o valor mais cultuado da região, tendo a maior quantidade de Unidades de Conservação do Estado de São Paulo, sendo uma delas o Petar, objeto desta pesquisa.

O ano de 1576 é considerado o ano de fundação de Iporanga com a presença de bandeirantes a procura de ouro. Os primeiros vestígios de ocupação foram encontrados a $8 \mathrm{~km}$ da foz do ribeirão Iporanga, afluente do rio Ribeira do Iguape. Ali, os faiscadores de ouro, dentre eles Garcia Rodrigues Paes e José de Moura Rolim, fundaram um dos primeiros núcleos coloniais da Serra de Paranapiacaba, o Garimpo de Santo Antonio, deram início a construção de cabanas de madeira e barro e construíram muralhas para se precaverem contra possíveis ataques dos bugres.

Em 1625, o Arraial de Santo Antonio tinha uma capela coberta de sapé e seu administrador era o Padre José Maria Tinoco. Nessa

\footnotetext{
${ }^{14}$ Bateação: atividade na qual o garimpeiro lava o cascalho extraído dos rios ou riachos com bateia, espécie de bacia em formato de chapéu chinês para separar as pepitas de ouro das pedras do cascalho.
} 
mesma época, surgem também os primeiros cultivos de subsistência: a cana de açúcar e alguns cereais ${ }^{15}$.

Entre os autos velhos que existem nos cartórios, encontrou-se parte de um no qual Domingo Rodrigues Cunha, no ano de 1655, dizia:

(...) teve uma sociedade com seu... Antonio Roiz Cunha em huma lavra que comprarão com dez escravos do defunto Antonio Soares de Azevedo em que trabalhou durante um anno." Diz mais " estava nas lavras de l'poranga anno e meyo", como também, "nas minas de Apiahy, Sorocaba e nas de l'vupurunduba por duas vezes trabalhando (YOUNG, 1902).

A partir de 1676, com a vinda de novos faiscadores e a prosperidade econômica, inicia-se a formação do porto Ribeirão, na foz do rio Iporanga, às margens do Ribeira. O objetivo da mudança era facilitar o intercâmbio de mercadorias, posto que o acesso ao Ribeira se tornara muito difícil.

O esgotamento do ouro levou à mudança da localização de Iporanga, em 1730, para as margens do Ribeira, colocando o arraial como entreposto comercial estratégico e de escoamento da produção agrícola excedente entre o lguape e as localidades rio acima, estas alcançadas por antigos e precários caminhos terrestres. Essas rotas de tropeiros podem ainda hoje ser visitadas na região do Petar pelo turismo, por estarem bem conservadas e guardarem as mesmas características dos tempos em que foram a única opção de ligação entre o litoral e o planalto.

\footnotetext{
${ }^{15}$ Há controvérsias entre o que é apresentado no site do IBGE e os dados de historiadores. Diante disso, resolveu-se não excluir os dados divulgados pelo Instituto, visto que não é o objetivo deste trabalho o estudo da historiografia e, sim, como a história participa na construção do ethos da população local, deixando marcas nos nome de lugar. Disponível em: <http://www.ibge.gov.br/cidadesat/topwindow.htm?1> Acessado em abril 2013.
} 
As atividades da Casa de Fundição de Iguape finalizaram-se em 1763, encerrando o período mais expressivo da mineração de lavagem que durara quase dois séculos. Apesar da diminuição da atividade mineradora na região de Xiririca (Eldorado), ela perduraria como atividade permanente até meados do século XIX em Iporanga, Apiaí até Paranapanema, quando se esgotam os últimos depósitos aluvionares de ouro conhecidos (STUCCHI, 2005, 110).

A entrada da mão de obra escrava e negra na região data de meados do século XVII e está ligada, principalmente, à atividade de mineração, diferente do que ocorria em outras regiões de São Paulo, onde estava associada à lavoura de café. Contingentes negros oriundos de Guiné, Angola e Moçambique foram levados a localidades Ribeira acima (Cadernos do Itesp, 2000).

O ouro foi extraído no rio Ribeira desde meados de 1600 até épocas próximas ao descobrimento das jazidas nas Minas Gerais, ou melhor, nos sertões dos Cataguazes, para onde se mudaram os mineradores em posse de seus plantéis de escravos.

A região de Iguape/ Cananéia e a de Xiririca (Eldorado) foram as que concentravam maior núcleo populacional no final do século XVII.

Antiurbanismo colonial é o termo usado por Pasquale Petrone (1966) para definir o caráter disperso da maior parte do povoamento da região, "o habitat era de uma dispersão primária absoluta" Os moradores, em sua maioria sem direitos de datas de sesmaria, instalando-se por simples posse, cultivavam o solo, utilizando o sistema de culturas itinerantes. Por muito tempo, os limites para suas atividades foram os morros, os brejos, os rios, as serras. São esses acidentes físicos, devidamente denominados pela população local que demarcarão o ethos toponímico do entorno do Petar. 
Certo isolamento ou dispersão na ocupação do solo ainda é marcante na região de Iporanga. Os bairros permanecem distantes do centro urbano, principalmente os bairros constituídos por comunidades quilombolas ${ }^{16}$ Poder-se-ia, talvez, considerar essa característica como uma tendência ou propensão dos moradores a se isolarem como abordou Aroldo Azevedo (1956) em relação aos primeiros habitantes.

Com a diminuição da exploração mineradora, a atividade agrícola de subsistência adquiriu maior estabilidade, atraindo famílias com o objetivo de explorar as terras, deslocando-se rio abaixo ou rio acima para plantar arroz, milho, mandioca, cana, café, fumo. A demanda por uma população urbana na região resulta na produção de bens de consumo como rapadura, farinha, aguardente, dando origem a uma nova paisagem urbana com comércio, novas casas assim como novos costumes.

Com a chegada da família real ao Brasil, em 1808, há um considerável aumento por alimentos e outros produtos agrícolas. A rizicultura tomou grandes proporções na região e reascendeu a importância das terras do Vale do Ribeira, gerando um novo ciclo de desenvolvimento na região. O cultivo do arroz deu-se ao longo do século XIX, quando a produção para o abastecimento de outras províncias da Colônia, principalmente o Rio de Janeiro, atingiu seus valores máximos, colocando Iguape na liderança da economia regional.

A comunicação do Alto Ribeira era insuficiente e muito difícil, pois o rio era a principal rota de ligação entre o litoral e o planalto. Em meados do século XIX, deu-se uma modificação importante: 0

\footnotetext{
${ }^{16}$ Entende-se por comunidades quilombolas as "formas diversas de formação e reprodução social de comunidades quilombolas, sendo desnecessário e inconveniente tomar um modelo fixo de quilombo como parâmetro" (SILVEIRA, 2003, p.13).
} 
início da navegação a vapor do Ribeira entre Iguape e Xiririca, feita pela Companhia Fluvial Paulista. Este fato intensificou o comércio e facilitou o escoamento da produção agrícola de Xiririca, Iporanga e toda a região do Alto e Médio Ribeira.

Em 1802, Iporanga recebe o Padre Bernardo de Moura Prado que, em 1814, junto com o Capitão José Moura Rolim e outros moradores da região, inicia um movimento para a construção de uma nova capela, a beira do Ribeira, onde estava instalada a maior parte da população. O padre conseguiu com a devota D. Escolástica Maria Carneiro a doação de um terreno para a construção da capela. Foi feito um mutirão para roçar e plantar arroz e arrecadou-se o total de $100 \$ 000$ (cem mil reis) para pagar o mestre de taipas, Francisco Alves. Em 1815, foi autorizada pelo bispo D. Matheus de Abreu Pereira e iniciada a obra, cujo término ocorreu em 1821. Essa igreja é, ainda hoje, um marco em Iporanga, junto ao casario de taipa e pau a pique.

Iporanga tornava-se um importante porto fluvial, havendo a construção de duas escadarias: porto do Ribeirão (porto de Baixo) e do Ribeira (porto de Cima).

A comunicação pelo rio e planalto intensificou o intercâmbio comercial entre as cidades de Itapeva (antiga Faxina), Itararé, Ibiúna, Itapetininga e Sorocaba. A figura do tropeiro se tornou tradicional e folclórica, segundo livros de nota da Vila de Sant'Ana de Iporanga, "em 1822, constam cadastrados 68 tropeiros e 42 proprietários de tropas".

A produção era escoada pelas precárias vias terrestres. Em 1830, iniciou-se a abertura de um caminho que deveria unir a Baixada à Itapetininga, mas foi interrompido pelas dificuldades para a transposição da Serra Queimada. Outros caminhos surgiram que conduziam Xiririca ao Capão Bonito e Iporanga à Itapeva, mas em 
1872 todos estavam obstruídos. Em consequência disso, a viagem continuava sendo feita pelo rio, levando cinco dias de viagem fluvial e quatro por terra para unir Iguape, no litoral, à Itapetininga, no planalto (PETRONE, 1966).

Em 09 de dezembro de 1830, atendendo ao pedido dos moradores, o povoado é elevado à categoria de Freguesia de Sant'Ana.

A agricultura e o comércio continuavam em franca expansão registrada nos livros: 16 indústrias de fumo, 52 engenhos de cana, 14 fábricas de rapadura, 12 fábricas de aguardente e diversos monjolos de cereais e, no mesmo ano (novembro), havia 1.200 moradores que se dedicavam à criação de porcos e ao plantio de arroz e cana.

Em 09 de janeiro de 1832, Iporanga é elevada à condição de Distrito de Paz, pertencendo, ainda, à Freguesia de Apiaí, unindose a Xiririca apenas em 1842.

Recém-criado, o distrito contava com trinta casas comerciais, quarenta fábricas de rapaduras, vinte oito fábricas de aguardente, vinte e duas fábricas de farinha, dois latoeiros, dois alfaiates, três ferreiros e um fogueteiro.

Em comemoração à coroação de D. Pedro II, a Companhia Lírica Francesa se apresenta no Rio e, dali, vai à Iporanga e inaugura o Teatro Recreativo Santana, em 1841. Nessa época, conta-se que os fazendeiros mais ricos mandavam seus filhos à Europa para estudarem, em especial Lisboa e Paris, esse dado confirma os ciclos de riqueza pelos quais a região passou.

Iporanga recebe iluminação pública com lampiões a óleo de baleia e braços de ferro importados da Bélgica. É o quarto município da Província a receber esse tipo de iluminação. 
Em 03 de abril de 1873, Iporanga desmembra-se de Xiririca, resultado de movimento popular liderado pelo coronel João Esteves Neves, com o nome de Villa de Sant'Ana de Iporanga, subordinada à Comarca de Faxina. Em 12 de janeiro de 1874, Iporanga torna-se município.

Desde 1865, realizava-se a Festa de Nossa Senhora do Livramento e São Benedito nos dias 31 de dezembro a 2 de janeiro. A festa consiste em uma procissão fluvial de embarcações em uma réplica de caravela portuguesa improvisada com canoas, trazendo os santos em seu interior, desce o rio Ribeira e ancora no ribeirão Iporanga com a multidão aguardando em procissão e se dirigindo à igreja. Ainda hoje essa é a festa mais importante da região e parece que seu prestígio aumenta a cada ano.

O ano de 1884 marca o final das obras da torre da igreja, arquitetada e construída pelo alemão Guilherme Loose. Antes do término, o sino com o brasão imperial foi mandado confeccionar na Bélgica, por meio de doação de um comerciante próspero, Sr. Joaquim da Motta e a contribuição do Imperador D. Pedro II no valor de dois mil contos de réis. Na inauguração, a torre já recebia os fiéis com o maravilhoso repique do sino. Dizem que em sua fundição, $2 \mathrm{~kg}$ de ouro extraídos do ribeirão Iporanga foi misturado ao puro bronze. Loose e Motta são ainda hoje reconhecidos como referenciais de lugar, do lugar onde viviam essas famílias.

A construção da ferrovia serra acima, ligando Apiaí a Itapeva, por onde eram transportados os produtos até Paranapanema, abala a conquistada relevância comercial de Iporanga. $O$ transporte fluvial foi-se tornando inviável e caro, em seu porto só as canoas, movidas a vara, chegavam. A situação de isolamento econômico reduz a produção agrícola local a características de agricultura de subsistência. 
A mão de obra escrava continuou a ser utilizada residualmente pelos fazendeiros economicamente mais poderosos, embora o número de escravos tenha diminuído em relação à época da exploração garimpeira. Enquanto que nas fazendas maiores, onde se localizavam as fábricas de pilar arroz, as dificuldades para a manutenção dos plantéis de escravos eram crescentes, os pequenos produtores, também dedicados ao cultivo do arroz, mantiveram em pequena escala a produção de outros gêneros destinados ao consumo doméstico, além de participar do circuito comercial regional.

No apogeu da monocultura do arroz com trabalho escravo, a região necessitou de uma crescente ampliação de mão de obra. Foi essa população quem, mais tarde, participou da formação dos quilombos, a partir da decadência do cultivo, em fins do século XIX. As ruínas das fazendas distribuídas na extensa zona rural dessa vasta região, o casario urbano dos núcleos de lguape, Iporanga e Cananéia, o canal do valo Grande, a população quilombola e seu modo de vida são alguns dos testemunhos presentes na paisagem desse momento de riqueza e auge, mas também do papel da região na economia do Brasil Império (NASCIMENTO e SCIOFONI, 2010).

A historiografia do vale do Ribeira de Iguape confunde-se com a história da formação das comunidades negras que participaram dos grandes ciclos econômicos de maneira marginal, porém articulada com os ocupantes brancos na região:

A presença autônoma ou relativamente autônoma das comunidades negras na região durante período escravagista brasileiro permitiu configurações de territorialidades tradicionalmente constituídas, que se redefiniram ao longo do tempo, consolidando-se como os inúmeros bairros rurais habitados 
predominantemente por negros do vale do rio Ribeira do Iguape $^{17}$.

Os bairros rurais (quilombolas) da região de Iporanga e Petar são Ivapurunduva, São Pedro, Pedro Cubas, Maria Rosa, Pilões, Sapatu, André Lopes, Nhunguara, Bombas, Poço Grande, Praia Grande. Todos eles localizados no entorno do Petar ou, até, dentro do parque como é o caso da comunidade de Bombas.

Com um sistema de circulação extremamente deficitário, a região do Vale do Ribeira vai isolar-se cada vez mais do restante do estado, fato que contribui para o desenvolvimento de uma agricultura de subsistência, denominada de caipirização do Vale. Essa situação permanece de 1910 até 1940, quando ocorre uma retomada da mercantilização da agricultura regional com a introdução do chá e da banana pelos imigrantes japoneses que vinham se instalando na região desde 1912 (Müller, 1980 apud TODESCO, 2007, 23).

Em Iporanga, essa retomada se dá com a indústria de cal e as pesquisas minerais de profundidade realizadas por Henrique Bauer, Ricardo Krone e Edmundo Krug (a espeleologia). Entre 1901 e 1920, as minas de chumbo do Alto Ribeira produziam o minério que era transportado pelos mesmos caminhos usados pelos tropeiros até chegar ao ribeira do Iguape, em Iporanga. Dali, seguia-se para o litoral, cujo destino final era o porto de Santos de onde era exportado.

Rebaixada a Distrito e anexada ao município de Apiaí em 1934, volta à condição de município em 1936, cujo prefeito, eleito em 25 de abril de 1937, fora Florencio Alves Pedroso. Essa gestão é marcada por duas tragédias: a enchente de 1937 que causou

\footnotetext{
${ }^{17}$ Negros do Ribeira: Reconhecimento Étnico e Conquista do Território. 2 edição. 2000, p.65. Cadernos do ITESP; 3.
} 
grande destruição e, em seguida, a epidemia da Malária em 1937 e 1938. Mais um período de retrocesso de Iporanga.

Na década de 1960, em função do regime militar e da luta armada, propôs-se um plano desenvolvimentista para a região, com o objetivo de conter uma suposta guerrilha coordenada por Carlos Lamarca que havia se refugiado na região; foi construída a estrada Eldorado- Iporanga - Barra do Turvo e a ponte sobre o rio Ribeira.

\subsection{Comunidades quilombolas do entorno do Petar}

Pelo caminho da violência, o negro foi trazido para o Brasil sob a condição mais degradante a que um ser humano pode ser submetido: a escravidão. Mas resistiu. Impregnou o Brasil de sua cultura e de seus valores. Lutou pela liberdade. Fincou sua bandeira em territórios livres. Continuou lutando contra a discriminação e pela sua afirmação cultural, social e econômica

Cadernos do ITESP 3, 2000,p. 65.

A chegada dos negros no Alto Ribeira coincide com a descoberta de ouro na região. Há dados historiográficos que comprovam que, a partir de meados do século XVII, mineradores já atuavam na região com seus plantéis de escravos. Eram escravos oriundos, principalmente, de Guiné, Angola e Moçambique (STUCCHI, 2005) ${ }^{18}$.

As comunidades remanescentes de quilombos da região do Alto Ribeira não podem ser caracterizadas pelo isolamento geográfico, de acordo com a definição clássica de quilombo que remonta o século XVIII e que afirma que quilombo seria "toda habitação de negros fugidios, que passem de cinco, em parte

18 STUCCHI, Deborah. Percursos em dupla Jornada: o papel da perícia antropológica e dos antropólogos nas políticas de reconhecimento de direitos. Tese de Doutorado, apresentada ao Departamento de Antropologia do Instituto de Filosofia e Ciências Humanas da Universidade Estadual de Campinas, 2005, p.109. 
despovoada, ainda que não tenham ranchos levantados nem se achem pilões nele" (Cadernos do Itesp 3, 2000, p. 50).

De acordo com Cardoso de Oliveira:

(...) a etnicidade refere-se aos aspectos das relações entre grupos que consideram a si próprios e são também por outros considerados como distintos. Do ponto de vista da interação, o processo de identificação étnica se constrói de modo contrastivo, isto é, pela afirmação do nós diante dos outros. (Cardoso de Oliveira, 1976-5 apud O'DWYER. "Terra de Quilombo", IN: TOMO, Revista do Núcleo de Pós-graduação e Pesquisa em Ciências Sociais Universidade Federal do Sergipe).

A interação com a sociedade local, marcada pelas relações sociais e sua forma de ocupação do solo, assinala um padrão típico que pode ser observado ainda hoje na vida dessas comunidades. Serem escravos fugidios deixa de ser o componente principal que os caracteriza como quilombolas, a transição dessa condição para camponês livre é o que realmente condiciona a situação de comunidade remanescente de quilombo.

Os laços com a África deixam de ser fundamentais para qualificar uma comunidade como remanescente de quilombo. O atributo de resistência e autonomia à ordem estabelecida e a luta por um lugar social tendo a liberdade como horizonte são historicamente os fatos que marcam essas comunidades.

Assim apenas os fatores socialmente relevantes podem ser considerados diagnósticos para assinalar os membros de um grupo sendo que a característica crítica é a autoatribuição de uma identidade básica e mais geral que, costuma ser determinada por sua origem comum e formação no sistema escravocrata (BARTH, 1969 apud O'DWYER. "Terra de Quilombo", IN: TOMO, Revista do Núcleo de Pós-graduação e Pesquisa em Ciências Sociais Universidade Federal do Sergipe). 
A preocupação em cumprir padrões pré-estabelecidos pelos agentes externos pode vir a descaracterizar e mesmo comprometer o funcionamento dessas comunidades. Ao reivindicarem seu direito estabelecido pela constituição ${ }^{19}$, essas comunidades se sentem muitas vezes aprisionadas a um modelo pautado em um passado colonial. Também a interferência do poder econômico externo em comunidades com um sistema de trocas baseado no uso comum dos recursos pode comprometer o processo de independência econômica em curso.

O direito a um modelo próprio de sociedade que respeite seus lugares culturais e sociais tem sido a reivindicação de toda a comunidade que atua em defesa da legitimação dos territórios quilombolas do Vale do Ribeira.

Nas últimas décadas, vários acontecimentos que marcaram uma transformação na ocupação do Vale do Ribeira, comprometeu o modo de vida dessas comunidades. A ameaça de construção de usinas hidrelétricas, pela Companhia Energética do Estado de São Paulo, que começou nos anos 50, e, mais recentemente, a de Tijuco Alto, pretendida pela Companhia Brasileira de Alumínio, do grupo Votorantim, é exemplo de um desses fatores desestruturantes na vida dessas sociedades. Essas construções preveem a inundação de territórios ocupados por grupos ribeirinhos e quilombolas que são parte do desenho étnico/social da região do Vale do Ribeira.

Outro fator que deve ser levado em consideração é a criação de Unidades de Conservação na região. O Vale do Ribeira é conhecido como a região do Estado de São Paulo com maior

\footnotetext{
${ }^{19}$ Art. 68 do Ato das Disposições Constitucionais Transitórias da Constituição Federal de 1988: Aos remanescentes das Comunidades de quilombo que estejam ocupando suas terras é reconhecida a propriedade definitiva, devendo o Estado emitir-lhes os títulos respectivos.
} 
concentração de remanescentes de Mata Atlântica. Aproximadamente $60 \%$ de sua área é coberta por vegetação natural protegida por legislação que estabelece restrições de uso, sendo $20 \%$ de todo o território do Vale do Ribeira constituído por parques, estações ecológicas e outras áreas de proteção (Secretaria do Meio Ambiente apud Cadernos do Itesp 3, 2000, p.59). Muitas Áreas de Proteção Ambiental tiveram seus limites decretados em sobreposição a territórios de comunidades quilombolas, modificando radicalmente seu modo de vida. O plantio das roças de coivara ${ }^{20}$, ou roça de capuava, prática tradicional das comunidades quilombolas, torna-se ilegal. Desse modo, a legislação ambiental acaba por inviabilizar a reprodução de um padrão de ocupação típico dessas populações. Além disso, outra série de restrições impostas pela legislação ambiental igualmente dificultam a continuidade do uso social e cultural do território. O Petar está inserido nessa área e, de certa forma, também interfere na dinâmica dessas comunidades.

Em tal contexto, os nomes de lugares, os topônimos, são também parte da identidade cultural e social das Comunidades Remanescentes de Terras de Quilombo e configuram o território, ou melhor, a sistematização desse espaço em significações que devem ser preservadas. Os bairros rurais predominantemente habitados por negros do vale do rio Ribeira de Iguape podem não trazer em sua conformação toponímica traços relevantes de uma

\footnotetext{
${ }^{20}$ Caboclos e quilombolas da região do Alto Ribeira trabalham a terra como seus ancestrais, roçam, queimam e plantam o arroz, o milho, a mandioca. Trabalham a terra por dois ou três anos de plantio, depois a deixam descansar por cinco anos e realizam o mesmo trabalho em outro pedaço de terra. Isso faz que as matas se recuperem rapidamente. Entretanto, qualquer redução do período de pousio ou aumento no tempo de plantio, situações provável quando há aumento populacional e, portanto, na demanda por terras, pode colocar essa situação em risco.

Disponível em: http://prosanaserra.pilarcultural.org/2011/04/02/roca-de-coivara, acessado em 01-07-2013.
} 
africanidade que, como visto anteriormente, não está presente na formação dessas comunidades. No entanto, de certa forma, os topônimos da região expõe relações sociais e culturais que explicitam elementos constitutivos da vida dessas populações e, portanto, podem ser considerados traços constitutivos de uma identidade étnica:

a identidade étnica tem sido diferenciada de outras formas de identidade coletiva pelo fato de ela ser orientada para o passado. Essa referencia a uma origem comum presumida, parece recuperar, de certo modo, a própria noção de quilombo definida pela historiografia. Vale assinalar, contudo, que o passado a que se referem os membros desses grupos não é o da ciência histórica, mas aquele em que se representa a memória coletiva - portanto uma história que pode ser igualmente lendária e mítica (O'DWYER, Eliane Cantarino. Quilombos: identidade étnica e territorialidade, 2002, p. 4).

A nomenclatura toponímica desses bairros rurais denota uma ocupação peculiar representada por sítios que são unidades menores, pertencentes às famílias, inseridas na unidade territorial maior que é o bairro. Essa nomenclatura é indicativa de um modelo de territorialidade característico das comunidades do Alto Ribeira que se deu, principalmente, por laços de parentesco. Turatti afirma que:

Ao pensarmos sobre a formação (das comunidades negras do Ribeira) é mister não procurar um mito de origem ou um herói fundador. Explique-se: está claro que as comunidades foram estabelecendo-se em territórios mais ou menos fixos - é preciso recordar o próprio modo como estas comunidades praticam a agricultura requer uma mobilidade muito grande - e firmaram relações de aliança entre elas, sobretudo por meio dos casamentos intergrupais (...). Isso posto, entendemos que cada comunidade possui de fato seus principais e tradicionais núcleos familiares mas que a 
existência de parentelas extensas espalhadas pelas diversas comunidades reforça a ideia de que,no Vale do Ribeira, os diversos grupos negros que lá se fixaram são descendentes de escravos, ainda que não precisemos de quais eram ou quais plantéis faziam parte (Turatti, 2000, apud SANTOS, 2010, p.128).

Em Ivaporunduva, encontra-se Cortesias, Martins, Passagem, Boa Vista, Morro Grande, Vargens, Santo Antonio, Rodrigo, Mundéo, Chumbo, França, Laranja Azeda, Pilões, Bocó. "Mais pessoas fugiram e juntaram na praia que eles chamaram praia do Gregório Marinho e foi juntando aquele montinho"21.

Esse fazer denominativo explicita os nós dos grupos, ou melhor, o membro agregador de uma teia familiar ligada por laços de parentesco, mesmo que esse laço seja por afinidade, quer seja compadre, comadre, afilhado etc., e não só por consanguinidade.

2.3.1 Ivaporunduva, situada no município de Eldorado, antiga Xiririca, é a mais antiga das comunidades remanescentes de quilombos do Vale do Ribeira:

Logar ermo e habitado por algumas famílias de pretos descendentes de escravos...Umas capellinha sem architectura alguma, apenas com uma larga porta no pavimento térreo e duas janellas no andar superior, que dão luz ao côro, está construída no logar mais alto da beira do Ribeira: íngremes morros, como o morro da Joanna e outros, cercam-n a pelo lado de traz, dando assim ao logarejo uma vista agradável e poética (KRUG, 1942, 272).

A ocupação do bairro deu-se principalmente por mineradores e seus escravos já a partir de 1720. A narrativa de sua história, associada à atividade mineradora, relata que dois irmãos

${ }^{21}$ Comissão Geográfica e Geológica do Estado de São Paulo, 1994, IV. 
mineradores, Domingos Rodrigues Cunha e Antonio Rodrigues Cunha, apareceram como os primeiros habitantes da localidade.

Em outubro de 1791, foi inaugurada a Capela de Nossa Senhora do Rosário dos Pretos de Ivaporunduva, primeira igreja construída no Alto Ribeira. Segundo seus moradores, a construção teria sido em data anterior, entre 1630 e 1690. Como a chegada dos irmãos mineradores àquela região pode ser confirmada em documento de 1655 , citado por Young ${ }^{22}$, é bem provável que a construção da capela tenha sido de fato construída em data anterior à inauguração.

$1^{\circ}$ uma sociedade [de Domingos Rodrigues Cunha] com seu Irmão Antonio Rodrigues Cunha em huma lavra que comprarão com dez escravos do defunto Antonio Soares de Azevedo em cuja trabalhava serviço braçal e ao mesmo tempo feitorisando os escravos todo por tempo de hum anno (YOUNG, 1895).

Que elle achando-se nas lavras de Upuranga anno e mejo em todo este tempo andava em cobrança do sitio seu Irmão fazendo os gastos e da custa e em três viagens que fizera as minas do Piahy, a huma cobramço de Capp. Mor Fran. Alves Marinho sem o dito seu Irmão Ihe desse desgostos (YOUNG,1895).

Pode-se verificar que, de acordo com os excertos acima, ao chegarem à região os irmãos já encontraram a lavra de ouro e escravos, demonstrando que na região do Alto Ribeira a chegada de escravos se deu já ao final do século XVI ou início do século XVII.

De acordo com relatos dos moradores e registros do Livro de Tombo, as terras de Ivaporunduva foram doadas por Joana Maria

${ }^{22}$ YOUNG, E. Esboço Histórico da Fundação da Cidade de Iguape. 1895, p.105106. 
aos escravos que a serviram, contemplando-os também com a liberdade antes de morrer:

falecida aos 2 de abril de 1802, com idade de 90 annos, sem deixar bens alguns, porque em vida soube distribuil-os, e remunerar com a liberdade os escravos que lhe servião (Cadernos Itesp 3, 2000, p. 67).

Contam que Joana Maria chegou à região trazendo consigo escravos negros para o serviço da mineração do ouro. Mandou construir uma casa para sua morada, da qual existe apenas vestígio do alicerce e uma capela para realizar as celebrações religiosas (Cleide Rodrigues Amorim).

Como consequência da atividade de extração de ouro de lavagem, a ocupação da região do Alto Ribeira caracterizou-se por intensa mobilidade geográfica. Pequenas roças de subsistência garantiam os suprimentos necessários à manutenção dos plantéis.

A diminuição da população branca na região se dá com a redução da produção de ouro em meados do século XVIII. Como consequência, os escravos foram alforriados ou simplesmente abandonados e entregues à própria sorte, ampliando assim as áreas ocupadas pela população negra na região e, em especial, em Ivaporunduva:

Ivaporundyba ou Vaporundyva. Ilha e Ribeirão. Bairro. Pede a antiguidade e os Sucessos deste bairro tão celebre que nos demoremos algu'a coisa na sua exposição, Mui propriamente significa este nome: Rio de muito Vaporú, fruta. O Bairro pois de Ivaporundyba, nos seus primeiros tempos Arrayal de minas, consta ter sido quando não dos primeiros mais antigos, ao menos habitado já antes da Creação desta Freguesia. Mas ver agora, dentro de ppoucos annos já não digo o espaço de algu'as legoas até as vargens por onde se andava expeditamente noite e dia, mas somente o Lugar da commú Freguezia cuberto de matos, despido de tantas cazas e ranxarias, sem a pastaria de gados, q'econtava, 
sem o recíproco commercio, que se fazia com a influencia do Oiro, dos extranhos e moradores. Sem aquelle numero de escravaturas, q' era o arrimo dos mineiros, cujos nomes em parte se esquerão, em parte apenas se recordão;ver digo, este agradável Arrayal já extincto, e existindo apenas Hua Capella, esforço e empenho dos Pretos escravos affeiçoados a Devoção de Nossa Senhora do Rozario, parece se pode justamente dizer q'esta, mais Louvavel Obra He como o ultimo Suspiro de tantos trabalhos e fadigas, que alli se havião empregado (Livro de Tombo da Paróquia de Xiririca, apud STUCCHI, 2006).

O crescimento da produção agrícola possibilitou a transformação dos negros em pequenos produtores fixados em terras apossadas mato adentro. À beira dos rios que deságuam no Ribeira, plantava-se arroz, feijão e milho, motivados pela facilidade de comercialização de sua produção em Iguape por meio das embarcações que navegavam o rio.

Refugiando-se nas práticas de uma economia de subsistência, ancorado no cultivo de pequenas roças, sobretudo arroz, milho e feijão - suplementando a atividade agrícola por meio das atividades de pesca, coleta e caça, apossaram-se de parcelas livres relativamente próximas ao centro do povoado e isolaram-se em núcleos familiares, que compunham um grupo mais extenso e igualitário, graças aos vínculos de solidariedade e de sociabilidade baseados nas obrigações mútuas próprias do parentesco, da vizinhança e do compadrio. Construíram enfim uma identidade própria, centrada na origem comum, na cor da pele e sobretudo na devoção à Santa Padroeira de Ivaporunduva, Nossa Senhora do Rosário dos homens Pretos. $\mathrm{E}$ assim permaneceram durante décadas $\mathrm{e}$ décadas, até meados de 1950 (AMORIM, 1998) ${ }^{23}$.

${ }^{23}$ Disponível em:

http://www.eaacone.org/quilombos-vale-do-

ribeira/eldorado/ivaporunduva/newscbm_841933/100/, acessado em 03-07-2013. 
2.3.2 A comunidade quilombola de Maria Rosa faz divisa com o Petar, sua formação está ligada à da comunidade de Pilões e, em razão de praticamente coviverem no mesmo território, acabam por compartilhar a mesma origem.

Antigo limite de Freguesia, o topônimo Pilões aparece em documentação do Livro de tombo da Paróquia de Xiririca na página 22 em Termos Dividendes, Extensão e Nomes de bairros, e Logares d'Esta Freguesia em seu parágrafo primeiro:

O Ribeirão dos Pillõens, inclusive da parte superior, e a pedra grande chamada Fortaleza, e na língua da terra lyquyá, inclusive da parte inferior, são os termos demarcantes d'esta Estolla, ou Freguezia de Nossa Senhora da Guia e Xiririca, a respeito das Freguezias suas vizinhas limítrofes, que são a Villa de Apiahí, e a Villa de lguape, devendo por conseguinte abranger todos os rios que desaguão dentro das mencionadas demarcaçõens...

O marco divisório da Freguesia de Xiririca e Apiaí foi deslocado para mais abaixo, de forma que os bairros de Maria Rosa e Pilões passaram a pertencer ao distrito de Iporanga.

A origem do denominativo Pilões é explicada no livro de tombo da paróquia de Xiririca:

Pilloens, Ribeirão. Bairro e Demarcação superior. O nome desse caudaloso rio, cheio de cachoeiras, provem ao que dizem, de achar-se n'aquelles tempos hú pilão de madeira/ou no mato, ou mesmo no rio (Cadernos do Itesp 3, 2000, p. 93 //ou STUCHI, 2005, p.147).

Há outras versões contadas pelos moradores locais sobre a origem desse topônimo, uma delas relata que "chama-se porto dos Pilões porque existia buracos nas pedras de rio igual a um pilão, pois hoje não existe mais" (relatado, em 1991, por Pedro Rodrigues, morador do bairro a pedido de sua mãe Antonia Vitalina 
de Oliveira, na época a moradora mais antiga, In Cadernos do Itesp, 2000, p. 93). Pedro Rodrigues conta que a ocupação do bairro é muito antiga e nem sempre possível de ser resgatada, pois as famílias se sucedem umas as outras e, muitas vezes, não guardam a memória dos antepassados. $O$ que pode ser constatado por testemunhos, inclusive o de sua mãe, é o de uma origem remota camponesa com relações fortes de parentesco e com traços de religiosidade muito intensa, comum à época.

A economia de subsistência foi característica da formação de todas as comunidades quilombolas do Vale do Ribeira, sendo a produção excedente comercializada para suprir necessidades de bens não produzidos dentro das comunidades como, por exemplo, tecidos. Havia entre elas uma autossuficiência em conhecimentos tradicionais para lidar com os problemas do dia a dia. Como lembra Carril, em todo o Vale do Ribeira ocorreu o mesmo processo de formação histórica:

(...) a saída dos brancos ocorreu também em função da busca de riquezas em outras regiões. Os negros permaneceram, relacionando-se de forma orgânica com a terra, através do que estabeleceram fortes laços de solidariedade e união, bem como conhecimento do espaço em que vivem (...) mantiveram, a exemplo dos demais grupamentos negros, somente as casas particulares e o terreno em volta do plantio (CARRIL, 1995, 103 apud STUCCHI, 2005, p 150).

$\mathrm{Na}$ comunidade de Maria Rosa, os relatos também não identificam um nome que esteja associado à formação do bairro, apenas afirmando que ali sempre fôra habitado por negros, somente negros.

Os ciclos econômicos mais significativos na região foram 0 ciclo do ouro e o da cultura de arroz como já mencionado. A área da serra do Quilombo onde está localizada as comunidades de 
Pilões e Maria Rosa é citada por Carlos Rath, em registro do Arquivo Histórico de São Paulo, 1833/1856, descrevendo a ocupação na região:

Os lavradores que viveram aqui para tirar o ouro mataram uns aos outros e porisso os brancos desapareceram e só os pretos se conservarão até hoje no ribeirão de Ovaporuduva, Anhanguera, Serra do Quilombo. Os lavradores d'ouro fugiram destes lugares tristes de lembranças tenebrosas [...] A serra do Quilombo foi em certo tempo o esconderijo de uma porção de escravos, todos lavradores d'ouro que matarão seus donos nas lavras dos pilões, Sant'Anna e das Mortes e acharão nestas serrarias auríferas um asilo... (RATH, Descrição da Região Fluvial da Ribeira de Iguape apud STUCCHI, 2005, p.151).

Um período de extrema violência, derivada não apenas da atividade garimpeira, mas também em resposta à condição escravista ocorreu na região do ribeirão de Pilões, em Nhunguara, Ivapurunduva e Serra do Quilombo. Houve rebeliões, mortes, fugas e a formação de quilombos, de onde se acredita ter originado a toponímia do lugar - serra do Quilombo - que, depois da expulsão da população indígena daquela região, foi certamente ocupada pelos negros (STUCCHI, 2005).

Há documentos que tratam a condição de negros aquilombados nas proximidades do rio Pardo, portanto na região das comunidades de Maria Rosa e Pilões. A seguir, o excerto de Ofício de 28 de setembro de 1863 é apresentado no qual o subdelegado da Polícia de Iporanga, João Paulo Dias, noticiava à presidência da província a existência de negros aquilombados:

Por informações dadas por alguns moradores do Rio Pardo do Districto desta Freguezia que, nos sertões do mesmo Rio distante d'esta vinte ou vinte e cinco léguas mais ou menos, sertões que divisam com o da Provincia do Parana, se achão aquilombados alguns escravos 
fugidos do Norte desta Provincia, he de necessidade destrui-los pois que do contrario torna-se mais perigoso e graves prejuizos, consta mais que para ali tem se dirigido alguns criminosos que talvez estejão reunidos, e como esta subdelegacia querendo ver se pode batel-os não podendo o fazer por ter de fazer algum dispêndio não so pela distancia como pelo perigo da viagem do Rio por ser caudaloso, embora os donos dos escravos tenhão que pagar as despezas, não se pode fazer por já ter acontecido com captura de alguns escravos nesta, os donos leval-os para mandarem pagar e nunca mais se lembrão que he devido a não se poder conserval-os na cadea desta Freguezia por não offerecer segurança e já por mais de huma vez tenho representado para remediar-se com esse melhoramento urgente ate hoje tem sido esquecido (Cadernos do Itesp 3, 2000, p. 98).

O mesmo documento ainda revela que a população local mantinha aliança com os negros aquilombados, não se podendo confiar à comunidade local a captura desses escravos:

Tenho de fazer lembrar a Vossa Excelencia que com gente do lugar não se pode fazer diligencia de tal natureza por ser perigosa e mesmo alguns avisão aos que se pretende capturar...

O que se pode concluir a partir de tal documento é que na região de Iporanga a fuga de escravos não era um acontecimento esporádico, mas sistemático. Nota-se, também, que essas buscas envolviam riscos e muitos esforços em consequência das dificuldades de acesso que a região apresentava em sua cofiguração geográfica. Outro ponto importante é o de que o isolamento dessas comunidades era relativo, pois eles mantinham com a população local laços afetivos, que poderiam ser explicitados como relações econômicas e sociais. Assim, não se poderia requisitar efetivos do local, por correr-se o risco de que estes 
alertassem os negros fugidios antes que a polícia pudesse encontrá-los (Cadernos do Itesp 3, 2000, p. 99).

A comunidade de Maria Rosa encontra-se praticamente na frente da comunidade de Pilões, estendendo-se ao longo do rio dos Pilões ou ribeirão dos Pilões. A formação do bairro de Maria Rosa como comunidade negra e muito antiga pode ser constatada por meio de relato de Benedita Dias da Costa, moradora do bairro ao descrever a formação de sua família:

Essa passagem foi contada por José Gomes de lima para Benedita da Costa que sou eu que estou contando, que a minha bisavó era dos escravos e fugiu aqui para essa região, foi pega a laço e casou com Lutério, meu bisavô que também era daqui da mesma região, do qual nasceu Joaquim que casou com Antoninha minha avó, daqui também da mesma comunidade de Maria Rosa, da qual nasceu Maria minha mãe, que casou com José Gomes de Lima, meu pai, da qual nasceu três filhos e ela faleceu, deixando meu pai viúvo com todos nós pequenos, eu com treze anos, outro com oito.e um neném com um mês de idade, meu pai lutou para nos criar sozinho, e eu me casei com José Dias da costa, família daqui mesmo, descendente de quilombo, aonde nascemos e crescemos e estamos vivendo, nessa terra dos nossos antepassados e nunca queremos sair daqui porque ninguém tem experiência da cidade. Queremos cultivar a lembrança de nossos antigos (Caderno do Itesp 3, 2000, p. 102).

O depoimento de Renato Gomes de Nascimento relata a origem do denominativo da comunidade de Maria Rosa e entorno, descrevendo, inclusive, sobre uma localidade chamada Inveja que ainda hoje consta nos mapas locais. Pode-se também constatar que na região de Iporanga existiam fazendas de trabalho escravo, onde os negros fabricavam aguardente, farinha de mandioca e eram usados em serviços domésticos: 
A Inveja era do amo Diogo de Moura. Quando acabou a escravidão liberou a terra pros negros plantarem. O amo morava em Pilões, abriu aqui pros negros trabaharem. Tinha um ex-escravo chamado João Negro que veio morar em Maria Rosa com um monte de filhos. Então o lugar ficou conhecido como 'monte de negros', Montenegro. Maria Rosa deve ter chegado na mesma época que João Negro. O pai da minha mãe, Sebastião Gomes do nascimento, veio de Itapeúna. Veio de lá comprado, no tempo da escravidão. Itapeúna chamavase Jaguari Lá tinha uma fazenda de negros e no Caracol tinha outra. O fazendeiro era o mesmo Diogo de Moura. Desceu em Itapeúna e comprou a minha avó com o neguinho. Foram morar no Caracol. A mãe de Sebastião chamava-se Maria Proencia, ela é que foi vendida. Ali libertou os escravos, mandou ele se virar e cada um viver a vida como aprouvesse. Aí ficou o velho Sebastião, foi pra Inveja e casou com uma mulher Maria Naia, irmã de Chiquinho, que morava na Inveja também e era casado com Maria Romão. Depois que Maria Naia morreu, Sebastião casou com Catarina Dias Messias, da Inveja (Cadernos do Itesp 3, 2000, p.102).

Por meio dos relatos, nota-se que havia uma população negra não submetida às relações escravistas no entorno da Freguesia de Iporanga antes da abolição. Há documentos que comprovam também a existência de terras ocupadas por escravos e reconhecidas por seus vizinhos brancos:

(...) no lugar denominado São João, dos dois lados da Ribeira, a saber (...) divide (...) rio abaixo com terras de Geraldo de Pontes na barra de um córrego e dahi para uma gruta secca para o centro a encontrar com terras de João, escravo de Rodrigo Betim(...)" (9-12-1855 registro no 28, José Mendes Torres declarava posse de terras. In Cadernos do Itesp 3, 2000. P. 104).

Presume-se que a instalação das fazendas Santana, Jaguari e Caracol, na região de Iporanga, ocorreu tardiamente de acordo com relatos de moradores das comunidades de Pilões e Maria Rosa. A 
fazenda Santana ficava próxima onde hoje se localiza a comunidade de Pilões, ao lado da barra do rio Pilões. O topônimo Porto dos Pilões deriva do fato de que as embarcações descarregavam ali as mercadorias para abastecer a sede da fazenda e seus escravos. A fazenda Jaguari localizava-se entre a comunidade de Pilões e a cidade de Xiririca (hoje chamada de Eldorado). A única localizada junto de Iporanga era a fazenda Caracol. Essas fazendas não praticavam o garimpo segundo relato de moradores da região. A fazenda Santana produzia principalmente aguardente para comercializar o que implicava o plantio de cana de açúcar (Cadernos do Itesp 3, 2000, p. 105).

O mesmo processo de ocupação negra nas comunidades de Pilões e Maria Rosa pode ser aplicado a todo o Vale do Ribeira, onde brancos, negros libertos, escravizados e fugidios conviviam.

Presume-se que a atividade garimpeira no entorno de Iporanga tenha persistido por mais tempo em relação a outras localidades Ribeira abaixo. Esse fato pode justificar a preservação ambiental encontrada até hoje na região. A atividade do garimpo naquela época não interferia de forma agressiva no meio ambiente, diferente da atividade agropecuária em grande escala que exige a devastação de florestas.

Há, portanto, o reconhecimento de que o plantio de roças de subsistência praticado pelas comunidades quilombolas resultou na preservação da mata na região do Vale do Ribeira. O que há alguns anos era visto como retrocesso, passou a ser entendido, em especial pelos ambientalistas, como atividade realizada de forma sustentável que deve ser preservada para a subsistência das comunidades que vivem no entorno de Unidades de Conservação Ambiental (APAs), como é o caso do Petar na região de Iporanga. 
A produção de arroz no Vale do Ribeira foi bastante significativa no início do século XX. Os excedentes produzidos pelos pequenos produtores eram comercializados por barqueiros que subiam o rio comprando a produção previamente vendida para armazéns localizados às margens do Ribeira. A pequena quantidade do produto fornecida por esses produtores, resultado de suas roças de subsistência, alcançavam preços ínfimos, mas, em contrapartida, os proprietários de barcaças, em sua maioria de Iguape, aferiam lucros enormes, pois conseguiam uma quantidade propícia à comercialização em larga escala.

Roças de mandioca, milho, feijão e cana de açúcar também eram cultivadas pelos pequenos produtores da região do Vale do Ribeira e vendidas nos centros maiores, em especial Eldorado e Iguape.

A maneira como era feita a comercialização com os pequenos produtores negros é narrada por Ismael Júlio da Silva, proprietário de um desses armazéns situado na passagem da balsa para São Pedro, margem esquerda do rio há, aproximadamente, 25 anos atrás:

Eu atendia o pessoal dos bairros, comprava deles e revendia em Eldorado arroz, feijão, café, milho. Buscava os produtos nos bairros de canoa e burros,ia para Pilões, São Pedro, Ivaporunduva, Nhunguara. O outro negociante que tinha aqui era meu irmão Antonio Julio, mas eu comprava mais porque tinha mais e animal e canoa para comprar. lam dois camaradas por canoa para buscar, em cada canoa cabem uns trinta sacos de 50 quilos, e de animal eu tinha uns 12 ou treze burros (Cadernos do Itesp 3, 2000, p. 106).

Ismael Julio de Oliveira herdara de seu pai, José Julio da Silva, e de sua mãe, Nha Lena, o estabelecimento comercial que cuidou durante 50 anos. Além dessa atividade, relata que possuía 
uma olaria, plantava café e "tocava muito serviço, tinha muitas terras"). Em 1939, Edmundo Krug descrevia a viagem entre a barra e a nascente do ribeirão Pilões realizada em embarcações da viúva de José Julio, que oferecia também hospedagem aos viajantes ( $p$. 584 e 588). A família destacava-se na região pela superioridade econômica, o que ainda ocorre. Segundo João Maciel, José Julio, nascido no Vale e morrido em 1914, aos 80 anos, teria recebido terras como premio pela participação da Guerra do Paraguai onde "foi expedicionário, sorteado, como foram outros rapazes que tinham mais de 21 anos"). Após o término da Guerra, onde "outros morreram em combate, ele retornou para terra dele porque era forte, e montou loja". (página). Pelas estimativas do informante, José Julio, filho de uma negra chamada Maria Severina da Silva, nasceu por volta de 1830 , tendo na época da Guerra do Paraguai quase trinta anos. A participação como combatente nesse conflito foi uma das formas de acesso à terra possibilitada à população negra no Brasil. (Cadernos do Itesp 3, 2000, p.106)

2.3.3 Bombas é a comunidade mais isolada do entorno do Petar. Localiza-se dentro do Parque, ou melhor, o Parque, em sua formação, abarcou a comunidade. Situa-se no município de Iporanga, entre a serra do Sem Fim e os bairros de Praia Grande e Descalvado, próximo às comunidades de Porto Velho, Cangume e João Surrá.

O acesso à comunidade é complicado, não existe estrada e todo o percurso deve ser feito a pé ou em animais por uma trilha larga, mas bastante acidentada. Em dias normais, sem chuva, levase de uma hora à uma hora e meia de caminhada até alcançar o primeiro agrupamento de casas chamado Bombas de Baixo. Com 
mais uma hora de caminhada, chega-se ao outro agrupamento, chamado Bombas de Cima. Santos $(2010)^{24}$ relata que:

embora a Agenda Socioambiental aponte duas horas e meia como tempo de caminhada, nunca consegui fazer o trajeto em menos que três horas. Em uma ocasião, com muita chuva [...] levei cerca de cinco horas para completar a caminhada até Bombas de Cima.

Bombas está localizada em meio à Mata Atlântica, paisagem exuberante composta de mata virgem ou mata preta, como dizem os moradores ao se referirem à floresta não alterada (floresta primária). Há também, no entorno, terrenos com floresta secundária $^{25}$, capoeiras e as roças dos moradores. Não há nenhum rio volumoso, mas inúmeras nascentes de água pura que permite que todas as habitações tenham uma bica para uso doméstico e banhos. O curso das águas de Bombas de Cima tem sua vazão no Ribeira, os demais fluxos de água deságuam no córrego Bombas (SANTOS, 2010, p. 119).

A distribuição das habitações em Bombas segue o mesmo padrão de todas as comunidades da região, as casas são distantes umas das outras, todas tem espaço para o terreiro e a roça, compondo os sítios descritos no início do capítulo. As casas são de pau a pique, feitas com madeira da floresta, assim como os móveis usados na comunidade. Para cozinhar e aquecer suas casas, os moradores usam fogão à lenha feito de taipa, usando o termo taipa para se referir ao fogão (feito na taipa). A lenha é retirada da mata secundária da área circundante da comunidade (SILVEIRA, 2000, p.117).

\footnotetext{
${ }^{24}$ Maria Walburga dos Santos desenvolveu a pesquisa para sua tese de doutorado na comunidade de Bombas. Cujo título é Saberes da terra: o lúdico em Bombas uma Comunidade Quilombola (estudo de caso etnográfico), tese apresentada a Faculdade de Educação da Universidade de São Paulo, em 2010. ${ }^{25}$ Floresta secundária é aquela que resulta de um processo de regeração natural em áreas de floresta primária que foram totalmente desmatadas.
} 
É comum que as famílias criem animais de pequeno porte como galinha, patos, porcos e cabras em seus quintais. Também possuem um ou dois burros ou cavalo para o transporte. Usam o hiperônimo animal para designar esses animais de carga em contraposição aos de pequeno porte que são denominados por seus respectivos nomes (hipônimos).

A denominação Bombas de Baixo e Bombas de Cima está relacionada à situação do relevo e serve para orientar as pessoas de fora da comunidade, para os moradores há um recorte mais complexo do bairro: Cotia refere-se a Bombas de Baixo; Cotia Grande, Lagoa, Mona, Paca, Roncador e Córrego Grande referemse a Bombas de Cima (ISA, Agência Socioambiental, 2003, p.125). Para quem não é do bairro, o nome Bombas é suficiente para nomear a comunidade. Tanto é assim que o laudo do Itesp (Instituto de Terras do Estado de São Paulo) refere-se à Bombas como uma unidade.

As escolas do bairro de Bombas deixaram de funcionar no ano de 2012. Havia uma escola municipal (da pré-escola até a quarta série do ensino fundamental) em Bombas de Baixo e outra em Bombas de Cima. Em Bombas de Cima existe uma igreja católica em ruínas, um pequeno campo de futebol, um posto de saúde desativado e várias casas próximas. Não há energia elétrica nem rede de telefonia, as duas comunidades utilizam lampiões ou velas para iluminação e pilhas para abastecer os rádios dos moradores (ISA, Agência Socioambiental, 2003, p.127).

De acordo com Silveira (2001), o topônimo Bombas além de designar a comunidade como um todo também se refere aos lugares onde residem Dona Davina e Dona Virgilina, moradoras antigas da comunidade de Bombas, correspondendo, respectivamente, a Bombas de Baixo e Bombas de Cima. Nesse 
estudo, observou-se um dos aspectos característico do universo denominativo do entorno do Petar: há um número significativo de antropônimos que remetem não a pessoas que não participaram da dinâmica do lugar, mas a atores locais, atores no sentido daqueles que interagiram ou atuaram de maneira significativa com a comunidade, portanto o resgate desses nomes ajuda na reconstrução dos traços étnico-culturais da comunidade local.

O caso dos nomes de Dona Davina e Dona Virgilina sugere um percurso gerativo que resultaria no surgimento de dois topônimos que acabariam por referencializar o lugar em que cada uma delas vive, isto é, Bombas de Baixo e Bombas de Cima, mostrando a importância desses atores na constituição do ethos comunitário. Hoje, esse percurso não se materializaria mais, as relações da comunidade com o lugar mudaram substancialmente. O regime de trocas, um traço que fora bastante comum nas comunidades do Alto Ribeira, já não acontece com a mesma naturalidade que ocorriam há alguns anos atrás. Mesmo as reunidas (formas de trabalho coletivo, como a limpeza dos caminhos, ou, para fins individuais, tais como a construção de uma casa ou a derrubada de uma capoeira. Quando o fim é coletivo não se espera nenhum tipo de pagamento, mas quando o fim é individual paga-se com uma refeição e espera-se que, quando o outro morador for fazer uma reunida o morador beneficiado compareça)e os puxirões (é uma modalidade de reunida, um trabalho coletivo, que é recompensado com um baile, ou seja, festa acompanhada de sanfona, comida e bebida) típicos na região, dificilmente acontecem nos dias atuais. Há um esvaziamento dos bairros, pois os mais jovens raramente ficam para ajudar a família em suas roças, saindo à procura de estudo e não voltando para se estabelecer e trabalhar com a família na terra. 
Os primeiros sinais de ocupação permanente na área de Bombas datam do começo do século XX, ligada a escravos fugidios e descendentes de portugueses que ocupavam uma área próxima, conhecida como Fazenda Furquim. Os nomes Mota e Ursolino, descendentes de famílias da comunidade de Nhunguara, no município de Iporanga, também chegaram nessa mesma época.

Pessoas vindas de Minas Gerais, como foi o caso do senhor Celestino Muniz e de comunidades próximas, como Porto Velho, Três Águas, João Surrá, que fica do lado do Paraná, também se instalaram na região nessa mesma época (Agência Socioambiental, 2008, 125).

De acordo com a narrativa de moradores de Bombas, colhidos por Silveira ${ }^{26}$, entre os anos de 1920 e 1930, chegaram descendentes da família Furquim, vindos da Fazenda de mesmo nome, próxima ao Lajeado. Essa família se distinguia dos demais moradores pela cor de sua pele, eram reconhecidos como vermelhos ou mesmo brancos. Nessa época, também chegou Gregório de Almeida e sua família, lembrados ainda hoje como escuros. Seu primo Gonçalo de Almeida habitou o Pinheirinho, morro que faz a divisa entre Bombas de Baixo e Bombas de Cima (Silveira, 2003 apud SANTOS, 2010, p.121).

A partir de 1935, chegou à região, vindo da comunidade de João Surrá, do lado do Paraná, membros da família Peniche, que ainda hoje tem seus descendentes vivendo na comunidade, na região de Cotia (Bombas de Baixo). Vieram também famílias do quilombo de Praia Grande. Hoje, a rede de parentesco existente em Bombas é formada pelas famílias Dias Peniche, Peniche de

\footnotetext{
${ }^{26}$ Pedro Castelo Branco Silveira redigiu o Relatório Técnico Científico da comunidade de Bombas para o Itesp no ano de 2003.
} 
Matos, Dias Marinho, Ursolino e Munis (ISA, Agência Socioambiental, 2003, p.125).

A constituição de Bombas de Baixo foi formada por dois ramos distintos, que não se misturaram aos Furquim (mais claros) e aos Ursulinos (negros). Com o tempo, os moradores de Bombas de Baixo e Bombas de Cima passaram a interagir e criaram vínculos de parentesco. Hoje, a conformação do bairro é predominantemente negra, mas há brancos, pardos, descendentes de índios, enfim todas as tonalidades que caracterizam a origem mestiça brasileira (SANTOS, 2010).

Essa mestiçagem, marca da identidade étnica brasileira, na região do Alto Ribeira, ainda está muito viva, ou como um fato real mesmo se considerar-se os testemunhos como relatos verídicos, ou míticos, o que importa é que ainda é parte do universo narrativo da população e, portanto, parte do imaginário do grupo.

Além dos casamentos com parentes e com outros negros já estabelecidos [...] ocorreram casamentos com mulheres que às vezes eram raptadas de populações indígenas. Nos bairros negros da região são inúmeros os relatos sobre antepassadas índias que foram pegas no laço (Carvalho apud SANTOS, 20010, p. 129).

Santos (2010) complementa com o testemunho de Irineu (Neu), morador de Bombas de Baixo,ao relatar que "sua avó era índia, que foi catada no laço pelo avô e depois de amansada, casou-se e teve filhos com ele."

Dona Antonia, moradora de Bombas, conta:

minha avó, minha tataravó, foi pegada a laço, ela era bugre sabe [...] então nós somo raça de índio, de índio, se criamo na roça, sabemo tudo o que fazê de roça, somo geração de índio ${ }^{27}$.

${ }_{27}$ Um Lugar chamado Bombas é um documentário filmado na comunidade de Bombas, em 2004, por Luis Flavio Terra Hungria. Disponível em http://vimeo.com/52203692 acessado em 04-07-2013. 
O denominativo Bombas, de acordo com depoimento de Clayton $\mathrm{Lino}^{28}$, tem como referência uma caverna da região chamada Ressurgência das Bombas que, diferente das outras cavernas do entorno não é um sumidouro, mas uma ressurgência de água. Nesta área, a água brota da montanha e, de tempos em tempos, ela parece estourar como se tivesse um lago subterrâneo que vai enchendo e chega em um determinado momento em que há um estrondo e a água sai. A população local se refere a esse local como a boca da bomba. (Silveira, 2000, p. 110).A caverna ainda não foi explorada. Na gruta Ressurgência das Bombas é que foi encontrado o bagre cego, símbolo do Petar.

Bombas está instalada em área de rochas calcárias como todo o Petar. Há, portanto, muitas cavernas na região. Iporanga é conhecida como a capital das cavernas. Antes da chegada dos espeleólogos (conhecidos como gruteiros) ao Petar, a população se referia às cavernas como buracos no solo, eles não tinham interesse em explorá-las. Somente depois da implantação do Parque e a chegada dos turistas é que a comunidade começou a se interessar pelas cavernas (SILVEIRA, 2000).

O Relatório Técnico Científico da comunidade de Bombas foi elaborado por Pedro Castelo Branco Silveira, em 2003. Em 2010, a comunidade foi reconhecida oficialmente como remanescente de quilombos. Atualmente, o reconhecimento do território e quais são os limites da comunidade está em processo de negociação definido em reuniões entre a comunidade e a Secretaria Estadual do Meio Ambiente.

O reconhecimento do território de Bombas foi um dos mais demorados da região do Alto Ribeira. Os fatores que dificultaram

\footnotetext{
${ }^{28}$ http://vimeo.com/52203692.
} 
esse processo, além dos aspectos intrínsecos à comunidade, estão relacionados à questão geográfica: no contorno definido pela comunidade há uma área de mata primária, ali também se encontra a bacia de captação de água do sistema Areias onde se localizam cavernas que suportam grande variedade de fauna cavernícula, inclusive a gruta Ressurgência.

Em 2012, em reuniões entre a comunidade de Bombas e a Secretaria Estadual do Meio Ambiente, foi acordado o território já totalmente desmembrado do parque. A expectativa, a partir de agora é de que a comunidade poderá contar com melhoras até então impossíveis de serem implantadas, em razão das restrições impostas por estar dentro de uma Unidade de Conservação. Estrada, energia elétrica e demais benefícios poderão ser planejados e reivindicados pela população ao poder público. A comunidade espera que com a regularização das terras e a melhora das condições de acesso o êxodo rural dos últimos anos, em especial entre os mais jovens que saem em busca de estudo ou serviço, cessará e os atrairá de volta, para morar em Bombas. Hoje, vivem na comunidade por volta de doze famílias ou, segundo Santos (2010), setenta e cinco moradores. No passado, contam os moradores que havia mais de 200 pessoas vivendo na região (SANTOS, 2010, p.127).

\subsection{Bairro da Serra}

Ah, a mais antiga é de quando veio uma senhora aqui [...] É, é a Prudência. Dona Prudência da Motta, é tataravó minha. Ela veio aqui, veio aqui do lado do Paraná, entrou na trilha e gostou do mato aqui, era tudo fechado, sertão. Então ela gostou, a baixa da aí ela gostou. (...) Ficou ela e o filho dela...ficou aqui, gostou, daí foi trazendo gente aqui do lado do Paraná que é mais perto, tinha trilha por baixo de mato, e foi trazendo algumas pessoas aqui. Tinha alguns índios aqui também então foi gostando dela, porque ela participa bem da minha família, então, foi gostando e aí foi aumentando as 
irmandade. Ela foi amansando os outros e aí foi trazendo família, e largou família que era o pai descendente a ela, e aí foi misturando a família, foi misturando e foi crescendo e daí foi aumentando (depoimento de Luzia, moradora antiga do bairro da Serra coletado em julho de 2000. In: SILVEIRA, 2000, p. 177).

Essa é a história da primeira moradora do bairro da Serra, contada por sua tataraneta, Dona Luzia. O nome Motta passou a ser o denominativo do local onde vivia a família de Dona Prudência. Ainda hoje a Serra dos Motta é topônimo na região.

O bairro da Serra localiza-se ao sul do Petar, ou melhor, incrustado ao sul do Petar. Também aqui a criação do Parque interferiu na configuração do bairro. O recorte de ocupação foi modificado e parte do bairro foi incorporada ao Parque. No passado, o recorte de ocupação era mais difuso, havia vários bairros menores, denominados Macacos, Couto, Lambari, Lagoa, Cateto, Sítio Novo, Passagem do Meio. Esse recorte ainda hoje é usado pelos moradores mais velhos ao se referirem a esses lugares.

De acordo com Lino (1980), a formação dos bairros na região do Alto Ribeira, em especial no Bairro da Serra, objeto de estudo de sua pesquisa, se iniciou após o ciclo do garimpo, quando a população, sem uma opção rentável que substituísse o garimpo, optou pela agricultura de subsistência, ocupando de forma desordenada os "vales, assentos e encostas pouco inclinadas, abrindo-se as capuavas".

As capuavas eram territórios familiares, onde se criavam animais domésticos e mantinham uma roça para o sustento da família, eventualmente o excedente era trocado ou vendido no povoado, na vila central. As barganhas também eram feitas com outras capuavas vizinhas, geralmente distantes um ou dois 
quilômetros umas das outras. Muitas delas acabaram transformando-se em bairro rurais, pelo crescimento natural das estruturas familiares e das relações de vizinhança.

Não raras vezes a denominação desses bairros identifica a família de origem (Serra dos Motta, Camargo de Cima etc.) e é comum existir um pequeno polo de cristalização definido por uma "casa grande" (residência do patriarca), pela capela e pela pequena praça onde se localizam várias atividades sociais como jogos e festas, sendo estas geralmente de cunho religioso (LINO, 1980. Bairro da Serra: Estudo sobre um bairro rural de Iporanga. Vale do Ribeira-SP) ${ }^{29}$.

Pontos de pouso e passagem de tropeiros também formaram bairros na região. Geralmente estavam localizados próximos à rede hidrográfica e à conexão de trilhas que dessem acesso às vilas e bairros.

Em sua gênese, o Bairro da Serra comporta essas duas características: foi um aglomerado de origem familiar e, também, ponto de passagem para o escoamento de minério e produtos agrícolas.

A história da formação do bairro da Serra se confunde com a história da formação de todos os bairros rurais do Alto Ribeira. Em um primeiro momento, está relacionado à exploração do ouro, com a região sendo área de abastecimento de alimentos para os garimpos na região de Iporanga e Apiaí. Depois, na fase de produção agrícola, acredita-se que ali foi o local de pouso para tropeiros que transportavam a mercadoria para o planalto. Em seguida, vem o transporte do minério de chumbo, usando esse mesmo percurso.

${ }^{29}$ LINO, Clayton. Trabalho realizado para a Disciplina "Bairros Rurais", ministrado pela Professora Doutora Liliana Langará do Departamento de Geografia da Faculdade de Filosofia Ciências e Letras da Universidade de São Paulo no ano de 1980 . 
Como bairro rural, sua formação está ligada à agricultura de subsistência em terras coletivas, não havia propriedade, as pessoas iam chegando e se apropriando do terreno. Como visto no depoimento de Dona Luzia, os primeiros a chegar traziam seus familiares e, assim, a comunidade crescia ligada por laços de parentesco.

Além dos Motta, fundadores do bairro, outra família também se estabeleceu na região, os Andrade. O que hoje é conhecido por Bairro da Serra, dividia-se em duas localidades a serra dos Motta e o Sítio dos Macacos, onde vivia a família Andrade. Grande parte dos moradores da Serra ainda descende dessas duas famílias.

Como já dito, a agricultura de subsistência praticada pelos moradores funcionava pelo sistema de trocas, portanto não havia necessidade de comprar muita coisa fora do bairro, quase tudo de que necessitavam era produzido na região. As casas eram de pau a pique e o fogão de barro ou taipa. Nos quintais, criava-se animais de pequeno porte e plantava-se uma horta; praticavam agricultura de coivara, a terra era muita e não havia ainda as restrições ambientais impostas pela implantação do Petar. A caça era comum na região e as atividades extrativistas, em especial a coleta do palmito, não tinham restrições. Nesse contexto, o comércio não se configurava como uma necessidade.

A chegada das mineradoras na região modificou as relações do homem com a terra e com o trabalho. $O$ trabalho assalariado mudou a maneira como a comunidade se relacionava. A compra e venda de produtos passou a fazer parte da rotina do bairro.

Os bairros de Furnas, Lageado e Espírito Santo se formaram em função da mineração de chumbo, pois ali se localizavam as minas de mesmo nome. Desde o início do século $X X$, a atividade mineradora acontece na região de Iporanga. No início, o transporte 
do minério era feito por tropeiros que usavam as mesmas trilhas usadas pelos mineradores de ouro. Ao chegar a Iporanga, o chumbo seguia pelo Ribeira até Iguape e, dali, para o porto de Santos, destino final para a exportação:

Essas tropas inicialmente transportando minério (especialmente o chumbo de Iporanga) movimentavam um grupo humano relativamente grande que estabelecia uma dinâmica comercial nos pontos de parada para pouso e descanso. Estes pontos de parada normalmente coincidem com locais onde já houvesse posseiros instalados, ativando-se neles uma pequena venda e, os frequentes alambiques, tráficos de farinha, e moendas para fabrico de rapadura. Assim formaram-se inúmeros bairros rurais [...]. Neste último, (Iporanga) são exemplares os casos de bairros estabelecidos ao longo do Rio Betari (Serra dos Mota, Passagem do Meio, Bairro Betari, etc.) que no princípio se criaram baseados em capuavas e no crescimento familiar e só se desenvolveram devido ao contínuo movimento das tropas (Lino C. 1978, p. 5).

De acordo com Lino, essas paradas ao longo das trilhas deram origem a muitos bairros, sendo alguns deles identificados apenas pelos topônimos, pois não existem mais como locais de moradia, são referencializados pelos moradores mais velhos que, de alguma forma, participaram da dinâmica de formação do lugar.

A partir de 1936, o minério passou a ser beneficiado em Iporanga, na Usina do Morro do Chumbo, situada junto às jazidas no bairro de Caboclos, ao lado do bairro da Serra. No entanto, essa usina funcionou por pouco tempo (SANCHES, 2002). Naquele mesmo ano, foi inaugurada, também, a estrada que liga Iporanga a Apiaí, passando pelo Bairro da Serra. O objetivo da construção fora o de facilitar o escoamento do minério produzido na região. Para os moradores do Bairro da Serra, a abertura da estrada significou a oportunidade de buscar melhores condições de vida, procurando 
trabalho em regiões mais desenvolvidas. Segundo Lino, "a estrada mais do que uma porta de entrada representou uma porta de saída".

O processo de migração se agravou com o fim das atividades de exploração mineradora. A maioria dos moradores do Bairro da Serra tinha alguma ligação de emprego com as mineradoras ou em órgãos de prospecção. Com a perda dessa fonte pagadora, houve um retrocesso na economia da região, e o bairro voltou a ter um caráter predominantemente agrícola. Como consequência, o processo migratório aumentou muito. Nesse período de estagnação e decadência econômica, surgiu a primeira igreja evangélica que até hoje tem forte atuação na comunidade. Nessa época houve uma concentração da população ao longo da estrada.

Na década de 1960, espeleólogos franceses chegaram para explorar as cavernas da região e se hospedavam nas precárias acomodações do bairro, conhecido ainda como Betari. $O$ relacionamento dos exploradores com a comunidade local se limitava aos guias, moradores locais que melhor conheciam a região.

A energia elétrica, instalada em 1977, trouxe, naturalmente, melhoras nas condições de vida dos moradores. No entanto, somente com a introdução da atividade turística, quando o Petar foi demarcado e os turistas começaram a chegar, é que a paisagem do entorno começou a mudar. As casas, quase todas de pau a pique, foram substituídas por casas de alvenaria; o comércio foi incrementado; sugiram as pousadas e o desenho do bairro mudou, adquirindo uma paisagem quase urbana.

Os conflitos com a administração do Petar começaram a surgir nessa época, pois, até então, os moradores sabiam da existência do parque, mas as restrições não existiam, as 
mineradoras continuavam atuando, os palmiteiros não sofriam restrições em suas atividades, as roças de capuava se estendiam para dentro do Parque.

Com a demarcação dos limites do Parque, no início dos anos de 1980, todas as atividades foram coibidas. As mineradoras foram impedidas de atuar, as fábricas de palmito da região foram fechadas. Também foi nessa época que se percebeu que o parque cortava o bairro da Serra ao meio, pois as fronteiras do Parque foram pensadas levando-se em conta os acidentes geográficos, serras, vales, rios, cachoeiras, cavernas e a mata e não as demarcações do bairro.

A fim de minimizar o problema com a população, que repentinamente vira suas casas dentro do perímetro de uma Unidade de Conservação, a SUDELPA (Superintendência de Desenvolvimento do Litoral Paulista), dirigida pelo arquiteto e espeleólogo, Clayton Lino, em um acordo com os moradores, decidiu que o local das moradias seria excluído do perímetro do Parque, sendo anexada ao Parque uma nova área de igual ou maior tamanho em outro local. Essa decisão abriu o precedente para que outros conflitos dessa mesma natureza pudessem ser solucionados. Dessa maneira consolidou-se o contorno do Petar e nenhuma casa mais foi construída na área interna do Parque. (SILVEIRA, 2010, p.100).

Porém, a maioria das áreas de roça, onde a população local praticava a agricultura de coivara, ficou dentro do Parque, impossibilitando, assim, sua principal atividade de subsistência. Alguns moradores, bons conhecedores da região e que se relacionavam bem com as pessoas de fora, foram convidados a trabalhar no Parque; outros foram incentivados a construir pousadas para receber os turistas. Com o objetivo de criar opções 
de trabalho para os mais jovens e, assim, ajudá-los a se apropriar das oportunidades que surgiam, foram ministrados cursos de monitores ambientais para que pudessem atuar como guias junto aos turistas.

As transformações no Bairro da Serra pela implantação do Parque foram grandes e rápidas. No Parque, foram construídos os núcleos de visitação, privilegiando o nome da caverna mais importante da área: Núcleo Santana e Núcleo Ouro Grosso, próximos ao bairro da Serra, Núcleo Caboclos e Núcleo Casa de Pedra, mais distantes.

Com o aumento de turistas ocorre, também, a especulação imobiliária: moradores vendem seus terrenos para pessoas de fora da região, pois tinham a expectativa de que, com o dinheiro, pudessem conseguir uma vida melhor em outra região:

A chegada repentina de tantos turistas, como se pode imaginar, trouxe inúmeras consequências para os moradores do bairro da Serra. Uma das primeiras foi a venda das terras. Com títulos regularizados, no início do boom do turismo, muitos moradores venderam seus terrenos para gente de fora, pessoas estas com interesses diversos: uns com intenção de morar no local, a maioria de fazer casa de veraneio, e uma minoria ainda com a intenção de montar negócio no local (SILVEIRA, 2001, p. 73 apud FOGAÇA, 2008, p. 35).

Essas mudanças ressignificaram as relações da população com o ambiente. De comunidade tradicional ${ }^{30}$ que tinha a natureza como provedora do sustento e de todas as suas necessidades por meio da exploração de seus recursos, passam, agora, a agir como

\footnotetext{
${ }^{30}$ Comunidades tradicionais são grupos culturalmente diferenciados e que se reconhecem como tais, que possuem formas próprias de organização social, que ocupam e usam territórios e recursos naturais como condição para a sua reprodução cultural, social, religiosa, ancestral e econômica, utilizando conhecimentos, inovações e práticas geradas e transmitidas pela tradição Sistema Nacional de Unidades de Conservação - SNUC, artigo 3(SILVEIRA, 2010).
} 
guardiões do meio natural. Sua função seria o de preservar o meio ambiente e se apropriar do turismo como meio de subsistência. Deixam, portanto, de ser mateiro, agricultor, ou minerador, e passam a ter a função de monitor ambiental, proprietário de pousada, cozinheira, funcionário do parque, entre outras atividades relacionadas ao turismo.

\subsection{Petar}

O Parque Estadual Alto Ribeira está localizado ao sul do estado de São Paulo entre as cidades de Iporanga e Apiaí, em uma região serrana de Mata Atlântica protegida. Abriga um dos maiores contingentes espeleológicos do Brasil.

O Petar foi criado no ano de 1958, pelo Decreto Lei no 32.283 , por iniciativa do engenheiro de minas José Epitácio Passos Guimarães, do Instituto Geográfico e Geológico do Estado de São Paulo, quem, em 1957, propôs a criação de uma Unidade de Conservação para proteger as cavernas e a mata. No início, foi denominado PEAR, Parque Estadual do Alto Ribeira, mas, em 1960 a denominação do Parque muda para Petar, de acordo com a Lei 5973, fortalecendo seu caráter turístico e tornando suas terras inalienáveis e de conservação perene. No entanto, somente no final da década de 70 e início da década de 80 é que aumenta, de fato, a preocupação em torno do Petar e região.

A área do Parque não foi demarcada na época, continuava em completo abandono, apesar da mobilização e da proposta de estruturação de uma comissão administrativa que incluía também o Instituto de Botânica (FIGUEIREDO, 2010)².

\footnotetext{
${ }^{31}$ FIGUEIREDO, Luiz Afonso Vaz. Cavernas como Paisagens Simbólicas. Tese de doutorado. São Paulo, USP 2010.
} 
Visando proteger o patrimônio espeleológico e incluir as cabeceiras dos rios que constituíam importantes sistemas de cavernas, foi encaminhada, em 1983, pelo Condephaat uma proposta de tombamento do Petar e de áreas adjacentes pela importância para pesquisas científicas e com o intuito de preservar a bela paisagem natural. Essa medida foi efetivada com 0 tombamento de toda a serra do mar (incluindo a serra de Paranapiacaba) e declarada como área de Proteção Ambiental, APA Serra do Mar (KARMANN, FERRARI, 2002).

O Petar conta com uma área de 35.712 ha de Mata Atlântica preservada, banhada por rios encachoeirados que sustentam a paisagem natural e o complexo ambiente das cavernas. São três bacias que irrigam e mantém a paisagem do parque, a bacia do rio Betari, a bacia do rio Iporanga e a bacia do rio Pilões.

A mata exuberante do Petar é, predominantemente, formada por floresta ombrófila (ou floresta fluvial tropical), densa sobre solo cárstico $^{32}$, compondo o maior representante de tal variedade de floresta do país. Essa formação é muito relevante e peculiar ainda mais por ser floresta madura com grandes espécies emergentes, diferente da aparência de formação aberta que a ocorrência de solos calcários causa (Fundação Florestal/Instituto Florestal, 2010).

Para enfrentar o problema do desmatamento causado pela extração ilegal de madeira e palmito, nos anos de 1987 e 1988, os limites do parque foram demarcados em campo sob a responsabilidade do Instituto Florestal, órgão da Secretaria do Meio Ambiente do Estado de São Paulo que administra o Petar. Também

\footnotetext{
${ }^{32} \mathrm{O}$ termo karst significa campo de pedras calcárias e tem origem em uma região ao norte do Mar Adriático, na antiga Yugoslávia, onde se desenvolveu o primeiro estudo sobre a circulação de água em rocha calcária. O conceito de karst está relacionado ao relevo de regiões onde predominam essas rochas, nas quais a drenagem se faz preferencialmente pelo subterrâneo e sobressaem macro e micro formas de relevo bem peculiares, conhecidas como "formas cársticas". Clayton Lino, 1978,p. 45.
} 
nessa época, deu-se início à fiscalização do parque pela Polícia Florestal do Estado. A demarcação e a vigilância policial significou um grande avanço para a preservação do patrimônio natural.

O Vale do Ribeira não era uma região desabitada, como já visto anteriormente, foram identificadas evidências arqueológicas na bacia do rio Betari que comprovam que desde os tempos précoloniais esse vale era uma rota de comunicação entre a Baixada do Ribeira e o Planalto Atlântico. Essa rota também foi utilizada, no século XVI, pelos primeiros exploradores do Vale do Ribeira em busca de recursos minerais no planalto, em especial o ouro (De Blasis e Robrham apud KARMANN, 2002).

Foi Richard Krone quem primeiro investigou as cavernas do Alto Ribeira em busca de material paleontológico, arqueológico e informações etnográficas. Naturalista de origem alemã, chegou ao Brasil em 1884, e se instalou em Iguape. Seus relatos foram publicados em 1914 pela comissão Geográfica e Geológica sob o título Exploração do Rio Ribeira do Iguape.

Em 1950, em um novo relato, Krone descreveu a descoberta de quarenta e uma cavernas e a descoberta de ossadas que remetem à megafauna pleistocênica (entre 1,8 milhão a 11 mil anos atrás), reiterando o possível veio turístico e a beleza natural da região.

A partir dos anos sessenta, tem início a exploração sistemática das cavernas do Petar. Grupos ligados à Sociedade Brasileira de Espeleologia (SBE) e os técnicos do Instituto Geográfico e Geológico ${ }^{33}$ realizam os primeiros mapeamentos das cavernas. Guimarães e LeBret publicam, em 1966, Grutas Calcáreas: Estudo Espeleológico no Vale do Alto Ribeira.

\footnotetext{
${ }^{33}$ Atual Instituto Geológico da Secretaria do Meio Ambiente do Estado de São Paulo.
} 
As trilhas são os caminhos do Petar e é por elas que se entra em contato com a mata exuberante, a fauna rica, em especial os pássaros. O canto da araponga é típico na região, ao chegar-se próximo a Iporanga e visualizar a paisagem serrana coberta pela mata, o som do canto estridente da araponga marca as boasvindas ao Petar. Pelas trilhas, alcança-se as cachoeiras escondidas no meio da mata e são elas também que conduzem ao atrativo turístico mais procurado: as cavernas.

É uma experiência única entrar em uma caverna, em especial as cavernas do Petar, que estão entre as mais belas do mundo. Atualmente são conhecidas mais de 200 cavernas na região e ainda há a perspectiva de outras mais serem descobertas.

Com relação ao Parque, ele está estruturado em quatro núcleos de visitação. O Núcleo Santana localiza-se no vale do rio Betari, é composto por cinco cavernas. Dispõe de equipamentos de apoio como guarita, centro de visitantes com lanchonete e venda de artesanato típico da região, sanitários e estacionamento. A caverna Santana, que dá nome ao núcleo, é uma das maiores e mais ornamentadas cavernas do estado, com 5.040 metros de extensão. A gruta Morro Preto, com 832 metros, está localizada no lado oposto do rio Betari. É constituída de grandes salões, sendo percorrida pelo ribeirão Morro Preto. Na entrada dessa caverna, encontra-se um sítio arqueológico escavado por Krone no final do século XIX.

A terceira é a caverna do Couto, com 471 metros de extensão, o percurso na caverna é feito por entre blocos e cascalhos e termina em uma entrada ampla, o sumidouro do córrego do Couto.

Após caminhar por 1.300 metros pela bela trilha do rio Betari, chega-se à Caverna Água Suja. Esta caverna é bem ornamentada, na qual se destacam as estalactites, os mármores travertinos e a 
cachoeira no trecho final do percurso de visitação; tem uma extensão de 2.900 metros. Na mesma trilha do rio Betari, encontrase a gruta do Cafezal, que possui vestígios arqueológicos, com 216 metros. É formada por uma só galeria, sem drenagem perene, com grande salão no final de onde é possível avistar a luz do sol entrando através da cavidade.

O núcleo Ouro Grosso está localizado próximo ao bairro da Serra, no vale do rio Betari. Conta com um centro de visitantes, espaço para exposições e ou reuniões, banheiros e outras facilidades. Duas cavernas compõe o núcleo, ambas na margem esquerda do rio Betari. A caverna Ouro Grosso, com 1.100 metros de extensão, é uma caverna que apresenta grande dificuldade de percurso em seus condutos, com lances verticais, uma rede intricada de abismos e rio encachoeirado. A caverna Alambari de Baixo é bastante ornamentada, tem 755 metros de extensão, sendo sua maior atração a travessia de um rio com teto baixo, junto à ressurgência da cavidade.

O Núcleo Caboclos, localizado mais ao norte do parque, em uma região de planalto e altitude mais elevada, conta com estrutura para camping e o acesso se dá por Apiaí. As cavernas desse núcleo estão divididas em dois blocos Caboclos I e Caboclos II.

Caboclos I é formado por quatro cavernas pequenas, próximas umas das outras. Segue-se a trilha do Chapéu para alcançar as cavernas. As grutas do Chapéu Mirim I e II são de fácil acesso com extensão de 70 metros cada uma. A mais conhecida é a gruta do Chapéu, com 300 metros de extensão, é muito ornamentada com estalactites, estalagmites, represas de mármore travertino e um grande escorrimento chamado Cogumelo. No trecho final da cavidade, destaca-se o contato entre o calcário e o granito que forma a Serra da Dúvida, mais evidente no trecho final 
da caverna Aranhas que apresenta uma galeria de rio meandrante com alguns trechos com teto baixo e percursos por dentro da água com 210 metros de extensão.

Caboclos II é constituído por quatro cavernas: a caverna Pescaria com 2.780 metros de comprimento; a Desmoronada, 1.260 metros, as duas ricamente ornamentadas; a caverna Desmoronada que apresenta umas das maiores colunas do mundo, e a Termimina I e II.

A caverna Temimina II, com 1.969 metros de extensão, é formada por dois níveis. No superior, há galerias fósseis que se conectam com a galeria do rio por meio de desmoronamentos e divide-se em dois conjuntos de amplos salões separados por imensas claraboia que permitem a entrada de luz e a manutenção de vegetação formando verdadeiros jardins. O nível inferior é formado por ampla galeria com 20 metros de largura e formação de rara beleza, com destaque para a coluna de travertinos na coloração creme e o chuveiro (espeleotema com água que jorra de forma contínua por fraturas da rocha calcária). A caverna Temimina I tem apenas 52 metros de extensão, chega-se a ela descendo o rio e é constituída por conduto de grande dimensão e percorrido pelo rio Temimina.

O Núcleo Casa de Pedra fica no vale do rio Iporanga. É composto por cinco cavernas, sendo a principal a caverna Casa de Pedra com 5.500 metros de desenvolvimento linear. Apresenta o maior pórtico de caverna do planeta no sumidouro do rio Maximiliano, afluente do Iporanga. Em alguns trechos, o rio que entrecorta a caverna apresenta-se encachoeirado, próximo às entradas, e com corredeiras e remansos, ao longo da galeria de rio. Destaca-se o salão Krone, com entrada superior e bem próximo à entrada Santo Antonio com entrada ampla e claraboias superiores. 
Nesse roteiro de visitação, encontra-se as grutas Mojolinho, com 1.138 metros de extensão, e a gruta Arataca com 384 metros. Nesse grupo, destaca-se a ampla entrada superior da gruta Arataca e o conjunto de espeleotemas da Monjolinho.

A gruta Espírito Santo está localizada próxima a uma pedreira desativada, a 4,5 km ao sul do Núcleo Caboclos, e possui 250 metros de extensão. A caverna Água Sumida apresenta 298 metros de extensão com entrada principal alta e estreita. $O$ percurso interno na caverna é formado por conduto alto e salões amplos, com corredeiras e cascatas ao longo do rio Maximiliano, o mesmo rio que percorre a caverna casa de Pedra. O sumidouro do rio possui um perfil de galeria bastante entalhado. Destaca-se 0 conjunto de espeleotemas na porção central da caverna.

O crescente fluxo de visitação turista na região, sobretudo nos finais de semana e feriados prolongados, pode acarretar em impactos negativos, em especial no Núcleo Santana e Ouro Grosso, os mais frequentados em função de suas estruturas, constituindo riscos à conservação dos ambientes cavernícolas e à qualidade dos recursos hídricos, pois se trata de uma paisagem de forte fragilidade potencial. Tal fato contrariaria o motivo da existência do Parque que seria a conservação da riqueza e beleza local.

Com o objetivo de minimizar tais impactos, criaram-se cursos de formação de monitores ambientais, dando prioridade à população local, em especial os jovens, conhecedores do ambiente natural e da cultura local. Esses cursos priorizam a formação global dos jovens, não só em relação aos conhecimentos relacionados à estrutura física do parque e os ambientes de visitação, cavernas, trilhas, cachoeiras, ou, como receber e acolher o turista, os cursos visam principalmente a formação pessoal desses jovens. 
Nesse sentido, a comunidade local tem se apropriado dos benefícios gerados pelo afluxo de turistas ao parque, tornando-se essa a maior fonte de renda dos moradores da região de Iporanga, pois a maior parte do município constitui-se de área protegida.

Dizer que a região do Vale do Ribeira é a que detém o menor IDH do estado de São Paulo não significa que a população local, em especial os mais jovens, cofigurem um quadro de pobreza generalizada. A simplicidade da vida na região não significa necessidades materiais alarmantes. $O$ ambiente local e a integração com a natureza faz que os jovens se compreendam como possuidores e conhecedores de um ambiente natural e cultural único em suas características, ambiente mundialmente reconhecido como de grande valor.

\subsubsection{Análise da estrutura denominativa do Petar}

A região do Petar conta com uma ocupação muito antiga como foi visto anteriormente. Serão analisadas as camadas denominativas, levando-se em conta os aspectos diacrônicos da denominação do Petar.

A primeira camada seria a camada pré-colonial. Não há dados que garantam que esses topônimos sejam, realmente, nomes que já existissem antes da chegada dos europeus à região. Mas, conhecendo a historiografia local, é de se supor que muito dos nomes de rios e acidentes geográficos sejam denominativos autóctones.

Como já visto, a região do Alto Ribeira não era uma região desabitada, apesar de sua conformação geográfica de difícil acesso, há registros arqueológicos que comprovam que a região do vale era uma região de trânsito entre o litoral e o planalto, bem antes da chegada dos europeus. Pressupõe-se que todo o território 
já estivesse totalmente denominado, inclusive a flora e a fauna já eram conhecidas por seus nomes. As populações indígenas mantinham um íntimo convívio com a natureza, suas vidas estavam inteiramente vinculadas ao ambiente natural tanto aos aspectos físicos quanto aos culturais.

Pode-se concluir, portanto, que muitos desses denominativos de origem indígena sejam topônimos remanescentes dessas comunidades que habitavam e ou circulavam a região.

O Peabiru, rota indígena, mitológica, que ligava o litoral ao território andino, em um de seus possíveis percursos passava pelo Petar, na região hoje conhecida como Núcleo Caboclos. Se de fato essa rota existiu, pode-se supor que a região conviveu com várias etnias que poderiam ter deixado registros nos denominativos da região.

A maior parte dos nomes de rios da região é de origem indígena tupi: rio Betary, rio Yporanga, rio Bocó, rio Itacolomy, rio Cachimba, rio Taquari, ribeirão Moquém, rio Nhunguara, rio Xiririca, rio Apiaí Guaçú, rio Taquari Mirim, rio Tijuco, rio Temimina, ribeirão Brejaúva, rio Taquari Guaçú, rio Taquaruvira.

Encontram-se, também, serras com denominativos de origem indígena e esses também podem ser nomes que remetem ao um período pré-colonial: serra de Paranapiacaba, serra Gurutuba e serra Manduri.

As etimologias e a classificação taxionômica serão analisadas no capítulo em que se trata da metodologia.

Palavras como tipiti, coivara etc., de uso frequente ainda hoje na região, podem ser remanescentes dessa época por serem lexias do vocabulário indígena.

A segunda camada estaria relacionada à chegada dos europeus, data do início século XVI. Sabe-se que os primeiros 
exploradores chegaram à região entre 1502 e 1510. Como já mencionado anteriormente, Martim Afonso de Sousa, chefe da primeira expedição colonizadora, chegou ao litoral sul em 1531 e ali encontrou portugueses e espanhóis degradados ou náufragos, entre eles Diogo Álvares Correa, o Caramuru. Portanto, a partir dos primeiros anos dos 1500 , a influência da religiosidade começa a aparecer nos denominativos de lugar.

Na região do Petar, há nomes como o Garimpo de Santo Antonio, o primeiro nome de núcleo colonial da região com registro historiográfico datado de 1576. Encontra-se igualmente, topônimos como córrego Santana, rio Santo Antonio, rio São José do Guapiara, ribeirão São Pedro e rio São Sebastião.

A cidade de lporanga, em seus primórdios, teve, também, agregada a seu nome o nome da padroeira, o que era muito comum na época: Villa de Sant'Ana de Iporanga; Vila de Santo Antonio das Minas de Apiahy, o primeiro denominativo de Apiaí.

A terceira camada seria referente aos denominativos da população que ocupou o território e ali se estabeleceu. O lugar passou a ser vinculado ao nome de seu morador mais antigo. Essa camada solidifica a apropriação do espaço pelo homem, a consolidação do homem ao território. É o brasileiro que surgia dessa mistura do indígena, do português e do negro. A perspectiva agora é a do morador, de quem vive no lugar. Tem-se o bairro dos Camargos, a serra do André Lopes, a serra dos Motas e a serra dos Caboclos.

O mesmo homem que deu seu nome ao lugar também o denominou de acordo com sua percepção do espaço e da natureza: serra dos Macacos, Laje dos Macaquinhos, serra da Anta Gorda, etc. Nota-se que o processo metonímico, a relação de contiguidade explícita na a parte que passa a representar o todo, é 
usado tanto pelos indígenas como pelos não indígenas. A configuração do lugar é descrita levando-se em conta a paisagem local, transformando o papel referencial do topônimo em um índice e/ou ícone. De acordo com a teoria de Pierce, um ícone pode representar seu objeto principalmente por sua similaridade, não importando qual seja seu modo de ser. Já o índice depende de uma associação por contiguidade e não de uma associação por semelhança (PIERCE, 2008).

A quarta camada denominativa do entorno do Petar abrange um período que vai dos anos de 1920 até por volta do início dos anos cinquenta do século passado, quando os primeiros pesquisadores, a maior parte deles estrangeiros, chegaram para explorar a região, em especial as cavernas. Ligados aos órgãos oficiais, tinham o propósito de definir e delimitar as fronteiras na região. Sigismund Ernst Richard Krone e Edmund Krug são os dois pesquisadores que primeiro descreveram a região e seu potencial turístico. Esses exploradores tinham o conhecimento e detinham o controle dos mapas oficialmente. Nomeavam como queriam, muitas vezes não levando em conta os denominativos já estabelecidos na região, criados pela comunidade local ou, mesmo, existentes antes dessas comunidades. Pode-se crer que alguns recortes denominativos significativos no contexto da configuração geográfica possam ter se perdido nessa época.

As cavernas não tinham nomes, os moradores locais não costumavam explorá-las, sendo Krone o primeiro a denominar as cavernas da região do Petar. A Caverna de Santana, denominada por Krone, Caverna do Roncador, em função do nome do rio que passa pela caverna e faz um forte barulho parecido com um ronco, foi descrita por ele, em 1909, e identificada como número 41, em 
uma lista de cavernas conhecidas no estado de São Paulo na época.

Nos final dos anos trinta, por volta de 1939, um grupo de japoneses arrendou o Morro do Ouro, em Apiaí, na região do Petar, para exploração do ouro de forma industrializada, mas, em 1942, as atividades foram encerradas com o início da guerra. Não há registro de que esse grupo de estrangeiros tenha interferido na nomenclatura da região. Fato interessante, pois um grupo poderoso financeiramente, explorando ouro, poderia ter deixado ao menos um denominativo marcando sua passagem pela região, região que na época era ainda pouco explorada e habitada e, portanto, com grande potencial para ações denominativas. Como diz NobergSchulz, é preciso ser parte do lugar, descobrir o genius loci da paisagem para interferir e ser parte dela. Provavelmente, esse grupo não se apropriou do ambiente.

A partir da década de 1960 e até o início dos anos oitenta, uma nova camada denominativa é encontradas. Nessa fase, predominou a exploração das cavernas por pesquisadores e estudiosos estrangeiros, em sua maioria franceses, vindos ao Brasil especificamente para explorar as cavernas, os espeleólogos. O grupo de Pierre Martin, o mais significativo dessa época, denominava as cavernas em uma auto-homenagem ou a homenagem aos outros participantes do grupo, não levando em consideração a história da comunidade que ali vivia. Como já ocorrera antes, esse grupo se relacionava apenas com os guias locais que eram os grandes conhecedores da região. Predominou a visão do conquistador no ato de nomear: abismo do Colet, abismo do Philip, abismo do Jandir, gruta do Joaquim Justino etc.

Outro momento dessa fase são os denominativos modificados por interesses políticos e/ou econômicos. O poder público é quem 
nomeia: a gruta da Tapagem passa a ser denominada caverna do Diabo, o nome original estava relacionado ao nome do rio que percorre a caverna e o segundo, atribuído ao secretário de turismo da cidade de Eldorado, tinha como único o objetivo o de atrair turistas. A Gruta do Roncador, uma das mais bonitas do Petar passa a ser chamada caverna Santana. Renomeada pelo prefeito de Iporanga, tinha também o objetivo de atrair turistas ao relacionar o nome da caverna ao nome da santa padroeira de Iporanga. Não se pode negar o papel dos denominativos de lugar na construção midiática, o nome de lugar é um fator decisivo na composição do imaginário geográfico.

As modificações por imposição do poder público foram, também, por motivos turísticos. Por exemplo, o nome Pear que teve o t incluído para abrigar o termo "turístico" ao acrônimo.

Até o início dos anos 1990, os espeleólogos e pesquisadores, ao se referirem ao Petar, diziam Betary, ou vale do Betary. lam ao rancho do Betary, onde hoje é a pousada da Diva, a mais antiga e conhecida pousada da região do Petar. O nome Petar só se consolidou como referencial do parque quando, de fato, se complementou sua estruturação: quando o parque, com seu potencial turístico, passou a ser conhecido e procurado pelos mais variados grupos com suas diversas motivações.

A Serra dos Motas, hoje Bairro da Serra, possuía um recorte mais detalhado da região, tinha-se a serra dos Motas, o morro dos Macaquinhos e a Laje Branca, delineando o que hoje é conhecido simplesmente por bairro da Serra, como já mostrado no item com o mesmo nome. O recorte detalhado ainda está na memória dos moradores mais antigos. A dinâmica do lugar mudou e a nomenclatura acabou acompanhando essa dinâmica. Os moradores mais novos já não identificam esses pontos no mapa 
local. Uma nova configuração do lugar se constituiu com a toponímia acompanhando esse movimento.

A última camada denominativa aconteceu em meados dos anos de 1970 até os noventa e está relacionada aos jovens universitários que chegaram à região com a finalidade de desenvolver suas pesquisas em geografia, física, antropologia, biologia, arqueologia, etc. Esses jovens pesquisadores tinham uma relação muito próxima com a comunidade local, portanto, o ato denominativo leva em consideração as características do local, respeitando o fazer toponímico da região.

Em 1975, os integrantes do CEU (Centro Universitário), durante a Operação Tatus (experiência de permanência subterrânea e cronobiologia de 15 dias realizada na Caverna de Santana), descobriram o Salão Taqueúpa, ícone de uma rede de galerias denominada Rede Tatus, reconhecida pela variedade e profusão de espeleotemas raros, delicados e de uma beleza invulgar $^{34}$. O caráter icônico do nome Tatus, um canal múltiplo que interliga várias galeria no interior da caverna, metaforizando os caminhos construídos pelos tatus.

Posterior a essa primeira turma de estudantes pesquisadores, um novo grupo de jovens, nem sempre pesquisadores, muitas vezes apenas a procura de aventura, passou a denominar as cavidades em função de si mesmos, sem vínculo com a comunidade ou com os fatos que referecializavam o entorno. Como exemplo, tem-se a Gruta de Los Três Amigos.

O universo das cavernas ainda está sendo explorado e denominado. Recentemente, um novo salão foi encontrado no interior da caverna Santana e denominado salão Pierre Martin.

\begin{tabular}{lllll}
\hline $34 \quad$ Grupo Pierre Martin de & Espeleologia & Disponível & em \\
http://www.blog.gpme.org.br Acessado em & 27 de abril de 2013.
\end{tabular} 
O mapa toponímico do Petar sofre novas configurações à medida que os moradores, os pesquisadores, os monitores ambientais e, também, os próprios turista vão desenhando e redesenhando novas paisagens no ambiente. Nesse sentido, o topônimo configura a territorialidade por excelência, isto é, o espaço que passa a ser lugar no momento em que é apropriado pelo homem. 


\section{Fundamentos Teóricos}

\subsection{A base do triângulo de Ogden \& Richards}

Ao entender-se a Onomástica como o estudo dos nomes próprios, considera-se a Toponímia e a Antroponímia como ramos desse estudo, a primeira responsável pelos nomes de lugares e a segunda, pelo nome de pessoas.

O topônimo pode ser compreendido como o vocábulo que estabelece a função semiótica entre o homem e a língua, entre 0 homem e o espaço, como também entre o homem e o tempo em uma concepção de linguagem especializada sincrônica e diacrônica.

As relações homem/língua, homem/espaço e homem/tempo são fundamentais para justificar a interdisciplinaridade nesse campo de estudo, não podendo ele ser pensado isoladamente. A interdisciplinaridade, portanto, é parte inseparável desse ramo de conhecimento. A possibilidade de intercâmbio entre as principais áreas de pesquisa da Toponímia, a saber, a Linguística, a Geografia, a História, a Antropologia e a Psicossociologia, é fundamental para a formação de uma visão holística do ser humano e das relações que este mantém com o mundo.

Não se pode, porém, deixar de caracterizar a autonomia da Toponímia como ciência. Como já foi visto, ela possui seus códigos e objetos próprios de análise.

A linguagem é, aqui, entendida como uma parte integrante da vida social. Partiu-se do pressuposto de Lévi-Strauss ${ }^{35}$ de que a Linguística está estreitamente ligada à Antropologia Cultural. Como sistema de signos, portanto, sistema semiótico, a linguagem

${ }^{35}$ LÉVI-STRAUSS,Antropologia Estrutural, 1970. 
estabelece relações intrínsecas com a cultura. E, como disse Benveniste $^{36}$, "nenhuma língua é separável de uma função cultural".

Procurou-se estudar o topônimo como unidade de língua, inserido nos princípios de classificação da Linguística, e como unidade cultural. Deu-se prioridade, na presente análise toponímica, a duas modalidades de aferição dos fenômenos de motivação, pois se entende serem essas as características que distinguem o topônimo no universo das linguagens, a saber:

1. primeiro, a intencionalidade que anima 0 denominador, acionado em seu agir por circunstâncias várias, de ordem subjetiva ou objetiva, que o levam a eleger, em um verdadeiro processo seletivo, um determinado nome para este ou aquele lugar;

2. a seguir, na própria origem semântica da denominação, no significado que revela, de modo transparente ou opaco, e que pode envolver procedências as mais diversas. (DICK,1990a, p.49)

Primeiramente, será apresentado o signo linguístico composto de significante, uma imagem acústica, e significado, um sentido, e cuja relação significante/significado se dá de forma arbitrária $^{37}$, não existindo relação direta entre a palavra e a coisa que ela representa (o referente). Melhor explicando, citar-se-á o triângulo de Ogden e Richards modificado por Ullmann (1973).

\footnotetext{
${ }^{36}$ BENVENISTE, 2006, p.24.

37 A respeito da arbitrariedade do signo linguístico, Benveniste afirma que para aqueles que utilizam a mesma língua materna, a relação significante/significado se torna uma necessidade (1995).
} 


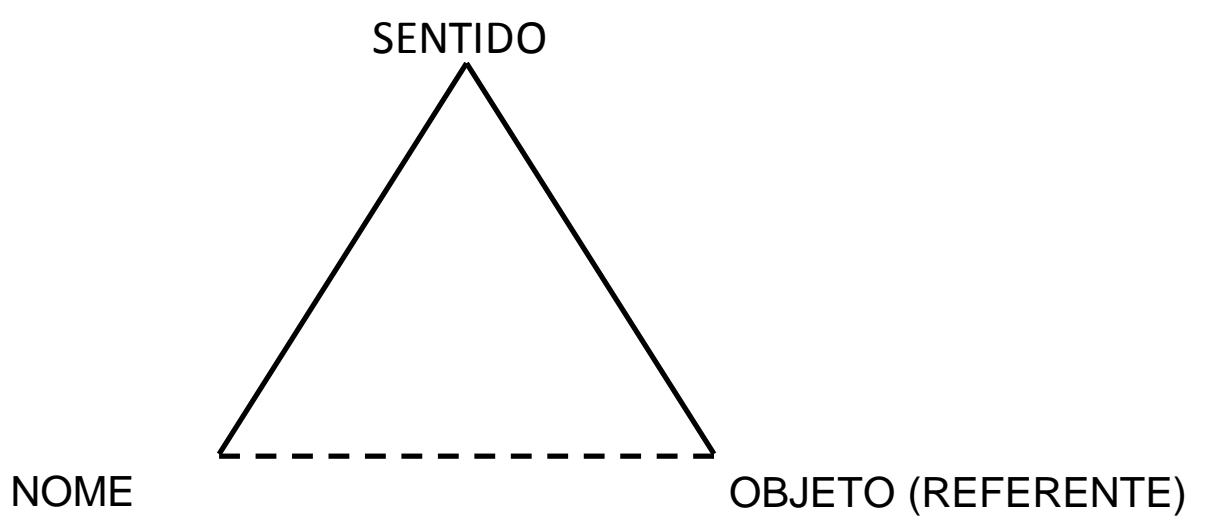

Ullmann (1973, p.116) chama de nome:

a combinação de elementos fonéticos e de sentido à informação que se comunica ao ouvinte. O objeto, com o qual se relaciona o nome, não se liga diretamente a este (como se indica pela linha pontilhada), mas se relaciona através do sentido. O significado de uma palavra será a relação recíproca que existe entre o som e o sentido.

É necessário que o topônimo seja analisado como nome próprio:

a diferença essencial entre os substantivos comuns e os nomes próprios reside na sua função: os primeiros são unidades significativas; os segundos, simples marcas de identificação (ULLMANN, 1973., p.160).

Diferente de outros signos linguísticos, como nome próprio, poder-se-ia dizer que o topônimo é um signo motivado ao partir-se do princípio de que a nomeação não é arbitrária, mas uma escolha. Entretanto, deve-se considerar que raramente se cria novas palavras para dar nome às coisas. Até pelo princípio de economia da língua se faz natural, mesmo ao denominar-se um novo objeto, ou "um novo lugar", até então inexistente, aproveitar-se-á palavras que são parte do universo lexical, pinçadas do sistema e inseridas na norma linguística como vocábulos. 
Los términos son el conjunto de signo lingüísticos que constituyen un subconjunto dentro del componente léxico de la gramática del hablante (CABRÉ, 1995).

Logo, pode-se dizer que a motivação está no denominador e não no sistema linguístico. Segundo afirma Dick (1990a), a "compreensão da existência de um vínculo estreito entre o objeto denominado e seu denominador é que remeterá a toponímia taxionômica ao estudo das motivações da nomenclatura geográfica".

Desse modo, poderia ser dito que a motivação na constituição do topônimo não altera a propriedade de arbitrariedade do signo linguístico, pois o ato de nomear pressupõe apenas uma restrição semântico-sintática de semas lexicais e gramaticais de um lexema (sistema), transformando-o em um vocábulo (norma). O que normalmente acontece com esse vocábulo é que ele adquire uma nova semantização ou ressemantização, recebendo acréscimo da combinatória dos semas contextuais de um campo de conhecimento, levando em consideração as variações diatópicas, diacrônicas, diastráticas e diafásicas.

Portanto, a motivação toponímica se efetivaria, realmente, em nível de palavra ocorrência, na qual o vocábulo seria ressemantizado, levando em conta um contexto geográfico, histórico, étnico, ideológico e, até mesmo, econômico e social, dentro de um percurso semiótico.

Barbosa (1995) diz:

a palavra ocorrência sofre ainda maior restrição (significação específica do texto), mas, ao mesmo tempo, recebe acréscimo da combinatória dos semas contextuais, no percurso sintagmático (epissemema). 
No processo de ressemantização, em nível de discurso manifestado ou palavra ocorrência, a denominação ou ato de nomear passa a ter valor monossemêmico, pois àquela expressão corresponde um só semema que nada mais é que o lugar que ela denomina. Neste momento, seria correto afirmar que o triângulo de Ogden e Richards se fecharia. A linha, antes pontilhada, poderia ser pensada, agora, como uma linha contínua, pois o nome de lugar se ligaria diretamente ao referente que é o próprio lugar.

\title{
SENTIDO
}

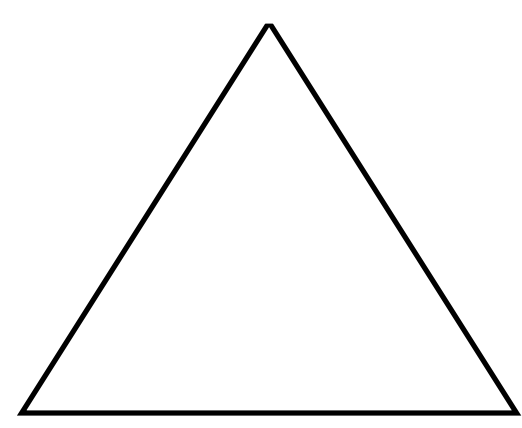

NOME

OBJETO (REFERENTE)

\begin{abstract}
E como diz Dick ${ }^{38}$ :
acidente e nome de lugar, indivíduo e nome pessoal, configuram sempre, uma unidade inseparável, tornandose difícil, por vezes, recuperar as distâncias entre a expressão e o objeto representado.
\end{abstract}

Nesse caso, não existiria um sentido comum que, segundo Hjelmslev (2006, p. 57), dependendo da língua, pode ser moldado diferentemente em expressão e conteúdo.

Pode-se, então, afirmar que a motivação do signo toponímico está no denominador e não no sistema da língua, sendo

${ }^{38}$ DICK ,1999, p.121. 
essa motivação um dos principais objetos dos estudos onomásticos, isto é, a "intencionalidade que anima o denominador".

Ao analisar-se os topônimos como palavra ocorrência dentro do universo da Onomástica, seguiu-se o processo semasiológico, aquele que parte do específico para o geral, "a abordagem que visa, a partir dos signos mínimos (ou dos lexemas), à descrição da significação"39. No plano semiótico, partindo da análise das figuras para a análise das categorias fundamentais, ou da praxis ao logos.

E, novamente, Dick (1990a, p.209) vem esclarecer: "Tomando-se por base o topônimo concretamente manifestado, procedeu-se ao estudo etimológico das formas linguísticas".

\subsection{Aspectos denotativos do signo toponímico, o modelo Dick}

O segundo tema da presente análise leva em consideração os aspectos semânticos do vocábulo toponímico, a origem semântica da denominação.

Eis que é necessário retornar ao triângulo de Ogden e Richards. Nesta explanação, concordou-se que o topônimo, como nome próprio, em sua função dêitica, liga-se diretamente ao referente, que é o próprio lugar. A partir desse pressuposto, tentarse-á entender o signo toponímico em seu aspecto denotativo e estrutural, como indicativo de lugar, e em seu aspecto conotativo, quando estabelece relações semióticas com o homem, o tempo e o espaço. Neste caso, poder-se-ia dizer que existe uma relação metafórica, ou metonímica, entre o nome e o lugar, associados por semelhança ou contiguidade.

Como nome próprio indicativo de lugar, o signo toponímico em seu aspecto estrutural e denotativo está estreitamente ligado ao acidente geográfico que indica. Essa nomenclatura onomástica,

${ }^{39}$ GREIMAS \& COURTÉS, 1979, p.402. 
segundo Dick (1990a), é constituída de um termo ou elemento genérico, relativo à entidade geográfica que receberá a nomeação, e outro, o elemento ou termo específico, ou topônimo propriamente dito, que particularizará a noção espacial, identificando-a e singularizando-a dentre outras semelhantes.

Como componentes do sintagma toponímico, os vocábulos podem se apresentar de forma justaposta (rio Claro), ou de forma aglutinada (Mogi, mboy (cobra) + gy (rio) = "rio das cobras"), de acordo com a língua que os inscreve.

Quando aglutinados, os dois elementos aparecem indissoluvelmente unidos, acidente geográfico e topônimo, não sendo mais possível divisar um do outro, principalmente se a língua usada já extinguiu de seu uso o vocábulo em questão. Nesses casos, faz-se necessário incluir um "novo" termo genérico, indicativo do acidente geográfico, para complementar a ideia daquele que foi absorvido no interior do designativo. No topônimo Apiaí (Apiaí $+y=$ rio dos meninos), como se pode perceber, 0 termo genérico ( $y=$ rio) está embutido no termo específico, mas não é mais reconhecido como tal, fazendo-se necessário o uso do correspondente em português, "rio" Apiaí.

Há o caso em que o termo genérico engloba as duas categorias: a de determinado e a de determinante. Para Dick (1990a, p.11), tal fato ocorre devido a vários motivos: o acidente pode ser único na região,

tornando desnecessárias as complementações referenciais ou, ele é tão significativo para a comunidade que, "nomeá-lo" ou acrescentar-lhe outras características, é desvirtuá-lo ou retirar-lhe o caráter de plenitude enfática que se empresta ao nome comum, tornado próprio, então, na fala do povo. 
Algumas vezes, o termo genérico vem acompanhado de um qualificativo que não altera sua função de determinado e determinante, apenas o explicita, tornando-o mais descritivo, como exemplo tem-se o topônimo rio Grande.

Os topônimos podem ser classificados por sua composição morfológica como simples, compostos ou híbridos. O termo específico é o que determina esta classificação, partindo do princípio apresentado por Dick (1990a) de que esse é o termo que determinará a motivação dos designativos de lugar.

O topônimo ou elemento específico simples é aquele constituído por um só formador, predominantemente um substantivo ou adjetivo, podendo apresentar-se acompanhado de sufixação (diminutivo, aumentativo, ou de outras procedências linguísticas). Tomou-se como exemplo topônimos de corpus da presente pesquisa: Araponga (serra e bairro), Iporanga ( cidade e ribeirão), Palmital (rio).

Um topônimo ou elemento específico é caracterizado como composto quando apresenta mais de um elemento formador. Há, para exemplificar, Onça Parda (serra), Monte Negro (serra), André Lopes (bairro, rio). Em língua indígena tupi predominam os compostos como: -mirim (pequeno), -guaçu (grande) e suas variantes, -uçu, -açu; -tyba (sufixo coletivo) e as variantes deste, tuba, -nduba, -nduva, -ndiba; encontrou-se: Apiaí Guaçú (rio), Gurutuba (serra), Taquari Mirim (rio).

Os híbridos são aqueles em que o elemento específico é formado por elementos linguísticos de diferentes procedências. No Brasil, o que predomina é a composição português + indígena ou indígena + português. São José do Guapiara (rio), Betarizinho (rio e cachoeira), Alambari de Baixo (caverna) apresentam essa característica. O primeiro é formado por um vocábulo de origem 
portuguesa (São José), seguido de um termo em língua indígena tupi (Guapiara); no segundo, ao vocábulo indígena Betari, segue-se o sufixo diminutivo português, -inho.

De acordo com Dick (1990a), os topônimos podem ser agrupados em duas vertentes, os de natureza física ou natural, (A.F.), e os de natureza antropocultural (A.H.) que definirão as taxionomias toponímicas. As taxes são motivações que privilegiam, em uma análise sincrônica, os aspectos denotativos dos denominativos de lugar. "A configuração do acidente geográfico nomeado representaria uma projeção aproximativa do real, tornando clara a natureza semântica (ou transparência) de seu significado" (DICK 1990a). Rio Claro, ribeirão Grande, por exemplo, fazem referência às características próprias do acidente nomeado. Nesse aspecto, Dick sugere que haveria uma aproximação do topônimo aos conceitos de ícone e símbolo propostos por Pierce. Acredita-se que, como signo indicativo de lugar, em sua função dêitica, os topônimos podem também ser entendidos como indicadores ou índices.

Segundo Pierce, "um signo é um ícone, um indicador ou um símbolo". O ícone é compreendido como o signo que:

(...) opera, antes de tudo pela semelhança de fato entre seu significante e seu significado. (...) $\mathrm{O}$ símbolo, o signo que opera por contiguidade instituída, apreendida entre significante e significado. Esta conexão "consiste no fato de que constitui uma regra" e não depende da presença ou da ausência de qualquer similitude ou contiguidade de fato. O índice (ou indicador) opera, antes de tudo, pela contiguidade de fato, vivida, entre seu significante e seu significado ${ }^{40}$.

${ }^{40}$ PIERCE, Charles apud Jakobson, Roman. Linguística e Comunicação, 1995, p.101. 
A iconicidade no signo toponímico está implícita (não há semelhança de fato) na existência de um vínculo entre ele e seu referente; está presente na descrição precisa dos aspectos físicos e antropoculturais, isto é, quando o designativo de lugar descreve com precisão características físicas ou culturais do lugar nomeado, tais como cor, forma, tamanho, constituição natural, conforme explicitado com rio Claro, ribeirão Grande, e os denominativos de origem indígena. Entretanto, nestes, não se conseguiu mais perceber esta relação de similitude, por ser desconhecida a língua de partida, o que ocorre em rio Paranapanema (Paranã - pãnema, o caudal impraticável, de difícil de navegação).

Em sua função dêitica, como nome próprio, o topônimo é sempre um indicador de lugar.

Os indicadores podem distinguir-se de outros signos ou representações, graças a três traços característicos: primeiro, eles não têm semelhança significativa com seus objetos; segundo, eles se referem a individuais, a unidades singulares, a coleções singulares, a coleções singulares de unidades ou a contínuos singulares; terceiro, dirigem atenção para seus objetos por compulsão cega. Contudo, seria difícil se não impossível apontar um indicador absolutamente puro ou um signo absolutamente despido de qualidade indicadora (PIERCE, 1975, p. 133).

Como símbolo, o signo toponímico:

se relaciona a seu objeto pela convenção de que será como tal entendido, ou por instinto natural, ou por ato intelectual que o toma como representativo de seu objeto, sem que se dê, necessariamente, qualquer ação que poderia estabelecer uma conexão factual entre o signo e o objeto (PIERCE, 1975, p. 134). 
Pode-se perceber a complexidade dos estudos dos signos toponímicos. Nesta abordagem, quanto a seu aspecto denotativo de representação de lugar, buscou-se observar se os topônimos são predominantemente símbolos, ícones ou indicadores. Concluiuse que os topônimos, como signos linguísticos, são prioritariamente símbolos ("toda palavra é um símbolo"41) que podem comportar um ícone e/ou um índice a ele incorporado, conforme Pierce.

Um estudo etimológico do vocábulo toponímico, principalmente os de língua indígena já extinta (por exemplo, o tupi antigo), é de grande importância para a reconstrução de significações não mais transparentes. Em virtude da opacidade que esses topônimos adquiriram, a análise etimológica reconstrói, por meio da correta interpretação, os fundamentos para uma melhor compreensão e identificação dos lugares. Nesse aspecto, é indiscutível a contribuição que esses estudos trazem para o conhecimento de estilos de vida diferentes, dos quais, os vestígios só são perceptíveis nos nomes geográficos.

Segundo Dick (1990a, p.22):

não é de se estranhar, portanto, a existência de uma relação analógica entre o topônimo e algum fato do cotidiano indígena. (...) as antigas expressões onomásticas [são] reveladoras (...) não apenas dos característicos típicos da região, firmados na nomenclatura descritiva ou associativa, como também [o são] das línguas porventura faladas no local, em épocas anteriores, e as espécies animais e vegetais fossilizadas. [...] Mas esta função cristalizadora da significância só se torna possível porque o nome de lugar exerce, concomitantemente, o papel de uma verdadeira crônica, em que os fatos atuais se projetam no futuro, através da inscrição onomástica, possibilitando dessa forma, sua análise posterior.

${ }^{41}$ PIERCE, Charles apud Jakobson, Roman. Linguística e Comunicação, 1995. 
O topônimo deve ser tratado como um verdadeiro "artefato linguístico" ${ }^{\text {42 }}$ quando conserva formas de falares extintos; em nosso corpus de análise, foram encontrados denominativos geográficos que remontam ao início da colonização, ou até mesmo a antes da chegada dos europeus no século XVI. Esses nomes de lugares configuram uma nomenclatura preciosa para as futuras gerações, pois, cada vez mais, aspectos importantes dessas antigas sociedades desaparecerão e, somente pelo estudo desses designativos, poder-se-á resgatar esse universo étnico que foi fundamental na constituição do ethos brasileiro.

Para Lyons (1991, p.216, p.219):

Names, as they are employed in every languagebehavior, have two characteristic functions: referential and vocative [...] [and names] may have reference, but not sense, and that they cannot be used predicatively purely as names

Considera-se que o nome próprio de lugar, tanto quanto o nome próprio de pessoas, não tem um sentido comum, excetuando algumas alterações semêmicas que ocorrem em alguns vocábulos. Essas palavras não fazem parte do universo da lexicografia, ou melhor, normalmente, os nomes próprios não são dicionarizados. Porém, diferente dos antropônimos, os topônimos, ao estabelecerem relações semióticas entre o lugar e o homem que ocupa esse lugar, merecem um estudo mais aprofundado. Essas relações serão tratadas, levando-se em conta os aspectos conotativos dos denominativos de lugar.

\footnotetext{
${ }^{42}$ A concepção do termo artefato aqui empregada é cultural e arqueológica, isto é, toma-se o termo como qualquer objeto feito ou modificado por um humano.
} 


\subsection{Aspectos conotativos do signo toponímico}

Como mencionado anteriormente, procurar-se-á explicitar o caráter metafórico e metonímico dos nomes geográficos, pois se entende que, por meio desta compreensão, a simbiose existente entre o homem e o território ocupado pelo homem se torna mais clara. Para Bally ${ }^{43}$ :

a maior imperfeição do nosso espírito consiste na incapacidade de abstrair em absoluto, isto é, de isolar um conceito ou conceber uma ideia fora de qualquer contato com a realidade concreta.

O topônimo está naturalmente inserido nesse pressuposto, pois as relações denominador/denominado implicam associações contextuais importantes entre o nome e o referente que não permitem que o designativo de lugar seja "abstraído em absoluto" da realidade concreta.

Para melhor explicitar os aspectos conotativos do signo toponímico, é necessário retomar a afirmação de que nome de lugar e o lugar estabelecem uma unidade inseparável, como verificado no triângulo de Ogden e Richards: a linha, antes pontilhada, ligando nome e referente é para nós uma linha contínua. Partindo dessa perspectiva, pode-se considerar o nome de lugar, ou mesmo, o nome de pessoa como uma entidade "mítica", imbuído de subjetividade, na medida em que é visto como parte integrante da pessoa ou do lugar que nomeia.

Para Cassirer (2006, p.68):

a identidade essencial entre a palavra e o que ela designa torna-se ainda mais evidente se, em lugar de considerar tal conexão do ponto de vista objetivo, a tomamos de um ângulo subjetivo. Pois também o eu do homem, sua mesmidade $\mathrm{e}$

\footnotetext{
${ }^{43}$ BALLY, Charles apud CRESSOT, Marcel. O Estilo e as suas técnicas. Lisboa: 1980. p. 64.
} 
personalidade, estão indissoluvelmente unidos com seu nome, para o pensamento mítico. $O$ nome não é nunca um mero símbolo, sendo parte da personalidade de seu portador; é uma propriedade que deve ser resguardada com o maior cuidado e cujo uso exclusivo deve ser ciosamente reservado.

Sob este aspecto, as apreensões linguística e mítica dos denominativos tendem à condensação, à concentração e à caracterização isolada (redução sêmica ${ }^{44}$ ), diferente do pensar teórico e discursivo, cuja percepção individual é referida à totalidade do ser e do acontecer, a palavra se interpõe entre os diferentes conteúdos e essa interposição é que lhe confere a liberdade e agilidade que lhe permite mover-se entre um conteúdo e outro, e conectá-los entre si (ampliação sêmica).

Primeiramente, procurar-se-á estabelecer fundamentos dos processos metafóricos e metonímicos a fim de clarificar as considerações apresentadas.

A metáfora estaria instalada no eixo da substituição e seleção, enquanto que a metonímia se posicionaria no eixo das combinações e contextura, de acordo com Head. ${ }^{45}$ É a relação externa da contiguidade que une os constituintes de um contexto e a relação interna da similaridade que serve de base para a substituição.

Um tema pode levar a outro, quer por similaridade, quer por contiguidade. $O$ mais acertado seria, provavelmente, falar de processo metafórico, no primeiro caso, e de processo metonímico no segundo, uma vez que eles encontram sua expressão mais condensada na metáfora e na metonímia, respectivamente. (JAKOBSON, 1995, p. 55)

\footnotetext{
${ }^{44}$ BARBOSA, M. A. Léxico, produção e criatividade. São Paulo, Plêiade, 1996.

${ }^{45}$ HEAD, H. apud Jakobson, R. Linguística e Comunicação, 1995.
} 
Resumindo, afirma-se aqui que a metáfora e a metonímia são a vinculação de um significante a um significado secundário, associado, por semelhança ou contiguidade, ao significado primário.

É necessário compreender de forma individualizada os processos metafóricos e metonímicos dos denominativos geográficos no qual o conteúdo fique reduzido a um só ponto, não imergindo de modo algum "na" palavra, mas, sim, dela emergindo.

Aquilo que alguma vez se fixou em uma palavra ou nome, daí por diante nunca mais aparecerá apenas como uma realidade, mas como a realidade. Desaparece a tensão entre o mero "signo" e o "designado"; e em lugar de uma expressão mais ou menos adequada, apresentase uma relação de identidade, de completa coincidência entre a "imagem" e a "coisa", entre o nome e o objeto. (CASSIRER, 2006, p.76).

A identidade significativa entre nome de lugar e lugar é mais sensível, em especial nos topônimos de origem indígena, cuja força "mítica" motivadora exprime o íntimo convívio do homem indígena com a natureza, "visto que toda a Natureza ressoa, nada mais natural, para o homem sensível, que ela viva, fale, atue" (CASSIRER, 2006, p.102).

Parte do corpus de análise pressupõe-se que remeta a um Brasil anterior à chegada dos europeus. Topônimos como Ivaporunduva, Iporanga, Apiaí e Xiririca foram encontrados em documentação do século XVI. São descrições autênticas dos habitantes naturais daquela região e são esses denominativos geográficos que, em sua configuração conotativa, estabelecem relações metonímicas e/ou metafóricas: Taquari, Palmital, Alambari, Iporanga, Paranapanema. 
Os rios são naturalmente entidades mitológicas desde os primórdios das civilizações, pois, sem água não há vida. Aqui, os nomes de rios têm importância estratégica, pois são eles que, de certa forma, conduzem o relacionamento do homem com o território ocupado e, como grande parte desses nomes hidrográficos é de origem indígena, procedentes dos primórdios da colonização, entende-se serem eles descrições das relações do homem com o lugar, linguisticamente configuradas em processos metafóricos ou metonímicos.

Se o topônimo for entendido como homônimo de outro vocábulo da língua, a relação entre similaridade e contiguidade se torna ainda mais complexa, pois a cada escolha haveria uma transposição por seleção e/ou por combinação de uma palavra levada de um conceito a outro no ato denominativo. Seria a criação de um novo conceito, por meio de um velho nome. Isso quer dizer que as escolhas de denominativos de lugar levam em consideração características, ou melhor, semas do vocábulo escolhido que se quer conduzir ao novo, ocorrendo, em tal caso, uma transposição de conteúdos.

Quando se faz a eleição por designativos de santos ou mesmo de Nossa Senhora para determinada localidade, por exemplo, aí estaria sugerida a busca por "proteção divina" ou "poderes mágicos", ou mesmo "graças" para o lugar "abençoado" com esse nome. Já, quando topônimos como Salesópolis ou Suzano são encontrados, percebe-se que tais escolhas pressupõem relações significativas com os antropônimos dos quais se originaram, daí entender-se que haveria transferência de sentido ou tropos. 
Novamente, depara-se com questões complexas relacionadas ao estudo dos signos toponímicos, que justifica, dessa forma, a pesquisa onomástica.

São as taxionomias toponímicas definidas por Dick que constroem a ponte semântica entre o lugar e o nome do lugar. Apesar de aquelas privilegiarem os aspectos denotativos contidos no termo específico do sintagma toponímico, a relação entre o denominador e o nome é sempre uma relação subjetiva, pois pressupõe a contextualização e a mediação entre o símbolo e o que se quer representar, convertendo o que se quer representar em parte do mundo do designador ou designadores. São essas considerações que encaminham para a compreensão dos aspectos culturais presentes no signo toponímico.

Como marcador de lugar, o topônimo é o símbolo das relações semióticas entre o espaço físico e as pessoas que ocupam esse espaço, entre o território, considerado como o espaço modificado pelo homem, e o homem, que ocupa e modifica esse espaço. Portanto, estudar toponímia é estudar as relações do homem com seu meio pelo ato de nomear, é estudar a língua e as relações do homem com essa língua. Toponímia, sob tal aspecto, é o estudo das relações do homem com o tempo, o espaço, o meio social, (chronos, topoi e stratum).

Sendo a língua o instrumento principal deste estudo, é conveniente partir-se da compreensão de língua como visão de mundo, recorte cultural de uma comunidade falante, Sapir ${ }^{46}$ afirma que "os universos em que vivem as diferentes sociedades são universos distintos, e não o mesmo universo com diferentes rótulos".

${ }^{46}$ Sapir, E. A Linguagem, 1980. 
O estudo da toponímia pressupõe não só o estudo da língua, mas também da população que fala essa língua, do espaço em que vive o falante dessa língua, o tempo em que vive ou viveu este falante, daí a pressuposição de que os estudos toponímicos são mais do que estudos linguísticos, são, também, estudos etnolinguísticos, pois a etnolinguística, inserida nos estudos dos denominativos de lugar, complementa a pesquisa toponímica.

Estudando o homem, o espaço ocupado pelo homem e o tempo em que vive ou viveu esse homem, a toponímia confronta valores que podem ser questionados ou analisados em um contexto ambiental e sociocultural. Para Lyons (1979, p.475):

a língua de uma determinada sociedade é uma parte integral de sua cultura, as distinções lexicais de cada língua tenderão a refletir traços culturalmente importantes de objetos, instituições e atividades em que a língua opera.

Hjelmslev (2006, p.56) afirma que "o sentido é ordenado, articulado, formado de modo diferente segundo as diferentes línguas". Ele apresenta um mesmo domínio de substância semântica, recortado em dinamarquês, alemão e francês.

\begin{tabular}{l|l|l}
\multirow{4}{*}{ troe } & Baum & arbre (árvore) \\
\cline { 2 - 3 } skov & Hols & bois (bosque) \\
\cline { 2 - 2 } & Wald & forêt (floresta)
\end{tabular}

Pode-se verificar que o sentido nessas unidades lexicais deve ser analisado de um modo particular nas diferentes línguas. Assim também, inseridos neste campo de pesquisa, a unidade 
lexical paraná, em tupi/guarani, em relação às unidades lexicais, "rio" e "mar", em português, pertencentes à mesma zona de sentido, devem ser analisadas distintamente.

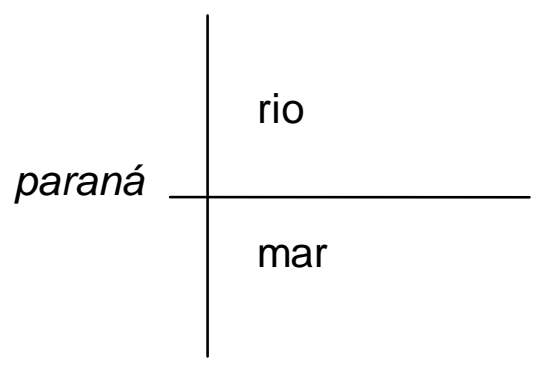

Acerca desse exemplo, vale observar que Padre Lemos Barbosa, em seus estudos, afirma que "os índios de língua tupi não faziam distinção categórica entre 'rio' e 'mar'. Quiçá nem mesmo os guaranis". 47

Portanto, ao analisar-se os topônimos, sua estrutura, sua etimologia, as transformações que sofreram no chronus, no topoi e na phasis, deve-se tirar o sentido possível dessa lexia ou sintagma lexical, levando em conta sua estrutura lexical e sua língua de origem.

Além das transformações semântico-sintáticas por que passou o vocábulo, é importante, ao se fazer uma análise do léxico toponímico, considerar-se os aspectos culturais, a formação étnica, aspectos econômicos, políticos e sociais da comunidade falante e suas relações simbólicas com a língua.

Trabalhou-se em nossa pesquisa de Mestrado com o topônimo Jundiapeba que, em um primeiro momento, foi considerado uma unidade lexical de origem tupi, mas após pesquisa, descobrimos que se tratava da combinação de dois denominativos de rios importantes da região, Jundiaí e Taiaçupeba.

47 LEMOS BARBOSA, Padre Antonio. O vocabulário na língua brasílica. Rio de Janeiro: Ministério da Educação e Saúde, 1948, p. 21. 
Pouco confortável com o estigma do antigo nome do lugar, Santo Ângelo, que estava fortemente vinculado ao leprosário de mesmo nome localizado naquela região, a comunidade decidiu que uma mudança do designativo desvincularia o lugar com o estigma da doença. Nesse caso, o sentido ${ }^{48}$ desse topônimo não deve ser pesquisado no vocábulo, mas, sim, nas relações que a população mantém com o lugar. Portanto, o topônimo, para ter sentido, deve estar inserido em uma explicação baseada na compreensão do tempo, do espaço, das instituições sociais, enfim, de todo um contexto extralinguístico. Podemos dizer que a função semiótica no signo toponímico não se dá somente entre a forma do conteúdo e a forma da expressão(HJELMSLEV, 2006, p. 62), mas também em relação ao referente.

O topônimo não é algo estranho ou alheio ao contexto histórico-político da comunidade. Sua carga significativa guarda estreita ligação com o solo, o clima, a vegetação abundante ou pobre e as próprias feições culturais de uma região em suas diversas manifestações de vida (DICK, 1990a).

Wilhelm Von Humboldt, referindo-se à linguagem, diz:

O homem vive com seus objetos fundamental e até exclusivamente, tal como a linguagem Ihos apresenta, pois nele o sentir e o atuar depende de suas representações. Pelo mesmo ato, mediante o qual o homem extrai de si a trama da linguagem, também vai se entrelaçando nela e cada linguagem traça um círculo mágico ao redor do povo a que pertence, círculo do qual não existe escapatória possível, a não ser que se pule para outro ${ }^{49}$.

\footnotetext{
${ }^{48} \mathrm{O}$ sentido do topônimo não é seu significado, mas, sim, as relações existentes entre o denominador e o objeto denominado.

${ }^{49}$ HUMBOLDT, W. Von. apud Cassirer, E. Linguagem e Mito, 2006, p. 23
} 
À guisa de conclusão, afirma-se que, como a língua reflete a comunidade falante, a comunidade está inserida nesse universo linguístico sendo, por sua vez, um retrato dessa língua. Estudar língua, portanto, pressupõe estudar o "entrelaçamento" homem/língua, língua/homem.

\subsection{0 conceptus do nome próprio de lugar em uma abordagem metafórica e metonímica}

Um dos objetivos desse trabalho é o de justificar os aspectos conceituais do signo toponímico, para isso deve-se salientar que o nome de lugar está intimamente ligado ao conceito de espacialidade, tendo em vista que o topônimo "significa", ou melhor, estrutura e sistematiza; dá significado à experiência do homem em relação ao espaço denominado. Esta análise baseia-se, principalmente, no conceito de espaço, no sentido de que o espaço nada mais é que a localização do homem em seu ambiente, aspectos orientacionais e dêiticos dos denominativos de lugar pautaram a análise. O conceito de espaço como recipiente desenvolvido por Lakoff e Johnson (1980) fundamentou o argumento de que nomes de lugar são também lexias constituídas por um conceptus metafórico/metonímico.

Para Norberg-Schulz (1980) o espaço só é lugar ao se tornar significativo para o homem. O lugar é, talvez, o principal aspecto na formação da identidade do homem. Somente quando o homem compreende o espaço em que vive ele é capaz de participar criativamente e contribuir com a história. A abordagem de NorbergSchulz, também é parte da base teórica aqui apresentada para justificar os aspectos conceituais do signo toponímico. 
De acordo com Fillmore ${ }^{50}$, há duas subcategorias de dêixis, uma das subcategorias é a dêixis de lugar a qual se relaciona com a percepção do falante em relação à posição que ocupa no espaço tridimensional. A segunda subcategoria é a dêixis de tempo relacionada à posição do ato de fala no tempo ou, o tempo do ato denominativo (o quando), relacionando o tema ao universo de dessa pesquisa. $\mathrm{Na}$ análise toponímica aqui apresentada, considerou-se os nomes de lugar em sua relação espacial, já que naturalmente o topônimo define um lugar. As relações temporais são analisadas do ponto de vista dos aspectos identitários, relacionais e históricos do lugar, entendendo que espaço pressupõe tempo, tudo o que acontece em um determinado local está fatalmente condicionado à temporalidade daquele evento.

Fillmore (1997) também explicita a diferença entre a concepção "dêitico" e "não dêitico" em que a primeira pressupõe o ponto de vista do emissor; já no segundo caso, o ponto de vista do emissor é irrelevante. Quanto ao ato de denominar, levou-se em conta que se trata sempre de relações dêiticas cujo ponto de vista do denominador ou denominadores deve ser relevante, e esta é a razão de considerar-se, aqui, o topônimo como um signo motivado. No contexto em que o ponto de vista do emissor seria irrelevante, deve-se levar em conta a comunidade que ocupa o espaço denominado e se apropria do denominativo já existente incorporando-o como seu, tornando-se parte do nome ao mesmo tempo em que o nome torna-se parte dessa comunidade, identificando-a (os gentílicos). Nesse caso, não há um ponto referencial e sim um todo comum. Lugar e comunidade se confundem.

\footnotetext{
${ }^{50}$ Fillmore, C. Lectures on Deixis, 1997.
} 
$O$ ato denominativo nada mais é que um ato de tomada de posse do espaço convertendo-o em lugar ou território (entendendose território como a apropriação humana de um conjunto natural pré-existente).

Tuan $^{51}$ afirma que o significado de espaço se funde ao de lugar, uma vez que as duas categorias não podem ser compreendidas uma sem a outra. $\mathrm{O}$ que começa com um espaço indiferenciado, transforma-se em lugar à medida que 0 conhecemos melhor e o dotamos de valor. "O espaço transformase em lugar à medida que adquire definição e significado" (Tuan, 1983, p.151).

Para Norberg-Schulz (1971), o interesse do homem pelo espaço tem raízes existenciais, deriva da necessidade de compreender relações vitais em seu meio ambiente e trazer significado e ordenação em um mundo de eventos (acontecimentos) e ações. Basicamente o homem se orienta pelos objetos, a maioria das ações do homem compreende um aspecto espacial, no sentido de que os objetos de orientação são distribuídos em concordância com tais relações como: dentro-fora; longe-perto; separado-unido; contínuo-descontínuo, entendendo o espaço/lugar como recipiente com uma superfície limitada.

Esse ponto de vista coincide com a abordagem de Lakoff e Johnson ao descreverem o espaço em um conceptus metafórico e/ou metonímico em que as extensões de terra e o campo visual podem ser concebidos como substâncias, objetos e recipientes.

...gerou as famílias dele aqui dentro do bairro de São Pedro. (relato de Edu Nolasco de França a sobre a chegada de seu bisavô à região).

${ }^{51}$ Tuan, Yi-Fu . Espaço e Lugar, (1983). 
Ele respondeu que para quem é de fora aqui é o paraíso.... (Antonio Ribeiro, morador da comunidade de Praia Grande).

A Inveja era do amo Diogo de Moura (relato de Renato Gomes do Nascimento, apud Cadernos do ITESP 2, 2000,p. 89)

Enquanto que o espaço físico dos animais é uma função dos instintos, o homem tem de apreender a orientação necessária, de modo a poder atuar no ambiente. Para ser capaz de cumprir suas intenções, ele deve perceber as relações espaciais e unificá-las em um conceptus espacial. Do ponto de vista deste trabalho, o topônimo poderia ser a síntese desse conceptus espacial, pois pressupõe a apreensão do espaço tornando-o lugar.

Desde as primeiras civilizações são encontrados termos que expressam e comunicam relações espaciais tais como: acimaabaixo; frente-atrás, esquerda-direita, que não são abstratos, eles referencializam diretamente o homem em seu meio ambiente e expressam a sua posição no mundo. Nesse contexto, certas línguas africanas usam a mesma expressão para olho e "em frente de". O conceito de espaço dos antigos egípcios pela geografia particular de seu país e de sua língua introduziu os termos "rio acima" e "rio abaixo" (Norberg-Schulz, 1971, p.68).

Também na região de Iporanga, em razão da íntima convivência com o rio Ribeira e o ribeirão Iporanga, notou-se que a concepção do espaço está intimamente ligada ao fluxo dos rios, em especial para os moradores mais antigos, que tinham nos rios não só sua principal fonte de sobrevivência, mas o caminho que os mantinha interligados com toda a região. "Dona Dita, moradora do bairro da Serra, conta que nasceu em um local um pouco mais distante, Ribeira acima, chamado João Surá." (SILVEIRA,2001.p.9) 
Ainda hoje, existe na região comunidades que dependem exclusivamente do rio para se deslocarem. A comunidade de Praia Grande, a sudoeste do Petar, tem o rio como único meio de ligação com as cidades de Iporanga e Eldorado. O barco é o único meio de transporte para saírem do bairro.

O barcu tão tudu descendo p'a Iporanga, p’a levá o pessuau (Benedito Cordeiro, morador do bairro de João Surá, vizinho a Praia Grande). ${ }^{52}$

Esses exemplos deixam claro que o conceito de espaço não foi abstraído da experiência direta das relações com o ambiente. A intuição espacial dos primitivos são orientações concretas as quais referem a objetos e localidade e, portanto tem uma forte cor emocional.

...eu não vejo saída, as saídas que eu vejo são essas, criar novas alternativas em função do meio ambiente! (Jurandir morador do Bairro da Serra- SILVEIRA, 2001, p. 172)

veio daqui do lado do Paraná, entrou trilha e gostou do mato aqui, era tudo fechado, sertão ( Dona Luiza, moradora do bairro da Serra - SILVEIRA, 2001,p.177).

Em certo sentido, todo homem que elege um lugar do seu ambiente para se estabelecer e viver, é um criador do espaço expressivo. Dá significado ao seu ambiente, assimilando-o com determinados propósitos, ao mesmo tempo em que se acomoda às condições que este lhe oferece. O lugar, portanto, é mais do que uma localização geográfica, mais do que um simples espaço, o lugar é a concreta manifestação do habitar humano. Mais do que uma localização abstrata o lugar é uma totalidade composta de

\footnotetext{
${ }^{52}$ Inventário Cultural de Quilombos do Alto do Ribeira- Parte 1. Disponível em https://www.youtube.com/watch?feature=player embedded\&v=dS7kSj3Vzhl, acessado em 04 de julho de 2013.
} 
coisas concretas tendo substância material, forma, textura, cor. Juntas determinam um caráter ambiental que é a essência do $\operatorname{lugar}^{53}$.

A estrada mais que uma porta de entrada representou uma porta de saída (LINO, 1980, p. 32).

O turismo parece ter vindo ocupar com muito mais sucesso e estabilidade, o nicho antes ocupado pela mineração e o corte de palmito (SILVEIRA, 2001, p.179).

...moradores que não possuem consanguíneos ou afins de famílias antigas no bairro é de vinte por cento. Esta diferenciação presente entre os de dentro e os de fora (ELIAS e SCOTSON, 2000, p. 182).

Conceitualizam o espaço (estrada) como um continente e as pessoas são substância. No exemplo seguinte, o turismo é definido como uma entidade, que é a substância do continente lugar.

Norberg-Schulz desenvolve o conceito de espaço existencial o qual compreende as relações básicas entre o homem e seu ambiente. O conceito de espaço existencial é aqui dividido nos termos complementares "espaço" e "carácter", diretamente relacionados com as funções básicas psíquicas de "orientação" e "identificação".

O autor afirma ainda que o Homem habita onde consegue se orientar e identificar-se com o ambiente, ou, simplesmente quando percebe o ambiente com algum significado. Portanto, habitar implica muito mais do que obter um abrigo. Implica que os espaços onde se vive sejam lugares, com verdadeiro sentido de mundo. Um lugar é um espaço com caráter ${ }^{54}$. Desde a antiguidade, o genius

\footnotetext{
${ }^{53}$ Norberg-Schulz, Genius Loci, 1980, p.8

54 De acordo com Norberg-Schulz (1971) o caráter de um lugar é determinado pela identidade própria dos objetos que constituem o Lugar, pelos fenômenos
} 
loci5 ${ }^{55}$, ou o espírito do lugar é reconhecido como a realidade concreta com a qual o homem tem que se defrontar e que é transportado para sua vida cotidiana.

Um lugar é, portanto, um fenômeno qualitativo e total que não pode ser reduzido a nenhuma de suas propriedades como as relações espaciais, sem perder a sua natureza concreta. O lugar é a manifestação do habitar humano. O espaço só se torna lugar no momento em que ele é habitado pelo homem, física ou simbolicamente. O dar nome é o ato de apropriação simbólica do lugar.

(...) man's basic organic needs, such as hunger and thirst, follow rhythmic patterns. Furthermore, man is part of a system of natural rhythms, such as night and day, the change of seasons and his own 'ages'. Piaget says appropriately: "Life is a creator of patterns". In other words, we become what we do. In this sense, life interprets itself as space by taking possession of the environment (NORBERG-SCHULZ, 1971, p.35).

Desse ponto de vista, ao ocupar o espaço e dar nome ao lugar, o homem ao mesmo tempo em que transforma o ambiente se identifica com o lugar, ou melhor, se mescla ao ambiente e passa a ser parte dele. Portanto, a presente abordagem em relação aos aspectos metafórico e metonímico dos nomes de lugar nada mais é que tentar, por meio dos topônimos, compreender esse imbricamento lugar e homem, isto é, o topônimo seria uma metáfora/metonímia conceitual do próprio homem em suas relações com o ambiente, tanto relações físicas, concretas, como relações simbólicas, subjetivas. Nesse sentido, pode-se dizer que os

concretos que condicionam o habitar e a identificação do Homem com um ambiente espacial determinado.

${ }^{55} \mathrm{O}$ autor retoma o conceito de genius loci desenvolvido pelos antigos romanos em que cada lugar era regido por um deus ou o espírito do lugar (1980). 
conceitos metafóricos e metonímicos relativos ao espaço ocupado são, portanto, resultado do espaço vivenciado e conceitualizado pelo homem e demarcam aspectos culturais, sociais e históricos.

A compreensão emerge da interação e da negociação constante com 0 ambiente e com as outras pessoas. Essa interação com o ambiente envolve uma troca mútua, não podemos atuar no ambiente sem alterá-lo ou ser alterado por ele (LAKOFF e JOHNSON 1980, p. 230) ${ }^{56}$.

Norberg-Schulz (1980) complementa, propondo que a palavra habitar indica uma relação total homem-lugar. Quando o homem habita, ele é simultaneamente situado no espaço e exposto a certo caráter ambiental.

Partindo da relação homem-lugar e tendo em vista que as representações simbólicas estão incorporadas a vivencia do homem ao seu espaço, propôs-se analisar os denominativos do entorno do Petar sob a perspectiva dos processos metafóricos e metonímicos.

Para Lakoff e Johnson (1980), a metáfora está impregnada à vida cotidiana, não só na linguagem mas também no pensamento e na ação. O sistema conceitual ordinário, em termos do qual se pensa e atua, é fundamentalmente de natureza metafórica.

Os autores afirmam ainda que os conceitos que regem 0 pensamento não são simplesmente problema do intelecto, eles também regem o funcionamento cotidiano, até os detalhes mais mundanos. Os conceitos estruturam o que se percebe, como se move no mundo, a maneira como se relacionar com outras pessoas; o sistema conceitual, portanto, desempenha um papel central na definição das realidades diárias.

\footnotetext{
${ }^{56}$ LAKOFF, G.; JOHNSON, M. Metaphors We Live By, The University of Chicago Press, Chicago and London, 1980.
} 
Do mesmo modo, Lakoff e Johnson dizem que se estamos certos ao sugerir que nosso sistema conceitual é em grande medida metafórico, então, a maneira como se pensa, o que se experimenta e o que se faz cada dia também é, em grande medida, questão de metáfora. Como a comunicação se baseia no mesmo sistema conceitual que se emprega para pensar e atuar, a linguagem é uma importante fonte de evidência de como é esse sistema.

The essence of metaphor is understanding and experiencing one kind of thing in terms of another (LAKOFF e JOHNSON, 1980, p.5).

A metáfora não é somente uma questão de linguagem, quer dizer, de meras palavras, ao contrário, os processos do pensamento são em grande medida metafóricos. Nesse sentido, o sistema conceitual humano está estruturado e se define metaforicamente. As metáforas como expressões linguísticas são possíveis precisamente porque há metáforas no sistema conceitual das pessoas. Metáforas como "argumento é uma guerra", "o tempo é dinheiro" etc., devem ser entendidas como um conceptus metafórico (LAKOFF e JOHNSON, 1980, p. 8).

$O$ topônimo define um recorte espacial. Como afirmado acima, o topônimo representa um lugar, melhor ainda, o topônimo é o lugar, pois o espaço habitado física ou simbolicamente se torna um lugar e, portanto, o ato de dar nomes pressupõe a apropriação do espaço pelo homem, mesmo que seja uma apropriação simbólica. Buscou-se compreender conceitualmente o nome de lugar, tendo por base seus aspectos metafóricos e metonímicos entendendo que a metáfora e a metonímia mantêm relações isomórficas com o lugar denominado. 
Do ponto de vista de Hofstadter ${ }^{57}$, a palavra isomorfismo se aplica quando duas estruturas complexas podem ser mapeadas uma sobre a outra, de tal forma que para cada parte de uma estrutura haja uma parte correspondente na outra estrutura, no qual "correspondente" significa que as duas partes realizem papel similar em sua respectiva estrutura. Segundo o autor, a percepção de um isomorfismo entre duas estruturas conhecidas é um avanço significativo no conhecimento, tal percepção é que cria o significado ou sentido na mente das pessoas.

Se a metáfora e a metonímia são processos isomórficos, então, são, também, processos de conhecimento, ou de conceitualização do mundo, como afirmam Lakoff e Johnson.

A metáfora e a metonímia são tipos de processos diferentes. A metáfora é principalmente uma maneira de conceber uma coisa em termos de outra e sua função primária é a compreensão. A metonímia, por sua vez tem, primariamente, uma função referencial, isto é, que permite usar uma entidade por outra e não representa uma relação meramente referencial, desempenha também a função de proporcionar compreensão (LAKOFF e JOHNSON).

Entende-se o topônimo em seu aspecto dêitico enquanto organiza e estrutura o espaço em que vivemos, as metáforas orientacionais, assim como os topônimos, estão relacionados com a orientação espacial: acima/abaixo, dentro /fora, frente/atrás, profundo/ superficial, central/periférico. As metáforas espacializadoras têm suas raízes na experiência física e cultural, não sendo atribuídas aleatoriamente.

${ }^{57}$ HOFSTADTER, D.; Gödel, Escher Bach: An Eternal Gold Braid. Penguins Books. London, England, 1980, p.49. 
caminho intitulado da Vargem no pé do Morro Grande, córrego da Figueira(...) cujo sitio fabriquei em Mattos fazendo o seu demarco, córrego acima confinando com terras de João Benedito, e o demais lado há certão ( Livro de Terras de Xiririca, apud, Cadernos do ITESP 2, 2000,p.72).

$\mathrm{Na}$ região pesquisada, foram encontrados os seguintes topônimos: Bombas de Cima e Bombas de Baixo, como nomes de comunidades quilombolas, o conceito orientacional está explícito nesses topônimos. Demarcar o lugar tendo como eixo a verticalidade. Também deparou-se com a questão do rio como o grande caminho da região, um caminho que pode ser parte da memória mítica daquela população, pois foi por meio dele que os primeiros habitantes conquistaram o lugar. A expressão "rio acima", "rio abaixo" é parte do conceptus orientacional da população local.

Mandei buscar aos matto (...) que estão pella Ribeira acima, 12 a 15 dias de viagem, em canoas (Cadernos do ITESP 3, 2000, p. 88).

Como seres físicos, limitados e separados do resto do mundo pela superfície de nossa pele, experimenta-se o mundo como algo de fora. Lakoff e Johnson afirmam que toda a experiência parte da perspectiva de ser um recipiente com uma superfície limitada e uma orientação dentro e fora. Portanto, o meio físico que rodeia é também concebido como um recipiente com interior e exterior. As habitações, as casas são recipientes. Ir de uma habitação a outra é ir de um recipiente a outro.

Nesse sentido, o ambiente natural também é concebido sob esta orientação. Segundo os autores, uma clareira em um bosque tem algo que se percebe como uma superfície que o limita e que se vê de dentro ou fora dela, dentro do bosque ou fora do bosque. A 
clareira no bosque é concebida como tendo uma fronteira natural a área imprecisa em que as árvores mais ou menos desaparecem e a clareira mais ou menos começa. Portanto, mesmo onde não há limites naturais precisos o indivíduo coloca esses limites, delineando territórios de maneira que tenham um interior e uma superfície que os limite, quer um muro, uma cerca, uma linha ou um plano abstrato. Para Norberg-Schulz (1980), as fronteiras de um espaço construído são conhecidas como chão, muro, teto. As fronteiras de uma paisagem são estruturalmente similares e consistem em solo, horizonte e céu. Esta similaridade nos remete à identificação entre o espaço natural e o cultural (man-made). As metáforas são também uma forma de conceitualizar o espaço natural baseado em nossa experiência com o espaço cultual. $O$ Petar é conceitualizado como um espaço fechado e com fronteiras bem definidas. Como já foi explicitado anteriormente, é comum dizer-se que se está dentro do Petar ou se está fora dele.

Um conceito importante no contexto dessa pesquisa abordado por Lakoff e Johnson é o de que há poucos instintos humanos mais básicos do que a territorialidade. Eles afirmam que definir um território, colocar uma fronteira ao seu redor é um ato de quantificação. Os autores explicitam que objetos limitados sejam seres humanos, rochas ou extensões de terra, têm tamanho. Isso os faz passíveis de serem quantificados em termos da quantidade de substância que comportam.

Os topônimos Praia Grande, Apiaí Guaçú, Chapéu Mirim, pressupõem uma abordagem quantitativa do lugar.

Substâncias também podem ser vistas como recipientes. Em um balde cheio de água, tanto o balde como a água são considerados como recipientes. O balde é o objeto recipiente e a água é uma substância recipiente. 
O dar nome aos lugares pressupõe entender o lugar como recipiente e tudo o que ocupa esse lugar como substancia. No Petar, diz-se as cavernas do Petar, pressupondo-se que estejam dentro do recipiente Petar. Ou fiquei trabalhando dentro do Petar. O parque é concebido como um recipiente.

"Nesses últimos vinte anos foi um processo de esvaziamento completo e não parou ainda não, tem muita gente indo embora pode ter certeza", como diz Mamute, morador do Bairro da Serra (SILVEIRA, 2001). O Bairro da Serra é concebido como recipiente e os moradores como substancia.

De modo semelhante, o campo visual é conceitualizado como um recipiente e o que vemos, como algo que está dentro deste recipiente. $O$ termo campo visual pode ser visto como uma metáfora natural que surge do fato de que quando se olha um território (terra, solo etc.), tal campo de visão define uma fronteira, isto é, a parte que você pode ver (LAKOFF e JOHNSON, 1980).

Outro aspecto abordado pelos autores é o de que os acontecimentos, ações, atividades e estados podem ser compreendidos como metáforas. Os acontecimentos e as ações se conceitualizam metaforicamente como objetos; as atividades, como substâncias; e os estados, como recipientes. Uma vez que se identifica as experiências como objetos ou substâncias, que podem ser referidas, categorizadas, agrupadas e quantificadas e, dessa maneira, pode-se pensar sobre elas.

Nesse sentido, Norberg-Schulz (1980) diz que o homem habita um determinado local quando ele pode orientar-se dentro, no interior, ou no meio e identificar-se com o ambiente, quando ele experiencializa o ambiente como significativo para si.

Personificação é quando se atribui a objetos físicos qualidades humanas, ver algo não humano como humano. O ponto 
discutido por Lakoff e Johnson é que a personificação é uma categoria que cobre uma ampla gama de metáforas cada uma das quais escolhe aspectos diferentes de uma pessoa, ou modos ou maneiras de olhar uma pessoa. O que todas têm em comum é que nos permite dar sentido a fenômenos do mundo em termos humanos - termos que podem ser entendidos baseando-se nas próprias motivações, objetivos, ações e características.

Se o meio ambiente não vai permitir que o povo do mato trabalhe como sempre trabalhou é justo que lhes pague então um salário (SILVEIRA, 2001, p.166).

O fogo foi provocado por uma pessoa que tinha raiva do meio ambiente (SILVEIRA, 2001, p. 179).

Cuberto de matos, despido de tantas cazas e rancharias, sem a pastaria de gados (Livro de Tombo da Paróquia de Xiririca, apud Cadernos do ITESP, 3, 2000, p.68).

Os topônimos de certa forma são a personificação do espaço, pois, de acordo com Norberg-Schulz, o lugar é um espaço com caráter, levando-se em conta o conceito de genius loci, que seria o espírito do lugar, portanto a personificação por excelência. Os antigos romanos acreditavam que todo ser 'independente' tem seu genius, seu espírito guardião. Este espírito dá vida às pessoas e lugares, acompanha-as do nascimento à morte e determina seu caráter e essência. O genius denota, o que a coisa é, ou o que ela quer ser. $O$ homem antigo experimentava seu ambiente como consistindo de caráter. Em particular, ele reconhecia a importância de lidar com o genius do local onde sua vida acontecia (NORBERG-SCHULZ, 1980, p. 18).

Atualmente, há nas redes sociais, em especial no Facebook e Twiter, a personificação por excelência. Há participantes que acrescentaram, pelos mais variados motivos, como um 
"sobrenome" o topônimo Petar ou Iporanga, ou mesmo Petar Iporanga, com isso procuram agregar traços significativos do topônimo em si ou incorporar a seu nome traços da "personalidade do lugar" (o genius loci). Adicionar Petar e ou Iporanga ao nome próprio de pessoa pressuporia a personificação do lugar, tornandoo parte do indivíduo. Nesse sentido, há a identificação do indivíduo com traços significativos do lugar. No caso do Petar, esses traços poderiam (ou deveriam) ser a preservação ambiental, a valorização do ambiente natural com florestas, rios, cachoeiras, cavernas etc. Quando o topônimo é Iporanga, pode-se pensar em conceitos que levem em conta a historiografia, pois a história de Iporanga traduz significados referentes a um passado de opulência relativos à descoberta do ouro na região. O Vale do Ribeira foi o primeiro local a se explorar o ouro no Brasil. Com a chegada de Martin Afonso, em 1534, a primeira bandeira parte da região do Vale e segue sertão à dentro em busca das ricas minas de ouro, expedição essa que nunca retornou, sendo atacada e dizimada pelos índios da etnia carijó, moradores da região abaixo de Cananeia. Portanto, desde a chegada de Martim Afonso, a região já era conhecida como região aurífera. A quantidade de ouro retirada da região foi bastante significativa para a época, dando origem à cidade de Registro, onde o ouro era registrado antes de ir para fundição na cidade de Iguape. Esse ideal mítico de que a região foi o grande eldorado brasileiro é perceptível no contato com os moradores, pois muitos acreditam que há ainda muito ouro na região.

No corpus do presente trabalho, foi encontrado um número significativo de topônimos de origem indígena, grande parte deles da língua tupi, que se acredita datarem de antes da chegada dos europeus àquela região, isto é, antes do século XVI. Esses 
denominativos, em sua maioria, mantêm com o lugar denominado uma relação de contiguidade, isto é, relações metonímicas.

Metonymy is a cognitive process in which one conceptual entity, the vehicle, provides mental access to another conceptual entity, the target, within the same domain, or idealized cognitive model (KÖVECSES, 2002).

(rio) Y-chiririca > água ligeira, a corredeira.

(rio) Taquari, Taqual- í > cana pequena, ou fina.

(ribeirão) Brejaúva > ybyrayá-ybá - árvore de madeira rígida

Quando um rio é denominado como Y-Chiririca, percebe-se que a escolha do nome se deu ao se priorizar um trecho desse rio, a parte pedregosa e cheia de correntezas. Como diz Lakoff e Johnson (1980), a escolha não é arbitrária, há muitos trechos do rio que poderiam ter essa função referencial, mas, ao priorizarem essa parte para representar o todo, o rio, destacaram os aspectos mais significativos em seu convívio com aquele ambiente natural, na verdade conceitualizam, metonimicamente, o lugar em que viviam, isto é, apreenderam o lugar por meio de processos metonímicos e/ou metafóricos.

De acordo com Norberg-Schulz, para que os lugares tenham significado é necessário que se estabeleça um sistema estável que demande uma estrutura imaginária e que essa ofereça ricas possibilidades de identificação. Acredita-se que a escolha de um ponto do rio para representar o todo seja parte da construção da estrutura significativa da paisagem. Os topônimos indígenas exprimem o íntimo convívio do homem com a natureza, esse relacionamento íntimo com a natureza pressupõe o habitar (dwell) que envolve as duas funções psicológicas, a orientação e a identificação. Para alcançar uma base existencial o homem tem de ser capaz de se orientar, ele tem de saber onde está. Mas ele 
também tem de se identificar com o ambiente, isto é, ele tem de saber como ele está no ambiente. Para o autor, identificação significa se tornar "amigo" do ambiente (NORBERG-SCHULZ, 1965, 1980).

A maioria dos topônimos indígenas apresenta um tipo de metonímia principalmente a parte pelo todo, como exemplificado anteriormente, isto é, um dado do ambiente, ou do "objeto" a ser denominado, representando esse objeto como um todo e, assim, sendo reconhecido por toda comunidade. Nesse sentido, entendese a metonímia também como um processo metafórico, já que traços significativos de uma determinada parte do objeto passam a representar todo o objeto. Esses semas são transferidos ao objeto como um todo gerando uma mudança de sentido, o rio já não é só um rio, mas, agora, é compreendido como rio de corredeiras, ou rio com taquaras, ou rio da árvore de madeira dura. A representação mental dos habitantes é feita em relação ao objeto descrito pelo nome.

Searle (1993) entende a metonímia e a sinédoque como casos especiais de metáfora:

I can, for example, refer to the British monarch as "The Crow", and the executive branch of the U.S. government as "the White House" by exploiting systematic principles of association. However, as I said, the claim that these are special cases of metaphor seems to me pure terminology, and if purists insist that the principles of metaphor be kept separate from those of metonymy and synecdoche, I can have no nontaxonomical objections (p. 433).

Nesse sentido, pode-se afirmar que todo nome de lugar ou mesmo nome de pessoa possui intrinsecamente um conceptus metafórico/metonímico: a representação de um objeto complexo 
como um lugar ou uma pessoa, repleto de significados, por um único nome.

Tal abordagem é justificada ao retomar-se um ponto já discutido anteriormente 0 de que os nomes são escolhas motivadas. Partindo-se do princípio de que a escolha se dá no nível de discurso ocorrência, considerado na singularidade e na unicidade de sua manifestação, quando o léxico já é parte de um contexto significativo. Portanto, essa escolha pressupõe alguma associação significativa entre o nome e o referente que será denominado. A escolha de Iporanga (rio bonito) para denominar a cidade não foi arbitrária. A cidade está localizada no ponto exato da confluência do ribeirão Iporanga com o rio Ribeira do Iguape. O rio mais significativo seria o Ribeira, é maior e, durante muito tempo, foi a principal via de ligação de Iporanga com o resto do mundo. Os traços significativos dessa escolha tem por base a memória que 0 ribeirão carrega, pois fora em suas margens que construíram a primeira capela no local onde havia um ponto de garimpo, 0 garimpo Santo Antonio. A escolha foi pelo menor rio, mas o mais significativo para a população da cidade.

Pode-se concluir que essa escolha contempla semas que identificam a comunidade com o lugar, ou, como diz NorbergSchulz, para que um lugar se torne significativo é preciso haver identificação e orientação. O topônimo ribeirão Iporanga agrega além dos semas intrínsecos ao campo semântico rio (fonte de vida, pois proporciona alimento e água, vitais para a sobrevivência) associa também semas relativos à historia da comunidade, nesse sentido é identidade. Rio é caminho, ligação de um lugar a outro, portanto, é também orientação. Desse maneira, o topônimo seria uma metáfora/metonímia da população, a parte pelo todo, ou seja, 
esse topônimo é representativo de valores os quais a população se reconhece e quer ser reconhecida.

Reddy $^{58}$ (apud LAKOFF, 1993) mostrou que o locus da metáfora é o pensamento, não a linguagem, que a metáfora é a maior parte e a parte indispensável da maneira usual e convencional de como se conceitualiza o mundo. Acredita-se que os nome de lugares são parte de nossa conceitualização do mundo, funcionam como frames que segundo Lakoff (1993) "are mental structure that shape the way we view the world". Os topônimos seriam mais que simples palavras eles teriam a função de desencadear esquemas que "seriam padrões conceituais ou imagens abstratas que subjazem às palavras" (PALMER, 1996).

Nesse contexto, os topônimos agregariam a função de frames e esquemas, pois como afirma Norberg-Schulz (1980), desenvolvemos as relações com os objetos que estruturam o ambiente durante a infância. As crianças crescem em espaços verdes, marrons ou brancos, caminham ou brincam na areia, na terra, na pedra, na grama, sob um céu nublado ou sob um céu aberto; agarram e levantam coisas leves e pesadas; ouvem barulhos, tais como o som do vento movendo as folhas de uma árvore particular; experimentam o frio e o calor. Elas, portanto, adquirem conhecimento em sua relação com o ambiente e, a partir desse conhecimento, desenvolvem frames e esquemas que determinarão todas as suas futuras experiências. Evidentemente, todos os seres humanos processam frames e esquemas de orientação e identificação em relação ao ambiente em que se interrelacionam.

\footnotetext{
58 REDDY, M. apud LAKOFF. The contemporary theory of metaphor. In Metaphor and Thought, edited by Andrew Ortony. Cambridge University Press. 1993.
} 
A pessoa desenvolve a identidade em termos de frames e esquemas ambientais, pois determinam o mundo que está acessível, ou melhor, o ambiente ao qual se relacionam. Quando uma pessoa quer dizer quem ela é, é comum dizer, "sou brasileiro", ou "sou carioca" ou, ainda, "sou nordestino". Isso é muito mais do que dizer "sou professor" ou, talvez, "sou otimista" (NORBERGSCHUZ, 1980).

Entende-se que a identidade humana é, em larga medida, uma função de lugar e coisas. O importante não é somente que o ambiente tenha uma estrutura espacial na qual se possa orientar, o mais importante é que essa estrutura seja constituída de objetos de identificação.

Por exemplo, quando digo "sou são-carlense" para amigos paulistanos, por ter nascido em São Carlos; além do aspecto geográfico de localização, há embutida nessa afirmação traços conceituais que remetem a uma visão de mundo que foi construída a partir das primeiras experiências com o espaço ao redor, quando passei a reconhecer os limites do meu corpo e do entorno em que vivia. Um simples cheiro ou um barulho qualquer podem desencadear lembranças profundas que remetem à construção do "eu" (self). A maneira como vejo e experimento o mundo hoje não pode ser desvinculada desses frames e esquemas que são as estruturas mentais que definem e significam o modo como sou e estou no mundo.

Tzventan Todorov diz: "meu passado Búlgaro é muito importante para mim, mas eu não vivo mais na Bulgária, é a Bulgária que vive dentro de mim" 59 .

\footnotetext{
${ }^{59}$ TODOROV,T. Meu passado em mim. Disponível em: http://www.youtube.com/watch?v=ELqFMYYul-A\&feature=youtu.be Acessado em: 14 abril 2013.
} 
Em Iporanga, dizem "sou iporangueiro" contrapondo à “iporanguense”, que é geográfico.

Clayton Lino explica:

Dizem, "sou Iporangueiro", forma específica de definir não só um lugar de origem, mas também, uma cultura diferenciada e que tem embutida uma indiscutível autoestima, tipo mineiro, carioca. Iporanguense é geografia, Iporangueiro é cultura ${ }^{60}$.

Iporangueiro, portanto, agrega orientação e identidade. O sufixo -eiro/eira diferente de ense, combina traços que definem um núcleo semântico de pertencer a um grupo restrito ao qual é exigido algumas características específicas para ser parte do grupo, não tem a mesma conotação que iporanguense que tem como traço significativo ser natural de, ou melhor,ter nascido em Iporanga. Iporangueiro, ao contrário, define outros traços significativos como compartilhar uma visão de mundo com um determinado grupo, mantém relação com palmiteiro, mateiro,balseiro, canoeiro, gruteiro etc. Todos esses termos remetem a um fazer muito específico da região. Iporangueiro seria, portanto, o gentílico característico daquela região e é um neologismo que tem uma base metonímica e metafórica com um lugar específico, o Alto Ribeira.

Como processo metonímico, pode-se estabelecer que o ser se compreende como parte do lugar a que pertence, o sentimento de pertencimento seria a raiz da metonímia, ser parte de. Já a metáfora se explicaria por meio do sufixo eiro /-eira, que faz a ponte semântica com as representações construídas pelo grupo. Pode-se arriscar a dizer que Iporagueiro mais do que ser de Iporanga traduz traços que combinam com o ecoturismo, ligado às práticas de

\footnotetext{
${ }^{60}$ Cayton Lino é arquiteto e presidente da Reserva da Biosfera da Mata Atlântica, convive com a comunidade de Iporanga desde os anos 80 e participou da implantação do Petar. Depoimento colhido em viagem ao Petar em 2012.
} 
esportes radicais que a região oferece como explorar cavernas, praticar rafting, fazer trilhas em regiões acidentadas, fazer rapel em cachoeiras e, acima de tudo, engajado ao ambiente natural da região e aos valores que aquela sociedade agrega e preserva.

Pode-se, portanto, dizer que Iporangueiro seria frame e esquema, pois define uma visão de mundo e, ao se auto denominarem Iporangueiros criam padrões conceituais de significação restritos ao grupo, e que estão presentes no léxico. 


\section{Estabelecimento do corpus de análise. Metodologia}

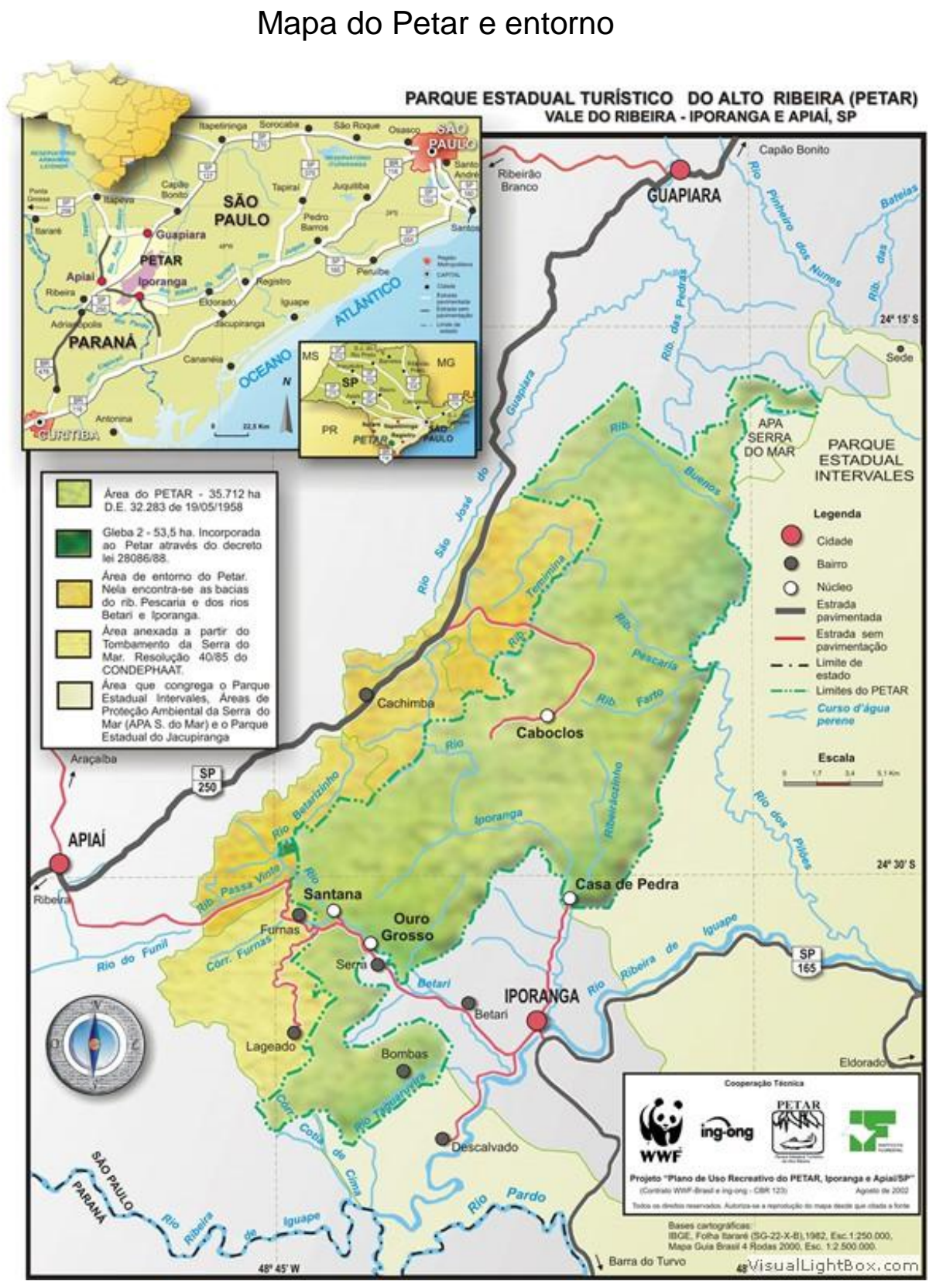




\subsection{Metodologia do Projeto Atesp}

A importância do estudo dos nomes de lugar tem um sentido especial no contexto dessa pesquisa, pois conceitualiza-se 0 espaço como parte de nossa própria estrutura mental. O lugar é uma categoria importante que participa da elaboração das relações que se mantém com o mundo, ou, melhor, a maneira como se apreende o ambiente à volta.

Como visto no capítulo anterior, a região do Petar, o Alto Ribeira, tem uma historiografia riquíssima. Ali encontra-se ainda uma população que experiencializou um jeito de viver característico da formação da sociedade brasileira, modelos sociais já praticamente extintos não só no Estado de São Paulo, mas talvez até no Brasil, ainda se fazem presentes ali. A memória de um passado que foi importante na construção da identidade étnica nacional ainda não se perdeu por completo na região do Alto Ribeira. Os moradores, em especial os mais velhos, conseguem repetir histórias de como os primeiros habitantes chegaram, quem eram, que relações tinham com o espaço, com a comunidade.

Dona Antonia, moradora de Bombas, conta:

minha avó, minha tataravó, foi pegada a laço, ela era bugre, sabi? [...] então nós somu raça de índiu, de índiu, se criamu na roça, sabemu tudu u qui fazê di roça, somu geração de índiu ${ }^{61}$.

No Alto Ribeira, como já dito, depara-se com os estratos étnicos mais significativos na construção da sociedade brasileira: 0 indígena, o negro e o europeu. Os relatos sobre a ocupação do espaço explicitam essa convivência inter-racial, são histórias que não devem ser esquecidas pois são elas que mantém o estreito

61 Um Lugar chamado Bombas. Documentário filmado na comunidade de Bombas em 2004 por Luis Flavio Terra Hungria. Disponível em http://vimeo.com/52203692. Acessado em 04.07.2013. 
vínculo entre os moradores e o lugar, tornando o lugar parte significativa na construção de sua identidade. Como diz NorbergSchulz (1980), é necessário que o lugar seja significativo para que possamos nos identificar e nos orientar.

Nesse sentido, uma das funções dos estudos toponímicos é manter esse vínculo que liga a comunidade ao lugar, formando um corpo único do qual o indivíduo se senta parte. Os nomes de lugar são parte da construção dessa memória coletiva que pode até ser mítica, ou melhor, que deve se transformar em uma memória mítica, para que se tenha um passado comum que é a base da construção do "eu social", parte das representações de mundo, isto é, metáforas conceituais. É nesse contexto que se entende os topônimos como metáforas conceituais, pois pertencer a um lugar/grupo do mundo define as relações que se mantém com o meio circundante, ou melhor, dá significado a essas relações.

A presente pesquisa é parte do projeto Atesp, Atlas Toponímico do Estado de São Paulo, integrante do Atlas Toponímico do Brasil. Um dos objetivos do Atlas é o levantamento da nomenclatura geográfica dos 645 municípios do Estado de São Paulo. O Petar como uma das mais importantes Unidades de Conservação do Estado de São Paulo se insere ao Atesp, trazendo novas configurações em termos de análise toponímica.

A implantação do Petar, como uma Unidade de Conservação de Proteção Integral ${ }^{62}$, teve início, como visto, a partir da década de 1980, quando sua área foi demarcada e as restrições de uso aos

\footnotetext{
${ }^{62}$ Uma Unidade de Conservação de Proteção Integral pressupõe apenas o uso indireto de seus recursos naturais em atividades como pesquisa científica e turismo ecológico e não podem ser habitadas pelo homem. Unidades de Conservação de Uso Sustentável tem como objetivo compatibilizar a conservação da natureza com o uso sustentável dos recursos naturais e admitem a presença de moradores. Disponível em http://dema.policiacivil.pa.gov.br/?q=content/\%C3\%A1reas-protegidas Acessado em 23.06.2013.
} 
recursos naturais começaram a ser impostas. A população do entorno do Parque, em especial os moradores de bairros rurais que foram afetados diretamente por essas restrições, Bairro da Serra, Bombas e todos os que estavam inseridos nesse contorno, sofreram diretamente 0 impacto dessa mudança. Consequentemente, a toponímia da região passa a refletir traços dessa transformação.

Nesse sentido, o Parque Estadual Turístico do Alto Ribeira como integrante do Atesp, sugere novas concepções para a análise do signo toponímico. Esses novos conceitos pressupõem uma abordagem contemporânea de lugar no qual conceitos como preservação ambiental, uso sustentável dos recursos naturais, comunidades tradicionais, ecoturismo, entre outros, interferem no fazer denominativo. Desse modo, é necessário levar em conta essas novas configurações de lugar que propõem mudanças nas relações do homem com o território e nos quais o meio ambiente, a paisagem natural e a paisagem cultural entram como um valor a ser preservado para que as novas gerações possam se beneficiar de tais valores.

A implantação do Parque suscitou duas questões antagônicas para a comunidade da região de Iporanga: como sobreviveria aquela comunidade que dependia quase que exclusivamente de uma agricultura e pecuária de subsistência em um entorno com restrições severas de uso da terra? A segunda questão é como fazer que essa comunidade se apropriasse desse novo modelo e fosse, ela mesma, o principal agente das políticas de preservação ambiental? A solução consistiria em que os benefícios trazidos pelo turismo do Petar, em especial as novas opções de trabalho, fossem, primeiramente, oferecidas à comunidade local. Esta foi uma forma de amenizar as restrições sofridas em suas práticas 
tradicionais tais como o extrativismo, tanto o mineral como o vegetal, as roças de coivara, a criação de animais etc.

A grande questão que se levanta hoje é: de que modo as comunidades tradicionais podem conviver com áreas preservadas? $E$, até que ponto os benefícios trazidos pelo turismo irão acolher toda a comunidade do entorno?

É nesse contexto, em que a comunidade mundial levanta questões sobre as limitações dos recursos naturais do planeta e a necessidade de se criar uma política de preservação ambiental, que o Petar se insere no Atlas. O desafio de se manter grandes áreas naturais preservadas pressupõe outro modelo de apropriação do lugar, e a toponímia de certa forma permite acompanhar essa complexidade histórica e cultural.

\subsubsection{O projeto Atesp}

O Projeto ATESP - Atlas Toponímico do Estado de São Paulo - integrante do Atlas Toponímico do Brasil, fundamenta-se principalmente em cartas municipais paulistas ou mapas elaborados pelo Instituto Geográfico e Cartográfico de São Paulo. Objetiva o levantamento da nomenclatura geográfica dos 645 municípios ${ }^{63}$, tanto em relação aos acidentes físicos quanto aos culturais. O Atlas busca verificar a tipologia motivadora pertinente a determinadas áreas e inscrevê-las em folhas cartográficas específicas, fornecendo uma visão panorâmica geral das designações.

A base da pesquisa do projeto ATESP é o topônimo concretamente manifestado, buscando a etimologia das formas linguísticas. Esta etimologia define um critério de tipificações toponímicas estabelecido por Dick (1996) nas quais as ocorrências

${ }^{63}$ Informação atualizada no site IBGE CIDADES@ em 2010. 
linguísticas de origem portuguesa devem ser marcadas na cor azul, as etimologias de origem indígena na cor vermelha, as de origem africana em marrom e, nomes híbridos na cor verde.

Os estudos toponímicos foram sistematizados segundo dois pontos de vista básicos:

- o aspecto linguístico que absorve o campo etnodialetológico e o campo histórico-cultural.

- o aspecto taxionômico, que envolve as categorias toponímicas.

$\mathrm{Na}$ perspectiva etnolinguística, o topônimo recebe influência dos estratos da linguagem falada, das camadas portuguesa, indígena (no estado de São Paulo o tupi predomina) e da africana, além de uma combinatória do português-tupi; e tupi-português, caracterizando as formações híbridas ou mistas (DICK. 1990).

De acordo com Dick (1990), no estado de São Paulo, a nomenclatura das unidades administrativas está coerente com os focos de irradiação étnica. A distribuição areal dessas camadas denominativas mostra que, a sudeste e a sudoeste do Estado, se localizam os municípios de fundação mais antiga, constituindo as primeiras vilas e povoados advindos da colonização portuguesa iniciada no litoral, no século XVI. Cidades costeiras, tanto ao norte quanto ao sul, e, até mesmo, aquelas mais recuadas, na direção ao interior, são da época dos primeiros aldeamentos indígenas.

Os topônimos revelam a trajetória contínua de sua permanência, desde o Quinhentismo e o Seiscentismo até os tempos atuais: Iguape, Itanhaém, Peruíbe, Monguaguá, Guarujá, Bertioga, Guarulhos, Itapecerica, Embu, Barueri, Carapicuíba, Mogi, Pirapora, Itu. No Alto Ribeira tem-se Xiririca, atual Eldorado, que era uma aldeia indígena quando os primeiros exploradores chegaram. 
No campo histórico cultural, registros como época de criação dos municípios, identificação dos fundadores, situação geográfica, função social do lugar, recursos econômicos, meios de exploração, sistema legal de terras, primeiros estabelecimentos, são fatores importantes para a fundamentação da primeira nomenclatura, aquela que, ao traduzir a ideologia dominante do grupo, comandará a distribuição das camadas denominativas supervenientes em suas transformações, substituições ou retornos (DICK, 1990).

Do ponto de vista do ordenamento normativo, o Projeto segue as taxionomias constituídas por Dick (1980), baseadas nas duas ordens genéricas que agrupam os fatos cósmicos entre si, as manifestações físicas naturais (chamadas geográficas) e as antropoculturais (construídas pelo homem). Cada uma delas comporta uma seriação tipológica específica.

As categorias taxionômicas compreendem 27 taxes de índices onomásticos, as quais objetivam verificar os principais motivos geradores de nomes do país e a elaboração de uma terminologia específica à área. São as taxionomias toponímicas que revelam a ponte semântica entre o lugar e o nome do lugar e, consequentemente, a motivação no ato denominativo. Apesar de elas privilegiarem os aspectos denotativos contidos no termo específico do sintagma toponímico, a relação entre o denominador e o nome é sempre uma relação subjetiva, pois pressupõe a contextualização e a mediação entre o símbolo e o que se quer representar, convertendo o que se quer representar em parte do mundo do designador ou designadores. Dentro desse contexto, o lugar, ou melhor, o nome do lugar, passa a ser uma metáfora do que se quer representar, portanto, pode-se dizer que a motivação é parte de um processo metafórico e, ou metonímico, ou seja, 
associação e, ou, contiguidade do que se quer representar, o lugar, com o signo, o topônimo.

As taxes procuram satisfazer as ocorrências onomásticas pondo em evidência conceitos como o dos arquétipos toponímicos (DICK, 1986) e das variáveis culturais dos nomes descritivos e comemorativos (STEWART, 1954) ou do jogo de oposições entre a subjetividade do denominador, respeitadas as variáveis étnicas, e a objetividade ambiental (DICK, 1996).

Pela pesquisa diacrônico-constrativa de análise toponímica, é possível atingir questões além do próprio ato de nomeação e a indicação de fatores que levaram à utilização de tal designativo. Pode-se chegar ao entendimento da ocupação dos grupos humanos, seu papel frente a outros grupos e, mesmo, a função de indivíduos nessa organização social.

Segue-se o processo onomasiológico de pesquisa dos nomes de lugar, partindo-se da primeira enunciação que singularize o espaço até sua configuração como topônimo propriamente dito. Isso porque, pela identificação das formas de nomeação mais remotas, da modificação na forma e no significado desses nomes, de substituições de certa nomenclatura em detrimento de outra, é possível estabelecer os modos de pensar e de agir em determinada região.

Assim, dentro do universo dos estudos toponímicos, as taxionomias seriam os termos por excelência, pois definem um campo de conhecimento especializado.

\subsubsection{Taxionomias Toponímicas:}

Dentro da perspectiva de busca das tendências motivadoras da toponímia paulista, fez-se referência a dois campos genéricos condicionadores do mecanismo da doação do nome, a saber, o 
campo objetivo ou extrínseco, externo ao denominador, e o campo subjetivo ou intrínseco, "que comporta a sua visão personalíssima de entender o local" (DICK 1990). No primeiro caso, transporta-se para a nomenclatura geográfica uma série de motivos que encontram sua razão de ser no ambiente ou meio circundante. Nos topônimos de origem indígena, normalmente descritivo, este vínculo entre o denominador e o ambiente ou meio circundante é bastante característico, marcado, principalmente, por relações metonímicas.

Por exemplo: rio Xiririca.

Y-chiririca - água ligeira, veloz, a corredeira

No outro, todavia, são motivações pessoais do denominador, aparentemente inexplicáveis. Nessas é mais difícil definir os motivos que levaram o denominador, em um processo de escolha paradigmática, a selecionar designações cuja razão determinante não se atinge à primeira vista, caracterizadas, muitas vezes, por relações metafóricas. Como exemplo temos: córrego Inveja.

O objetivo do Atlas Toponímico do Estado de São Paulo é a verificação das tendências motivadoras da toponímia paulista para o estabelecimento do modelo-padrão desses toponomásticos e, as circunstâncias do ato denominativo.

Se a realidade é apenas uma, cada pessoa a vê de forma diferenciada; dessa forma, a visão pelo homem das coisas materiais é sempre deformada. Nossa tarefa é a de ultrapassar a paisagem como aspecto, par chegar ao seu significado. A percepção não é ainda o conhecimento, que depende de sua interpretação e esta será tanto mais válida quanto mais limitarmos o risco de tomar por verdadeiro o que é só aparência (SANTOS, 1988, p.62)

Nesse sentido, a proposição de Milton Santos, tornou-se fundamental no presente trabalho que é a análise e interpretação 
da paisagem, partido sempre, da visão do denominador (em um sentido genérico e não o sentido personalista da lexia). Um dos objetivos do Atlas Toponímico é a interpretação do que é a vida nas diferentes regiões, "de seus funcionamentos específicos, de suas especializações, de suas relações, enfim de seu arranjo particular" para chegar-se à totalidade do processo que molda, para a compreensão da realidade total. A relação social, por mais parcial ou pequena que pareça, contém parte das relações que são globais.

A presente pesquisa está inserida nessa sistemática metodológica do Projeto ATESP. Por meio do estudo dos nomes de lugar, procurou-se demonstrar as fontes motivadoras e delinear um padrão nos denominativos na região do Petar, inseridos aí os bairro rurais e as cidades de Iporanga e Apiaí.

\section{Taxionomias de natureza física :}

1. Astrotopônimos: topônimos relativos aos corpos celestes em geral.

2. Cardinotopônimos: topônimos relativos às posições geográficas em geral.

3. Cromotopônimos: topônimos relativos à escala cromática.

4. Dimensiotopônimos: topônimos relativos às características dimensionais dos acidentes geográficos como extensão, comprimento, largura, grossura, altura, profundidade.

5. Fitotopônimos: topônimos de índole vegetal, espontânea, em sua individualidade, em conjuntos da mesma espécie, ou de espécies diferentes, além de formações não espontâneas.

6. Geomorfotopônimos: topônimos relativos às formas geográficas. 
7. Hidrotopônimos: topônimos resultantes de acidentes hidrográficos em geral.

8. Litotopônimos: topônimos de índole mineral relativos à constituição do solo, representados por indivíduos, conjunto da mesma espécie, ou de espécies diferentes.

9. Meteorotopônimos: topônimos relativos a fenômenos atmosféricos.

10. Morfotopônimos: topônimos que refletem o sentido de formas geométricas.

11. Zootopônimos: topônimos de índole animal, representados por indivíduos domésticos não domésticos e da mesma espécie.

\section{Taxionomias de natureza antropocultural}

12. Animotopônimos ou nootopônimos: topônimo relativo à vida psíquica, á cultura espiritual, abrangendo todos os produtos do psiquismo humano.

13. Antropotopônimos: topônimos relativos aos nomes próprios individuais.

14. Axiotopônimos: topônimos relativos aos títulos e dignidades que se fazem acompanhar os nomes próprios individuais.

15. Corotopônimos: topônimos relativos aos nomes de cidades, países, estados, regiões, continentes.

16. Cronotopônimos: topônimos que encerram indicadores cronológicos representados em toponímia pelos adjetivos novo/nova, velho/velha.

17. Ecotopônimos: topônimos relativos às habitações de um modo geral.

18. Ergotopônimos: topônimos relativos a elementos da cultura material. 
19. Etnotopônimos: topônimos relativos aos elementos étnicos, isolados ou não.

20.Dirrematotopônimos: topônimos constituídos por frases ou enunciados lingüísticos.

21. Hierotopônimos: topônimos relativos aos nomes sagrados de diferentes crenças, às associações religiosas, às efemeridades religiosas, às associações religiosas, aos locais de culto.

Os hierotopônmos se subdividem em:

21a. Hagiotopônimos: topônimos referentes aos santos e santas do hagiologioromano.

21b. Mitotopônimos: topônimos relativos às entidades mitológicas.

22. Historiotopônimo: topônimos relativos aos movimentos de cunho social e a seus membros, assim como as datas correspondentes.

23. Hodotopônimos (Odotopônimos): topônimos relativos às vias de comunicação rural ou urbana.

24. Numerotopônimo: topônimos relativos aos adjetivos numerais.

25. Poliotopônimo: topônimos constituídos pelos vocábulos vila, aldeia, cidade, povoação, arraial..

26. Sociotopônimo: topônimos relativos às atividades profissionais, aos locais de trabalho, e aos pontos de encontro de membros de uma comunidade.

27. Somatotopônimo: topônimos empregados em relação metafórica às partes do corpo humano ou animal.

\subsection{Delimitação do espaço}

Trabalhou-se com um entorno complexo, primeiramente com denominativos que datam dos primórdios da colonização ou, até mesmo antes da chegada dos europeus; a ocupação do Alto Vale do Ribeira marcada pela expressiva presença da comunidade 
negra e o relativo isolamento dessas sociedades em bairros rurais traçou especificidades na toponímia local, isto é, a denominação levava em conta os grupos familiares. A implantação do Parque Estadual Turístico do Alto Ribeira modifica as relações do morador local com o território e traz uma nova configuração para a região. Há um novo recorte do espaço que não deve mais ser ocupado pelo homem, a denominação, nessa fase, leva em conta os acidentes físicos, em especial cavernas, trilhas, cachoeiras, havendo, portanto, uma mudança na perspectiva do fazer denominativo.

A fim de estabelecer os parâmetros que justifiquem o signo toponímico como um dado cultural e também como um componente da formação das identidades da comunidade local, contou-se, na presente coleta de dados, com o testemunho de moradores locais, principalmente os mais antigos, que agregaram informações ricas em relação aos denominativos. Conversou-se com o Sr Joaquim Justino, o JJ, o primeiro guia da região, acompanhou os pesquisadores da mineração de chumbo e os primeiros espeleólogos, em especial Peirre Matin, Le Bret e Guy Collet nos anos de 1950 e 1960. Seu conhecimento da região, em especial as cavernas são reconhecidos até hoje pelos exploradores locais e estudiosos da área.

O Sr Arabelo e sua família, moradores antigos da região, também colaboraram com informações preciosas a respeito da ocupação e exploração do entorno de Iporanga. Dona Eunice, mãe das professoras Eunice e Soraia, auxiliou demasiadamente ao contar como era a dinâmica da vida comunitária de Iporanga em sua infância e juventude.

A escola e seus professores em especial, sua diretora, Prof ${ }^{\underline{a}}$ Eunice, sua irmã, a Prof ${ }^{\mathrm{a}}$ Soraia, já mencionadas anteriormente, e 
Milena, professora de geografia, foram colaboradores valiosas na coleta de dados. Sr. Alberto, pesquisador da história de Iporanga, morador local também ajudou a elucidar dados complexos destas análises.

As visitas às comunidades quilombolas de Ivapurunduva, Nhunguara, Sapatu e Praia Grande assessoradas pela Prof ${ }^{\underline{a}}$ Soraia e pelo arquiteto e espeleólogo Clayton Lino mudaram a presente visão do que é uma comunidade quilombola e ajudou a compreender melhor o sentido de identidade étnica, de conservação cultural e direito ao território.

Conversou-se com os líderes comunitários de Ivapurunduva, Sr. Benedito e Sr. Olavo que descreveram o processo por que toda a comunidade passou até o seu reconhecimento oficial como comunidade quilombola e a obtenção do título das terras em 2010.

Ao visitar-se o Parque, suas cavernas e a mata preservada em seu entorno, o contato que se teve com os guias ambientais, também moradores da região, que hoje têm parte de seu sustento garantido pelo turismo oferecido pela implantação do parque, também foram fundamentais para se entender a complexa configuração que se propôs a estudar nesta tese.

A base de nossa pesquisa se deu pelo IF - Instituo Florestal e pelo ITESP - Fundação Instituto de Terras do Estado de São Paulo, o levantamento historiográfico e antropológico forneceu uma bibliografia rica para o estabelecimento do corpus da tese.

A sede administrativa do Petar, localizada em Apiaí, foi a fonte de dados tanto da constituição do Parque e do Plano de Manejo (Lei no 9.985/2000 que estabelece o Sistema Nacional de Unidades de Conservação define o Plano de Manejo como um documento técnico mediante o qual, com fundamento nos objetivos gerais de uma Unidade de Conservação, se estabelece o seu zoneamento e 
as normas que devem presidir o uso da área e o manejo dos recursos naturais.) como, também, cedeu alguns mapas que são base importante da pesquisa toponímica.

Contou-se com a colaboração da Reserva Betary, que disponibilizou um dos mapas com o qual parte significativa do corpus foi elencado.

Optou-se por trabalhar também com os topônimos que estão no entorno do Parque e não só aqueles inseridos na área do Petar. Entende-se que o sentido se dá em relação a um contexto, no caso, a concepção toponímica do Parque só se explica em relação ao entorno; o Parque foi concebido em uma região já ocupada e com uma historiografia densa e muito antiga como visto anteriormente. Tanto os acidentes físicos como os acidentes humanos foram considerados nesta análise. 


\section{Análise dos dados}

\subsection{Análise quantitativa}

O corpus é composto por 180 topônimos que abrangem tanto os acidentes físicos (AF) quanto os acidentes humanos $(\mathrm{AH})$. $\mathrm{O}$ entorno do Parque é constituído por bairros rurais ou sítios que estão inseridos na paisagem natural, como os rios, as serras, as cachoeiras.

As taxes relacionadas às manifestações físicas apresentam: 30 zootopônimos, 18 hidrotopônimos, 16 litotopônimos, 14 geomorfotopônimo, 12 fitotopônimo, 4 cromotopônimos; aquelas relacionadas às manifestações antropoculturais: 28 antropotopônimo, 12 ergotopônimo, 8 hagiotopônimo, 5 etnotopônimo, 4 animotopônimo, 4 sociotopônimo e 4 dirrematotopônimo.

As demais taxes apresentam de um a dois topônimos em cada classe, sendo pouco representativas, como pode ser visto na figura abaixo. 
Incidência dos diferentes tipos de topônimos que aparecem no Petar e entorno

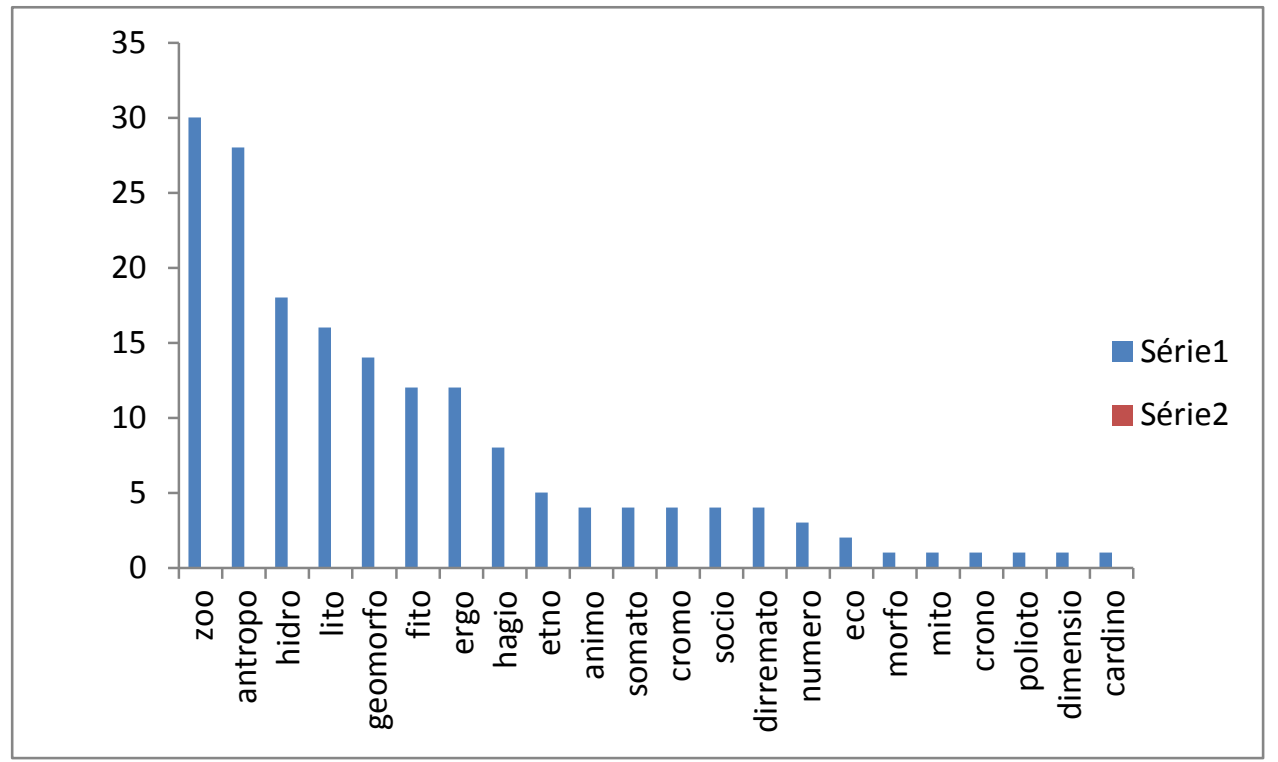

\subsubsection{Apresentação do corpus de análise}

Optou-se por elencar todos os topônimos em uma única tabela em ordem alfabética, por entender que facilitaria o trabalho de consulta.

Encontrou-se casos em que um mesmo topônimo referencializa diferentes acidentes em um processo que se pode chamar de expansão do termo específico do sintagma toponímico; ocorrências como rio Betari, bairro Betari não configurariam um caso de homonímia mas sim de polissemia, pois o referente principal, o rio, é o mesmo; portanto, sempre que o referente principal for o mesmo, preferiu-se manter a mesma entrada e especificar os tipos de acidentes que acompanham o nome. Nesse sentido, seguiu-se a proposta do Projeto Atesp, que se baseia, principalmente, na motivação toponímica e não, necessariamente, no acidente geográfico. 
Os dados apresentados estão de acordo com a proposta do Projeto Atesp e, dessa forma contribuirão para a constituição do mapa toponímico da região do Alto Ribeira; os topônimos em português estão marcados na cor azul, os indígenas em vermelho, os africanos em marrom e os híbridos em verde. Neste corpus, foi encontrado um topônimo que não pertencia a nenhuma dessas categorias (em língua espanhola), optou-se por introduzir uma nova cor, o amarelo, para caracterizá-lo. A base de dados foi definida pelos mapas já elencados e, portanto, comporta o Parque Estadual Turístico do Alto Ribeira e seu entorno, abrangendo parte dos municípios de Iporanga e Apiaí, pois o Parque está contido nos dois municípios.

A localização dos principais acidentes físicos (AF) e acidentes humanos $(\mathrm{AH})$ consta do mapa apresentado acima.

Tabela 1: Lista, em ordem alfabética e classificada por tipo de acidentes, etimologia e taxionomia, dos topônimos do corpus constituído ao longo desta pesquisa

\begin{tabular}{|c|c|c|c|c|c|}
\hline Ord. & Topônimo & Tipos de acidentes & Etimologia & Acidente & Taxionomia \\
\hline 1 & Abóboras & córrego das & Portugues & AF & Fitotopônimo \\
\hline 2 & Água Suja & caverna & Português & AF & Hidrotopônimo \\
\hline 3 & Água Sumida & caverna & Português & AF & Hidrotopônimo \\
\hline 4 & $\begin{array}{c}\text { Agudos } \\
\text { Grandes }\end{array}$ & serra dos & Português & AF & Geomorfotôponimo \\
\hline 5 & Alambari & rio & Tupi & AF & Zootopônimo \\
\hline 6 & $\begin{array}{c}\text { Alambari de } \\
\text { Baixo }\end{array}$ & caverna & Tupi/Port. & AF & Zootopônimo \\
\hline 7 & $\begin{array}{c}\text { Alambari de } \\
\text { Cima }\end{array}$ & caverna & Tupi/Port. & AF & Zootopônimo \\
\hline 8 & Alegre & ribeirão do & Português & AF & Animotopônimo \\
\hline 9 & Almas & $\begin{array}{c}\text { rio das } \\
\text { serra das, córrego } \\
\text { das, cachoeira das, }\end{array}$ & Português & AF e AH & Zootopônimo \\
\hline 10 & Andorinhas & Português & AFônimo \\
\hline 11 & André & $\begin{array}{c}\text { abismo do } \\
\text { rio, serra, } \\
\text { quilombola }\end{array}$ & Português & AF & Antropotopônimo \\
\hline 12 & André Lopes & AF e AH & Antropotopônimo \\
\hline
\end{tabular}




\begin{tabular}{|c|c|c|c|c|c|}
\hline 13 & Anhanguara & bairro & Tupi & $\mathrm{AH}$ & Geomorfotôponimo \\
\hline 14 & Anta & córrego da & Porturguês & AF & Zootopônimo \\
\hline 15 & Anta Gorda & serra da, ribeirão & Português & AF & Zootopônimo \\
\hline 16 & Apiaí & cidade & Tupi & $\mathrm{AH}$ & Etnotopônimo \\
\hline 17 & Apiaí Guaçú & rio & Tupi & AF & Etnotopônimo \\
\hline 18 & Aranhas & $\begin{array}{l}\text { córrego das, gruta } \\
\text { das }\end{array}$ & Português & $\mathrm{AF}$ & Zootopônimo \\
\hline 19 & Arapongas & $\begin{array}{c}\text { córrego, cachoeira } \\
\text { das, bairro }\end{array}$ & Tupi & $\mathrm{AF}$ e $\mathrm{AH}$ & Zootopônimo \\
\hline 20 & Arataca & gruta da & Tupi & AF & Ergotopônimo \\
\hline 21 & Areado & ribeirão,bairro & Português & $\mathrm{AF}$ e $\mathrm{AH}$ & Litotopônimo \\
\hline 22 & Areias & córrego, caverna & Português & AF & Litotopônimo \\
\hline 23 & $\begin{array}{l}\text { Banhado } \\
\text { Grande }\end{array}$ & bairro & Português & $\mathrm{AH}$ & Hidrotopônimo \\
\hline 24 & Batalha & córrego & Português & $\mathrm{AF}$ & Antropotopônimo \\
\hline 25 & Baú & serra do, bairro do & Português & $\mathrm{AF}$ e $\mathrm{AH}$ & Ergotopônimo \\
\hline 26 & Bernardo & córrego do & Português & $\mathrm{AF}$ & Antropotopônimo \\
\hline 27 & Betari & $\begin{array}{l}\text { rio, vale, bairro, } \\
\text { reserva }\end{array}$ & Tupi & $\mathrm{AF}$ e $\mathrm{AH}$ & Hidrotopônimo \\
\hline 28 & Betarizinho & rio, cachoeira do & Tupi/Port. & $\mathrm{AF}$ & Hidrotopônimo \\
\hline 29 & Biquinha & serra da & Português & $\mathrm{AF}$ & Hidrotopônimo \\
\hline 30 & Boa Vista & serra da & Portugês & $\mathrm{AF}$ & Dirrematotopônimo \\
\hline 31 & Bocó & rio & Tupi & $\mathrm{AF}$ & Zootopônimo \\
\hline 32 & Bombas & $\begin{array}{c}\text { córrego, comunidade } \\
\text { quilombola }\end{array}$ & Português & $\mathrm{AF}$ e $\mathrm{AH}$ & Somatotopônimo \\
\hline 33 & Branco & rio & Português & $\mathrm{AF}$ & Cromotopônimo \\
\hline 34 & Brejaúva & ribeirão & Tupi & $\mathrm{AF}$ & Fitotopônimo \\
\hline 35 & Bucuva & córrego & Tupi & AF & \\
\hline 36 & Cabana & caverna & Português & $\mathrm{AF}$ & Ecotopônimo \\
\hline 37 & Caboclos & $\begin{array}{c}\text { serra dos, bairro, } \\
\text { núcleo }\end{array}$ & Tupi/Port. & $\mathrm{AF}$ e $\mathrm{AH}$ & Etnotopônimo \\
\hline 38 & Cachimba & córrego da, bairro da & Quimbumdo & $\mathrm{AF}$ e $\mathrm{AH}$ & Ergotopônimo \\
\hline 39 & cafesal & caverna & Português & $\mathrm{AF}$ & Fitotopônimo \\
\hline 40 & Camargos & bairro dos & Português & $\mathrm{AH}$ & Antropotopônimo \\
\hline 41 & Campina & córrego & Português & $\mathrm{AF}$ & Geomorfotôponimo \\
\hline 42 & Canhambora & $\begin{array}{c}\text { córrego, bairro, } \\
\text { reserva }\end{array}$ & Tupi/Quimbundo & $\mathrm{AF}$ e $\mathrm{AH}$ & Etnotopônimo \\
\hline 43 & Capuava & córrego & Tupi & $\mathrm{AF}$ & Sociotopônimo \\
\hline 44 & Caracol & bairro do, córrego & Português & $\mathrm{AF}$ & Morfotopônimo \\
\hline 45 & Carmo & ribeirão do & Português & $\mathrm{AF}$ & Antropotopônimo \\
\hline 46 & Casa de Pedra & caverna, núcleo & Português & $\mathrm{AF}$ e $\mathrm{AH}$ & Ecotopônimo \\
\hline 47 & Chapéu & gruta do & Português & $\mathrm{AF}$ & Ergotopônimo \\
\hline
\end{tabular}




\begin{tabular}{|c|c|c|c|c|c|}
\hline 48 & Claro & rio & Português & $\mathrm{AF}$ & Cromotopônimo \\
\hline 49 & Cogumelos & caverna & Português & $A F$ & Fitotopônimo \\
\hline 50 & Conchas & rio das & Português & AF & Zootopônimo \\
\hline 51 & Coral & córrego do & Português & AF & Zootopônimo \\
\hline 52 & Corguinho & fluxo d'água & Português & AF & Hidrotopônimo \\
\hline 53 & Couto & caverna & Português & AF & Antropotopônimo \\
\hline 53 & Cristal & gruta & Português & AF & Litotopônimo \\
\hline 55 & Cutia & córrego & Tupi & AF & Zootopônimo \\
\hline 56 & Cutia de Cima & córrego & Tupi/Portu. & AF & Zootopônimo \\
\hline 57 & Descalvado & bairro & Português & $\mathrm{AH}$ & Somatotopônimo \\
\hline 58 & Desmoronada & caverna & Português & AF & Geomorfotôponimo \\
\hline 59 & Dúvida & serra da, bairro da & Português & $\mathrm{AF}$ e $\mathrm{AH}$ & Animotopônimo \\
\hline 60 & Engenho Farto & gruta do & Português & $\mathrm{AF}$ & Ergotopônimo \\
\hline 61 & Espírito Santo & $\begin{array}{c}\text { córrego, bairro, } \\
\text { reserva }\end{array}$ & Português & $\mathrm{AF}$ e $\mathrm{AH}$ & Hagitopônimo \\
\hline 62 & Feital & bairro, córrego do & Port. & $\mathrm{AF}$ e $\mathrm{AH}$ & Litotopônimo \\
\hline 63 & Forquilha & bairro & Português & AF & Ergotopônimo \\
\hline 64 & Fundo & córrego & Português & $\mathrm{AF}$ & Hidrotopônimo \\
\hline 65 & Funil & rio do & Português & AF & Ergotopônimo \\
\hline 66 & Furnas & bairro de, caverna & Português & AF & Geomorfotôponimo \\
\hline 67 & Furquim & córrego & Português & $\mathrm{AF}$ & Antropotopônimo \\
\hline 68 & Galvão & córrego & Português & AF & Antropotopônimo \\
\hline 69 & Gastãozinho & gruta & Português & AF & Antropotopônimo \\
\hline 70 & Gino & córrego do & Português & AF & Antropotopônimo \\
\hline 71 & Grande & serra, córrego & Português & AF & Dimensiotopônimo \\
\hline 72 & Gurutuva & serra, abismo & Tupi & $\mathrm{AF}$ & Zootopônimo \\
\hline 73 & Inferno & córrego do & Português & AF & Mitotopônimo \\
\hline 74 & Iporanga & ribeirão, rio, cidade & Tupi & $\mathrm{AF}$ e $\mathrm{AH}$ & Hidrotopônimo \\
\hline 75 & Itacolomy & ribeirão & Tupi & $\mathrm{AF}$ & Litotopônimo \\
\hline 76 & Ivaporunduva & $\begin{array}{c}\text { rio, comunidade } \\
\text { quilombola }\end{array}$ & Tupi & $\mathrm{AF}$ e $\mathrm{AH}$ & Fitotopônimo \\
\hline 77 & Jacu & córrego do & Tupi & AF & Zootopônimo \\
\hline 78 & Jaguatirica & córrego da & Tupi & AF & Zootopônimo \\
\hline 79 & Jararacuçú & gruta & Tupi & $\mathrm{AF}$ & Zootopônimo \\
\hline 80 & Jeremias & caverna & Português & $A F$ & Antropotopônimo \\
\hline 81 & João Ferreira & serra & Português & AF & Antropotopônimo \\
\hline 82 & $\begin{array}{l}\text { Joaquim } \\
\text { Justino }\end{array}$ & gruta do & Português & AF & Antropotopônimo \\
\hline 83 & Juvenal & caverna & Português & AF & Antropotopônimo \\
\hline
\end{tabular}




\begin{tabular}{|c|c|c|c|c|c|}
\hline 84 & Laboratório & gruta do & Português & AF & Sociotopônimo \\
\hline 85 & Laje Branca & gruta & Português & AF & Litotopônimo \\
\hline 86 & Lajeado & bairro & Português & $\mathrm{AH}$ & Litotopônimo \\
\hline 87 & Lambari & córrego & Tupi & $\mathrm{AF}$ & Zootopônimo \\
\hline 88 & Lambari & córrego do & Português & AF & Zootopônimo \\
\hline 89 & Lição №1 & gruta & Português & AF & Numerotopônimo \\
\hline 90 & Limoeiro & córrego & Português & AF & Fitotopônimo \\
\hline 91 & $\begin{array}{l}\text { Los Tres } \\
\text { Amigos }\end{array}$ & gruta & Espanhol & $\mathrm{AF}$ & Numerotopônimo \\
\hline 92 & Macacos & serra dos & Português & $\mathrm{AF}$ & Zootopônimo \\
\hline 93 & Manduri & gruta & Tupi & $\mathrm{AF}$ & Zootopônimo \\
\hline 94 & Maria Rosa & $\begin{array}{l}\text { comunidade } \\
\text { quilombola }\end{array}$ & Português & AF & Antropotopônimo \\
\hline 95 & Marinhos & córrego dos & Português & AF & Antropotopônimo \\
\hline 96 & Marreca & gruta da & Português & AF & Zootopônimo \\
\hline 97 & Marreta & gruta da & Português & $\mathrm{AF}$ & Ergotopônimo \\
\hline 98 & Martins & córrego do & Português & $\mathrm{AF}$ & Antropotopônimo \\
\hline 99 & Maximiniano & $\begin{array}{c}\text { córrego do, cachoeira } \\
\text { do }\end{array}$ & Português & AF & Antropotopônimo \\
\hline 100 & Minas & córrego & Português & AF & Litotopônimo \\
\hline 101 & Monjolinho & córrego, gruta, bairro & Português & $\mathrm{AF}$ e $\mathrm{AH}$ & Ergotopônimo \\
\hline 102 & Monte Alegre & córrego & Português & $\mathrm{AF}$ & Geomorfotopônimo \\
\hline 103 & Monte Negro & serra & Português & $\mathrm{AF}$ & Geomorfotopônimo \\
\hline 104 & Moquém & ribeirão & Tupi & AF & Ergotopônimo \\
\hline 105 & Morcego & córrego do & Português & $\mathrm{AF}$ & Zootopônimo \\
\hline 106 & $\begin{array}{c}\text { Morcego } \\
\text { branco }\end{array}$ & gruta do & Português & AF & Zootopônimo \\
\hline 107 & $\begin{array}{l}\text { Morro do } \\
\text { Chumbo } \\
\end{array}$ & bairro & Português & $\mathrm{AH}$ & Geomorfotopônimo \\
\hline 108 & Morro Grande & córrego & Português & AF & Geomorfotopônimo \\
\hline 109 & Morro Preto & serra do, gruta & Português & $\mathrm{AF}$ & Geomorfotopônimo \\
\hline 110 & Nhunguara & $\begin{array}{c}\text { comunidade } \\
\text { quilombola } \\
\end{array}$ & Tupi & $\mathrm{AH}$ & Geomorfotopônimo \\
\hline 111 & Novo & rio & Português & AF & Cronotopônimo \\
\hline 112 & Onça Parda & serra da, abismo & Português & $\mathrm{AF}$ & Zootopônimo \\
\hline 113 & Ouro Grosso & rio, caverna, núcleo & Português & $\mathrm{AF}$ & Litotopônimo \\
\hline 114 & Pacas & córrego das & Tupi & AF & Zootopônimo \\
\hline 115 & Paciência & serra & Português & $\mathrm{AF}$ & Animotopônimo \\
\hline 116 & Paçoca & córrego, abismo & Tupi & AF & Ergotopônimo \\
\hline 117 & Padre & rio do & Português & AF & Sociotopônimo \\
\hline 118 & Paivas & caverna & Português & $\mathrm{AF}$ & Antropotopônimo \\
\hline
\end{tabular}




\begin{tabular}{|c|c|c|c|c|c|}
\hline 119 & Palmital & ribeirão & Português & $\mathrm{AF}$ & Fitotopônimo \\
\hline 120 & Parado & bairro do & Português & $\mathrm{AH}$ & Antropo/Sociotopônimo \\
\hline 121 & Paranapanema & rio & Tupi & $\mathrm{AF}$ & Hidrotopônimo \\
\hline 122 & Paranapiacaba & serra & Tupi & AF & Geomorfotôponimo \\
\hline 123 & Pardo & rio & Português & AF & Cromotopônimo \\
\hline 124 & Passa Vinte & ribeirão, bairro & Português & AF & Dirrematotopônimo \\
\hline 125 & \begin{tabular}{|c|}
$\begin{array}{c}\text { Passagem do } \\
\text { Meio }\end{array}$ \\
\end{tabular} & bairro & Português & $\mathrm{AH}$ & Dirrematotopônimo \\
\hline 126 & Pedra & córrego das & Português & AF & Litotopônimo \\
\hline 127 & $\begin{array}{l}\text { Pedra de } \\
\text { Amolar }\end{array}$ & córrego & Português & AF & Litotopônimo \\
\hline 128 & Pedra de Fogo & bairro da & Português & $\mathrm{AH}$ & Litotopônimo \\
\hline 129 & Pedra Santa & serra da & Português & AF & Litotopônimo \\
\hline 130 & Pedras & rio da & Português & AF & Litotopônimo \\
\hline 131 & Pedro Cubas & $\begin{array}{c}\text { rio, comunidade } \\
\text { quilombola }\end{array}$ & Português & $\mathrm{AF}$ e $\mathrm{AH}$ & Antrotopônimo \\
\hline 132 & Pérolas & caverna & Português & AF & Zootopônimo \\
\hline 133 & Pescaria & ribeirão,caverna & Português & $\mathrm{AF}$ & Sociotopônimo \\
\hline 134 & Pianos & bairro dos & Português & $\mathrm{AH}$ & Ergotopônimo \\
\hline 135 & Pilões & $\begin{array}{c}\text { rio, comunidade } \\
\text { quilombola } \\
\end{array}$ & Português & $\mathrm{AF}$ e $\mathrm{AH}$ & Ergotopônimo \\
\hline 136 & Pinheirinho & córrego & Português & AF & Fitotopônimo \\
\hline 137 & Pinheiro Nunes & rio & Português & AF & Antropotopônimo \\
\hline 138 & Piririca & & Tupi & $\mathrm{AH}$ & Hidrotopônimo \\
\hline 139 & $\begin{array}{l}\text { Porto dos } \\
\text { Pilões }\end{array}$ & bairro & Português & $\mathrm{AH}$ & Sociotopônimo \\
\hline 140 & Praia Grande & $\begin{array}{c}\text { comunidade } \\
\text { quilombola }\end{array}$ & Português & $\mathrm{AH}$ & Hidrotopônimo \\
\hline 141 & Preto & rio & Português & AF & Cromotopônimo \\
\hline 142 & $\begin{array}{c}\text { Ribeira do } \\
\text { Iguape }\end{array}$ & rio & Port./Tupi & AF & Hidrotopônimo \\
\hline 143 & Ribeirão & bairro & Português & $\mathrm{AH}$ & Hidrotopônimo \\
\hline 144 & Ribeirãozinho & fluxo d'água, bairro & Português & $\mathrm{AF}$ e $\mathrm{AH}$ & Hidrotopônimo \\
\hline 145 & Rodrigues & ribeirão & Português & $\mathrm{AF}$ & Antropotopônimo \\
\hline 146 & Roncador & córrego & Português & AF & Somatotopônimo \\
\hline 147 & Rubuquara & bairro & Tupi & $\mathrm{AH}$ & Zootopônimo \\
\hline 148 & Saltinho & bairro & Português & $\mathrm{AH}$ & Hidrotopônimo \\
\hline 149 & Samambaia & serra da, bairro & Tupi & $\mathrm{AF}$ e $\mathrm{AH}$ & Fitotopônimo \\
\hline 150 & Santa Rita & córrego & Português & AF & Hagitopônimo \\
\hline 151 & Santana & $\begin{array}{c}\text { órrego, caverna, } \\
\text { núcleo }\end{array}$ & Português & $\mathrm{AF}$ e $\mathrm{AH}$ & Hagitopônimo \\
\hline 152 & Santo Antonio & rio e bairro & Português & $\mathrm{AF}$ e $\mathrm{AH}$ & Hagitopônimo \\
\hline 153 & São José do & rio & Port./Tupi & AF & Hagio/Geomorfotopônimo \\
\hline
\end{tabular}




\begin{tabular}{|c|c|c|c|c|c|}
\hline & Guapiara & & & & \\
\hline 154 & São Paulo & rio & Português & $\mathrm{AF}$ & Hagitopônimo \\
\hline 155 & São Pedro & ribeirão & Português & AF & Hagitopônimo \\
\hline 156 & São Sebastião & rio & Português & $\mathrm{AF}$ & Hagitopônimo \\
\hline 157 & $\begin{array}{l}\text { Sebastião } \\
\text { Machado }\end{array}$ & córrego & Português & $\mathrm{AF}$ & Antropotopônimo \\
\hline 158 & Sem Fim & serra do, córrego do & Português & AF & Dirrematotopônimo \\
\hline 159 & Serra & bairro da & Português & $\mathrm{AH}$ & Geomorfotôponimo \\
\hline 160 & Sete Reis & cachoeira & Português & $\mathrm{AF}$ & Numerotopônimo \\
\hline 161 & Sítio Novo & bairro & Português & $\mathrm{AH}$ & Poliotopônimo \\
\hline 162 & Soares & córrego do, bairro do & Português & $\mathrm{AF}$ e $\mathrm{AH}$ & Antropotopônimo \\
\hline 163 & Sophia & gruta & Português & $\mathrm{AF}$ & Antropotopônimo \\
\hline 164 & Sulino & serra do & Português & AF & Cardiotopônimo \\
\hline 165 & Taluá & bairro & Tupi & $\mathrm{AH}$ & Antropotopônimo \\
\hline 166 & Taquari Mirim & rio & Tupi & AF & Fitotopônimo \\
\hline 167 & Taquaruvira & cachoeira & Tupi & AF & Fitotopônimo \\
\hline 168 & Tatu & gruta do & Tupi & $\mathrm{AF}$ & Zootopônimo \\
\hline 169 & Temimina & $\begin{array}{c}\text { rio, cavernas e base } \\
\text { de fiscalização }\end{array}$ & Tupi & $\mathrm{AF}$ e $\mathrm{AH}$ & Etnotopônimo \\
\hline 170 & Tentativa & abismo & Português & $\mathrm{AF}$ & Animotopônimo \\
\hline 171 & Terra Boa & córrego & Português & AF & Litotopônimo \\
\hline 172 & Tijuco & ribeirão & Tupi & $\mathrm{AF}$ & Litotopônimo \\
\hline 173 & Tobias & caverna & Português & AF & Antropotopônimo \\
\hline 174 & Três Águas & córrego & Português & AF & Hidrotopônimo \\
\hline 175 & Tubaca & abismo & Tupi & $\mathrm{AF}$ & Zootopônimo \\
\hline 176 & Tude/Tudo & bairro do, córrego do & Português & $\mathrm{AF}$ e $\mathrm{AH}$ & Antropo/Dirrematotopônimo \\
\hline 177 & $\begin{array}{l}\text { Vamos } \\
\text { Embora }\end{array}$ & córrego & Português & $\mathrm{AF}$ & Dirrematotopônimo \\
\hline 178 & $\begin{array}{l}\text { Vargem } \\
\text { Grande } \\
\end{array}$ & serra & Português & $\mathrm{AF}$ & Geomorfotôponimo \\
\hline 179 & Xaxim & córrego & Tupi & $\mathrm{AF}$ & Fitotopônimo \\
\hline 180 & Xiririca & rio & Tupi & $\mathrm{AF}$ & Hidrotopônimo \\
\hline
\end{tabular}




\subsection{Análise Qualitativa}

\subsubsection{Percurso da análise do corpus}

A implantação do Petar, como Unidade de Conservação Permanente na região de Iporanga, demarcou uma nova apropriação do espaço. Como consequência, ao se descrever a análise do corpus de pesquisa, optou-se por classificar os topônimos sob uma perspectiva diacrônica, ou seja, levando-se em conta os dados históricos de ocupação do lugar. Definiu-se três camadas denominativas, isto é, três etapas que caracterizam a ocupação do lugar. A primeira etapa relaciona-se aos denominativos que pressupomos existam antes da chegada dos europeu, seriam os nomes de lugar predominantemente de origem indígena. A segunda etapa configura a chegada do europeu e da comunidade negra à região do Alto Ribeira, em meados do século $\mathrm{XVI}$ e século XVII. A última etapa trata da implantação de Unidades de Conservação na região, provocando um novo recorte espacial como consequência das propostas de preservação ambiental. Essa fase data do início do século XX, quando as cavernas começaram a ser exploradas e denominadas; primeiramente os objetivos eram arqueológicos, com Edmund Krug e, a partir de meados dos anos de 1950, com foco na espeleologia, marcada principalmente pela presença dos franceses, Pierre Martin, Michel Le Bret e Guy Collet.

De acordo com o pressuposto, dividiu-se a análise em três direções que podem ser concomitantes, a motivação toponímica perpassa todos os períodos e, de certa forma, é ela que explicita as diferentes interações do homem com o lugar.

Entende-se as taxionomias toponímicas como metáforas e, ou metonímias das relações do homem com o meio ambiente, ou, segundo Kövecses (2006), seriam disparadores das associações e ou contiguidades contidas nos denominativos de lugar que atuam 
no sentido de contextualizar a comunidade no lugar para que se apropriem do espaço e se identifiquem com o território tornando-o significativo. (NORBERG-SCHULZ, 1980). As camadas denominativas explicitam as relações que, em diferentes épocas, o homem manteve com o lugar, as motivações justificam essas relações, ao classificar-se os denominativos de acordo com as taxes toponímicas, pontua-se as interações importantes da população local com o meio ambiente.

\subsubsection{Denominativos de origem tupi}

Os nomes de origem indígena, os mais antigos, que se pressupõe existam antes mesmo da chegada dos europeus, ou façam parte de um tempo em que havia uma língua comum usada tanto pelos europeus quanto pelos indígenas, chamada língua geral, ou tupi antigo.

Até o começo do século XVIII, a proporção entre as duas línguas faladas na colônia era mais ou menos de três para um, do tupi para o português. Em algumas capitanias, como São Paulo, Rio Grande do Sul, [...] onde a catequese mais influiu, o tupi prevaleceu por mais tempo ainda. Nas duas primeiras falava-se entre os homens do campo, a língua geral até o fim do século XVII (TEODORO SAMPAIO, 1987, p.69).

Esses denominativos confirmam a história da ocupação da região do Vale do Ribeira que, de acordo com pesquisas históricas e arqueológicas, comprovariam que ali não seria um vazio demográfico antes da chegada dos europeus como fora considerado. Achados de sambaquis fluviais na região do vale do 
Betari, em Iporanga, atestam a presença humana há, pelo menos, cinco mil anos (BLASIS, 2003) ${ }^{64}$.

A riqueza implícita nesses denominativos como memória viva de um passado impossível de ser descortinado em sua totalidade, requer que sejam preservados como marcos de uma história passada da formação do povo brasileiro, plural, indígena, negro e europeu. O significado de cada um desses topônimos reflete as paisagens únicas que, no Vale do Ribeira, podem ainda ser encontradas no ambiente local e apresentar ecos com um passado já muito distante, sendo hoje considerado até mesmo mítico, que surge na imaginação de todos que visitam o Petar e sua mata exuberante.

Levy Cardoso ${ }^{65}$ afirmava que, por meio do conhecimento das etimologias, alcançava-se o significado que os "primitivos senhores da terra davam em épocas muitas vezes anteriores a conquista cabralina", seriam os topônimos que revelam em sua tradução a "admirável lucidez de nosso silvícola nas suas denominações geográficas" (1960, p.19).

No presente corpus, conseguiu-se identificar topônimos, em sua maioria de origem tupi, remanescentes das primeiras ocupações na região. Talvez, como sugerira Levy Cardoso, antes da chegada dos europeus ao continente americano. Muitos desses topônimos podem ser encontrados em textos de documentação antiga, do século XVI e XVII, em especial aquelas que tratam da compra ou venda de terras. Reproduzimos parte de documento de

\footnotetext{
${ }^{64}$ Blasis,Paulo Antonio Dantas de. Os Sambaquis fluviais do Vale do Ribeira de Iguape: evidências intra e extra-sítio. São Paulo: Sociedade de Arqueologia Brasileira, 2003.

${ }^{65}$ CARDOSO,Levy.Toponímia Brasílica, Biblioteca do Exercito Editora, Rio de Janeiro, 1960.
} 
1655, citado por Young ${ }^{66}$. Em tal excerto, encontrou-se os denominativos: Iporanga (Upurunga) Apiaí ( Piahy) e Ivapurunduva (vupuranduba), demonstrando que os europeus, ao chegarem à região, encontraram a paisagem já denominada por seus primeiros habitantes. Ou, no mínimo, o documento comprova uma relação muito próxima entre europeus e a comunidade indígena, sugerindo que muito provavelmente compartilharam uma linguagem comum.

$1^{\circ}$ uma sociedade [de domingos Rodrigues Cunha ] com seu Irmão Antonio Rodrigues Cunha em huma lavra que comprarão com dez escravos do defunto Antonio Soares de Azevedo em cuja trabalhava serviço braçal e ao mesmo tempo feitorizando os escravos todo por tempo de hum anno.

$2^{\circ}$ Que o dito se irmão Antonio Rodrigues Cunha andava o mais do tempo fora da lavra ficando so o suplicante nella e so na apuração das catas lavando ouro e como caixa o distribuía.

$3^{\circ}$ Que elle achando-se nas lavras de Upuranga anno e mejo em todo este tempo anda va em cobrança do sitio de seu Irmão fazendo os gastos e da custa e em três viagens que fizera as minas do Piahy a huma cobranço de Capp. Mór Fran. Alves Marinho sem o dito seu Irmão Ihe desse desgostos.

$4^{\circ}$ Que elle sup. Trabalhando nas lavras de Sercabas por perssuação do dito Irmão e de Deonisio d"Oliveira o qual se empenhou a seduzillo $p^{\underline{a}}$ vir $p^{\underline{a}}$ esta Villa afim de conseguir a sociedade em que lhe mandara fallar.

Mandando vir fazendo do Rio para o Sup negociar com Ella com effeito viher a dita.

$5^{\circ}$ Que desertando o Sup. Das lavras de vupuranduba d'onde se achava minerando estivera nesta Villa lutando hum anno e o cabo delle faltando lhe ao ajuste se deliberou o Sup. A tornar $\mathrm{p}^{\mathrm{a}}$. As ditas lavras de vupuranduba.

As etimologias tupi estão fundamentadas nos estudos de Teodoro Sampaio, em especial, na obra, O Tupi na Geografia Nacional.

${ }^{66}$ YOUNG, E. Esboço Histórico da Fundação da Cidade de Iguape. 1895 apud Cadernos do Itesp 3, 2000. P. 66. 


\section{Alambari}

Alambari - Araberi, árabe-r-i, a baratinha, o peixinho, a sardinha. Alt. lambary [lambari]

Nome de rio e cavernas situado no Núcleo Ouro Grosso no Petar.

O processo metonímico expresso no topônimo Alambari ou Lambary, apresenta relação da parte pelo todo. O peixe, abundante em parte, ou, em todo o rio, representa o rio como um todo. Segundo Lakoff e Johnson ao escolher uma característica particular para representar o todo, evidencia-se relações particulares que se mantém com o todo. Ao denominar um rio com o nome de um peixe supõe-se que o peixe, ou a espécie de peixe, seja de certa forma significativa na vida da comunidade. Nesse sentido, o denominativo não descreve apenas a realidade mas, sim, sugere interações da população como o meio ambiente

Os denominativos das cavernas, Alambari de Cima e Alambari de Baixo, são uma apropriação metonímica do nome do rio, pois é esse o rio que forma as cavernas. Essa apropriação privilegia o rio como aspecto significativo, os semas relacionados ao peixe deixam de ter significado, há portanto uma mudança de sentido. Quando o referente é a caverna, Alambari não é mais peixe e sim rio. $O$ aspecto a ser considerado como relevante para a comunidade que denomina é o rio. Esse dado é coerente com comunidade que denomina as cavernas que são, principalmente, os espeleólogos; a visão desse grupo relacionada ao espaço circundante está focada no objeto caverna e, nesse contexto, nada é mais importante que o rio que desenvolve a caverna.

Nota-se que o sentido original de Alambari se perdeu, o peixe deixou de ser significativo para as comunidades do entorno do 
Parque, mas as cavernas ganharam muita importância com a implantação do Petar, há a possibilidade de futuramente Alambari referendar apenas cavernas, a relação significado /significante pode mudar novamente e Alambari poderá ter outro referente e portanto haverá um novo sentido implícito no denominativo.

Para a comunidade representativa da primeira camada denominativa, os indígenas, o rio era conceitualizado em função dos peixes que viviam nele. No percurso gerativo de sentido desse denominativo para a geração seguinte, o aspecto motivador é o rio. A última camada referencializa muito mais a caverna, portanto, a motivação implícita no topônimo é a caverna. Nesse sentido, Alambari é nome de caverna.

O nome das cavernas Alambari de Baixo e Alambari de Cima estão de acordo com a localização geográfica de cada uma. Portanto, o sentido de acima e abaixo está na relação de reciprocidade que as cavernas mantém.

\section{Apiaí}

Apiaí > Apiahí > Apiá-y - rio dos machos ou dos homens Apiai-y - rio dos meninos

\section{Apiaí- Guaçú (rio)}

Guaçú : uaçu> guaçú - grande, grosso, largo

Apiaí é nome de cidade e rio.

Apiaí é um topônimo tupi. É indicativo de ocupação indígena remota na região como se pode verificar no levantamento historiográfico. Presume-se que existisse antes da chegada dos europeus.

É nome de rio que, segundo Dauzat (1926), os cursos d'água, como elementos permanentes da paisagem, tendem a conservar as denominações primitivas e, assim, constituem elementos preciosos 
na reconstituição de línguas antigas. Configura a primeira camada denominativa coerente com os focos de irradiação étnicas. De acordo com Dick(1990) "é a sudeste e a sudoeste de São Paulo que se localizam os municípios de fundação mais antiga, constituindo as primitivas vilas e povoados uma decorrência da ação colonizadora lusitana, iniciada no litoral (sec. XVI) e depois demandando para o interior."

Pode-se observar na interpretação etimológica de Apiaí que o $y$, indicativo de água ou rio, perdeu seu sentido original, esse fato ocorre em todos os nomes de rios de origem tupi, tais como $Y$ poranga, rio bonito, formoso; Jundiaí, Yundiá-y rio dos jundiás etc. O desconhecimento ou a perda semântica dos elementos constitutivos da língua de partida tem como consequência a sobreposição do termo genérico, acarretando um sentido redundante, mas não mais transparente para a comunidade falante.

De nome de rio, Apiaí passou a denominar o porto, porto de Apiahy, local onde o ouro era abundante na época da mineração.

Vila de Santo Antonio das Minas de Apiahy foi o nome dado ao primeiro povoamento. Em 1892, ao obter o foro de cidade o denominativo reduziu-se a Apiahy. Segundo Dick, essa redução foi uma simplificação ortográfica devido à dificuldade de se colocar em cartas geográficas nomes muito extensos, as abreviações dificultavam a leitura dessas cartas e muitas vezes não era possível interpretá-las corretamente. Além disso, a própria tendência de redução leva a tal simplificação.

A acepção oficial determinada atualmente pela prefeitura de Apiaí é a de rio menino e, não como propõe Teodoro Sampaio, rio dos meninos.

Segundo Dick, a interpretação, rio dos meninos, poderia estar relacionada a rituais que os indígenas praticavam com as crianças 
nesse ponto do rio, ou, ao lugar em que crianças eram sacrificadas. Sabe-se que na região do Vale do Ribeira há cidades que se originaram em local de aldeias indígenas, como Xiririca, atual Eldorado. Ali havia uma aldeia indígena quando os primeiros exploradores chegaram ao local. Pode ter acontecido o mesmo com Apiaí. Como Apiaí estava localizada no sertão, e só era acessada pelos exploradores de ouro, não há registro confiável sobre essa época (meados do século XVI), portanto, pode-se apenas supor a existência de uma aldeia indígena nas proximidades. Nesse sentido, a interpretação do denominativo como local de ritual com crianças é apenas isso, uma interpretação.

A opção feita pela prefeitura de Apiaí por um deslocamento do significado rio dos meninos para rio menino pressupõe uma mudança de sentido. Há nessa nova acepção, um traço que leva a uma conotação poética, lírica sobre o lugar. É compreensível que as prefeituras busquem relacionar o lugar onde vivem seus cidadãos a referentes poéticos. Sabe-se da importância que 0 lugar, em especial o lugar em que se nasce e se cresce, tem na concepção futura do indivíduo em relação ao mundo.

Existe entre Iporanga e Eldorado, um rio chamado rio Meninos. Levy Cardoso (1961) discorre sobre topônimos que são "meras traduções literais de nomenclaturas caribes e aruacas, tal como acontece com o tupi". Acredita-se que o rio Meninos nada mais é que uma tradução de Apiaí.

\section{Araponga}

Araponga : Ara- ponga - alteração de guirá-ponga, o pássaro martelante, cujo som soa como a pancada de um martelo, o ferrador. 
O canto da araponga é emblemático na região do Alto Ribeira, seu canto ecoa pelas serras como uma batida ritmada de martelo em uma superfície metálica.

Araponga é nome de serra, córrego,cachoeira, gruta e bairro no entorno do Petar.

Parte-se do pressuposto de que o acidente físico mais significativo no entorno seja o referente fonte do designativo, no contexto do Petar a serra seria o acidente mais expressivo.

No topônimo, serra da Araponga, usa-se o pássaro araponga para referir-se a serra. A serra é da araponga, acredita-se que arapongas vivam na serra ou cantem sempre na serra; uma parte representativa da serra, o pássaro, que canta ou que mora na serra representa o todo, a serra. Ao denominar uma serra com o nome de um dos muitos pássaros que vivem nessa serra, tais como, tucano, pica-pau, tangará, gavião pombo, viuvinha, e outros, denota a importância desse pássaro na região. De fato, o canto da araponga é simbólico no entorno do Petar.

A ligação do bairro com o nome Arapongas já não pressupõe o pássaro mas o acidente geográfico, a serra, pois o bairro está localizado na região da serra da Araponga; há portanto mudança de sentido, as relações significativas de orientação e identidade são com a serra. Nesse contexto a motivação leva em consideração o acidente e não a ave, teríamos, então, um geomorfotopônimo como taxionomia e não um zootopônimo.

Pode-se dizer que a mudança de sentido seja representativa da segunda camada denominativa. O bairro Arapongas é contiguo ao Petar; a maioria da comunidade está praticamente isolada, com o acesso difícil por trilhas que muitas vezes exigem horas de caminhada. A infraestrutura é precária, não há energia elétrica, 
saneamento básico, escola etc. A atividade econômica se restringe à agricultura de subsistência.

Há estudos para que a área do Lajeado, onde se encontra o bairro Arapongas, se transforme em uma Unidade de Conservação Municipal.

\section{Betari}

Betary : berá - brilhante, cristalino, claro; y-água, rio

A acepção apresentada não está totalmente resolvida, há estudo para encontrar uma forma primitiva da lexia que auxilie a resolver algumas lacunas nada claras. Joaquim Justino, morador da região e um dos primeiros a explorar as cavernas junto com o grupo de franceses, conta que o nome Betari é muito antigo e, que examinou documentação datada da segunda metade do século XIX em que o denominativo Betari já aparecia com essa mesma grafia.

Betari é nome de um importante rio que atravessa o Petar. É um rio cristalino que nasce no alto da serra, corta a região de calcários ${ }^{67}$ e filitos $^{68}$,e deságua no rio Ribeira de Iguape, a montante da cidade de Iporanga. Está intimamente ligado à dinâmica do Parque, pois, além de participar da constituição física das cavernas e da paisagem local é um elemento importante das atividades de ecoturismo, tais como trilhas e boia cross. A estrada que liga Iporanga a Apiaí segue paralela às margens do Betari até

\footnotetext{
${ }^{67}$ Calcário, designação comum às rochas sedimentares (metamorfizadas ou não)constituída essencialmente por carbonato de cálcio e de magnésio, inclui as formas quase duras de carbonato de cálcio cristalizado (calcita, aragonita), as de teor mais elevado de carbonato de magnésio (dolmita), as de variável teor de impurezas(mármore, greda ou giz, etc); us. Como pedra de edificação, na produção de cal, como corretivo da acidez do solo, na fabricação de cimento, na refinação do açúcar etc. Dicionário Houaiss da língua portuguesa. Objetiva. Rio de Janeiro, 2007, p. 571.

${ }^{68}$ Filitos, rocha metamórfica, de estrutura cristalina ligada estruturalmente aos xistos argilosas. Dicionário Houaiss da língua portuguesa. Objetiva. Rio de Janeiro, 2007, p. 1343.
} 
o Bairro da Serra, passando pelo bairro Betari, que também fica a meio caminho entre o Parque e a cidade de Iporanga.

Betari é também o nome de uma reseva particular que abriga um Centro de Estudo da Biodiversidade (CEB), voltado para o estudo da fauna e da flora da Mata Atlântica. Possui infraestrutura para a pesquisa em ambientes controlados e está aberta à visitação.

Existe, entre os moradores do entorno do Petar, uma narrativa mítica que justifica o topônimo Betari. Contam que, faz muito tempo, vivia,na região, uma índia muito bonita, chamada Betari, que costumava se banhar no rio e quando o fazia era admirada por todos. Talvez a narrativa tenha origem na necessidade de se explicar um nome que é parte do conceito espacial dos moradores locais, mas para o qual não tenham encontrado um significado; criar a narrativa seria o mesmo que dar um sentido para aquele nome, um sentido metafórico. O percurso do Betari através do Petar comporta uma das mais belas paisagens do Parque. É nesse contexto que a narrativa se explica como uma metáfora conceitual dos moradores locais.

O vale, o bairro e a reserva estão localizados ao logo das margens do Betari portanto a motivação é o rio. No contexto do Bairro da Serra, o topônimo Betari está intimamente relacionado ao Petar e ao ecoturismo. Portanto, pode-se dizer que tal relação é conceitual, é a identificação e orientação que, segundo NorbergSchulz (1980), são os aspectos básicos para se apropriar do lugar, fazer parte dele.

O rio Betarizinho é um afluente do rio Betari. O sufixo diminutivo - inho, sugere essa ligação, nesse sentido a questão de ser um afluente do Betari está implícita no próprio nome. 
No presente levantamento, foram encontradas as formas, Bethary e Betary, não havendo alteração de sentido, optamos por manter a forma usada pelo parque que é Betari.

\section{Bocó}

Bocó: mocó > Mo-coó - bicho que rói, animal roedor

O rio do Bocó é afluente do Ribeira de Iguape, está localizado na região do quilombo de Ivaporunduva,e faz parte do ciclo do ouro do Alto Ribeira.

Hoje o rio Bocó está inserido no contexto do ecoturismo da região por sua beleza; é parte do roteiro da trilha do ouro que refaz o percurso dos primeiros exploradores até a capova ${ }^{69}$ de um morador antigo.

De acordo com a etimologia, bocó é um animal que se pressupôs seria encontrado com facilidade perto desse rio. Temos uma relação metonímica que denota a importância do animal no contexto da comunidade que denominou o rio. Como vimos a escolha de uma parte da paisagem para representar o todo demonstra relações significativas dessa população com o meio ambiente. A caça é um dado importante na vida de comunidades rurais. Se pensarmos nas comunidades indígenas, a importância só aumenta.

\section{Brejaúva}

Brejaúva: Ybyrayá-yba - a árvore de madeira rija. É uma palmeira de cuja madeira se serviam os índios para fazer os seus barcos.

Nome de ribeirão na região de Itaóca.

\footnotetext{
${ }^{69}$ Capoava (tupi) caá-poaba >é o abrigo na roça, cobertura de folhagem, obra de palha.
} 
Sabe-se que desde os tempos pré-históricos a ocupação do Alto Vale do Ribeira se deu pelos rios, estes eram os caminhos possíveis para se alcançar o sertão. O topônimo Brejaúva pressupõe que havia muitas brejaúvas em algum ponto do rio ou ao longo do rio. A relação metonímica da parte pelo todo denota a importância desse tipo de árvore para aquela população.

\section{Canhambora}

Canhambora : (tupi) caapora, caá- porá> o morador do mato, o matuto.

Existe a possibilidade da lexia ser originária do quimbundo: canhembora, quilombola, kilombo> acampamento fortificado, acampamento de escravos fugidios.

Nome de córrego e nome a uma Reserva Particular de Patrimônio Natural (RPPN) ${ }^{70}$. Essa reserva faz divisa com o Petar, anteriormente o local era área de extração de calcário. Está localizada no Bairro Soares, no vale do córrego Canhambora, afluente do Ribeirão Iporanga, distante aproximadamente $5 \mathrm{~km}$ da cidade de Iporanga. Essa Reserva ainda se encontra em processo de regularização.

O significado oficial de canhambora, segundo a Reserva é escravo fugidio.

Em nossa pesquisa encontramos além das duas acepções apresentadas acima, uma terceira possibilidade que seria uma

\footnotetext{
${ }^{70}$ A Reserva Particular do Patrimônio Natural é uma unidade de conservação particular criada por iniciativa do proprietário reconhecida pelo Instituto Estadual de Florestas(IEF). Não há exigência de tamanho mínimo nem máximo para a criação de uma RRPN, pois a criação depende apenas do desejo do proprietário. Disponível em http://www.ief.mg.gov.br/areas-protegidas/criacao-de-rppn, acessado em julho de 2013.
} 
combinação do tupi com o quimbundo justificando a acepção aceita pela reserva a de escravo fugidio.

Canhambora é o lugar onde mora o Sr. Arabelo; é assim que Canhambora é conhecido na região. Sr. Arabelo é morador antigo de Iporanga, talvez seja um dos únicos que ainda sabe comandar a dança de São Gonçalo na região do Petar.

Iguape (Ribeira do lguape)

Iguape: Yguá - pe - no lagamar, na baía fluvial.

Ribeira de Iguape é o nome do rio que forma a bacia hidrográfica do Ribeira de Iguape e banha todo o Vale do Ribeira.

Rio Ribeira de Iguape: topônimo híbrido composto de um nome português ( ribeira) e um nome tupi (Iguape).

$\mathrm{Na}$ composição do sintagma toponímico os dois elementos, Ribeira e Iguape pertencem ao mesmo campo semântico, seriam, portanto, co-hipônimos; o fato de o sentido da lexia Iguape, em tupi, não ser mais reconhecido inviabiliza a percepção de que os dois termos são semanticamente próximos. Outro ponto a ser considerado é a toponimização do termo ribeira que perde seu sentido original $^{71}$ e passa a nome próprio de lugar, referencializando o rio que denomina. Em razão dessa toponimização e consequente esvaziamento do sentindo original da lexia há a necessidade de se acrescentar o termo genérico rio ao sintagma toponímico.

Têm-se que os três componentes do sintagma toponímico pertencem ao mesmo campo semântico. Nesse sentido, rio pode ser considerado o termo hiperônimo pois mantém com os outros dois termos uma relação do todo pela parte.

71 Ribeira- 1. rio estreito e raso, riacho; 2.terreno às margens de um rio; 3. Alagadiço formado pelas águas de um rio ou mar. Disponível em http://aulete.uol.com.br/ acessado em julho de 2013. 
O rio Ribeira de Iguape como já explicitado anteriormente banha toda a região do Vale do Ribeira. Na região do Petar, o rio Ribeira de Iguape é um referencial muito forte, praticamente toda a comunidade do entorno se orienta por meio do fluxo desse rio. É comum ouvir dizer Ribeira acima e Ribeira abaixo ao indicarem um lugar ou se posicionarem em um ponto da região. O espaço, portanto, para a população do entorno do vale do Ribeira está conceitualizado segundo o fluxo do rio.

Dona Dita conta que nasceu em um local um pouco distante, Ribeira acima, chamado João Surrà (SILVEIRA, 2000, p. 170).

\section{Iporanga}

Iporanga: $y$-poranga $>$ y- água poranga - belo, formoso; rio bonito, formoso.

Iporanga é topônimo de origem tupi. Pressupõe-se que seja anterior à chegada dos exploradores europeus. É nome de ribeirão e nome de cidade.

De acordo com Houaiss ${ }^{72}$, ribeirão é curso de água maior que um regato e menor que um rio.

Do ponto de vista da cidade de Iporanga, local do encontro das águas do ribeirão lporanga com o rio Ribeira de Iguape, 0 ribeirão é mesmo menor que o rio. Mas sua importância na construção da história da cidade é maior que a do Ribeira. Nesse sentido, as relações significativas entre o acidente geográfico e a comunidade está explicitada no denominativo da cidade que adotou o nome do ribeirão.

No início de sua formação, a cidade foi conhecida como Freguesia de Sant'Ana de Iporanga. Assim como com Apiaí o

72 Dicionário Houaiss da Língua Portuguesa. Rio de Janeiro, 2007, 2oำ reimpressão com alterações, p.2456. 
denominativo reduziu--se a Iporanga. A justificativa de Dick de que a redução é consequência de uma simplificação ortográfica encontra novamente eco. A opção pelo topônimo de origem tupi e não o hierotopônimo reflete um processo de secularização do estado brasileiro que se deu por volta do Segundo Reinado e o advento da República.

No hidrotopônimo Iporanga há também uma sobreposição de significados em razão do y não ser mais reconhecido como água ou rio, sendo reconhecido como parte integrante da lexia. Devido à cristalização dessa forma, tornou-se necessário agregar o termo genérico rio.

Os gentílicos de Iporanga se autodenominam iporangueiros mais do que iporanguenses. Acredita-se que iporangueiro venha da mesma matriz de palmiteiro, mateiro, gruteiro, termos usados pelos moradores da região para identificar um saber fazer característico, quase como uma profissão ou uma habilidade específica. Portanto, ser iporagueiro pressupõe não só ter nascido em Iporanga, mas, mais do que isso, um ser e um fazer muito particular, um sentido voltado à territorialidade, iporangueiro seria orientação e identificação. Assim volta-se a Lakoff e Johnson e pode-se dizer que iporangueiro seria a incorporação de todos os conceptus do lugar transformado em uma identidade metafórica, isto é, ser de Iporanga significa ser mateiro, palmiteiro, gruteiro, balseiro e, atualmente, estar envolvido com a questão da preservação ambiental trazidas pelo Parque.

\section{Ivaporunduva}

Ivaporunduva - Ivaporundyba ou Voporundyva : rio de muito Vaporú, fruta. 
Nome de rio e de comunidade quilombola, situada no município de Eldorado.

Ivaporunduva é a comunidade quilombola mais antiga do Vale do Ribeira e a primeira a ter seu território reconhecido, como citado anteriormente $\mathrm{O}$ denominativo agrega semas além do descritivo de lugar, na região sua carga simbólica é muito forte, está associada ao movimento de luta por direitos territoriais. O sentido conceitual do topônimo para os moradores da região está relacionado às conquistas alcançadas e ao sentimento de auto afirmação das comunidades quilombolas.

Ivaporunduva representa um núcleo de referência para a formação de outros bairros negros localizados ás margens do rio Ribeira, nesse sentido, pode-se dizer que o topônimo já não referencializa somente um lugar, mas, também, o conceito de quilombo no Vale do Ribeira, conceito que agrega semas relacionados à resistência, luta e preservação da história.

\section{Nhungara / Anhanguara}

Nhunguara ( rio): Nhae- $u$ - o barro, quara- buraco (buraco de barro)

Nhum - o campo, o terreno limpo de seu natural, o prado com vegetação rasteira / Guara - sufixo que indica procedência, nacionalidade; o que vem do campo, o campeiro.

É nome de rio e de comunidade quilombola, situada na divisa dos municípios de Iporanga e Eldorado, era também uma região de antiga atividade mineradora. A ocupação do bairro se deu por meio dos afluentes do Ribeira do Iguape, esse processo de comunicação por meio dos rios era comum na região. 
Segundo a definição de Paulinho de Almeida ${ }^{73}$ Nhunguara, Nhanguara ou Anhanguara é buraco de barro. O nome teria sido atribuído a fim de "significar o pavor que concebiam dos estrondos frequentes das exhalações dos montes e lugares próximos, que se ouvem do Nhanguára" ( PAULINHO DE ALMEIDA, 1955).

Há a possibilidade de duas acepções baseadas em estudos de Teodoro Sampaio. A primeira coincide com o significado atribuído por Paulinho de Almeida que de acordo com Teodoro Sampaio $^{74}$ dever-se-ia procurar sempre a palavra primitiva, porque a palavra se compõe de elementos integrantes, cada um dos quais tem uma significação ou determina o todo. Nesse sentido, a acepção de Paulinho de Almeida pode estar baseada em formas primitivas que justifiquem o sentido do topônimo como buraco de barro.

A segunda acepção é uma possibilidade que também se explica no contexto espacial do topônimo: o que vem do campo caracterizaria os primeiros habitantes da região, indígenas, ou, os primeiros negros que ali chegaram. Sabemos que a região no entorno de Ivaporunduva foi a primeira a receber a população negra no Alto Ribeira já no final do século XVI e começo do XVII.

Padre Vieira, em 1694 escreveu: "É certo que as famílias dos portugueses e índios em São Paulo estão tão ligadas hoje umas com as outras que as mulheres e os filhos se criam mística e domesticamente, e a língua que nas ditas famílias se fala é a dos índios e a portuguesa a vão os meninos aprender, à escola." (Obras Várias, I, 249, apud Teodoro Sampaio, 1987, p. 70). Nesse

\footnotetext{
${ }^{73}$ Memória Histórica de Pariquera-Açu. 1939, Irmãos Oliveira, São Paulo. Apud, Negros do Ribeira : Reconhecimento Étnico e Conquista do Território. São Paulo, 2ed. - Cadernos ITESP 3, 2000, p.82.

${ }^{74}$ Teodoro Sampaio. O Tupi na Geografia Nacional. São Paulo. Companhia Editora Nacional, 1987, p. 59.
} 
contexto pode-se até mesmo sugerir que o topônimo é posterior à chegada dos europeus à região.

\section{Paranapanema}

Paranapanema: Paranã - pãnema - o caudal imprestável, impraticável.

Nome de importante rio que nasce na serra de Paranapiacaba à sudeste de São Paulo, em uma extensão de $930 \mathrm{~km}$ alcança o Paraná fazendo a divisa entre esses dois estados. Suas nascentes se encontram próximas ao Petar, em um cenário de mata Atlântica preservada.

É denominativo antigo, remanescente de populações indígenas. A etimologia descreve a relação que essa população mantinha com o rio. Um rio que não se prestava á navegação devido a suas condições naturais, bancos de areia, rochas, pouca profundidade, trechos com forte declividade etc. Nesse sentido o processo metonímico denota a relação dessa comunidade com os grande fluxos de água. Poderia tratar-se de uma comunidade canoeira que usava os rios como meio de locomoção.

A importância do resgate das etimologias nos ajudam a revelar aspectos importantes dessas populações que são parte integrante de nossa cultura.

O sentido original do denominativo se perdeu, como ocorreu com a maioria dos nomes de origem indígena, portanto as relações significativas são outras, o topônimo Paranapanema hoje está mais relacionado à sua situação geográfica como divisor do estado de São Paulo e Paraná e por concentrar importantes hidrelétricas que abastecem a região.

\section{Paranapiacaba}


Paranapiacaba: Paranã - apiacaba - a vista do mar, o ponto donde se pode avistar o mar, miramar.

A serra de Paranapiacaba é parte da Serra do Mar e está localizada à sudeste do Estado de São Paulo próximo à fronteira entre São Paulo e Paraná. Ela se insere entre as bacias do rio Paranapanema e Ribeira de Iguape.

O continuum ecológico de Paranapiacaba que faz parte do Sítio do Patrimônio Mundial Reservas do Sudeste compreende os parques Estaduais do Petar, Intervales e Carlos Botelho, Com uma área de aproximadamente 120.000 ha. Representa o maior conjunto de Mata Atlântica do Brasil. A região do Alto Ribeira está inserida no contexto espacial da serra de Paranapiacaba.

No entorno do Petar a serra de Paranapiacaba foi segmentada em serras menores que estruturam o espaço local. Cada porção de serra foi denominada levando em conta as relações significativas que a comunidade mantinha com ao lugar.Como diz Norberg-Schulz (1980) o lugar só adquire significado quando nos identificamos e nos orientamos nele. Nesse sentido entende-se a segmentação e denominação da serra de Parapiacaba como uma apropriação do espaço tornando-o lugar.

A etimologia de paranapiacaba traduz com precisão a situação geográfica dessa parte da Serra do Mar em que são encontradas as maiores altitudes da região do Paraná.

\section{Temimina}

Temimina : Temiminó - o neto da parte do varão, nome de uma nação do gentio do Espírito Santo e do Rio de Janeiro.

Nome de rio, nome de duas cavernas (Temimina I e Temimina II ) e nome da Base Temimina ( ponto de fiscalização), todos situados ao norte do Petar, no núcleo Caboclos. 
Temimina é topônimo tupi. Nome de uma etnia indígena, os Temiminós. Os temiminós ou temininós foram uma tribo de língua tupi que habitava, principalmente, o litoral da região sudeste brasileira no século XVI. Era inimiga habitual dos tupinambás, mas possuía muitos traços culturais em comum com estes e com outras tribos tupis, tais como a língua semelhante, crenças, costumes como o canibalismo ritual e a agricultura de subsistência baseada em queimadas ${ }^{75}$.

$\mathrm{Na}$ atual pesquisa, encontrou-se referências à existência de grupos tupis na região do rio Paranapanema, portanto, próximo à região do Petar, chamados Parana. Estes seriam, talvez, posteriormente, chamados de Temiminós, "a gente (Carijó) é lavradora e tem língua geral dessa província (...) Por aqui é certa também a entrada para o Iguaçu, onde há grande número de gente, ainda que, como contam bem belicosa, dos os Paraná, compram índios cativos de outras nações e os trazem as suas terras e os matam com grandes bebedeiras, dando-Ihes novos nomes por ter matado" (1613. In: Duarte et L. 1978,p52, apud Prezia, 2010,p.167).

Ainda sobre a existência dos temiminós na região do Petar, Monteiro discorre sobre a necessidade dos paulistas irem buscar mais longe a mão escrava índia, como os Temiminó de Paranapanema e sobretudo os Guarani. (Monteiro, 1992,p.490 apud Prezia, 2010,p.203)

Acredita-se que o topônimo possa ser indicativo da presença desse grupo na região.

Segundo Levy Cardoso (1961), é comum encontrar-se topônimos que se originaram das denominações das próprias

\footnotetext{
${ }^{75}$ Disponível em http://www.cnecri.com.br/ojs/index.php/temiminos/about/history, acessado em 25 de julho de 2013.
} 
tribos. Como exemplo, cita o nome do estado de Goiás, que teria sua origem na denominação dos "antigos silvícolas Goiá".

\section{Xiririca}

Xiririca: Y-chiririca - água ligeira, veloz, a corredeira.

Nome de rio, ribeirão Xiririca, situado próximo à cidade de Eldorado e antigo nome da cidade de Eldorado.

Xiririca foi nome de aldeia indígena. Contam que a povoação se formou no século XVI no local onde havia uma aldeia indígena. É presumível que o denominativo seja anterior à chegada dos europeus. Xiririca é também nome de rio, ribeirão Xiririca.

Em 1948, o município de Xiririca passou a ser denominado Eldorado. Tal mudança se deu pelo desconforto que o topônimo Xiririca causava na população. Essa mudança de nomes denota aspectos importantes da relação do homem com o meio ambiente. Enquanto o denominativo Xiririca referencializa um aspecto da natureza que denota o íntimo convívio do indígena com o ambiente à sua volta; quem sabe um indicativo de que naquele ponto haveria que se cuidar, pois a transposição pelo rio seria difícil. $O$ topônimo Eldorado revela uma relação mais material, e até mítica com o ambiente, a exploração do ouro, referindo-se à riqueza mineral que atraiu os primeiros povoadores, em uma alusão à lenda do Eldorado", o país imaginário da América do Sul, procurado por inúmeros exploradores europeus após descobrimento. Fica clara uma mudança de perspectiva em relação ao território. Enquanto o indígena valorizava sua relação com o meio natural, o europeu via a natureza como um meio para alcançar seus objetivos materiais. Essa perspectiva predomina até hoje. As Unidades de Conservação colocam a questão em destaque: até que ponto podese fazer uso dos recursos naturais sem inviabilizar a vida das 
próximas gerações e como sobreviver em um ambiente com restrições severas de uso da terra?

A mudança de nomenclatura reflete os conflitos que enfrentam as comunidades do Alto Ribeira vivendo em uma região em que $60 \%$ do território sofre algum tipo de restrição em favor da conservação da Mata Atlântica do Estado de São Paulo.

Há, na região do Petar, um número significativo de denominativos, em especial de fluxos d'água, de origem tupi, esses nomes configuram em sua maioria a contribuição das línguas indígenas na formação do português do Brasil. Predominam os zootopônimos, Tatu, Jacú, Pacas, Jaguatirica Tatu, e os fitotopônimos, Xaxim Taquari, Taquaruvira, Samambaia. A motivação está em consonância com o padrão de ocupação da região, pois se trata de uma população que vive em contato íntimo com a natureza.

Pode-se considerar que esses nomes não correspondam à primeira fase de ocupação da região, ou seja, a ocupação indígena; eles podem inclusive corresponder à última fase, quando o Parque foi implantado, no início dos anos de 1980; este seria o caso do nome de caverna Jararacuçu, motivado pela presença de uma cobra jararacuçu na entrada da gruta.

Porém, considera-se a origem da lexia e os traços culturais embutidos nela. O topônimo Paçoca, nome de córrego e gruta, explicita de forma bastante clara a contribuição dos povos indígenas na construção da identidade cultural brasileira.

Paçoca - Po-çoca, é gerúndio supino de poçoc, que é esmigalhar, desfiar, esfarinhar.

Paçoca é, pois, o desfiado, o esmigalhado. Alimento preparado com carne assada e farinha, piladas conjuntamente constituindo 
uma espécie de conserva, muito própria para viagens do sertão.

Era o farnel dos bandeirantes. (Sampaio, 1987,p.298)

Vê-se que além do vocabulário, paçoca revela uma atividade muito comum na região do vale do Ribeira, em especial nas comunidades quilombolas. É comum haver um pilão na maioria das residências e é bem comum esse pilão ainda ser usado para pilar farinha e carne assada, prática que se pressupõe adquirida das comunidades indígenas.

\subsubsection{Miscigenação étnica do Alto Ribeira}

A segunda camada remete à ocupação do espaço pelo homem europeu. A chegada do europeu para explorar o ouro na região configura a primeira fase dessa ocupação. Como visto na descrição da historiografia da região do Alto Ribeira, já no século $\mathrm{XVI}$, há dados que confirmam o contato do europeu com os indígenas que habitavam o lugar. $\mathrm{O}$ ato denominativo denota essa ocupação e a apropriação do espaço que não estava vazio e pressupõe-se já denominado pelos antigos habitantes. Há, portanto, uma nova estruturação do espaço.

Um dos traços mais característico dessa fase são os nomes com motivação religiosa, os nomes de santos e, em especial, as diversas versões do nome de Nossa Senhora, referencializando os lugares. O nome da lavra de ouro à beira do ribeirão Iporanga onde foi erguida a primeira capela, que deu origem ao município de Iporanga, chamava-se Arraial de Santo Antonio.

A chegada dos negros à região para trabalhar nos garimpos marca outra etapa dessa camada denominativa. No entanto, essa população não deixou traços típicos de línguas africanas na toponímia como se poderia pressupor. 
O Vale do Ribeira caracteriza-se por concentrar o maior número de comunidades quilombolas do estado de São Paulo, contudo, a toponímia da região não reflete traços da cultura africana. Neste corpus encontra-se dois denominativos que podem ser originários de línguas africanas, Caximba e Canhambora. Dados como a antiguidade da chegada do negro à região, a formação de grupos familiares e a interação com as comunidades já instaladas na área, em especial os indígenas, mostram uma miscigenação étnica na qual traços do continente africano quase desapareceram.

Com isso não se quer negar o passado escravista dessa comunidade. Portanto, a marca peculiar dessa população é, sim, uma miscigenação cultural com a comunidade local. Esse dado configura uma das maiores riquezas da região, sua diversidade étnica e cultural. Outro aspecto importante dessa fase, explícita na toponímia, é justamente essa miscigenação étnica e cultural. Os moradores antigos, chefes de famílias, deixaram suas marcas na toponímia local. Encontra-se um grande número de antropônimos no entorno do Petar, tanto nos acidentes físicos quanto nos acidentes culturais. Esses nomes de pessoas referencializam lugares que tais famílias ocuparam ou ocupam até hoje. Na região de Itaóca, vizinha a Iporanga, há uma comunidade quilombola de nome Cangume. Contam que, nos anos de 1870, um negro escravo, João Cangume, um dos primeiros negros que fugiram para Pinheiro Alto, habitou o local, que depois passou a ser chamado de Cangume.

André Lopes, nome de comunidade quilombola próxima à Ivaporunduva, no município de Eldorado, também tem seu nome vinculado a uma lenda "segundo a qual aí teria naufragado o sargento mor da Ilha de São Sebastião André Lopes de Azevedo, 
casado com D. Maria Francisca e falecido na Freguesia de Xiririca, onde residia aos 15 de junho de 1764, na avançada idade de cem anos" (Paulinho de Almeida, 1955) ${ }^{76}$. Como esses, tem-se no corpus um grande número de antropônimos que registram uma territorialidade marcada pela centralidade do homem sobre a natureza. Percebe-se que as relações mudaram e estão refletidas no ato de nomear.

Os nomes de lugar dessa segunda camada já não expressam a interação homem/natureza que havia antes da conquista europeia do continente americano. Em tese, o conquistador chegou e dominou um espaço que pertencia àquele que detivesse maior poder. A natureza é vista como fonte de riquezas e deve ser utilizada em todas as suas possibilidades.

$\mathrm{Na}$ região do Alto Ribeira, essa relação apresenta características específicas, pois o "conquistador", aquele que chegou para dominar, era, na verdade, em sua maior parte, pertencente a uma população que também estava sendo explorada: os negros africanos. Nesse sentido, entender que o processo denominativo explicitado por nome de pessoas conota o domínio dessa comunidade sobre o espaço ocupado não reflete a realidade do Vale do Ribeira. Na ocupação do entorno do Alto Vale, as territorialidades se caracterizam por pequenos grupos familiares em bairros rurais que se apropriaram do espaço de forma pouco predatória; ao visitar o Petar e encontrar uma área significativa de floresta primária ${ }^{77}$ essa realidade pode ser confirmada.

\footnotetext{
${ }^{76}$ PAULINHO de ALMEIDA, A. Memória Histórica de Xiririca (EI Dorado Paulista) IN Boletim Volume 14, 1955. Apud Negros do Ribeira : reconhecimento étnico e conquista do território - 2edição - São Paulo: ITESP: Páginas e Letras -Editora Gráfica 2000, p.82.

77 Vegetação primária: aquela de máxima expressão local com grande diversidade biológica. Sendo os efeitos das ações antrópicas mínimos ou ausentes a ponto de não afetar significamente suas características originais de estrutura e espécies. Disponível em:
} 
$\mathrm{O}$ ato denominativo dessa população reflete mais uma interação entre homem e meio ambiente do que uma ruptura.

As comunidades do Vale do Ribeira se apropriaram de práticas dos povos indígenas, a roça de coivara é o exemplo mais expressivo dessa apropriação, mas, ao mesmo tempo, se mantiveram integradas à sociedade vigente. É nesse contexto entre uma população com uma relação conectada à natureza, a indígena, e outra que tem a natureza como fonte de enriquecimento que se desenvolveu a sociedade do Alto Vale. Depara-se com a preservação e relação harmoniosa com a natureza e, ao mesmo tempo, vê-se essa comunidade participando de práticas predatórias como o extrativismo vegetal e mineral.

Essa situação reflete-se nos denominativos de locais como vistos; nomes próprios de pessoas denominando a paisagem, rios, serras, bairros, antropônimos de quem se tornou parte constitutiva do território, isto é, trabalhadores, pequenos agricultores, os quais, com suas próprias mãos, tiravam seu sustento da terra. Encontrase na atual pesquisa, lugares dentro do Petar com nomes como Buenos, onde residia o Sr. Manoel Bueno, Serra dos Mottas, como visto anteriormente, nome da primeira família a ocupar o bairro da Serra, e cujos descendentes vivem no local ainda hoje.

Os signos do cristianismo trazidos pelos europeus deixam de ser o principal motivo do ato denominativo e o homem, aquele que trabalha a terra com suas próprias mãos, passa a ser a principal motivação do ato denominativo. Estes antropônimos têm a função de delimitar o território, a posse se dá pelo nome do patriarca, daquele que primeiro se estabeleceu no lugar. Sabe-se que na

Disponível em http://www.ipaam.br/legislacao/RESOLUCÕES\%20CONAMA/2007/resolução\%2 0conama\%20n. $020392, \% 20$ de\%2025.06.07\%20(definição\%20de\%20vegetaçã 0\%20primária\%20e\%20secundária\%20de\%20regeneração\%. Acessado em 26 de junho de 2013. 
região do Vale do Ribeira os grupos familiares, de parentesco são a base da organização dos bairros rurais.

\section{Os bairros rurais:}

Silveira (2001,p.84) define o sentido de bairro para os moradores do Alto Ribeira:

O que é o bairro? perguntei certa vez a um velho caipira, cuja resposta pronta exime numa frase o que vem exposto aqui: Bairro é uma naçãozinha. - Entendase a porção de terra a que os moradores tem consciência de pertencer, formando certa unidade diferente das outras.

O traço distintivo da ocupação do Alto Vale do Ribeira referente a essa camada está configurado pelos criação dos bairros rurais. Esses bairros caracterizam-se pelos laços de parentesco que os une e pelo sentimento de pertencer ao lugar, não há limites definidos demarcando esses territórios.

De acordo com Lino (1978) fatores baseados na ordem econômica e social favoreceram o aparecimento dos bairros.

A ocupação da região se deu com a chegada de garimpeiros em busca de ouro no século XVI. Junto com eles vieram as primeiras famílias dando origem aos arraiais.

Os afluentes do Ribeira foram os caminhos para se conquistar o sertão serra acima; ao longo dessas ramificações foram surgindo bairros como Ivaporunduva, Nhunguara, Arraial de Santo Antonio.

Os bairros surgiam a partir de roças de domínio familiar. Baseadas na agricultura de subsistência essas comunidades mantinham um relativo isolamento em relação aos outros bairros. $A$ prática das roças de coivara exigia grandes áreas para o cultivo de suas plantações, cada família do bairro possuía sua roça, ou seu sítio, distante de um a dois quilômetros um do outro ou até mais 
que isso. Com o crescimento das famílias, os casamentos entre pessoas de bairros diferentes surgiam novos bairros.

Esse modelo de ocupação a partir de grupos familiares é predominante na região e tem como um dos traços mais marcantes a sua denominação identificada com a família que deu origem ao bairro: Serra dos Mottas, Camargos de Cima, Buenos, Maximiliano, bairro dos Rochas, Martinho, Morro da Joana.

A ocupação espacial na maioria das vezes é feita de forma aleatória pela área, ficando difícil definir qualquer centro, há casos em que é difícil até perceber à primeira vista a existência do bairro pela rarefação das construções e pela vegetação fechada que cerca as moradias (LINO, 1978).

O perímetro desses bairro não é definido fisicamente "mas sim por um sentimento de localidade" (LINO,1978,p.47). Pode-se dizer que esse sentimento de localidade seria mais do que uma localização abstrata. De acordo com Norberg-Schulz (1980), o lugar é uma totalidade composta de coisas concretas tendo substância material, forma, textura, cor. Juntas, determinam um caráter ambiental que é a essência do lugar, a concreta manifestação do habitar. O lugar é entendido como tendo um interior e uma superfície, nesse sentido podemos dizer que esse sentimento de localidade seria uma conceitualização do espaço como recipiente (LAKOFF \& JOHNSON, 1980).

Há os bairros que se originaram em função de passagem e pouso. Primeiro aqueles estabelecidos ao longo do vale do Betari: Serra dos Motta, Passagem do Meio, bairro Betari, começaram como bairros familiares, mas devem seu desenvolvimento à passagem de tropas pela trilha que ligava Iporanga a Apiaí.

Outros bairros tiveram sua origem em função das rotas fluviais em especial as do Ribeira do Iguape e seus afluentes mais 
caudalosos. As canoas entraram no lugar das tropas e os pontos de entroncamento das trilhas passaram a ser as barras dos ribeirões no rio principal, nesses entroncamentos de rios formaramse diversos bairros rurais. Barra de Iporanga, Barra do Batatal, Barra do Turvo (no rio Pardo), Barra do Braço (rio Batatal), Barra dos Pilões ( rio Ribeira) (LINO, 1978).

De acordo com o dicionário Aulete ${ }^{78}$ :

Barra é banco ou coroa de areia e outros sedimentos que os rios trazem e depositam no local em que desembocam, ou, é entrada de baía; embocadura.

O termo barra adicionado ao nome do rio compondo o sintagma toponímico configura um referente geográfico, ao se tornar nome de lugar temos a toponimização do acidente geográfico.

Esses bairros se originaram de sede de posses que instalavam nesses ancoradouros depósitos de cereais, alambiques, indústria de beneficiamento (de arroz, café etc.) e uma venda. Eram fazendas de um só proprietário ou centros comerciais coletivos que pela localização estratégica se transformavam em centro de troca de informação, em estação de transporte e baldeação, em centro de atividades sociais (escola, festas, romarias) e o principal, em centro de referência na área circundante, ponto de parada para os viajantes e pesquisadores que visitavam a região (LINO, 1978).

Com a abertura das estradas e o rio deixando de ser usado como via de transporte em pouco tempo a maioria desses bairros desapareceu. A interligação das cidades feita por via terrestre era muito mais vantajosa para os moradores da região. Somente aqueles bairros localizados em pontos estratégicos sobreviveram e até se desenvolveram.

${ }^{78}$ Disponível em : http://aulete.uol.com.br/. Acessado em agosto 2013. 
Interesses de grupos externos relacionados com a exploração de minérios e grandes fazendas monocultoras ou madeireiras originaram bairros rurais em desacordo com o padrão local de ocupação. Nesses bairros a disposição espacial das moradias, a posse pela terra e a organização do trabalho diferem muito daquelas dos bairros tradicionais. Os laços de parentesco e compadrio deixam de ser fatores de organização dos bairros, as relações sociais se baseiam na divisão do trabalho voltada para um único ou alguns poucos produtos a serviço de um patrão comum. Em tal modelo, não existe mais uma estrutura social e econômica igualitária, onde cada um decide sobre sua produção e onde o trabalho coletivo se faz como troca de favores, oportunidade de relacionamento ou auto defesa (LINO, 1978).

O uso da terra está condicionado ao trabalho que executa, se perde o emprego, não tem mais direito à moradia, é obrigado a deixar o bairro, a escola de seus filhos, a pequena horta cultivada no entorno de sua casa, a criação de animais domésticos.

Se, por um lado, adquirem uma razoável segurança e estabilidade financeira em razão do salário mensal ou quinzenal, de outro ficam dependente do bom andamento dos negócios da empresa ou da fazenda.

Nesse contexto, a configuração do espaço muda radicalmente. As casas são padronizadas, o assentamento é planejado de acordo com traçados geométricos cuja regularidade contradiz as formas espontâneas de assentamentos das moradias e organização espacial dos bairros tradicionais (LINO, 1978).

Esses bairros são denominados com 0 nome das mineradoras, ou das fazendas, nesse sentido a relação dos moradores com o lugar está refletida no denominativo, relação está 
baseada na hierarquia profissional e econômica: Furnas, Lageado e Espírito Santo, como nome de mineradoras.

Apesar de o aspecto metonímico implícito nos denominativos Furnas e Lageado, estabelecer relações de contiguidade com o lugar essa relação deixa de ser significativa, pois para a comunidade local os denominativos referencializam as empresas mineradoras, que geraram emprego e mudaram a relação de parte da população com o espaço. Ainda hoje, apesar de não ter restado nenhuma mineradora em funcionamento na região, e os bairros terem sido abandonados, para a população local os denominativos, Furnas, Lageado e Espírito Santo significam nomes de empresas mineradoras, já para o turista ou aqueles que não fazem parte da comunidade do entorno do Parque, esses topônimos referencializam grutas, córregos, trilhas, portanto são nomes de grutas, nomes de córregos e nomes de trilhas; o sentido do denominativo muda de acordo com o ponto de vista de quem ocupa o lugar ${ }^{79}$.

As grandes fazendas também desapareceram da região em função das restrições de uso da terra, tais como a fazenda Caximba, em Apiaí, a fazenda Caiacanga, em Eldorado e fazenda Santana em Iporanga. Os bairros que surgiram das regiões outrora ocupadas por essas fazendas não conservaram nenhuma característica que os identificasse a elas.

\section{Caboclos:}

Caboclos é nome de serra, bairro e núcleo de visitação do Petar. Todos localizados dentro do Parque.

De fato, a principal característica apontada por vários autores como definidora de uma cultura cabocla é a

\footnotetext{
${ }^{79}$ Ocupar é usado no sentido amplo de estar no lugar e, não necessariamente, também morar no lugar.
} 
presença integrada de traços portugueses e indígenas" $\left(\right.$ GALVÃO, 1955, p.58) ${ }^{80}$.

De acordo com a história de ocupação do Alto Vale do Ribeira sabe-se que na região conviviam índios, brancos, e negros. A miscigenação étnica pode ser confirmada pelo depoimento de moradores que afirmam serem tataranetos ou bisnetos de índios. "A presença indígena era muito forte na região e os conflitos com os índios muito comuns [...] alguns moradores afirmam que sua bisavó era índia sendo pega a laço" (ITESP, 2002, p.38) ${ }^{81}$.

Umas das acepções proposta por Caldas Aulete é a de que caboclo é pessoa do campo, de modo simples e rústico, caipira.

$\mathrm{Na}$ pesquisa de campo, conversou-se com o Senhor Alberto Corrêa, descendente dos primeiros moradores do bairro Caboclos, que relatou a história da formação do bairro desde seus primórdios.

Conta que Salvador Henriques abriu posse das terras no ano de 1831, segundo consta em escritura lavrada pelo padre Bernardo de Moura Prado. Mandou o filho, Hilário, para o extremo da propriedade, a um lugar conhecido pelo nome de Sertão. Com a morte de Salvador Henriques, sua esposa, Dona Maria Luiza, conhecida por Maria Ourives, pois tinha grande habilidade na arte de trabalhar com ouro, mandou o filho, José Henriques Correa, com apenas nove anos, morar com o irmão no Sertão. A área ao lado dessa posse era ocupada por Benedito Henriques, filho natural de Salvador com uma escrava de Apiaí. Benedito era livre, sua liberdade fora comprada por seu pai. Benedito morreu só e contam que tinha muito ouro enterrado em sua propriedade, mas ao ser

\footnotetext{
${ }^{80}$ GALVÃO, Eduardo. Santos e Viagens: Um estudo da vida religiosa de Itá. São Paulo. Cia Editora nacional, 1955.

${ }^{81}$ Relatório Técnico Científico sobre os Remanescentes da Comunidade de Quilombo de Praia Grande/ Iporanga-SP.
} 
indagado no leito de morte sobre o tesouro dizia: A terra deu a terra leva.

José Henriques Correa, bisavô de Alberto, conhecido por Juca Caboclo, pois se referia às pessoas chamando-as de Caboclo, construiu em sua casa uma pousada de tropeiros. A família passou a ser conhecida como Caboclos e o bairro passou a ser identificado como bairro da família Caboclos.

De acordo com o presente levantamento, nessa camada denominativa há um número significativo de antropotopônimos que revela o domínio de grupos familiares ou com ligação de parentesco na constituição dos bairros rurais.

A mudança do nome Sertão para Caboclos, pode ser indicativa da transformação do lugar, antes conhecido apenas como rota de tropeiros, lugar ainda selvagem, transformado em um lugar de abrigo, em virtude da pousada instalada pela família Caboclos. Nota-se que a representação anterior do lugar era quase um não lugar, o sertão, a mudança no denominativo representa a apropriação e significação do lugar pelo homem que passa a ser seu referente, o lugar da família Caboclos. A apropriação do lugar é tão significativa que a serra, local onde a família Caboclos morava passa a ser denominada Serra dos Caboclos. O não lugar, 0 sertão, signo não marcado passa a signo marcado com a mudança do denominativo, Caboclos sinalizando a apropriação e 0 consequente recorte do espaço tornando-o lugar.

Com a implantação do Parque nos anos de 1980, foi construído um núcleo de visitação na região do bairro Caboclos, denominado núcleo Caboclos. As restrições imposta pelo parque, fizeram com que o bairro praticamente deixasse de existir como local de moradia, acredita-se que haja uma única pessoa morando na região. 
Dentro desse contexto, há uma mudança de sentido do denominativo Caboclos, os semas referentes à ocupação humana tais como, pousada de tropeiros, lugar onde vive a família Caboclos, bairro com casas e pessoas etc., deixam de ser significativos para os mais jovens e aqueles que não participam das comunidades da região do Parque, uma nova configuração semêmica é constituída, agora agregando os traços semânticos relativos ao Parque como, preservação da natureza, ecoturismo, lugar de belas cavernas e cachoeiras, núcleo turístico etc.

Essa mudança de sentido no denominativo reflete as mudanças que estão acontecendo com toda a população do entorno do Parque. Os traços representativos das relações entre a população e o lugar mudaram. Já não se entende o espaço como o lugar do sítio ou da roça dos moradores locais. As posses que puderam ser legalizadas e, os moradores com isso conseguiram a titulação de sua posse, se tornaram proprietários de terrenos com valor de mercado. A relação homem /lugar mudou. Assim como as relações significativas do topônimo.

\section{Praia Grande}

Praia Grande é uma comunidade quilombola localizada a sudoeste do município de Iporanga na divisa com o estado do Paraná.

A comunidade de Praia Grande era composta pelos bairros de Praia Grande e João Surá. De acordo com os moradores mais antigos, havia relações de parentesco entre as duas comunidades, portanto consideravam-se um único grupo. A divisão se deu em consequência do processo de reconhecimento como comunidades remanescentes de quilombo, essas duas comunidades estão 
situadas em estados diferentes do território nacional e, portanto, tiveram processos separados.

O bairro de Praia Grande, como todos os outros bairros rurais da região, subdivide-se em pequenas localidades, ou sítios, estes sítios foram nomeados pela população de acordo com as características do local ou com o nome do morador, são eles: Aberta, Martinho, Praia Grande, Bofe de Paca, Poço Grande, Amoras. São denominativos muito antigos, aparecem no livro de registro de terras do ano de 1855. (SANTOS, 2002).

Localizado às margens do rio Ribeira de Iguape o nome da comunidade, relaciona-se às praias de areia branca que se formam ao longo do Ribeira, a maior e a mais bonita delas é a que fica na frente ao bairro, a Praia Grande.

É uma comunidade antiga, presume-se que exista há mais de 140 anos.

Antônio Carlos de Andrade Pereira de 42 anos, morador do bairro João Surá, conta como se deu a ocupação desses bairros:

Antes.... era Sertão do Rio Pardo. Porque Sertão do Rio Pardo? Quando os escravos..., aqueles que trabalhavam na garimpagem de ouro no Vale do Ribeira, eles foram subindo pra cá, e uns deles se refugiando, acompanhando, se escondendo pra cá. De Praia Grande pra cá, era onde os escravos se refugiavam, João Surá, esses lados pra cá. Fugiam dos senhores. Os senhores não tinham condições de buscar os escravos, por que a cachoeira era muito ruim de subir. Para eles virem de Xiririca aqui demorava 12 dias para vir e voltar: Não tinha condições de entrar no mato, era muito ruim de andar, era muito morro. Eles não tinham condições de procurar, por que era sertão mesmo. Depois de passado um tempo... a história de João Surá 
o livro Tombo não conta. A gente sabe a história de João Surá aqui, no local ${ }^{82}$.

$\mathrm{Na}$ região chamada Martinho existia um cemitério muito antigo, contam que ali eram enterradas as pessoas que morriam em conflito com indígenas e também os índios.

A comunidade de Praia Grande produzia arroz, milho, mandioca, cana de açúcar e frutas como jabuticaba, banana e abacaxi. Tinham engenho e produziam rapadura e açúcar. Criavam pequenos animais para consumo doméstico. De 1920 a 1940 deuse o apogeu do desenvolvimento da comunidade devido ao crescimento demográfico e à comercialização de seus produtos com as cidades de Iporanga e Apiaí. Nessa época, os moradores diziam que Praia Grande era maior que Iporanga.

Desde os anos de 1990, a comunidade se sente ameaçada pela construção da Usina Hidrelétrica de Tijuco Alto que inundaria quase todo o território de Praia Grande.

Atualmente, o único acesso à comunidade é feito por canoa. $A$ escola deixou de funcionar e as crianças precisam descer o rio de barco até o bairro de Descalvado, passando por um trecho perigoso com muitas corredeiras, para então pegar o transporte escolar para Iporanga. Esse isolamento provocou o esvaziamento do bairro. Há poucas famílias morando atualmente em Praia Grande. Os poucos que restaram praticam agricultura de subsistência. Um dado importante é a preocupação da comunidade com a conservação ambiental. $\mathrm{O}$ desmatamento feito por propriedades particulares

\footnotetext{
${ }^{82}$ Associação dos Remanescentes de Quilombos do Bairro de João Surá, Nova cartografia social dos povos e comunidades tradicionais do Brasil. Adrianópolis,Paraná, 2009. Disponível em http://www.novacartografiasocial.com/downloads/Fasciculos/qs 01 joao\%20sura .pdf, acessado em 03 de julho 2013.
} 
vizinhas, desrespeitando as normas ambientais vigentes, incomoda aos moradores.

O denominativo Praia Grande está associado diretamente ao rio Ribeira de Iguape. A conceitualização do espaço na região se dá em função do rio. As praias ao longo do Ribeira são conhecidas e denominadas. Para quem não compartilha do cotidiano do entorno do Petar, a percepção de que o topônimo referencializa uma praia do rio pode passar despercebida, pois para essa população a lexia praia é parte do campo semântico de mar. Portanto, deve-se buscar o sentido do topônimo no contexto de uso, isto é, no lugar.

A importância dos bairros rurais na região agrega ao topônimo semas que remetem ao lugar e a seus moradores, em especial aos moradores mais antigos que eram os que organizavam os puxirões e as festas religiosas, muito significativas na região e na comunidade de Praia Grande.

\section{Antropônimos}

A predominância dos antropotopônimos nessa camada denominativa pode ser verificada na análise quantitativa apresentada em gráfico acima. Há um número elevado de nome de pessoas não só denominando acidentes humanos como também acidentes físicos, rios, córregos, serras etc. No corpus desse trabalho essa é uma das taxes mais numerosas ficando atrás apenas dos zootopônimos. Motivações relacionadas às plantas (fitotopônimos), à água (hidrotopônimos) ou às formações geográficas (geomorfotopônimos) consideradas fundamentais em um ambiente de montanhas, serras, rios, cachoeiras e florestas apareceram em menor número que os referentes aos nomes de pessoas. 
A ocupação do Alto Vale do Ribeira se deu de forma espaçada, os bairros rurais se configuravam distantes um dos outros refletindo um pouco da história de ocupação do lugar como já foi visto. Nesse sentido, se por um lado os antropônimos tinham o papel de dar legitimidade à posse do território, em uma região em que as propriedades eram reconhecidas pelos vizinhos e os limites demarcados "pelo sentimento de localidade" (LINO 1978), por outro, esses nomes funcionavam como dêiticos referencializando localidades, neste caso nem sempre se conhecia a história da pessoa e se de fato ela existiu no contexto do lugar.

Há casos em que moradores antigos de um bairro ou sítio acabavam por agregar ao seu nome o denominativo do lugar ou até mesmo serem reconhecidos por esse nome. Com o passar do tempo e a perda da memória da gênesis do nome do lugar atribuíase as esses moradores a causa motivadora do topônimo. Taluá, que compõe o corpus desse trabalho pode ser um desses casos. Em Iporanga encontramos pessoas que afirmam que existia um cidadão de nome de Taluá, acreditam que o topônimo Taluá seja em função do nome dessa pessoa, portanto, um antropônimo. Há, porém, outros, que afirmam que o bairro é bem antigo, antecede ao morador. Assim, Taluá pode ser uma lexia de origem tupi, tauá (tagua), que quer dizer barreiro, significado que tem muito sentido no contexto do lugar, nesse sentido teríamos um litotopônimo.

Existe no entorno de Iporanga, próximo ao ribeirão Iporanga, um bairro e um córrego denominado Tudo. Encontrou-se esse denominativo grafado em mapas, inclusive no mapa do IBGE, como Tude. Para os moradores locais o nome do bairro e do córrego é Tudo. Sr. Gervásio, nascido no bairro e morador antigo do local nos informou que o bairro sempre teve esse nome e que desconhece a razão de sua origem. Pode-se supor que haja aqui um movimento 
inverso ao descrito acima. Tude seria um antropônimo que pela estranheza que esse nome causava aos moradores locais acabou sendo confundido com Tudo, pela semelhança fonética e pelos traços semânticos de tudo que era parte do universo lexical dos moradores locais. Outro ponto a ser considerado seria a falta de referentes que justificasse o nome Tude. De acordo com a abordagem de Lakoff e Johnson (1980), não se encontrou referentes significativos (metáforas/metonímias) que pudessem ser representativos desse nome e dar sentido à lexia, significando-a para a população local.

Mottas, Camargos, Buenos, Caboclos, Maximiniano, são exemplos de moradores locais que deram seus nomes aos locais onde viviam e do qual ainda se tem informação de quem foram e, até, de onde vieram.

De acordo com Dauzart (1922) os nomes de rios e serras são os mais antigos, aqueles que se perpetuam por mais tempo. Encontrou-se, no entorno do Petar, topônimos de serras e rios com nome de pessoas, acredita-se que pode ter havido um processo de renomeação, a ocupação na região é muito antiga, dados levantados nessa pesquisa comprovam que antes da chegada dos europeus a região era usada como rota de ligação entre o planalto e o litoral.

Serra João Ferreira, rio Pinheiro Nunes, ribeirão Rodrigues, córrego Soares, rio André Lopes, rio Pedro Cubas, córrego de Francisco Gomes, córrego Maximiniano, córrego dos Marques, entre outros, denotam a importância do morador local, o ribeirinho, o caipira, o negro quilombola na construção de sentido do lugar nessa camada denominativa.

A compreensão mítica do espaço constitui-se em forma de narrativas míticas ou, então, na forma de topônimos que revelam 
estados anímicos. Na região do Petar os denominativos serra da Dúvida, serra do Sem Fim, serra da Paciência, bairro Inveja, são exemplos de um fazer denominativo que leva em conta impressões psíquicas do lugar, sendo difícil explicitar o motivo gerador do nome.

As narrativas são características dessa segunda camada denominativa e relatam o período em que a população negra estava ainda sob o regime escravagista, esse período vai até o início do século XVIII na região do Alto Ribeira. Uma dessas narrativas descreve a origem do denominativo Abismo do André: conta a história que, Dona Prudência da Motta, após ter acolhido e protegido o escravo fugidio André, manda matá-lo quando seu antigo dono descobre seu paradeiro. Teria pago a seu filho, Jeca da Motta, em libras esterlinas, para que jogasse o escravo em um abismo, conhecido, hoje como Buraco do André. Na década de 1940, teriam encontrado ali seus restos mortais.

Outra narrativa remete ao mito do Eldorado ou a montanha de ouro. Conta a história que um escravo de sobrenome Siqueira, da Vila de Apiaí, foge quando está preste a sofrer um castigo. Nesse percurso, atravessa um morro coberto de avencas e, ao escorregar, agarra-se em um punhada delas procurando equilibrar-se, mas as frágeis plantas não suportam seu peso e despregam-se do solo deixando à vista o terreno repleto de ouro. Ao levantar-se, o escravo percebe que todo o morro era feito de ouro. Tomou a decisão de voltar e levar consigo o quanto de ouro conseguisse, tentando, com isso, livrar-se do castigo e conseguir o perdão de seu amo. Encheu duas taquaras com o metal precioso e as entregou ao amo. Não só conseguiu o perdão como também a alforria. Ambicionando conseguir alcançar o morro e se apoderar de toda aquela riqueza, o dono do escravo preparou uma grande 
expedição para explorá-lo, porém jamais conseguiram encontrar o caminho que levava ao Morro das Avencas.

Contam que o engenheiro alemão, Emílio Grense, envelheceu e morreu procurando o Morro das Avencas. Percorreu todo o sertão entre Xiririca e Guapiara mas não conseguiu encontrar nada. Há relatos que afirmam que o Morro, na verdade, fica entre Pilões e Guapiara.

São essas narrativas que, no imaginário da população local, constroem significados que são parte da história e da identidade da comunidade.

\subsubsection{A implantação do Petar, nova configuração do espaço}

$\mathrm{Na}$ terceira camada, a implantação do Parque reformula o ato denominativo. Nessa fase, os valores como preservação ambiental e desenvolvimento sustentável começam a fazer parte do cotidiano dos moradores locais.

As Unidades de Conservação que foram implantadas em, aproximadamente vinte por cento do território do Vale do Ribeira tornaram-se um entrave para uma população que usava a terra para sua sobrevivência.

Como já dito a comunidade do entorno do Petar sentiu o problema quando o Parque foi demarcado, no início dos anos de 1980. As restrições de uso da terra afetaram toda a comunidade local, pois a maioria obtinha seu sustento de atividades agrícolas tradicionais e do extrativistas vegetal e mineral, atividades essas, predatórias que foram totalmente proibidas. Moradores que ocupavam áreas dentro do parque sofreram mais com as restrições. Até os dias de hoje, há problemas ainda não completamente solucionados em relação a essas populações como é o caso da comunidade de Bombas, cujo reconhecimento e 
titulação da área ocupada pela comunidade quilombola não está totalmente resolvido.

Por outro lado, as atividades ligadas ao turismo, surgidas com a implantação do Parque, trouxeram novas perspectivas para os moradores locais. A criação de frentes de trabalho ligadas ao ecoturismo envolvendo, em especial, os mais jovens que não encontravam perspectiva de emprego na região e ameaçavam abandonar o lugar em busca de oportunidade. As cavernas, trilhas e cachoeiras, passaram a fazer parte do cotidiano dessa população que agora tem na natureza preservada uma fonte de renda, de sustento.

Nesse novo contexto, as cavernas, cachoeiras e trilhas ganham nome. Esse fazer denominativo já não é levado a cabo pelo homem que vive na terra, ou mesmo tira seu sustento dela. $O$ explorador de caverna não faz parte da comunidade local, geralmente é um pesquisador ou um interessado no assunto que chega ao local para visitar ou pesquisar as cavernas e seu entorno e pouco participa de atividades com a população local. Isso faz com que os nomes dados quase não encontrem eco na história da região e na comunidade. Assim também é o turista, seu foco são as atrações ligadas ao meio ambiente natural, em especial as cavernas.

A configuração dos nomes mais recentes, deixa claro as relações tênues do denominador com o lugar. Tem-se no corpus desse trabalho o topônimo da gruta denominada Los Três Amigos, que no imaginário atual remete à criação de Angeli, Glauco e Laerte e, também, a três jovens que querem ser identificados ou que se identificam tanto com as personagens quanto com a descoberta de espaços, ou seja, faz parte do imaginário urbano dos descobridores e não tem referência com o local. Outros exemplos 
são gruta Tentativa e gruta Lição №1 que, claramente, demonstra a tênue ligação com a comunidade local, com a história local e com o mundo do Petar anterior a essas descobertas.

No entanto, vale ressaltar a preocupação entre os grupos de espeleólogos em manter um vínculo com o entorno no ato denominativo das cavernas. Clayton Lino, arquiteto, espeleólogo e um dos idealizadores da implantação do Petar, nos anos de 1980, declara que, de fato, existe compromisso, pois ao se denominar uma caverna recém-descoberta,por eles, profissionais, procura-se um referente próximo como uma montanha, uma pedra, uma árvore que marcará sua localização. Outra prática, bastante comum, seria o denominativo fazer uma referência a um acontecimento ocorrido durante a exploração. Exemplo disso seria a descoberta de ossadas de animal dentro da caverna, o encontro de um animal no entorno, um objeto que se perdeu ou foi encontrado na caverna, fatos que mantém referência tênue com o lugar. Tem-se gruta da Laje Branca, como referente de localização, gruta da Jararacuçu, porque encontraram uma cobra jararacuçu na entrada da caverna.

Essa camada denominativa pode ser compreendida como de quebra entre a comunidade local e a natureza preservada. Esse distanciamento é reflexo das restrições ao uso da terra imposta pela Unidade de Conservação. Os nomes de lugar são consequência dessa condição, o ambiente é denominado por quem não vive ali, os turistas, o pesquisadores, os exploradores são aqueles que denominam agora. Cada novo grupo procura deixar ali sua marca.

Não se está querendo dizer que a comunidade local fora excluída, há, sim, a participação de moradores no novo processo de apropriação do espaço, mas as relações com o meio mudaram. $\mathrm{Na}$ verdade, hoje eles são prestadores de serviço, as áreas 
permitidas para o plantio de roças são poucas e muito cerceadas, a criação de animais só é possível para o próprio consumo e ainda assim muito restrita. O bairro da Serra, Bombas e todas as comunidades vizinhas ao Parque sofrem fortes restrições em relação ao uso da terra.

$\mathrm{Na}$ presente pesquisa de campo, constatou-se que muitos lugares antes habitados por famílias estão perdendo sua população ou já perderam por completo,e, portanto, estão deixando de existir, isto é, os denominativos desses lugares já não são reconhecidos por grande parte da população local, ou, se reconhecem o nome de lugar não conseguem identificar sua localização. Como consequência dessa nova configuração do território percebe-se um aumento da nomenclatura dos acidentes físicos e uma diminuição dos nomes de acidentes humanos, em especial bairros rurais e sítios, reflexo do esvaziamento populacional do entorno do parque.

Tem-se consciência de que esse esvaziamento não se dá somente em razão da implantação da Unidade de Conservação, antes dela a região já sofria com a evasão dos mais jovens, mas as restrições impostas pelo parque modificaram as relações da população com o ambiente que veem-se refletidas na toponímia local.

Entende-se as taxionomias toponímicas como metáforas e, ou metonímias das relações do homem com o meio ambiente, ou, segundo Kövecses (2006), seriam disparadores das associações e, ou contiguidades contidas nos denominativos de lugar que atuam no sentido de contextualizar a comunidade ao lugar para que se apropriem do espaço e se identifiquem com o território tornando-o significativo (NORBERG-SCHULZ, 1980). As camadas denominativas explicitam as relações que, em diferentes épocas, o homem manteve com o lugar, as motivações justificam essas 
relações, ao classificar-se os denominativos de acordo com as taxes toponímicas, pontua-se interações importantes da população local com o meio ambiente.

\section{Petar}

O Petar foi criado em 19 de maio de 1958, com o objetivo de proteger as inúmeras cavernas e nascentes dos rios em um dos últimos remanescentes de Mata Atlântica do estado de São Paulo. Constitui-se em uma das Unidades de Conservação mais conhecidas e antigas do estado.

Petar é o acrônimo de Parque Estadual Turístico do Alto Ribeira. Até o ano de 1960 seu nome era Parque Estadual do Alto Ribeira, Pear; o termo turístico foi incorporado ao denominativo com a finalidade de fortalecer sua vocação voltada ao ecoturismo e tornar suas terras inalienáveis e de conservação perene.

Somente nos anos de 1980 o Parque foi de fato implantado e, só a partir daí os problemas com a comunidade local surgiram, até então sabia-se da existência do Parque mas não se conhecia seus limites e as limitações que uma Unidade de Conservação impunham ao uso da terra.

As transformações que a implantação do Parque causou foram significativas principalmente para as populações estabelecidas no entorno da Unidade de Conservação e, mais ainda, para aquelas localizadas dentro de seu perímetro, como já citado anteriormente. Essas transformações estão refletidas nos denominativos da região. A concepção do lugar muda; preservação ambiental, ecoturismo são as novas significações que a implantação do parque traz. A configuração do espaço também muda, a demarcação do parque traça limites em uma paisagem 
que anteriormente era conceitualizada em termos de um sentimento de localidade (LINO, 1978).

Conceber uma área grande, aberta, como o Parque, com fronteiras rígidas, não fazia parte do conceptus espacial da população da região. A implantação dos núcleos de visitação (Santana, Ouro Grosso, Caboclos e Casa de Pedra) e a participação da comunidade nas atividades de ecoturismo implementadas pelo parque colaboraram no sentido de conscientizar a comunidade em relação à nova estrutura espacial vigente.

Dentro desse contexto, a população local desenvolveu conceitos metafóricos em que a área do Parque é compreendida como um recipiente, estar dentro ou fora do Parque são expressões comuns no entorno do Petar: "Morro do Chumbo, é aqui dentro do Petar" (ouvimos de um morador do Bairro da Serra em uma de nossas visitas).

A chegada dos turistas alterou a concepção de grupo no sentido de quem está dentro e de quem está fora do grupo:

Dona Luiza, moradora do Bairro da Serra disse que os moradores do Bairro ficaram querendo levar vida de gente de fora, e muitos menosprezavam a agricultura (SILVEIRA, 2000, p.175).

Também aqui a comunidade é conceitualizada como um recipiente em que os turistas e pesquisadores são os de fora.

Turistas e pesquisadores têm concepções divergentes em relação ao Parque. Do ponto de vista dos pesquisadores e espeleólogos o parque é conceitualizado em função de seu grande acervo a ser explorado, em especial as cavernas, não só a parte física das grutas mas também a fauna e a flora cavernícola, 
sensíveis a qualquer mudança no ambiente, portanto a preservação ambiental para esse grupo é primordial.

Para os turistas que investem tempo e dinheiro com o objetivo de conhecer as cavernas e participar de atividades ligadas ao ecoturismo a conceitualização se dá mais em função da satisfação de suas expectativas. Portanto, a preservação deixa de ser fundamental, não que ela não exista, mas não está explícita em seu comportamento quando de sua visita ao Parque. Se o número de visitantes em uma caverna excede o permitido não cabe a ele, o turista, se posicionar em defesa da proteção ambiental.

O morador local e os de fora que conseguiram se beneficiar com as novas fontes de renda geradas pelo parque conceitualizam - lugar sob a perspectiva de seu potencial turístico. Trilhas, cachoeiras, grutas e atividades ligadas ao ecoturismo e ao turismo radical (boiacross, cascade, rapel em cavernas) agregadas à presença dos turistas compõem o campo semântico do Petar para essa população. A preservação ambiental é importante, para esse grupo, mas não a ponto de limitar suas atividades, principalmente porque o turismo é sazonal e deve-se, portanto aproveitar os períodos de grande fluxo de turistas.

Para os moradores tradicionais que não conseguiram se beneficiar com o turismo proporcionado com a implantação do Petar a conceitualização do lugar se dá em função das restrições a que estão sujeitos impostas pelas leis de preservação ambiental. Eles tiravam seu sustento de suas roças de coivara e de atividades extrativistas tanto mineral como vegetal, para essa população o desenvolvimento sustentável ${ }^{83}$ é possível e desejado para a região.

83 Desenvolvimento sustentável é o desenvolvimento capaz de suprir as necessidades da geração atual, sem comprometer a capacidade de atender as necessidades das futuras gerações. É o desenvolvimento que não esgota os $\begin{array}{lllll}\text { recursos } & \text { para } & 0 & \text { futuro. } & \text { Disponível }\end{array}$ 
A conceitualização dos diferentes sujeitos em relação ao Petar revela a complexidade de seu entorno.

A relevância do Parque como uma das mais importantes Unidades de Conservação do estado de São Paulo, considerada Patrimônio da Humanidade com suas mais de 200 cavernas, 0 ecoturismo e as pesquisas desenvolvidas em seu entorno nas várias áreas do conhecimento são traços semânticos presentes no acrônimo Petar, nesse sentido pode-se considerar Petar como uma lexia, ou melhor, trata-se de um topônimo. Petar como o nome do lugar já foi assumido no logo do Parque, nesse sentido Petar é apresentado como uma lexia. No percurso dessa pesquisa muitas pessoas referiram--se ao Parque como Parque Petar. O sentido do acrônimo pode acabar desaparecendo e, Petar, se afirmando como o nome do lugar, sendo necessário acrescentar o termo genérico parque, da mesma forma como nos topônimos de origem indígena em que o termo genérico rio não é reconhecido como integrante da lexia (Yundiá- $y>$ rio dos jundiás).

\section{Bairro da Serra}

Serra é topônimo do bairro mais desenvolvido do município de Iporanga.

O bairro da Serra, como já citado, está situado a sudeste do Petar no sopé da serra de Paranapanema ( LINO, 1980,p.12), é a porta de entrada para visitação do núcleo Santana e Ouro Grosso. Ao visualizarmos no mapa percebemos que o bairro está praticamente inserido no Parque, com uma pequena abertura que permite sua ligação com as cidades do entorno, Iporanga e Apiaí. 
A região que hoje é conhecida como bairro da Serra era, no passado, composta por vários bairros rurais: serra dos Motta, Macaquinhos, Passagem do Meio. Bairro Serra de Iporanga era como os moradores da cidade de Iporanga se referiam ao local.

Com o crescimento do bairro a memória dos primeiros moradores foi-se diluindo, apesar do vínculo entre os moradores ainda ser em grande medida por laços de parentesco. A história de Dona Prudência da Motta, a primeira moradora do lugar, já não se faz conhecida por todos.

No começo da década de 1960, chegaram os primeiros espeleólogos; se acomodavam no bairro da Serra local próximo às cavernas. De acordo com sua visão do lugar, ali era o Betari por estar às margens do rio Betari. Esses espeleólogos não tinham nenhuma ligação com a história e a dinâmica da comunidade local. Conceberam o espaço a partir de sua perspectiva, a exploração das grutas, e definiram um lugar ao denominá-lo Betari. O conceptus do lugar para os espeleólogos não era o mesmo daquele dos moradores locais, as relações significativas que cada grupo mantinha com o espaço eram completamente diferentes. Nesse sentido, o denominativo Betari representava o mesmo espaço, mas concebido como lugares diferentes de acordo com os diferentes nomes. Segundo Tuan (1983), o espaço transforma-se em lugar a medida que adquire definição e significado. Para os espeleólogos aquele espaço adquiriu definição e significado referencializando as cavernas, a mata e, principalmente, o rio Betari, referente principal para quem, de fora da comunidade, chegava ao bairro. Já os moradores locais construíram o conceito do lugar baseado nos laços de parentesco, nas roças de coivara, na troca de favores entre vizinhos, nas trilhas das tropas. 
Os moradores da cidade de Iporanga concebiam o lugar sob outra perspectiva, o foco principal era a posição geográfica, localizado serra acima, em uma região coberta por matas e montanhas; se referiam ao lugar com o denominativo Bairro da Serra de Iporanga. Analisando o sintagma toponímico, atribui-se duas possibilidades de significado do denominativo que podem esclarecer o percurso gerativo de sentido do topônimo Bairro da Serra.

A primeira leva em consideração a localização do bairro, na serra de Iporanga, nesse caso o ponto de vista dos moradores seria a localização do bairro na serra de Iporanga.

- Bairro da Serra de Iporanga - Serra de Iporanga seria a localização e Bairro o nome do lugar, ou o termo específico; a preposição de (+a) indicaria origem, local.

Porém, não existe no entorno do Petar nenhuma serra denominada serra de Iporanga, portanto o sentido do sintagma não indicaria o local onde está situado o bairro já que esse local não é parte da estrutura denominativa da região.

A segunda possibilidade de acepção levaria em consideração o município de Iporanga, e, bairro e serra seriam o nome do lugar.

- Bairro da Serra de Iporanga - Bairro da Serra seria o nome do lugar ou o termo específico e lporanga o município a que pertence o bairro, a preposição de indicaria pertencer a, mais do que localizado em.

Mudando o referencial, muda-se o sentido do topônimo, temos portanto Bairro da Serra como nome de lugar. Essa talvez seja a gênesis do denominativo Bairro da Serra. Nesse contexto, entendeu-se o termo bairro compondo o sintagma toponímico junto com serra. 
Há outra possibilidade para explicar o percurso do denominativo Bairro da Serra, tendo como referência o próprio bairro e as transformações pelas quais passou com a implantação do Parque. Com o esvaziamento dos bairros rurais no entorno de Iporanga os nomes dos bairros perdem significado; a região do bairro da Serra passa por uma resignificação do espaço, levando mais em consideração os acidentes físicos do que os humanos em função da valorização da preservação ambiental. Nesse sentido o termo específico que ligava o topônimo à comunidade local, Mottas, deixa de referencializar o lugar e de signo marcado passa a signo não marcado quando perde o termo específico, toponimizando o termo genérico, Serra. È comum na região dizer moro na Serra. Para os moradores da região, Serra pode ser o topônimo e bairro o termo genérico.

Para Dick, o termo genérico se torna topônimo quando o acidente é único ou muito representativo na região. Portanto, não havendo necessidade de um termo específico para individualizá-lo. Não é esse o caso, pois a região do Petar está coberta por serras, como já vimos, temos serra da Anta Gorda, serra da Onça Parda, serra da Samambaia, serra das Arapongas, serra do Baú, serra da Boa Vista e outras.

A implantação de Unidades de Conservação no entorno de Iporanga ocasionou uma nova configuração do espaço. A natureza passa a ser a maior protagonista nas relações com o lugar, nesse sentido o topônimo Serra pode, também, refletir essas novas relações em que se prioriza os aspectos físicos do lugar e não os aspectos humanos.

\section{Cavernas:}


Os atrativos mais procurados pelos visitantes do Petar são as cavernas. Richard Krone foi quem apontou o potencial turístico da região quando investigou várias cavernas no início do século $X X$. $A$ exploração sistemática teve início nos anos de 1960, com destaque para o grupo de franceses encabeçado por Pierre Martin.

A maioria dos nomes de cavernas corresponde à última camada denominativa da região do Petar. Com a exploração sistemática das cavernas novos denominativos foram incorporados à estrutura toponímica do entorno do parque.

De acordo com a Sociedade Brasileira de Espeleologia ${ }^{84}$ :

Caverna é um termo geral que define qualquer cavidade natural com uma ou mais entradas, seca ou não e com um ou mais rios internos, com predominância horizontal ou não. Gruta é a designação de cada cavidade espacial subterrânea natural com predominância horizontal e um mínimo de 50 metros de desenvolvimento possuindo em seu interior uma região permanentemente em trevas (região afótica). Se a caverna possui desenvolvimento menor que 50 metros é denominada toca. Por outro lado quando uma caverna apresenta predominância vertical e tem desenvolvimento mínimo de 14 metros, recebe a denominação de abismo. Caso esse desenvolvimento mínimo na seja atingido denomina-se fosso. (LINO, 1975)

Consta do corpus desse trabalho 43 nomes de cavernas em um universo de mais de 200 catalogadas, a carta geográfica foi a principal fonte de coleta dos nomes. Nota-se que os termos genéricos caverna e gruta são usados de forma arbitrária. A pesquisa de campo também confirmou esse dado, os moradores locais e os monitores ambientais não fazem distinção entre os termos gruta e caverna.

${ }^{84}$ LINO, C. Ferreira. Terminologia e Nomenclatura Espeleológica. São Paulo, SBE, 1975. 
A idade aproximada das cavernas está entre 1,7 milhões a 2 milhões de anos no mínimo. A diversidade morfológica dos espeleotemas são o maior atrativo para quem visita uma caverna. Espeleotema é o termo genérico ou, hiperônimo, de todas as formações rochosas que ocorrem dentro de uma caverna. As principais e mais conhecidas são os estalactites (aqueles que pendem do teto), os estalagmites (que crescem do chão para o teto como resultado do acúmulo de gotas) e os helictites ( crescem em qualquer direção desafiando a gravidade). Nomes como cortinas, pérolas, discos, jangadas, escorrimentos, agulhas, flores, vulcões, canudos de refresco, descrevem outras formações que são denominadas por analogia, processo metafórico, com a realidade externa. Conceitualizar o universo subterrâneo por meio das experiências cotidianas é parte do processo de compreensão do mundo das cavernas.

Lakkof e Johnson (1980) afirmam que nosso sistema conceitual é em grande medida metafórico a maneira como pensamos, o que experimentamos e o que fazemos cada dia também é em grande medida coisa de metáfora. Foi descoberto um novo conduto na caverna Santana denominado, Conduto Primeira de Susy. O denominativo denota a analogia entre a atividade subterrânea e uma experiência cultural fundamental na vida cotidiana das pessoas.

Após alguns metros, alargando a pequena passagem, a galeria se tornou ampla o suficiente para permitir o caminhamento de joelhos, resultando em um prolongamento por mais 20 metros e encerrando de forma instransponível com a rocha calcária obstruindo o caminho, e assim agregamos um novo conduto à 
topografia da Caverna de Santana, denominado Conduto Primeira de Suzi, fazendo menção a exploração com desobstrução ${ }^{85}$.

A história de exploração da caverna Santana é antiga, data do início do século $X X$ e continua até hoje. Atualmente, segundo o Grupo Pirerre Martin de Espeleologia são os seguintes dados de desenvolvimento da caverna : 8255 metros de projeção horizontal, 8421 metros de desenvolvimento linear e 63 metros de desnível.

A cada nova descoberta, tem-se uma nova denominação, os motivos geradores desses nomes refletem novas conceitualizações do lugar, provocadas pela chegada dos espeleólogos e pesquisadores após a criação do Petar.

Salão Pierre Martin: homenagem do GPME ao principal explorador da caverna Santana. Esse salão foi descoberto em 2012.

Salão Esther: homenagem de Pierre Martin à esposa de Alfons, casal de suíços que o acompanhavam na expedição.

Salão Berlindes: homenagem de Pierre Martin a um companheiro de exploração.

Galeria Irmãos Avari: homenagem de Pierre Martin aos irmãos Fabio e Roberto Avari, companheiros de exploração.

Galeria Teodoro Knech: homenagem ao engenheiro de minas Teodoro Knech que em 1930 explorou a caverna e percorreu uma distancia que ele estimou em 2000 metros.

Conduto Cascudo: em alusão a grande quantidade de cascudos, e referindo-se a dificuldade de acesso e caminhamento sempre baixo e estreito.

Floricultura: pela quantidade de buquês de helectites.

85 Grupo Pierre Martin de Espeleologia. Disponível em http://www.blog.gpme.org.br/?p=4924. Acessado em 17 de julho de 2013. 
Estreito do Afogado: menção a um incidente ocorrido durante uma expedição dentro da caverna em que Pierre Martin mergulha com sua luz apagada até o fundo do rio, perde os óculos, emaranha-se na corda e acha que vai se afogar enquanto seus companheiros morrem de irr $^{86}$.

Os denominativos em homenagem a algum membro da equipe de exploradores prevalece sinalizando uma ruptura com o entorno e valorizando o indivíduo, ou o grupo que realiza a expedição. A autopromoção predomina no fazer nominativo. A comunidade que vive na região não se vê representada, até porque adentrar a uma caverna nunca fez parte do cotidiano dos moradores locais. O ambiente cavernícola sempre esteve envolto em narrativas que induziam ao medo e mistério para a população local.

Floricultura descreve as formações rochosas que ocorrem no local, fazendo analogia com o que se vivenciou no ambiente externo; conceitualizar a caverna de acordo com a experiência do ambiente externo é parte do processo de compreensão desse ambiente desconhecido. Os nomes das cavernas Pérolas, Cristal, Cogumelos configuram também o caráter metafórico existente entre o ambiente interno e externo da gruta. A necessidade de se orientar e identificar no ambiente escuro das cavernas resulta em processos metafóricos e /ou metonímicos com o mundo externo. O sistema conceitual se desenvolve baseado em nossas experiências, nesse sentido aterrissar na lua é muito mais significativo que alunissar.

Conduto Cascudo, o processo metonímico da parte pelo todo explicita a primeira acepção do topônimo: pela grande quantidade de cascudo (tipo de peixe). O segundo significado faz alusão à

86 Em homenagem a Pierre Martin 1932 - 1986. Disponível em http://www.gpme.org.br/documentos/cat view/52-pierre-martin. Acessado em 02 de agosto de 2013. 
experiência vivida ao se adentrar no conduto. A metáfora está baseada no tipo de formação do conduto e na dificuldade em se ultrapassá-lo, conceitualiza-se o ambiente desconhecido por meio do que experimentamos no ambiente conhecido.

Estreito do Afogado, a nomeação está relacionada a um fato, um acontecimento; o que define o lugar é uma experiência vivenciada pelo grupo. Assim também os denominativos Lição Número 1 e Tentativa referem-se a relatos de experiências vividas por quem denominou as cavernas. São nomes que não tem referentes no entorno e poucos conhecem seu significado, nesse contexto um novo sentido é construído para que o ambiente seja significativo e o homem possa habitar, ou melhor, identificar-se e orientar-se nesse ambiente.

A caverna Santana teve como primeiro denominativo o nome do principal rio que atravessa a caverna, rio Roncador; cavernas que foram exploradas há mais tempo também adotam o nome do rio como denominativo: Alambari de Baixo e Alambari de Cima, Ouro Grosso, Temimina, Couto. A relação metonímica explícita nesses nomes denota a importância que o grupo atribuía ao ambiente natural. A importância que as cavernas assumem no contexto do Petar muda o referencial do denominativo que passa de nome de rio a nome de caverna, como abordado acima.

Os antropônimos atribuídos aos nomes de cavernas não tem o mesmo significado daqueles atribuídos aos bairros rurais. Gruta Joaquim Justino, o termo específico do sintagma toponímico presta homenagem a Joaquim Justino dos Santos, o já citado J.J. Gruta Sophia, nome dado em homenagem à filha de Pierre Martin.

Quando os nomes de cavernas referencializam lugares com nome de pessoas (caverna Tobias), esses antropônimos já não agregam semas referentes à pessoa, sua carga semântica está 
relacionada ao lugar; Tobias é o lugar onde está localizada a caverna. Também o referencial locativo pode perder o sentido à medida em que o lugar deixar de ser significativo para a comunidade, nesse sentido Tobias passa a ser nome de caverna, sem relação com o lugar, nem a pessoa. Dentro desse contexto a mudança de sentido do topônimo é resultado das mudanças nas relações significativas do homem com o lugar.

Os denominativos indicativos da localização da caverna só mantém o traço semântico do local enquanto o lugar for significativo para a comunidade: abismo Onça Parda, caverna Arapongas, gruta Morro Preto, caverna Areias. Esses topônimos referencializam acidentes geográficos importantes no entorno do Parque. De acordo com Norberg-Schulz (1980) orientação e identificação são os aspectos primários para o homem sentir-se ou pertencer ao lugar (mundo); as montanhas, as serras são acidentes concretos que estruturam o espaço facilitando a orientação, mas também consistem em referenciais de identificação. Nesse sentido o nome dessas cavernas referencializam acidentes geográficos importantes no contexto do Petar, esses acidentes constituem a estrutura do espaço e, portanto, são parte da conceitualização do lugar. Nesses casos, o traço semântico referente ao acidente geográfico em que a caverna está localizada tende a se perpetuar.

Saindo da gruta o Seu Joaquim ressalta a existência de uma imensa árvore, conhecida como Quina Preta. E assim a gruta foi denominada" (Ericson Cernawsky lgual). ${ }^{87}$

Gruta da Marreta, gruta do Morcego Branco, gruta do Tatu, gruta Jararacuçú, caverna Cafezal, são topônimos gerados pelo mesmo processo de motivação que o topônimo Quina Preta, isto é,

${ }^{87}$ SANTOS, Joaquim Justino dos. Memórias de JJ - Um Caboclo Espeleólogo. São Paulo. All Print Editora, 2010, p.68. 
esses denominativos também referem-se a objetos, animais ou vegetais que se encontravam no entorno da caverna no momento da descoberta. A relação desses denominativos com o ambiente são significativas: morcego branco é animal típico de cavernas, tatu e jararacuçu, animais comuns em ambientes de florestas como o ambiente do entorno do Petar, marreta é um instrumento que pode ser usado para explorar cavernas. Cafezal referencializa uma antiga plantação de café na região da caverna. Dentro desse contexto as relações significativas entre nome e lugar (caverna) se dá por meio de processos metonímicos considerando esses objetos como parte do ambiente.

A gruta do Laboratório localizada no Bairro da Serra também conhecida pelo nome de Ressurgência das Areias ${ }^{88}$, é o local onde vive o bagre cego de Iporanga. Símbolo do Petar, esse animal troglóbio ${ }^{89}$ foi identificado por Ricardo Krone no ano de 1906, é o primeiro peixe de caverna descrito na América do Sul. Adaptou-se a escuridão eliminando as características que se tornaram desnecessárias em um ambiente sem luz, não possui olhos nem pigmentos na pele.

As cavernas que contém animais troglóbios são protegidas pela legislação como de relevância máxima, não podem ser destruídas, nem mexidas. Assim, nas cavernas do sistema Areias onde está localizada a caverna do Laboratório a visitação não é permitida.

O nome Laboratório refere-se a uma experiência desenvolvida nos anos de 1970, quando a caverna foi utilizada para a instalação do primeiro laboratório subterrâneo do Brasil. O objetivo desse

\footnotetext{
${ }^{88}$ Trata-se de uma gruta de 300 metros cujo rio subterrâneo ressurge de um sifão localizado no fundo da caverna. -Genthner, Ferrari, Karmann. Revista do Instituto Geológico 24 (1/2), São Paulo,2003.

${ }^{89}$ Animais troglóbios são animais que se especializaram para viver dentro de cavernas, em ambientes sem a entrada de luz.
} 
laboratório era desenvolver estudos sobre a gênese e desenvolvimento das cavidades do meio tropical e equatorial, sob os aspectos geológicos, físicos e químicos além da observação em ambiente natural dos troglóbios Sem recursos para a manutenção e para a assessoria científica o laboratório foi fechado (LIMA e MARINHO, 2001).

Conceitualizar cavernas como laboratórios implica em um processo metafórico que propõe a compreensão da atividade científica realizada dentro do espaço da caverna como similar à atividades realizadas em espaços de laboratório propriamente dito. O topônimo, caverna do Laboratório, agrega semas ligados à pesquisa e a espeleologia, os sujeitos do "laboratório" são normalmente sujeitos "de fora" da comunidade local.

No topônimo Ressurgência das Areias prioriza-se uma característica específica dessa caverna para representar o todo. A metonímia revela a importância da ressurgência (fenômeno) do rio subterrâneo no contexto do Sistema Areias. Bombas, comunidade quilombola onde está localizada a caverna, recebe esse nome devido ao estrondo que a ressurgência dessas águas fazem ao subirem para a superfície.

Até mesmo o denominativo que prioriza um aspecto intrínseco ao acidente, não representa a visão da população local. O termo ressurgência, não faz parte do universo lexical dessa comunidade, nesse sentido, também reflete a concepção do espaço de quem é "de fora". O topônimo Bombas é o que reflete o modo como a população conceitualiza o fenômeno, segundo moradores locais o estrondo da ressurgência das águas é muito parecido com o estouro de uma bomba. Nesse sentido, a metáfora é parte do processo de apreensão e compreensão do espaço tornando-o 
significativo, só assim o homem habita $(d w e l l)^{90}$ (NORBERGSCHULZ, 1980).

A ocupação do espaço, tornando-o lugar, pressupõe a apropriação não apenas física, mas, também, simbólica do espaço. $\mathrm{O}$ ato de nomear é a mais representativa dessas formas. Em cada estrato de ocupação do Petar, verificou-se uma nova estruturação do espaço e, portanto, uma nova camada denominativa. Como já visto, a escolha do nome não é arbitrária, elas revelam traços importantes da relação do homem com o lugar. Por meio das taxes toponímicas, explicita-se parte dessas relações.

Os primeiros a recortarem e denominarem a região do entorno do Petar, os indígenas, priorizaram nomes voltados à características do ambiente natural, as taxes toponímicas especificam essas relações. A metonímia, principalmente a parte pelo todo, presente na maioria desses topônimos de origem tupi, está traduzida nos zoos, fitos, hidro e geomorfotopônimos (Alambari, Guapiara, Iguape etc.). Segundo Lakoff e Johnson (1980), a metonímia não é simplesmente um procedimento referencial, ela tem também a função de proporcionar compreensão. Quando prioriza-se um aspecto do todo, ou do lugar, para representá-lo, a parte escolhida determina qual aspecto é significativo para aquela população. Nesse sentido, as motivações são também uma forma de conceitualizar o espaço, tornando-o lugar, os conceptus espaciais surgem da interação com o meio físico. Dentro desse contexto, os topônimos de origem tupi denotam aspectos importantes das relações dos povos indígenas com 0 meio ambiente do Petar.

\footnotetext{
${ }^{90}$ We may conclude that dwelling means to gather the world as a concrete building or "thing", and that the archetypal act of building is the Umfriedung or enclosure. Norberg-Schulz, 1980, p. 23.
} 
As alterações no ambiente podem gerar uma nova estrutura denominativa e, como consequência, uma mudança de sentido desses topônimos, mas a busca pela etimologia precisa contribui para o resgate do primeiro significado, isto é, revela traços importantes das relações dessas populações com o lugar.

O segundo estrato configura a tomada do lugar, primeiramente, pelo europeu e, depois, pela população negra. É um período longo que vai de meados do século $\mathrm{XVI}$ até o final do século XIX. A ocupação e apropriação do espaço foi lenta e rarefeita. Os períodos de desenvolvimento não chegaram a modificar a estrutura denominativa da região. $O$ traço mais significativo dessa camada são os antropônimos, representados pela figura do patriarca e/ou matriarca que se estabelecia no lugar com seus familiares, abria sua roça, e desse aglomerado surgiam os bairros rurais característicos dessa fase (Soares, Buenos, Maria Rosa, Camargos, Mottas, André Lopes etc.). Acidentes físicos como serras, rios e cachoeiras são denominados também com nome de pessoas.

Nesse sentido, a motivação é indicativa da valorização dos grupos comunitários nessa nova camada denominativa. O foco de convergência era o bairro rural que sobrevivia da agricultura de subsistência e de um sistema de trocas com os outros bairros vizinhos. A autonomia e um certo isolamento dos centros urbanos, justifica a centralidade no ser humano predominante na motivação dos denominativos de lugar.

Esse substrato denominativo é o mais significativo do Alto Ribeira. Essa população reestruturou o lugar de acordo com suas necessidades, se apoderou do espaço e como traço mais significativo dessa posse nomeou o lugar, ou renomeou-o, sabendo-se que a região era de alguma forma ocupada por 
populações indígenas. As comunidades quilombolas são, ainda hoje, representativas desse modelo comunitário, a origem comum é o traço mais marcante desses grupos formados, principalmente, a partir de relações de parentesco.

As Unidades de Conservação implantadas a partir do início do século XX reestruturam totalmente o lugar, territórios onde antes localizavam-se capuavas ou posses passam a ser área preservada, impossibilitando o uso da terra pelo homem. O espaço deixa de ser o lugar do homem que tira seu sustento da terra e passa a ser o lugar de toda humanidade. Dessa forma, um lugar não marcado que tem, na conservação ambiental, um benefício global e não propriamente local. A estrutura denominativa reflete essas novas relações. Há, portanto, um esvaziamento de sentido dos antropônimos que referencializavam os bairros rurais.

Novos sujeitos se apropriam do espaço, configurando-o lugar, mas um lugar conceitualizado a partir do modelo de natureza preservada. São esses novos sujeitos, que, de certa forma, reestruturam o sistema denominativo do entorno do Petar. Cavernas, cachoeiras, rios e trilhas são nesse contexto os objetos de orientação e identificação e, são eles que agora tornam o lugar significativo.

Percebe-se que a cada novo estrato de ocupação da região do Petar há uma nova configuração do lugar. O homem se apropria do espaço e ao torná-lo lugar reconfigura o que já existia, não há, portanto, ocupação isenta de uma certa destruição. Até mesmo as Unidades de Conservação, que propõe a preservação apagaram traços culturais importantes das populações tradicionais do Alto Ribeira contidos nos denominativos de lugar. 


\subsection{A preservação como o paradigma do entorno do Petar}

O Petar está inserido em um dos biomas mais ameaçados do território brasileiro, a Mata Atlântica. As ações de exploração começaram em 1500, com a chegada dos portugueses ao Brasil e a exploração do pau-brasil. Em seguida, vieram os ciclos da cana de açúcar, do ouro, da produção de carvão vegetal, da extração de madeira, da plantação de cafezais e pastagens, da produção de papel e celulose, do estabelecimento de assentamentos de colonos, da construção de rodovias e barragens, e da intensa urbanização, com o aparecimento das grandes metrópoles do país ${ }^{91}$. A Mata Atlântica é considerada uma das regiões mais ricas do mundo em biodiversidade, estima-se que existam em suas áreas cerca de vinte mil espécies vegetais o que representa aproximadamente trinta e cinco por cento das espécies existentes no Brasil.

A degradação do bioma relaciona-se, principalmente, ao fato de que compreende parcela significativa da população nacional. A transformação de áreas de florestas em campos cultivados e a urbanização continuam apesar de todos os esforços de conservação. A Mata Atlântica compreende oito bacias hidrográficas, responsáveis pelo abastecimento de setenta por cento da população brasileira.

A criação dos corredores ecológicos que possibilitam o fluxo gênico ${ }^{92}$, evitando o isolamento das populações da fauna e da flora

Dicionário Ambiental. Disponível em: http://www.oeco.org.br/dicionarioambiental. Acessado em 12 de agosto de 2013.

92 Fluxo gênico, também chamado migração de genes de uma população para outra. Fluxo gênico inclui vários tipos de eventos diferentes, como pólen sendo soprado a um novo destino ou pessoas se mudando para outras cidades e países. Se genes são transportados a uma população onde esses genes não existiam previamente, fluxo gênico pode ser uma fonte muito importante de variação genética. Disponível em:

http://www.ib.usp.br/evosite/ev0101/llIC4Geneflow.shtml. Acessado em: 10 de agosto 2013. 
é parte dos esforços de proteção dos remanescentes da vegetação nativa. O Petar é parte do continuum ecológico de Paranapiacaba que representa uma das áreas mais significativas dos remanescentes florestais do Estado de São Paulo, com mais de 120.000 ha.

O Petar também está inserido na maior área de remanescentes de quilombos do Estado de São Paulo, o Vale do Ribeira. A história dessas comunidades teve início há pelo menos trezentos anos quando os primeiros escravos chegaram à região, ou, como explica Benedito Alves da Silva, líder da comunidade de Ivaporunduva: "foram trazidos, não veio por que quis".

De acordo com Maria Ignez Maricondi, da Fundação ITESP, os quilombolas são grupos com terras que se estabilizaram há muito tempo na região (jamais abandonaram suas terras). Essas terras só não estão regularizadas, diferente de assentamento em que são pessoas que não tem a terra e vão adquiri-las para trabalhar. Há uma dívida histórica com essa população, eles vieram escravizados e a abolição não os contemplou com terras, ficaram sem nada ${ }^{93}$. Sem a regularização das terras devolutas que Ihes são de direito essas comunidades ficaram abandonadas até a década de 1960, não tinham estradas, escolas, o acesso era difícil e a mobilidade se dava, principalmente, por meio de canoa.

Benedito Alves da Silva explica que ser quilombola é resistência, luta e preservação da história. Sem a luta pela preservação da história perde-se a identidade étnica, a cultura e os vínculos com o lugar. Esse grupo está construindo sua história que aparentemente se perdera e deve ser resgatada, sobretudo, por

93 Resgate Histórico: Conheça o trabalho do Governo de São Paulo nas comunidades quilombolas. Disponível em:

https://www.youtube.com/watch?feature=player embedded \&v=12YrUpFXzkU\#t= 222. Acessado em10 de agosto de 2013. 
meio dos depoimentos orais que se vai buscar na memória dos mais velhos, diz ainda, Maria Ignez Maricondi.

Das vinte e oito comunidades quilombolas reconhecidas no Estado de São Paulo até o primeiro semestre de 2013, a maioria se encontra no Vale do Ribeira.

O Petar reside nessas duas concepções de lugar que, a princípio, podem parecer antagônicas: preservação ambiental e preservação cultural.

A relação entre essas duas concepções de lugar se dá por meio da palavra preservação que de acordo com o Dicionário Aulete:

$$
\begin{aligned}
& \text { Preservação }{ }^{94} \text { 1.Ação ou efeito de preservar(-se). } \\
& \text { Conservação, proteção, resguardo. }
\end{aligned}
$$

Conservação, proteção, resguardo e preservar-se são paradigmas que fazem a intersecção entre o ambiente natural e o ambiente cultural. Como Unidade de Conservação, o Petar cristaliza paisagens que contém objetos concretos de identificação e orientação referentes a estruturas condicionadas culturalmente pelas populações tradicionais, por exemplo, as trilhas de tropeiro, o cedro, marco do local onde havia um cruzeiro que era ponto de parada de descanso daqueles que levavam os defuntos para enterrar em Iporanga, o canto da araponga, o estouro da água dentro de uma caverna.

O resgate da história e, consequentemente, o regaste da identidade étnica dessas comunidades está em função dos lugares e das coisas que exerceram o papel de construir uma base existencial significativa para as populações. Em geral, conhece-se "realidades" (lugares) que conduzem nossa existência, a paisagem

94 iDicionário Aulete. Disponível em http://aulete.uol.com.br/preserva\%C3\%A7\%C3\%A3o. Acessado em agosto de 2013. 
onde vivemos não é um mero fluxo de fenômenos, ela tem estrutura e incorpora significados. Essas estruturas e significados deram origem às mitologias as quais formaram as bases do habitar (dwell) (NORBERG-SCHULZ, 1980). É nesse sentido, que a preservação ambiental e a preservação cultural coexistem no espaço do Petar, como parte de uma totalidade significativa do ser e estar do homem, ou melhor, de identificação e de orientação.

Lynch $^{95}$ afirma que todas as culturas desenvolveram sistemas de orientação, isto é, estruturas espaciais que facilitam o desenvolvimento de uma boa imagem do ambiente. A paisagem deve ser organizada em torno de um conjunto de pontos nucleares, ou ser recortada em regiões denominadas, ou ser ligada por rotas que estão na memória. A toponímia do Petar revela a estrutura espacial que foi construída ao longo do tempo pelos diferentes sujeitos deixando impresso nessa edificação parte de sua identidade ou, melhor, como, muito mais do que onde, ele se relacionavam com o lugar. Mais que a carta geográfica, as estruturas espaciais mentais delimitam lugares significativos que são parte da história da comunidade. No corpus dessa pesquisa consta um riacho com o nome de Corguinho, mais do que referencializar o lugar esse topônimo referencializa uma população; traços culturais compõe a morfologia do denominativo. Corguinho é uma corruptela do diminutivo de córrego, ou melhor, é a identificação da população local com o denominativo, para que o lugar se torne significativo a população precisa se reconhecer no topônimo. Assim, o topônimo passa a ser uma metáfora do lugar.

A cristalização da paisagem não foi acompanhada pela cristalização da estrutura denominativa do lugar. A criação da Unidade de Conservação mudou as relações do homem com o

${ }^{95}$ Lynch apud Norberg-Schuz. Cenius Locci. New York. 1980, p.18. 
espaço e, dessa forma, mudou a estrutura denominativa. Apesar de muitos nomes terem sido preservados nessa nova configuração, a relação significante/significado mudou. A partir do momento em que o referente muda, ou se transfigura, o significado do nome também muda. Como já visto, o desaparecimento ou esvaziamento de bairros rurais no entorno do Parque fez com que o sentido de muitos denominativos mudasse. Caboclos, antes referente de bairro rural, com o desaparecimento de sua população passou a ser indicativo de núcleo de visitação do Petar. Portanto, o significado do nome mudou.

No sentido de preservar a história e manter vivo o espírito do lugar (genius $\operatorname{loci}^{96}$ ) as comunidades tradicionais guardam suas narrativas míticas. Essas narrativas são metáforas que explicitariam relações físicas e psíquicas que as comunidades mais antigas mantinham com o ambiente. Da mesma forma que as paisagens cristalizadas são referentes importantes para o resgate da memória dos antigos moradores essas narrativas também são parte da construção de uma história que está perdida e deve ser resgatada para que se mantenham vivos os traços étnicos dessas comunidades.

Sebastião Salgado ${ }^{97}$ alega que os brasileiros são o único povo que ainda convive com sua pré-história (os grupos indígenas não contatados). Nesse sentido, há a necessidade de se preservar nossas florestas como forma de preservar a história. Os territórios ocupados pelas populações indígenas são terras da união e,

\footnotetext{
${ }^{96}$ G Genius loci is a Roman concept. According to ancient Roman belief every independent being has its genius, its guardian spirit. This spirit gives life to people and places, accompanies them from birth to death, and determines their character or essence" (NORBERG-SCHULZ, 1980, p. 18).

97 Fotografei $O$ que foi interessante para mim. Disponível em http://tvcultura.cmais.com.br/rodaviva/roda-viva-entrevista-sebastiao-salgado. Acessado em 12 de setembro de 2013.
} 
portanto, de todos os brasileiros, o principal papel dos indígenas é o de guardiões dessas matas.

Pode-se fazer a mesma analogia com as populações tradicionais do Alto Vale do Ribeira. Resgatar sua história é resguardar parte do passado. Essas comunidades ficaram isoladas por muito tempo e, de certa forma, foram guardiães daquelas matas. Há estudos que consideram que suas práticas agrícolas contribuíram para a conservação do meio ambiente.

"Surpreendi quando eu discubri que eu era negra, era negra. Eu num sabia não, num sabia. Pra nóis aquilo não era nada....", depoimento de dona Jovita Furquim de França, líder da comunidade quilombola do Galvão ${ }^{98}$.

Ao ficarem isoladas essas comunidades construíram modelos referenciais próprios, a cor da pele não era um traço relevante, ser negro,portanto, era um signo não marcado, como disse dona Jovita, aquilo não era nada. A construção de estradas e uma maior interação com os meios sociais urbanos resultou em uma nova configuração dos modelos conceituais dessas populações, 0 aspecto mais relevante foi a consciência de sua identidade étnica, de sua alteridade, ou seja, a cor da pele como um dado cultural. $\mathrm{O}$ que antes era um signo não marcado (o traço negro da pele), passa a signo marcado. A Constituição Federal de 1988 em seu Artigo 68, que instituiu o direito à terra aos Remanescentes das Comunidades dos Quilombos, e a proteção ao seu patrimônio cultural foi fundamental para essa tomada de consciência, em busca de seus direitos essas comunidades passaram a ter noção da importância

\footnotetext{
98 Resgate histórico: conheça o trabalho do governo de São Paulo nas comunidades quilombolas. Disponível em https://www.youtube.com/watch?feature=player embedded\&v=12YrUpFXzkU\#t= 222. Acessado em 16 de setembro de 2013.
} 
de seu passado histórico e étnico e a cor da pele era o traço mais significativo de sua origem étnica comum.

Os denominativos do entorno do Petar, por um lado, guardam a memória de um passado que deve ser recuperado e, por outro, explicitam novas relações com o meio ambiente que deve ser conservado e protegido, isto é, preservado. Há também, nessa transição de modelos uma mudança do sujeito que denomina: antes o morador local era quem denominava e estruturava o lugar. As novas propostas de conservação ambiental mudaram a estrutura espacial, uma nova população se apropriou do lugar e passou a denominar, esses nomes refletem essas novas relações. Surge uma nova concepção do lugar e, não mais local, mas agora, global, no sentido de que a preservação ambiental é um bem para toda a humanidade, foca não só o hoje mas, principalmente, o amanhã.

Assim, também, restaurar a história do lugar tem o mesmo sentido de preservar a natureza, isto é, restaurar para que as novas gerações possam construir sua história. Como disse Sebastião Salgado, nós não temos história, buscamos a história média do europeu, do asiático, vamos buscar a pré-história dos outros.

A região do Petar associa a história como paradigma do passado, e a preservação da natureza, como paradigma do futuro convivendo de forma harmoniosa com uma comunidade que deixou de ser local e passou a ser global com a chegada de turistas e pesquisadores. Junto aos remanescentes de Mata Atlântica preservada, outro grande atrativo da região é o confronto entre passado e futuro explicitado especialmente pela população do entorno do Parque. 


\section{Considerações Finais}

Traços da diversidade étnica, da história e da cultura da região do Petar refletidos nos denominativos de lugar reforçam a importância da interdisciplinaridade nos estudos toponímicos. O levantamento de dados históricos da ocupação da região foi fundamental para justificar a apropriação do lugar pela comunidade local. Circunstâncias marcantes que denotam a diversidade da região puderam ser justificadas por meio do levantamento historiográfico.

Dentro desse contexto histórico, classificou-se os topônimos de acordo com as camadas denominativas: a primeira camada refere-se aos denominativos de origem indígena, em sua maioria tupi, que se pressupõe sejam remanescentes das primeiras ocupações no Vale do Ribeira, antes mesmo da chegada do europeu. A segunda camada tem início no século XVI, com a chegada do explorador europeu à região, em especial os garimpeiros à procura do ouro de aluvião. Essa fase vai até o final do século XIX, abarca um período longo mas que não apresenta mudanças significativas na estrutura denominativa. $O$ traço histórico mais significativo dessa época, explícito nos denominativos de lugar, é a formação dos bairros rurais, organizados pelos grupos ligados por laços de parentesco. A terceira e última camada comporta a criação das Unidades de Conservação na região do Alto do Ribeira, em especial a criação do Parque Estadual do Alto Ribeira, o Petar. As mudanças ocorridas no paisagem local, novamente, refletem-se na estrutura denominativa. Aquele que dá nome e, portanto, tem a 'posse' do lugar deixa de ser o morador local e passa a ser o espeleólogo, o pesquisador, ou o turista. Há uma mudança nos atores do fazer 
denominativo, o morador local não é mais aquele que possui física ou simbolicamente o lugar.

A região do Petar caracteriza-se pela miscigenação entre os grupos mais importantes que compõe a população brasileira: o índio, o português e o negro africano. Essa miscigenação pôde ser confirmada pela pesquisa realizada por Lilian Kimura e Regina Mingroni Neto (2012) do Instituto de Biociência da Universidade de São Paulo, as quais, por meio da análise de amostras do DNA de quilombolas da região do Vale do Ribeira, concluíram que tanto brancos quanto índios, além dos escravos negros, tiveram papel importante na formação dessas comunidades. Os dados historiográficos levantados estão em concordância com os resultados dessa pesquisa. Essa miscigenação étnica encontra eco na toponímia local, como visto ao expor a tabela na qual há listados os 180 topônimos que constituíram o corpus desta pesquisa..

A inserção de uma das mais significativas Unidade de Conservação do Estado de São Paulo no Projeto ATESP, o Petar, sugeriu enfoques distintos do signo toponímico em que a preservação ambiental tornou-se um dado relevante e necessário para explicitar as novas interações que as comunidades mantém com o meio ambiente.

A análise quantitativa dos topônimos revelou dados significativos sobre as relações entre a população e o ambiente, um número relativamente grande de antropônimos em uma região na qual predomina a paisagem natural parece demonstrar a importância que os bairros rurais, formados a partir de ligações de parentesco, tiveram na constituição da estrutura da paisagem local. Outro aspecto importante revelado foi a quantidade pouco expressiva dos hagiotopônimos encontrados no entorno do Petar, mesmo que os eventos religiosos tenham exercido grande 
influência na constituição social dessas comunidades e, ainda hoje, as comemorações religiosas sejam acontecimentos significativos para a maioria da população.

Ao confrontar esses dois aspectos relativos à motivação toponímica, o divino e o humano, verifica-se que a figura do homem referencializado no morador local, o caipira, o ribeirinho ou 0 quilombola sinaliza a importância dada ao indivíduo e aos vínculos existentes entre os grupos sociais da região. Certo isolamento que teria marcado a região seria o fator determinante na valorização do morador local. Os laços estreitos de cooperação e vizinhança, presentes em especial nos puxirões e reunidas, podem ter se firmado em consequência desse isolamento e acabaram se tornando o traço distintivo mais significativo das comunidades do Alto Ribeira.

O Vale do Ribeira se caracteriza por ser a região que concentra o maior número de comunidades quilombolas do Estado de São Paulo. A predominância da comunidade negra na área é bastante expressiva embora tenha-se verificado, na análise dos dados, que essa situação não se reflete na estrutura dos denominativos de lugar. A quantidade de topônimos de origem africana é praticamente inexpressiva no entorno do Petar. A ocupação do Vale do Ribeira pelo europeu é antiga, data do início do século $\mathrm{XVI}$, os negros africanos vieram junto com os exploradores de ouro, há dados que confirmam sua presença a partir de meados do século XVII. A antiguidade de sua presença na região, certo isolamento do grupo marcado pelos bairros rurais e a miscigenação com a comunidade indígena e portuguesa foram fatores significativos para a relativa caipirização dessa população, isto é, a não diferenciação entre a herança portuguesa, a herança 
indígena e a herança negra africana como descreve Antonio Cândido (1964).

$\mathrm{Na}$ abordagem do signo toponímico em seus aspectos conceptuais, partiu-se do conceito desenvolvido por NorbergSchulz (1980) de que também as relações do homem com o espaço devem ser consideradas sob a perspectiva conceitual do lugar, isto é, o lugar como parte integral de nossa existência. Todos os atos de nossa vida acontecem em um local determinado. Nesse sentido, o lugar não é simplesmente o local onde os objetos estão ou os fatos acontecem, mais importante é saber como os objetos são e/ou estão e como os fatos acontecem no lugar, quer dizer, é fundamental conhecer o caráter do lugar, as interações que mantemos com 0 ambiente definem 0 caráter do lugar $e$ determinam a abordagem conceitual do lugar.

O topônimo mais do que referencializar um lugar, o onde, contextualiza as relações do homem com o lugar, ou seja, o como. Tratou-se dos aspectos conceituais do nome de lugar sob a perspectiva da metáfora e metonímia tendo por base a abordagem de Lakoff e Johnson em se que se afirma que a maior parte de nosso sistema conceitual normal está estruturado metaforicamente. Dessa maneira, a motivação implícita nos signos toponímicos são também representações conceptuais do lugar, explicitam relações do homem com o espaço. O espaço, ou melhor, o lugar é conceitualizado como um recipiente ou um continente que comporta uma substância. No Petar é comum dizerem: estar dentro ou fora do Parque. "Mas Lambari é aqui dentro (do Petar)", excerto de relato de um morador do Bairro da Serra.

Dentro do contexto de que o nome de lugar denota relações conceituais do homem com o ambiente, a análise sob a perspectiva diacrônica dos denominativos do entorno do Petar, dividida em três 
camadas proporcionou uma visão panorâmica das transformações acarretadas nas diferentes épocas. Assim, o topônimo explicita as mudanças ocorridas tanto na paisagem física quanto na 'paisagem' social das comunidades, isto é, as transformações sociais ocorridas ao longo do tempo.

A apropriação do espaço, tornando-o lugar, configura, sempre, uma nova estruturação do espaço e, consequentemente, uma nova estrutura denominativa. No Petar, os vários grupos que ocuparam o lugar deixaram suas marcas e, ao mesmo tempo, reconfiguraram a paisagem existente, com isso muitos topônimos sofreram mudança de sentido. À medida em que se altera o referente, altera-se, também, as relações significativas do homem com o lugar, o que acarretaria a mudança das relações conceituais com o espaço. $O$ que antes era roça ou capuava de um grupo familiar, hoje é área preservada e, pode-se dizer, de propriedade de toda a comunidade mundial. A conceitualização do entorno do Petar sofreu uma transformação muito grande nesses últimos anos, transformação essa que precisou ser absorvida, ou conceitualizada pela comunidade local que era quem mais de perto interagia como o ambiente.

A alteração da paisagem em função da implantação do Parque refletiu-se mais intensamente no esvaziamento dos bairros rurais, em especial aqueles localizados no perímetro da Unidade de Conservação, com o desaparecimento do bairro os denominativos perdem o referente e, portanto, perdem o sentido. Muitos topônimos que referencializavam essas comunidades estão praticamente esquecidos, deixaram de ser parte da estrutura denominativa do lugar, só os moradores mais antigos ainda guardam na memória a história desses bairros. Outros, como o topônimo Caboclos, sofreram uma mudança de sentido. Com tal 
esvaziamento, Caboclos passou a ser referente de um importante núcleo de visitação do Petar e também é nome de caverna.

As cavernas constituem-se no maior atrativo do Petar, há mais de duzentas cavernas cadastradas, todas denominadas. A experiência com o ambiente desconhecido levou os exploradores a conceitualizar o lugar a partir de sua experiência com o ambiente externo. Nesse sentido, os nomes, em especial aqueles que definem o interior de uma gruta, são metáforas e/ou metonímias que relacionam o ambiente interno ao externo. Um novo conduto recém descoberto no interior da caverna Santana recebeu o nome de Conduto Primeira de Susy, em analogia à experiência com o mundo externo. De acordo com Lakoff e Johnson (1980), o sistema conceitual é em grande medida metafórico, nesse sentido pode-se dizer que compreendemos o mundo por meio de metáforas e /ou metonímias. A metáfora é principalmente uma maneira de conceber uma coisa em termos de outra e a metonímia, por outro lado, tem principalmente uma função referencial, que dizer, nos permite utilizar uma entidade por outra, porém a metonímia não se reduz a um procedimento referencial, ela também desempenha a função de proporcionar compreensão. Ao se conceitualizar o interior de uma caverna como o ambiente externo e conhecido, procura-se a compreensão de um meio desconhecido e adverso.

Os reflexos das transformações ocorridas com a implantação da Unidade de Conservação estão, principalmente, relacionados com as restrições impostas às atividades ligadas à terra como a agricultura, a criação de animais ou o extrativismo mineral e vegetal. Para essa população o Parque não trouxe os benefícios esperados, já que as atividades vinculadas ao turismo absorveu apenas uma pequena parte da população. A agricultura de 
subsistência ainda é a principal fonte de sustento de parte significativa dos moradores do Alto Ribeira.

A situação tende a ficar ainda mais complexa frente à possibilidade de privatização dos Parques Estaduais. Teme-se que a população local seja totalmente excluída dos benefícios originados pelo turismo ambiental. Em uma visita a Fernando de Noronha no início de 2013, pode-se perceber que a privatização das áreas mais rentáveis do Parque Marítimo não contemplou a população local; o mesmo pode vir a acontecer com a população do entorno do Petar caso haja, de fato, essa privatização. Esse processo gera a perda de protagonismo do morador local e, de certa forma, já está indiciado na região do Petar quando os moradores locais deixam de ser o principal agente do fazer denominativo.

As comunidades quilombolas da região do município de Eldorado, Ivaporunduva, Sapatú e André Lopes conseguiram junto aos órgãos públicos a instalação da primeira ETC Quilombola na região. O curso foi discutido com toda a comunidade e deu-se prioridade à agroecologia, com cursos que compatibilize as atividades agrícolas de uma forma vocacionada com o meio ambiente que é o grande problema que todos enfrentam na região.

A implantação de escolas técnicas e/ou superior voltadas para as necessidades da região e aos anseios do jovens, em concordância com a preservação ambiental, pode ser uma boa solução que garanta aos mais jovens sua autonomia financeira oferecendo uma perspectiva de futuro, sem que seja preciso abandonar o lugar.

Only when understanding our place, we may be able to participate creatively and contribute to its history (NOBERG-SCHULZ, 1980, 202). 


\section{Referências Bibliográficas}

AB'SABER, Aziz Nacib. Natureza primária de São Paulo de Piratininga. Scientific American, Brasil. São Paulo: ed. 25, junho de 2004.

Disponível em:

$<$ http://www2.uol.com.br/sciam/artigos/natureza primaria de sao p aulo de piratininga.html $>$ Acessado em maio 2013.

ALVES, leda Maria (Org.) A Construção da Normalização Terminológica no Brasil. São Paulo: Humanitas, 2001.

AMORIM.Cleyde Rodrigues. Relatório Técnico -Científico da Comunidade Remanescente de Quilombo IvaporunduvaEldorado/SP.ITESP 1998.

AZEVEDO, Aroldo de. Vilas e Cidades do Brasil Colonial - Ensaio de Geografia Urbana Retrospectiva, Boletim da FFCL da USP, nำ208, S.Paulo: 1956.

BARBOSA, Maria Aparecida. Lexicologia, Lexicografia, terminologia, terminografia: identidade científica, objetos, métodos, campo de atuação. In. II Simpósio Latini Americano de Terminologia. I Encontro Brasileiro de Terminologia. I Encontro Brasileiro de Terminologia Científica, Anais. Brasília: União Latina; CNPq; IBICT, 1992.

. Terminologização, vocabularização, cientificidade, banalização: relações. In: Acta Semiótca ET Linguística, V. 7. São Paulo: Plêiade, 1990.

- Campo Conceitual e campo lexical dos termos globalização e relações Mundialização: relações. In. Revista Brasileira de Linguística, V.19, n. 1. São Paulo: Plêiade, 1999. 
BARROS, Lídia Almeida. Les Noms Propres Doivent-lls Faire L'objet D'Etude de La Terminologie? In. Revista Brasileira de Linguística. v. 11, n.1. São Paulo: 2001 p. 61-71.

BENVENISTE, Émile. Problemas de Linguística Geral I. Campinas:

Pontes, 1995.

- Problemas de Linguística Geral II. Campinas, Pontes, 2006.

BLASIS, Paulo A. Dantas de. A Ocupação Pré- Colonial do Vale do Ribeira de lguape, SP: Os Sítios Líticos do Médio Curso. Dissertação de Mestrado apresentada ao Departamento de Antropologia sub- área de Arqueologia da Faculdade de Filosofia Letras e Ciências Humanas da Universidade de São Paulo. 1988.

BLOOMFIED, Leonard. Language. London: George Allen \& Unwin, 1967.

BOAS, Franz. Race, Language and Culture. New York: The Macmillan Company, 1940.

CABRÉ, Maria Tereza. La Terminologia Hoy: concepciones, tendências y aplicaciones. Ciência da Infomação. V. 24, n. 3, 1995.

CÂNDIDO, Antonio. Os parceiros do Rio Bonito: estudo sobre o caipira paulista e a transformação de seu meio de vida. São Paulo, Editora 34, 2003.

CARRIL, Lourdes de Fátima B. Terras de Negros no Vale do Ribeira: Territorialidade e Resistência. São Paulo, FFLCH/USP, Dissertação de Mestrado. 1995.

CASSIRER, Ernst. Linguagem e Mito. São Paulo: Perspectiva, 2006.

A Filosofia das Formas Simbólicas I- A Linguagem. São Paulo: Martins Fontes, 2001. 
A Filosofia das formas Simbólicas II - O Pensamento Mítico. São Paulo: Martins Fontes, 2004

CHARBONNIER, Georges. Arte, Linguagem, Etnologia. Entrevista com Claude Lévi-Strauss. Campinas: Papirus, 1989.

COSERIU, Eugenio. Princípios de Semântica Estrutural. Madrid: Gredos, 1977. . Sincronia, diacronia, e história: o problema da mudança linguística. Rio de Janeiro: Presença, 1979. . Lições de Linguística Geral (Tradução do Prof. Evanildo Bechara). Rio de Janeiro: Ao Livro Técnico, 1980.

CRESSOT, Marcel. O Estilo e as suas Técnicas. Lisboa: Coleção Signos, 1980.

DAUZAT, Albert. La geographie linguistic. Paris, Flammarion, 1922. Les noms de lieux. Paris, Delagrave,1932.

DICK, Maria Vicentina de Paula do Amaral. A Motivação Toponímica e a Realidade Brasileira. São Paulo: Edições Arquivo do Estado de São Paulo, 1990.

. Atlas Toponímico: Um Estudo de Caso. In. Acta Semiotica Et Lingvistica. V.6. São Paulo: Ed. Plêiade. 1996. p. 27-44 - Toponímia e Antroponímia no Brasil. Coletânea de Estudos. 2 ed. São Paulo: 1990.

. Rede de Conhecimento e Campo Lexical: Hidrônimos e Hidotopônimos na Onomástica Brasileira. In. Aparecida Negri Isquerdo; Maria da Graça Krieger (org.) As Ciências do Léxico. Campo Grande, MS: Editora UFMS, v. II, 2004. p. 121-130.

- O Português do Brasil no Período Colonial. In. V Congresso Nacional de Linguística e Filologia. Círculo Fluminense de Estudos Filológicos e Linguísticos. Cadernos do CNLF, vol. V, n. 06. Rio de Janeiro: 2002. p. 133-146. 
- Métodos e Questões Terminológicas na Onomástica.

Estudo de Caso: o Atlas Toponímico do Estado de São Paulo. In. Investigações Linguísticas e Teoria Literária, Recife: v.9, 1999. p. $119-148$.

- Caminho das águas, povos dos rios: Uma visão etnolinguística da toponímia brasileira. In. Investigação Linguística e Teoria Literária, v. 13-14, Recife: 2001b. p. 153172.

. O Sistema Onomástico: bases lexicais e terminológicas, produção e frequência. In. Oliveira, Ana M. Pinto Pires e Isquerdo, Aparecida Negri. In: As Ciências do Léxico. 2 ed.. Campo Grande: Ed. UFMS. 2001, p. 79-90. - Interrelação Léxico e Cultura na América Indígena. Estudo de Caso. In: Acta Semiótica ET Lingvistica. V.8. São Paulo: Plêiade. 2000.

A Significação Hiponímica e Hiperonímica nas práticas Onomásticas. In: Anais do I Encontro Nacional de GT de Lexicologia, Lexicografia e Terminologia da ANPOLL. Recife: 1998.

A investigação linguística na onomástica brasileira. In: Estudos de gramática portuguesa (III), V.14. Frankfurt: Eberhard Gärtner/Christine Hundt/Axel Schönberger (eds.) TFM.2000. p. 217-239.

Aspectos de Etnolinguística. A toponímia Carioca e Paulistana. Contrastes e Confrontos. In. Cadernos do CNLF, Série IV, n.10- Semântica e Lexicologia. Rio de Janeiro: 2001. p. 172-190.

A Dinâmica dos Nomes na Cidade de São Paulo 15541897. São Paulo: Annablume, 1997. 
DRUMOND, Carlos. Contribuição do Boror à Toponímia Brasílica.

São Paulo,Editora Universidade de São Paulo, 1965.

FAUCONNIER, Gilles. Mental Space, Aspects of meaning construction in natural language. New York/Cambridge: Cambridge University Press. 2003

FAULSTICH, Enilde. Metodologia para projeto terminográfico. In. Simpósios de RITerm - Atas 1988-2002. ed. Union Latina, 1990.

Disponível em: <http://www.riterm.net/actes/3simposio/faulstic.htm> Acessado em abril 2012

FELIZARDO, Alexandre J. Cavernas em foco. Espeleologia: Histórica e Cultural Mundial. São Paulo. Union Latinoamericana de Espeleilogia. 2010

FIGUEIREDO, Luiz Afonso Vaz de. Cavernas como Paisagens Racionais e Simbólicas. Imaginário Coletivo, Narrativas Visuais e Representações da Paisagem e das Práticas Espeleológicas. Tese de Doutorado apresentada ao Departamento de Geografia da Faculdade de Filosofia Letras e Ciências Humanas da Universidade de São Paulo.2010.

FILLMORE, Charles J. Lectures on Deixis. Stanford, Calif: CSLI Publications, 1997.

FOGAÇA, Isabela de F. Estudo das Transformações da Estrutura Física do Bairro da Serra, Entorno do Petar, Em Decorrência Da Atividade Turística. Campinas. Revista Científica da Seção de Espeleoturismo da Sociedade Brasileira de Espeleologia - Setur/SBE. 2008. Disponível em< http://www.sbe.com.br/ptpc v1 n1.asp > Acessado em julho de 2013

FOUCAULT, Michel. As Palavras e as Coisas. São Paulo: Martins Fontes, 2002.

FRANCO, Francisco de Assis Carvalho. Bandeiras e Bandeirantes de São Paulo. São Paulo: 1940. p. 30. 
FUNDAÇÃO INSTITUTO DE TERRAS DO ESTADO DE SÃO

PAULO. Disponível em <http://www.itesp.sp.gov.br/br/> Acessado em 23 abril 2013.

GASPAR da Madre de Deus, Frei. Notas Avulsas sobre a História de São Paulo- publicado pelo Instituto Histórico e Geográfico de São Paulo: V.I, 1899-1900, p.190.

GENOUVRIER, Emile; PEYTARD, Jean. Linguística e Ensino do Português. Coimbra: Livraria Almeidinha, 1974.

GENTHNER, FERRARI, KARMANN. Revista do Instituto Geológico 24 (1/2), São Paulo, 2003.

GIACOMINI, Rose Leine Bertaco. Conflito, Identidade $e$ Territorialização. Estado e Comunidades Remanescentes de Quilombos do Vale do Ribeira de Iguape. Tese de Doutorado apresentada ao Departamento de Geografia da Faculdade de Filosofia Letras e Ciências Humanas da Universidade de São Paulo.2010.

GREIMAS, Algirdas Julien; COURTÉS, Joseph. Dicionário de Semiótica. São Paulo: Cultrix, 1979.

GRUPO PIERRE MARTIN DE ESPELEOLOGIA, Disponível em

< http://www.gpme.org.br/> Acessado em abril de 2013.

GUERN, Michel Le. La Metafora y La Metonimia. Madrid: Ediciones Cátedra. 1076

HEIKKILÃ, Karen. Teaching through Toponymy: Using Indigenous Place-names in Outdoor Science camps.Saarrbrucken, Gemany. VDM VErlag Dr Muller, 2008.

HJELMSLEV, Louis. Prolegômenos a uma Teoria da Linguagem. São Paulo: Perspectiva, 2006.

HOFSTADTER, Douglas R. Gödel, Escher, Bach : An Eternal Golden Braid. London: Penguin Books. 2001 
HOUAISS, A.; VILLAR,M.S. Dicionário de língua portuguesa. Elaborado no Instituto Antonio Houaiss de lexicografia e banco de Dados da Língua Portuguesa S/C Ltda $2^{2}$ reim.; alt. Rio de janeiro: Objetiva, 2007.

INSTITUTO ESTADUAL DE FLORESTAS. Disponível em http://www.ief.mg.gov.br/ Acessado em julho de 2013.

INSTITUTO SOCIOAMBIENTAL . Relatório Anual de atividades 2003. Plano Trienal 2003-2004 Disponível em http://www.socioambiental.org/sites/blog.socioambiental.org/f iles/relatorios/rel2003.pdf Acessado em junho de 2013.

JAKOBSON, Roman. Linguística e Comunicação. São Paulo:

Cultrix, 1995.

JAKOBSON, Roman; MARTINET, André. Linguística e Significação, Rio de Janeiro: Salvat Editora do Brasil, 1979.

KARMANN, Ivo; FERRARI, José Antonio. Carste e Cavernas do Parque Estadual Turístico do Alto Ribeira (PETAR), Sul do Estado de São Paulo. Publicado em 18/01/2000. Disponível em < http://www.unb.br/ig/sigep/sitio043/sitio043.htm> Acessado em abril 2013

KIMURA,Lilian; MIGRONI-NETO, Regina Célia. Genomic ancestry of rural African derived populations from Southeastern Brazil. American Journal of Human Biology. Article first publish online: 2 NOV 2012. Disponível em http://onlinelibrary.wiley.com/doi/10.1002/ajhb.22335/abstract Acessado em 20 set 2013.

KÖVECSES, Zoltán. Language, Mind and Culture: A Pratical Introduction. New York. Oxford University Press. 2006.

Methaphor, language, and culture. Delta: Documentação de Estudos em linguística Teórica e Aplicada. vol.26 no.spe São Paulo 2010. Disponível em http://www.scielo.br/scielo.php?pid=S0102-

44502010000300017\&script=sci arttext Acessado em janeiro de 2013. 
KRIEGER, Maria da Graça; FINATO, Maria José B. Introdução à Terminologia. São Paulo: Editora Contexto, 2004.

KRUG, Edmundo. A Ribeira do Iguape. São Paulo. Secretaria da Agricultura, Industria e comercio do Estado de são Paulo Diretoria de publicidade Agrícola. 1939.

LAKOFF, George. Women, Fire, and Dangerous What Categories Reveal about the Mind. Chicago/London:The University of Chicago Press.1990

. The Contemporary Theory of Metaphor. In: Ortony. A.

(ed.) Metaphor and Thought. New York: Cambridge University Press. 1993. P. 202-251.

; JOHNSON, Mark. Metaphor we live by. Chicago/London: The University of Chicago Press.1980.

LEMOS BARBOSA, Padre Antonio. O vocabulário na língua brasílica. Rio de Janeiro: Ministério da Educação e Saúde, 1948, p. 21.

LEVY CARDOSO, Armando . Toponímia brasílica. Rio de Janeiro, Biblioteca do Exército Editora. 1961.

LIMA, Luiz Costa. O Estruturalismo de Lévi-Strauss. Petrópolis: Editora Vozes, 1970.

LINO,Clayton. F. Iporanga: um plano de desenvolvimento urbano e proteção do patrimônio cultural. São Paulo. Monografia de Especialização em Patrimônio Ambiental Urbano, FAU. USP.1978.

- Quilombos do Vale do Ribeira- Levantamentos Arquitetônicos e Fotográficos. 1977/1978

Alto Vale do Ribeira. Arquitetura e Paisagem. São Paulo. Condephaat, 1978.

- Bairro da Serra: Estudo sobre um bairro rural de Iporanga- Vale do Ribeira-SP. Trabalho realizado para a Disciplina Bairros Rurais, ministrado pela Professora Doutora 
Liliana Langará do Departamento de Geografia da FFLCH,USP. 1980. - Iporanga- Notas Históricas. São Paulo. Produzido e Impresso no Instituto Florestal. 1998.

LÉVI-STRAUSS, Claude. O Pensamento Selvagem. Campinas : Editora Papirus, 2009.

. O Totemismo Hoje. Lisboa, Portugal. Perspectivas do homem/edições70, 2003

- Antropologia Estrutural. 2o Edição. Rio de Janeiro. tempo brasileiro. 1970.

LOPES, Edward. Fundamentos de Linguística Contemporânea: São Paulo, Cultrix, 1995.

LYONS, John. Semantics 1. Cambridge: Cambridge University Press, 1991.

MACEDO, Oswaldo. Apiaí: do sertão á civilização: história regional. Apiaí no Alto Ribeira e arredores. São Paulo: Ômega Editora e Distribuidora. 2001

MARQUES, Manuel Eufrásio de Azevedo. Apontamentos, Históricos, Geográficos, Biográficos, Estatísticos e Noticiosos. Tomo I Biblioteca Histórica Paulista. São Paulo: 1953.

- Apontamentos, Históricos, Geográficos, Biográficos, Estatísticos e Noticiosos. Tomo II. Biblioteca Histórica Paulista. São Paulo: 1953.

MURILLO, Edelsvitha Partel. Alto Tietê Producing System: A Toponimic Study. Saarrbrucken, Gemany. VDM VErlag Dr Muller, 2010.

NASCENTES, Antenor. Dicionário Etimológico da Língua Portuguesa. Rio de Janeiro: Francisco Alves, 1932. 
NEGROS DO RIBEIRA : reconhecimento étnico e conquista do território / [editores Tânia Andrade, Carlos Alberto Claro Pereira, Marcia Regina de oliveira Andrade]. - $2^{0}$ ediçãoSão Paulo: ITESP: Páginas e Letras - Editora Gráfica , 2000 - Cadernos do ITESP, 3.

NORBERG-SCHULZ, Christian. Intentions in Architecture.Cambridge: The Massachusetts Institute of Technology. 1968.

. Existence, Space \& Architecture. London: Studio Vista London.1971

Genius Loci. Towards a Phenomenology of Architecture. New York: Rizzoli. 1980.

O'DWYER, Eliane,C. Terra de Quilombos. Identidade étnica e os caminhos do reconhecimento.Tomo. Revista do núcleo de Pós Graduação e Pesquisa em Ciências Universidade Federal de Recife. N 11. Julho/dezembro de 2007.

PAIS, Cidmar Teodoro. Conceitualização, denominação, designação: relações. In: Revista Brasileira de Linguística. V.9, n.1. São Paulo: 1997.p. 221- 239.

- Campos Conceptuais, Campos Lexicais, Campos Semânticos, da Cognição à Semiose.In: Cadernos do CNLF, Ano VI, № 07. Rio de Janeiro: 2002. p. 72-85.

PALMER, Frank.R. Semantics. New York/London: Cambridge University. 1984.

PIERCE, Charles Sanders. Semiótica e Filosofia. São Paulo: Cultrix: 1975. Contexto, 2004.

POTTIER, Bernard. Linguística Geral: teoria e descrição (Tradução e adaptação portuguesa de Waldomiro Macedo). Rio de Janeiro: Presença, Universidade Santa Úrsula, 1978.

PRADO, Cecília. Peabiru a Trilha Misteriosa. Problemas Brasileiros.Arte do Improviso. Edição de setembro de 2011, n. 407. SESC São Paulo. Disponível em 
http://www.sescsp.org.br/online/artigo/5670 PEABIRU+A+T RILHA+MISTERIOSA\#/tagcloud=lista Acessado em abril de 2013.

PREZIA, Benedito A. Os indígenas do Planalto Paulista, São Paulo, Humanitas.2010.

SAMPAIO, Teodoro. O Tupi na Geografia Nacional. 5. ed. São Paulo: Companhia Editora Nacional. 1987.

SANCHES, Luis Henrique. Patrimônio Mineiro do Vale do Ribeira. Texto Preparado para a Jornada Iberoamericana sobre el Patrimônio Geológico Minero. Santa Cruz de La Sierra, Bolívia, fevereiro de 2002.

SANO, Nara Nanae. Estudo Comparado da Gestão das Visitações do nos Parques Estaduais Turístico do Alto Ribeira, Petar, e Intervales, Pei. Dissertação de Mestrado apresentada ao Departamento de Geografia da Faculdade de Filosofia Letras e Ciências Humanas da Universidade de São Paulo. 2007.

SANTOS, Joaquim Justino. Memórias de JJ, Um Caboclo Espeleólogo. São Paulo. All Print Editora, 2010

SANTOS, M. Walburga. Saberes da Terra: o lúdico em Bombas, uma comunidade quilombola ( estudo de caso etnográfico). Tese de Doutorado apresentada na Faculdade de Educação da Universidade de São Paulo.2010

SANTOS, Milton. A Natureza do Espaço. São Paulo: Edusp, 2006. . A Urbanização Brasileira. São Paulo: Edusp, 2005. . Metamorfoses do Espaço Habitado. São Paulo: Hucitec, 1988.

SAPIR, Edward. A Linguagem. São Paulo: Perspectiva, 1980.

SAUSSURE, Ferdinand de. Curso de Linguística Geral. São Paulo: Cultrix, 2004.

SEARLE, John R. Metaphor. In: Ortony. A. (ed.) Metaphor and Thought. New York: Cambridge University Press,1979,pp.92123. 
SILVEIRA, Pedro Castelo Branco. Povo da Terra, Terra do Parque: Presença humana e conservação de florestas no Parque Estadual Turístico do Alto Ribeira, SP. Dissertação de Mestrado apresentada ao Departamento de Antropologia do Instituto de Filosofia e Ciências Humanas da Universidade Estadual de Campinas. 2001.

Relatório Técnico-Científico sobre os Remanescentes da Comunidade de Quilombo de Bomba, Iporanga-SP. ITESP. 2003.

SOCIEDADE BRASILEIRA DE ESPELEOLOGIA, SBE. As Maiores Cavernas do Brasil. Disponível em http://www.sbe.com.br/cnc/CavernasBW/RegioesBrasil Acessado em janeiro de 2013

STADEN. Hans. Duas Viagens ao Brasil: primeiros registros sobre o Brasil. Porto Alegre . L\&PM, 2009.

STUCCHI, Deborah. Percursos em dupla jornada: o papel da perícia antropológica e dos antropólogos nas políticas de reconhecimento de direitos. Tese de Doutorado em Ciências Sociais apresentada ao Departamento de Antropologia do Instituto de Filosofia e Ciências Humanas da Universidade de Campinas. 2005

STEWART, George R. A. A classification of place names. In: Names. Berkeley, V. II (1). Março de 1954.

TAUNAY, Affonso de E. Estudos de História Paulista. São Paulo: Diário Official, 1927.

TUAN, Yi-Fu. Espaço e lugar: a perspectiva da experiência. São Paulo: Difel, 1983.

ULLMANN, Stephen. Semântica. Uma Introdução à Ciência do Significado. Lisboa: Fundação Calouste Gulbenkian, 1973.

VICO, Giambasttista. Princípios de (uma) Ciência Nova (acerca da natureza comum das nações). São Paulo: Abril Cultural. Editor Victor Civita, 1974. 
YOUNG, Ernst W. Esboço Histórico da Fundação da cidade de Iguape. Revista do Instituto Histórico e Geográfico de São Paulo, vol. II, p. 49-151, 1896. Disponível em http://my.opera.com/perfeito/albums/show.dml?id=674490 Acessado em janeiro de 2013. 
Anexo A : Plano de Manejo do Parque Estadual Turístico do Alto Ribeira-Petar Ocupação Humana do Interior e do Entorno Instituto Florestal e Secretaria do Meio Ambiente do Estado de São Paulo.

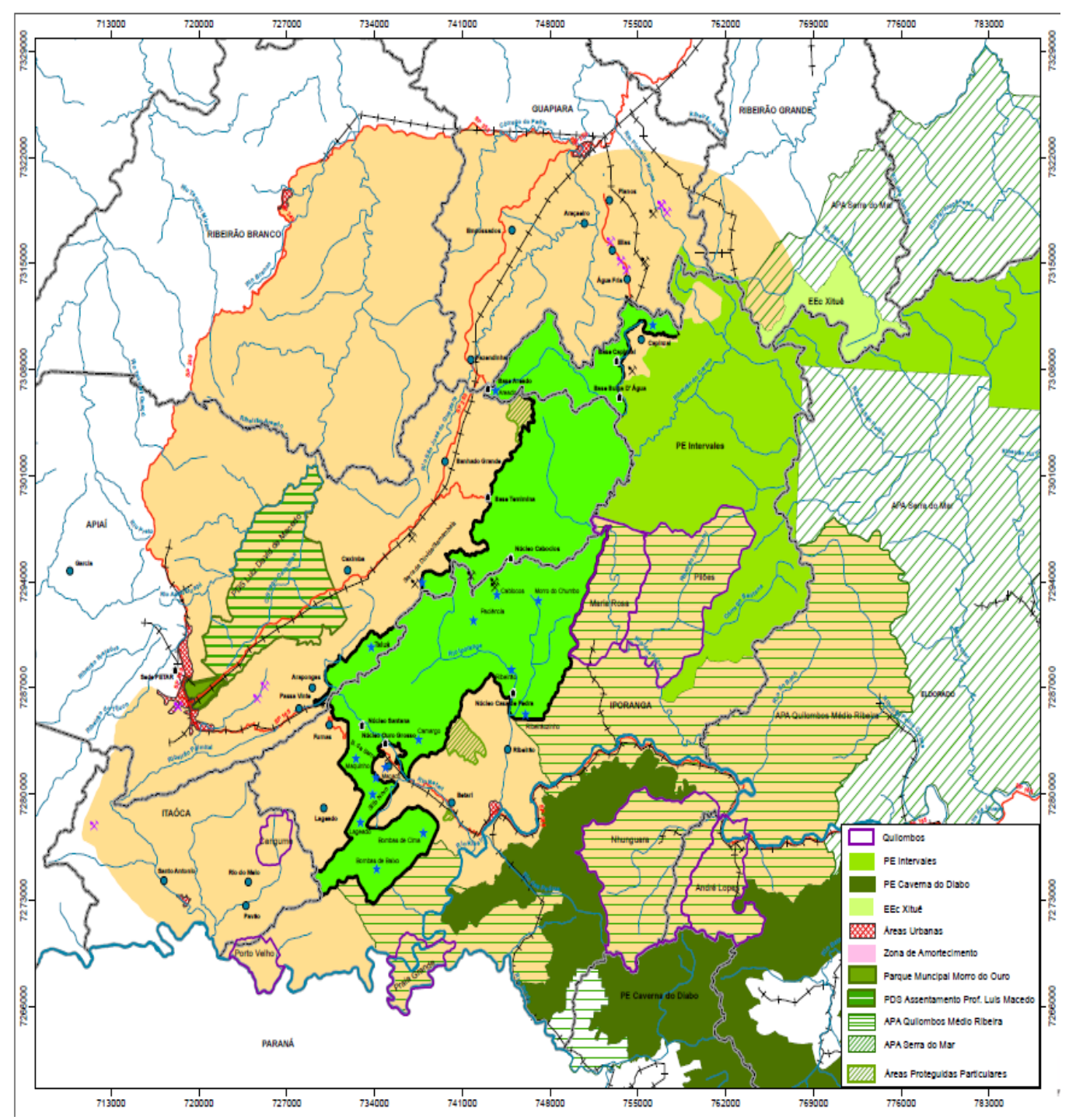

